MARIANNE ORLANDINI KLEIN

\title{
Dieta hiperlipídica materna: influências sobre o comportamento maternal e o desenvolvimento da prole
}

Tese apresentada ao Programa de Pós-graduação em Farmacologia do Instituto de Ciências Biomédicas da Universidade de São Paulo, para obtenção do Título de Doutor em Ciências. 


\section{Dieta hiperlipídica materna: influências sobre o comportamento maternal e o desenvolvimento da prole}

Tese apresentada ao Programa de Pósgraduação em Farmacologia do Instituto de Ciências Biomédicas da Universidade de São Paulo, para obtenção do Título de Doutor em Ciências.

Área de concentração: Farmacologia

Orientador: Prof. Dr. Luciano Freitas Felicio

Versão original 
DADOS DE CATALOGAÇÃO NA PUBLICAÇÃO (CIP)

Serviço de Biblioteca e Informação Biomédica do

Instituto de Ciências Biomédicas da Universidade de São Paulo

(C) reprodução total

Klein, Marianne Orlandini.

Dieta hiperlipídica materna:influências sobre o comportamento maternal e o desenvolvimento da prole / Marianne Orlandini Klein. -São Paulo, 2016.

Orientador: Luciano Freitas Felício.

Tese (Doutorado) - Universidade de São Paulo. Instituto de Ciências Biomédicas. Departamento de Farmacologia. Área de concentração: Farmacologia. Linha de pesquisa: Neurobiologia dos comportamentos reprodutivos.

Versão do título para o inglês: Maternal high fat diet:influences on maternal behavior and offspring development.

1. Comportamento materno animal 2. Desenvolvimento animal 3. Gorduras na dieta 4. Ingestão 5. influências sobre o comportamento maternal e o desenvolvimento da prole 6. I. Luciano Freitas Felício II. Universidade de São Paulo. Instituto de Ciêncais Biomédicas. Programa de Pós-Graduação em Farmacologia III. Título. 


\section{UNIVERSIDADE DE SÃO PAULO \\ INSTITUTO DE CIÊNCIAS BIOMÉDICAS}

Candidato(a): $\quad$ Marianne Orlandini Klein.

Título da Tese: $\quad$ Dieta hiperlipídica materna: influências sobre o comportamento maternal e o desenvolvimento da prole.

Orientador(a): $\quad$ Luciano Freitas Felício.

A Comissão Julgadora dos trabalhos de Defesa da Tese de Doutorado, em sessão pública realizada a ..................., considerou
( ) Aprovado(a)
( ) Reprovado(a)

Examinador(a): Assinatura: .

Nome:

Instituição:

Examinador(a): Assinatura:

Nome:

Instituição:

Examinador(a): Assinatura:

Nome:

Instituição:

Examinador(a): Assinatura:

Nome:

Instituição:

Presidente: Assinatura:

Nome:

Instituição: 


\section{Certificado}

Certificamos que o protocolo registrado sob no 135 nas fls. 135 do livro 02 para uso de animais em experimentação, sob a responsabilidade do Prof(a) Dr(a)) Luciano de Freitas Felicio, Coordenador (a) da Linha de pesquisa "Dieta hiperlipidica materna: efeitos sobre o comportamento maternal e desenvolvimento da prole" do qual participam o(s) aluno(s), especialista em laboratório Marianne Orlandini Klein, está de acordo com os Princípios Éticos de Experimentação Animal adotado pela Sociedade Brasileira de Ciência de Animais de Laboratório (SBCAL) e foi aprovado pela COMISSÃO DE ÉTICA NO USO DE ANIMAIS (CEUA) em $\mathbf{0 5 . 1 0 . 2 0 1 2 , ~ c o m ~}$ validade de 4 anos.

São Paulo, 16 de outubro de 2012.
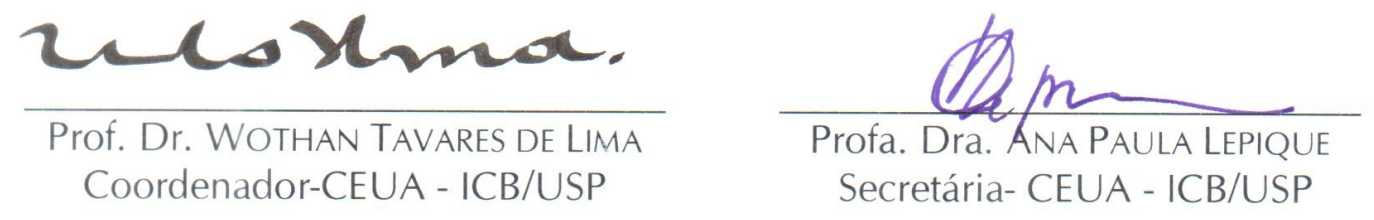


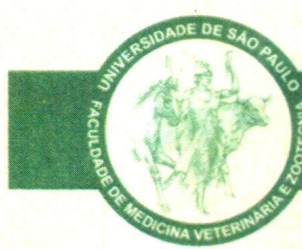

FACULDADE DE MEDICINA VETERINÁRIA E ZOOTECNIA
UNIVERSIDADE DE SÃO PAULO

Comissão de Ética no uso de animais

\section{CERTIFICADO}

Certificamos que o Projeto intitulado "Dieta hiperlipídica materna: influências sobre o comportamento maternal e o desenvolvimento da prole", protocolado sob o $\mathrm{n}^{\circ} 2848 / 2012$, utilizando 80 (oitenta) ratos, sob a responsabilidade do(a) Prof. Dr. Luciano Freitas Felício, aluna Marianne Orlandini Klein, está de acordo com os princípios éticos de experimentação animal da "Comissão de Ética no uso de animais" da Faculdade de Medicina Veterinária e Zootecnia da Universidade de São Paulo e foi aprovado em reunião de 12/12/ 2012.

We certify that the Research "Maternal high-fat diet: influences on maternal behavior offspring dvelopment", protocol number 2848/2012, utilizing 80 (eighty) rats, under the responsibility Prof. Dr. Luciano Freitas Felício, aluna Marianne Orlandini Klein, agree with Ethical Principles in Animal Research adopted by "Ethic Committee in the use of animals" of the School of Veterinary Medicine and Animal Science of University of São Paulo and was approved in the meeting of day $12 / 12 / 2012$.

São Paulo, 17 de dezembro de 2012.

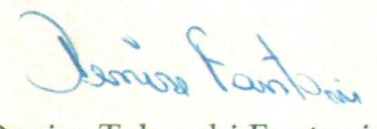

Denise Tabacchi Fantoni

Presidente 
A meus amados pais, Luiz Alberto e Sandra, minha fonte de apoio sem o qual nada seria possível. Amo vocês, eternamente! 


\section{AGRADECIMENTOS}

A Deus, por ter me dado saúde e força para perseverar em meu sonho.

A meus pais, que mais uma vez apoiaram sem hesitar minhas escolhas. Por me darem todo o amor, suporte e educação necessários para que eu me tornasse a pessoa que sou hoje. Por serem meus grandes incentivadores, emocionalmente e financeiramente, e por acreditarem em mim sempre com muito orgulho, independente do caminho que eu escolhesse. Tudo o que eu disser nunca será suficiente para expressar a gratidão e o amor imenso que sinto por vocês. Muitíssimo obrigada!

A meus irmãos, Vitor e Gabriel, por alegrarem meus dias e compartilharem comigo todos os momentos da nossa abençoada família. Por entenderem minhas ausências e sempre me receberem com muito carinho quando eu retornava para casa. Por sempre atenderem meus pedidos de silêncio e esperar minhas intermináveis horas no computador nesses últimos meses. Muito obrigada, amo vocês!

A meu namorado, Marcos Vinicius, pela paciência e compreensão que tem comigo. Por ser um excelente amigo, por saber me ouvir e me mostrar quando estou errada. Por esperar o meu retorno, que demorou ainda mais desta vez, mas sempre apoiando as minhas decisões, independente em que parte do mundo eu estivesse. Você foi essencial para que eu conquistasse meu sonho. Muito obrigada por estar comigo em todas as etapas. Te amo.

Ao meu orientador, Prof. Dr. Luciano Freitas Felicio, por acreditar em mim e me dar todo o apoio necessário. Por todos os ensinamentos científicos e por me mostrar que não importa a situação, sempre podemos agir com educação e sabedoria. Foram 6 anos, desde o ingresso no mestrado, muito prazerosos em seu laboratório. Obrigada!

A Prof. ${ }^{a}$ Dr. ${ }^{a}$ Ana Carolina Inhasz Kiss, por ser minha co-orientadora e também grande amiga. Obrigada por todos os ensinamentos e pelos momentos de descontração não científicos. Quero ser sua aluna preferida para sempre! 
À Carla Nappo Tobaruela, pela amizade sincera e auxílio com meus experimentos. As várias horas no biotério e os almoços na copa eram muito melhores com sua companhia. Obrigada por estar presente sempre que precisei e por permitir-me presenciar o seu amor pelos animais.

À técnica Magali Caetano, por não medir esforços para me auxiliar, incluindo aos finais de semana, deixando meus dias no laboratório mais divertidos. Obrigada pela parceria e amizade!

À Julieta, Julie, Renata, Regina e Luana pela companhia e risadas no laboratório, e por terem me socorrido algumas vezes quando eu me sobrecarregava com os experimentos.

Aos funcionários do biotério do Departamento de Patologia da Faculdade de Medicina Veterinária e Zootecnia da USP, por toda a paciência e auxílio no cuidado com os animais.

À amiga Evelyn Fantozzi e ao Prof. Dr. Wothan Tavares de Lima, pelo auxílio nas dosagens bioquímicas e hormonais.

Ao meu supervisor de estágio no exterior, Prof. Dr. Alfonso Abizaid, por ter me acolhido de braços abertos e ter confiado em mim na condução de experimentos em seu laboratório. Obrigada por todos os ensinamentos e momentos de descontração. Thank very much Alfie, you are the best!

Aos meus amigos e colegas de laboratório na Carleton University Rebecca, Lindsay, Su, Alex, Harry, Rim, Sam, Trevor e Martin por tudo que me ensinaram e por permitirem minha rápida inclusão no laboratório. Thank you all for being so special in my stay in Canada!

À Prof. ${ }^{a}$ Dr. ${ }^{a}$ Elizabeth Teodorov pelo auxílio no desenvolvimento das técnicas de biologia molecular. 
À Fundação de Amparo a Pesquisa do Estado de São Paulo (FAPESP), pela concessão de bolsas de auxílio financeiro para desenvolvimento do Doutorado no Brasil e no exterior (Processos 2012/06774-0 e 2014/06980-0).

A todas as pessoas do Departamento de Patologia da Faculdade de Medicina Veterinária e Zootecnia e do Departamento de Farmacologia do Instituto de Ciências Biomédicas da Universidade São Paulo que me auxiliaram durante o desenvolvimento deste estudo.

A todos que de alguma maneira foram importantes e participaram da execução desse trabalho. 
"Saber muito não lhe torna inteligente. A inteligência se traduz na forma que você recolhe, julga, maneja e, sobretudo, onde e como aplica esta informação." 


\section{RESUMO}

Klein MO. Dieta hiperlipídica materna: influências sobre o comportamento maternal e o desenvolvimento da prole. [Tese (Doutorado em Farmacologia)]. São Paulo: Instituto de Ciências Biomédicas, Universidade de São Paulo; 2016.

A alimentação materna rica em lipídios pode causar prejuízos no desenvolvimento e vida adulta dos descendentes, elevando o risco de desenvolver alterações metabólicas e obesidade. Este tipo de dieta também parece alterar a sinalização central por opióides. Porém, os estudos realizados a fim de investigar a influência da dieta hiperlipídica materna sobre o comportamento materno e o desenvolvimento da prole não são conclusivos. Deste modo, este estudo investigou a influência da dieta rica em lipídeos sobre a interação mãe-filhote e os efeitos imediatos e tardios sobre a prole, relacionando-os ao sistema opióide. Ratas foram divididas em dois grupos (geração $\left.\mathrm{F}_{0}\right)$ : grupo HF, alimentado com dieta hiperlipídica ( $45 \% \mathrm{kcal}$ de lipídeos) do dia 0 de prenhez até o desmame (dia pós-natal (DPN) 21); e grupo controle (C), que recebeu dieta padrão. No desmame, cada ninhada (geração $F_{1}$ ) foi dividida em 2 subgrupos: metade permaneceu com a mesma dieta da mãe, e a outra metade passou a receber dieta oposta daquela oferecida à mãe, resultando em 4 grupos experimentais (CC controle-controle; CHF controle-hiperlipídica; HFC hiperlipídicacontrole; HFHF hiperlipídica-hiperlipídica). No DPN85, as fêmeas $F_{1}$ foram acasaladas. Em ambas as gerações, alterações metabólicas foram avaliadas por meio de testes de tolerância à insulina, testes de tolerância à glicose e análises bioquímicas. O comportamento maternal, com e sem intervenções prévias, foi avaliado no DPN5 e DPN10. Os animais tiveram o consumo calórico e o peso corporal monitorados durante todo o experimento. No DPN21, as mães sofreram eutanásia e o seu hipotálamo foi coletado para avaliação da expressão dos receptores opióides $\mu, \mathrm{k}$ e $\delta$. Os machos adultos $\mathrm{F}_{1}$ tiveram os comportamentos de ansiedade e sexual avaliados. Em outro experimento, foi avaliada a expressão gênica hipotalâmica de fatores de transcrição neurais e de peptídios que controlam a ingestão alimentar e o balanço energético em fetos de mães alimentadas com dieta hiperlipídica durante a gestação. As mães HF apresentaram intolerância à glicose durante a lactação, e as mães dos grupos HFHF e CHF apresentaram níveis elevados de colesterol, LDL-colesterol e reduzidos níveis de leptina. As mães de ambas as gerações com ingestão de dieta hiperlipídica apresentaram ganho de peso reduzido sem apresentar diferenças no consumo calórico. Essas mães também apresentaram menor número de ejeções de leite e maior intervalo entre as ejeções. Todas as mães que receberam dieta hiperlipídica em algum momento da vida apresentaram níveis elevados de expressão dos opióides comparados ao controle. Os machos adultos não apresentaram alterações no comportamento de ansiedade, porém houve uma tendência ao prejuízo do comportamento sexual nos machos alimentados com dieta hiperlipídica. O hipotálamo dos fetos de mães high-fat no $18^{\circ}$ dia de gestação apresentou maior expressão gênica de proopiomelanocortina (POMC) e neuropeptídeo Y (NPY), porém a expressão dos fatores de transcrição não estava alterada. Portanto, o consumo de dieta hiperlipídica materna causou alterações metabólicas, comportamentais e de expressão gênica na mãe e nos descendentes, mesmo que esses animais não tenham se tornado obesos.

Palavras-chave: Alta ingestão de gordura. Comportamento materno. Ejeção de leite. Estudo transgeracional. Opióides. Hipotálamo. Ingestão alimentar. 


\begin{abstract}
Klein MO. Maternal high fat diet: influences on maternal behavior and offspring development. [Doctoral thesis (Pharmacology)]. São Paulo: Instituto de Ciências Biomédicas, Universidade de São Paulo; 2016.
\end{abstract}

A maternal diet high in fat may impair offspring development and adulthood, increasing the risk to develop metabolic alterations and obesity. This kind of diet also seems to modify the opioids central signaling. However, studies investigating maternal high fat diet influences on maternal behavior and offspring development are inconclusive. Thus, this study aimed to evaluate the influences of a diet high in fat on mother-pup interaction and its early and late effects in the offspring, connecting them to the opioid system. Female rats were assigned to ( $F_{0}$ generation): HF group fed a high fat diet ( $45 \% \mathrm{kcal}$ from fat) from gestation day 0 until weaning (post-natal day (PND) 21); C group that received control diet (standard chow). At weaning, each litter was assigned to either subgroup: half of the litter was fed the same diet than the mother was, and the other half was fed a different diet from that the mother was being fed, leading to 4 experimental groups (CC control-control; CHF control-high fat; HFC high fat-control; HFHF high fat-high fat). At PND85, $\mathrm{F}_{1}$ females were mated. In both generations, metabolic alterations were assessed through insulin tolerance tests, glucose tolerance tests and biochemical analysis. Maternal behavior with or without previous interventions was evaluated at PND5 and PND10. Animals had their food intake and body weight followed during the whole experiment. At PND21, dams were killed and their hypothalamus were collected to measure $\mu, \mathrm{k}$ e $\delta$ opioid receptors expression. $F_{1}$ adult males had their anxiety-like and sexual behaviors assessed. In another experiment, the hypothalamic gene expression of neural transcription factors and peptides that control food intake and energy balance was evaluated in fetuses from dams fed a diet high in fat during pregnancy. HF mothers were glucose intolerants in lactation, and HFHF and CHF dams showed high levels of cholesterol, LDL-cholesterol and decreased levels of leptin. Lactating females in both generations eating high fat diet had lower body weight but the caloric intake was the same compared to control groups. These dams also presented a smaller number of milk ejection reflexes and bigger milk ejection intervals. All the mothers that were fed high fat diet in any period of their lives showed higher levels of opioid receptors expression than control. Adult males did not present impaired anxiety-like behavior though high fat fed animals had a tendency to show decreased sexual behavior. The hypothalamus from the fetuses at day 18 of pregnancy from high-fat dams showed higher gene expression of proopiomelanocortin (POMC) and neuropeptide Y (NPY), however the transcription factors expression was not altered. Therefore, maternal high fat intake promoted metabolic, behavioral and gene expression alterations in the mother and her offspring, even though these animals had not become obese.

Keywords: High fat intake. Maternal behavior. Milk ejection. Transgenerational study. Opioids. Hypothalamus. Food intake. 


\section{LISTA DE ILUSTRAÇÕES}

Figura 1 - Esquema representativo das análises feitas com as mães e os filhotes..36 Figura 2 - Esquema representativo da dieta administrada aos animais $F_{1}$ após o desmame.

Figura 3 - Acompanhamento do peso corporal absoluto $(\mathrm{g})$ das mães geração $F_{0}$ durante a gestação. 60

Figura 4 - Acompanhamento da ingestão em $\mathrm{kcal} / \mathrm{Kg}$ de peso corporal durante a gestação das mães $F_{0}$. 60

Figura 5 - Níveis glicêmicos nos dias $0,7,14$ e 21 de gestação das mães $F_{0}$ 60

Figura 6 - Teste de tolerância a insulina (TTI), teste de tolerância à glicose oral (TTOG) e área sob a curva do TTOG dos realizados durante a gestação das mães $\mathrm{F}_{0}$

Figura 7 - Acompanhamento do peso corporal das mães da geração $F_{0}$ durante a lactação

Figura 8 - Acompanhamento da ingestão alimentar das lactantes da geração $F_{0} \ldots . .62$ Figura 9 - Teste de tolerância à insulina (TTI), teste de tolerância oral à glicose (TTOG) e área sob a curva do TTOG das lactantes da geração $F_{0}$ 63

Figura 10 - Duração da prenhez, número de filhotes e proporção de machos e fêmeas nas mães $F_{0}$

Figura 11 - Latência para busca do $1^{\circ}, 5^{\circ}$ e $8^{\circ}$ filhote nos testes de comportamento materno no DPN5 e 10 das mães da geração $F_{0}$

Figura $12-\Delta$ de variação de latência para a busca do $1^{\circ}, 5^{\circ}$ e $8^{\circ}$ filhotes das mães da geração $F_{0}$

Figura 13 - Parâmetros de número de buscas aos filhotes (A), tempo gasto realizando selfgrooming $(B)$, tempo gasto agrupando os filhotes $(C)$ e tempo total lambendo os filhotes (D).

Figura 14 - Tempo gasto pelas mães da geração $F_{0}$ sem cuidados destinados aos filhotes (fora do ninho) e tempo gasto construindo o ninho.

Figura 15 - Tempo gasto pelas mães da geração F0 amamentando 4 ou menos filhotes (A), 5 ou mais filhotes (B), tempo gasto em crouching (C) e percentual de mães que realizaram CMT (D).

Figura 16 - Parâmetros de comportamento materno avaliados durante 6 horas consecutivas nas lactantes da geração $F_{0}$. 
Figura 17 - Selfgrooming, grooming dos filhotes, tempo amamentando em cifose e em outras posições - mães $F_{0}$.

Figura 18 - Parâmetros da ejeção de leite avaliados nos grupo C e HF $\left(F_{0}\right) \ldots \ldots \ldots . . .70$

Figura 19 - Níveis de insulina e leptina séricos nas lactantes $F_{0} \ldots \ldots \ldots \ldots \ldots \ldots \ldots \ldots . . . \ldots 1$

Figura 20 - Análise da expressão dos genes Oprm1, Oprk1 e Oprd1 e das proteínas MOR, KOR e DOR nas mães da geração $F_{0}$ .72

Figura 21 - Classificação dos neonatos de acordo com o peso ao nascimento.......73

Figura 22 -Peso da ninhada durante a lactação - Geração $F_{1} \ldots \ldots \ldots \ldots \ldots \ldots \ldots \ldots \ldots . . \ldots \ldots$

Figura 23 - Parâmetros de desenvolvimento físico da geração $F_{1}$. .75

Figura 24 - Parâmetros de desenvolvimento sexual dos animais da geração $F_{1} \ldots . .76$

Figura 25 - Peso corporal dos machos (A) e fêmeas (B) do DPN 21 ao 85. .76

Figura 26 - Ingestão alimentar semanal dos machos (A) e das fêmeas (B) da semana 4 a 10 de vida. .77

Figura 27 - Dosagens séricas de insulina e leptina em machos e fêmeas adultos...82

Figura 28 - Teste de preferência à dieta hiperlipídica

Figura 29 - Teste de preferencia à sacarose .83

Figura 30 - Peso corporal durante a gestação das mães da geração $F_{1}$ .85

Figura 31 - Ingestão alimentar durante a gestação das mães $F_{1}$ .85

Figura 32 - Glicemia nos dias 0, 7, 14 e 21 de gestação das mães da geração $F_{1} . .86$ Figura 33 - Teste de tolerância à insulina (TTI), teste de tolerância oral à glicose (TTOG), e área sob a curva do TTG das fêmeas gestantes da geração $F_{1}$ 87

Figura 34 - Ganho de peso corporal das fêmeas lactantes da geração $F_{1}$ .87

Figura 35 - Acompanhamento da ingestão alimentar das lactantes $F_{1}$ .88

Figura 36 - Teste de tolerância à insulina (TTI), teste de tolerância oral à glicose (TTOG) e área sob a curva do TTOG (AUC) das lactantes da geração $F_{1}$ .88

Figura 37 - Duração da prenhez, número de filhotes e proporção de machos e fêmeas nas mães $F_{1}$

Figura 38 - Latência para busca do $1^{\circ}(\mathrm{A}), 5^{\circ}(\mathrm{B})$ e $8^{\circ}(\mathrm{C})$ filhotes no DPN 5 e 10 pelas mães da geração $F_{1}$ .90

Figura 39 - Parâmetros de número de buscas aos filhotes (A), tempo gasto realizando selfgrooming das mamas $(B)$, tempo dispensado agrupando os filhotes (C) e tempo gasto lambendo (grooming) os filhotes (D) nos DPN 5 e 10 nas mães da geração $F_{1}$ 
Figura 40 - Tempo que as mães da geração $F_{1}$ ficaram fora do ninho, longe dos filhotes (A) e tempo dispensado construindo o ninho (B).

Figura 41 - Parâmetros de amamentação de 4 ou menos filhotes (A), 5 ou mais filhotes (B), amamentação dos filhotes em cifose fisiológica (crouching - C) e comportamento materno total (CMT) nas mães da geração $F_{1}$

Figura 42 - Parâmetros de comportamento materno analisados por 6 horas $-F_{1} \ldots 93$ Figura 43 - Selfgrooming, grooming dos filhotes e amamentação com e sem cifose nas mães da geração $F_{1}$ 94

Figura 44 - Parâmetros de tempo de amamentação e ejeções de leite - $F_{1}$ .95

Figura 45 - Dosagem sérica de insulina $(A)$ e leptina $(B)$ nas mães $F_{1}$ no DPN21 ...96 Figura 46 - Análise da expressão dos genes Oprm1, Oprk1 e Oprd1 por qPCR e da expressão protéica MOR, KOR e DOR por Western Blotting nas mães da geração $F_{1}$

Figura 47 - Classificação dos neonatos de acordo com o peso ao nascimento.......99

Figura 48 - Ganho de peso da ninhada da geração $F_{2}$ durante a lactação..............100

Figura 49 - Parâmetros de desenvolvimento físico dos filhotes na geração $F_{2} \ldots . . .102$

Figura 50 - Teste de labirinto em cruz elevado - Machos $F_{1}$ 103

Figura 51 - Parâmetros avaliados no teste de comportamento sexual de machos. 104

Figura 52 - Peso corporal, do tecido adiposo e percentual de gordura corporal nos machos $\mathrm{F}_{1}$ 105

Figura 53 - Expressão de genes que atuam no desenvolvimento hipotalâmico durante a gestação.

Figura 54 - Expressão dos genes envolvidos com o controle da ingestão alimentar. 108

Figura 55 - Expressão gênica do PC1, PC2, SOCS3 e MC4R 109

Figura 56 - Neurônios POMC no núcleo arqueado do hipotálamo no DG18. 109 


\section{LISTA DE TABELAS}

Tabela 1 - Sequência dos primers utilizados.

Tabela 2 - Parâmetros bioquímicos das mães (geração $F_{0}$ ) no DPN21 - dia do desmame.

Tabela 3 - Peso corporal, dos órgãos, e glicemia de jejum das mães $F_{0}$ após o desmame no DPN21.

Tabela 4 - Peso corporal, comprimento corporal e distância ano-genital dos filhotes machos e fêmeas de cada grupo da geração $F_{1}$

Tabela 5 - Peso corporal, peso do fígado e dos tecidos adiposos retroperitoneal e retrogonadal de machos aos 35 e 70 dias de vida pós-natal.

Tabela 6 - Peso corporal, peso do fígado e dos tecidos adiposos retroperitoneal e retrogonadal em fêmeas no DPN 35 e 70

Tabela 7 - Parâmetros bioquímicos dos machos aos 35 e 70 dias de vida pósnatal.

Tabela 8 - Parâmetros bioquímicos das descendentes fêmeas aos 35 e 70 DPN...81

Tabela 9 - Duração do ciclo estral.

Tabela 10 - Parâmetros bioquímicos das mães (geração $F_{1}$ ) no DPN21 - dia do desmame.

Tabela 11 - Peso corporal e dos órgãos das mães da geração F1 após o desmame no DPN21 .98

Tabela 12 - Peso corporal, comprimento corporal e distância ano-genital dos filhotes machos da geração F2 durante a lactação.

Tabela 13 - Peso corporal, comprimento corporal e distância ano-genital dos filhotes fêmeas da geração F2 durante a lactação. 102

Tabela 14 - Peso do fígado, órgãos do sistema reprodutor e da hipófise machos 106

Tabela 15 - Parâmetros bioquímicos dos machos no DPN120. 106 


\section{SUMÁRIO}

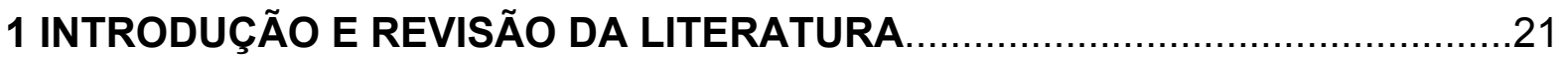

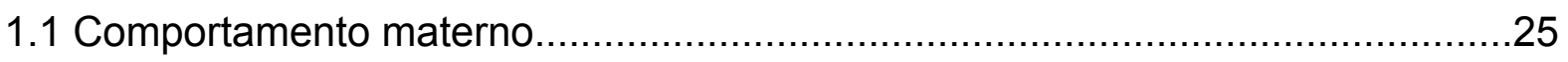

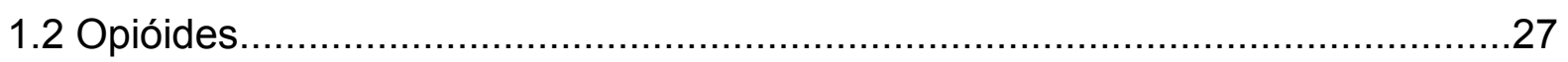

1.3 Fatores de transcrição neurais e a dieta hiperlipídica.....................................29

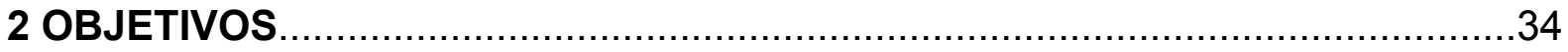

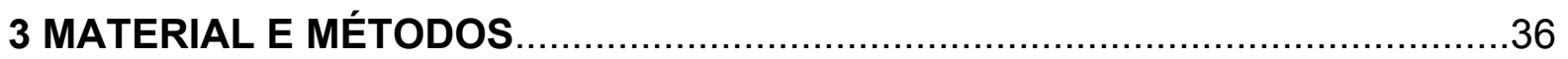

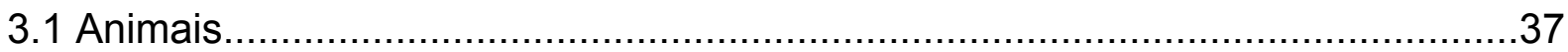

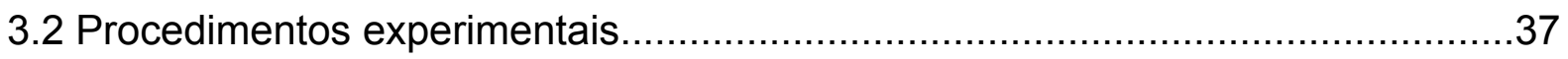

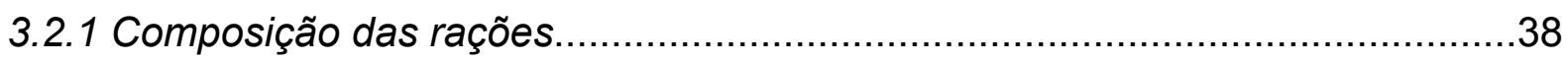

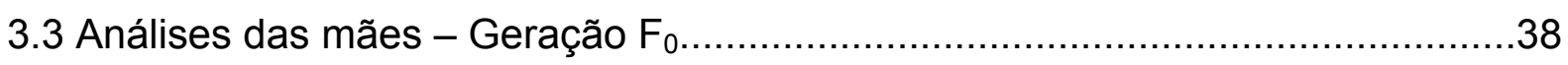

3.3.1 Determinação dos níveis glicêmicos durante a gestação..............................39

3.3.2 Teste de tolerância à insulina..............................................................39

3.3.3 Teste de tolerância oral à glicose .........................................................39

3.3.4 Análises do comportamento materno...................................................40

3.3.4.1 Análise do comportamento materno após a mãe ter sido privada dos

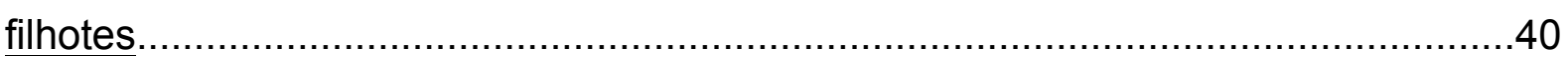

3.3.4.2 Análise do comportamento materno sem intervenção prévia........................41

3.3.5 Análise materna no desmame............................................................41

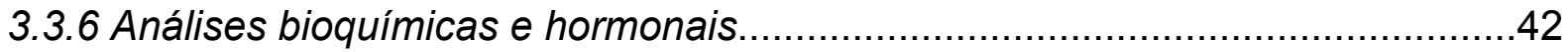

3.3.7 Expressão dos genes Oprm1, Oprk1 e Oprd1 .........................................42

3.3.7.1 Ensaio da transcrição reversa (RT-PCR) ...........................................42

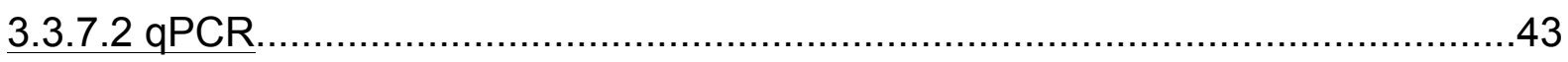

3.3.8 Expressão das proteínas MOR, KOR e DOR por Western Blotting..................44

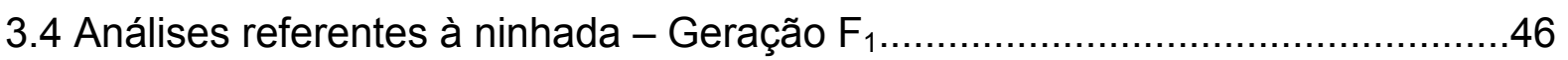

3.4.1 Análise do desenvolvimento físico.......................................................46

3.4.2 Análise do desenvolvimento sexual..........................................................47

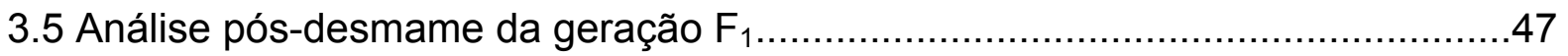

3.5.1 Eutanásia dos filhotes nos DPN35 e 70...............................................48

3.5.2 Teste de preferência à sacarose.......................................................48

3.5.3 Teste de preferência à dieta hiperlipídica................................................49

3.6 Acompanhamento do ciclo estral e acasalamento das fêmeas da geração $F_{1} \ldots .49$

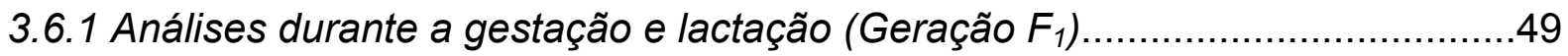


3.6.2 Análise do comportamento materno (Geração $\left.F_{1}\right)$........................................50

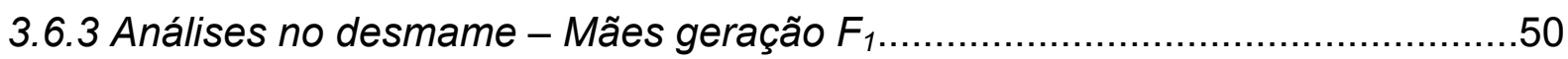

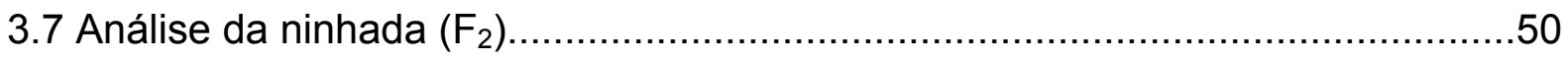

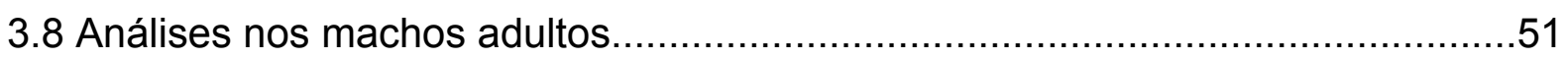

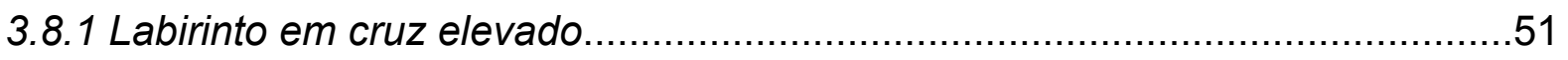

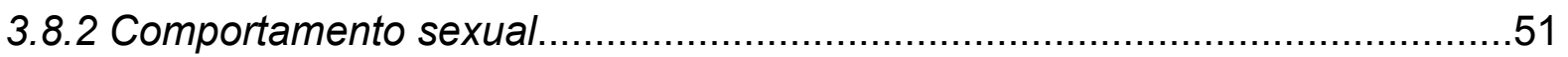

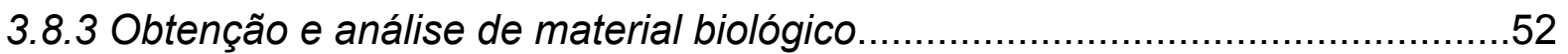

3.9 Expressão gênica de fatores de transcrição neurais durante a gestação.............52

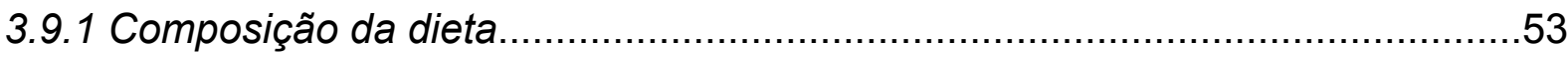

3.9.2 Obtenção e processamento dos encéfalos dos fetos....................................53

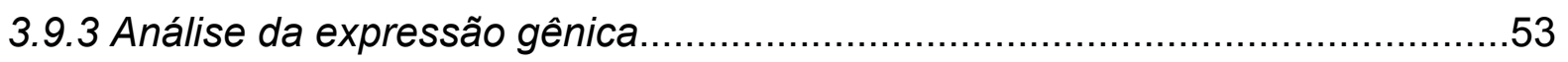

3.9.3.1 Ensaio da transcrição reversa (RT-PCR) ..............................................54

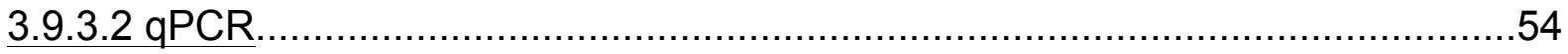

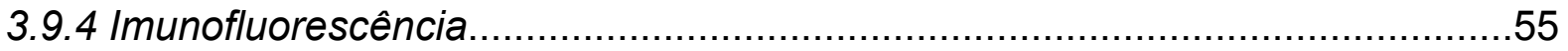

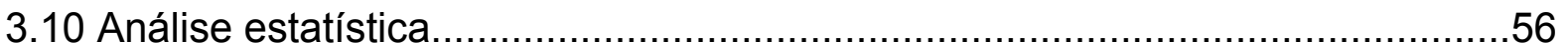

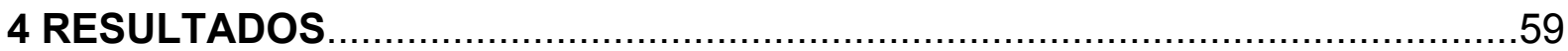

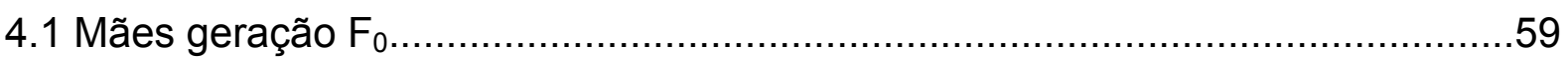

4.1.1 Comportamento materno - Geração Fo..................................................64

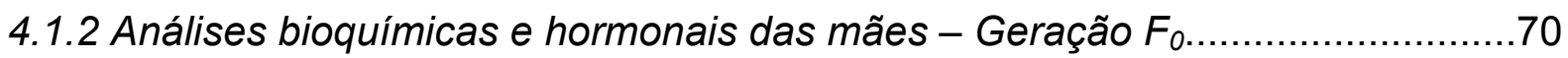

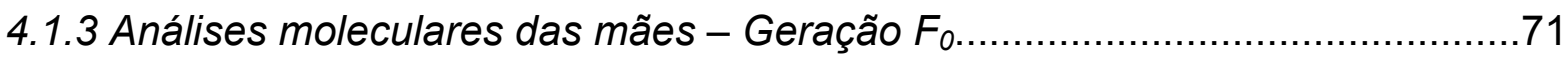

4.1.4 Peso corporal, peso do fígado e do tecido adiposo no DPN21 das mães -

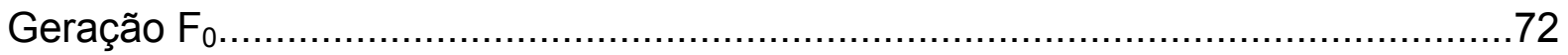

4.2 Parâmetros de desenvolvimento dos filhotes até o DPN70 - Geração $F_{1} \ldots \ldots \ldots . . .73$

4.2.1 Testes de preferência alimentar e à sacarose...............................................82

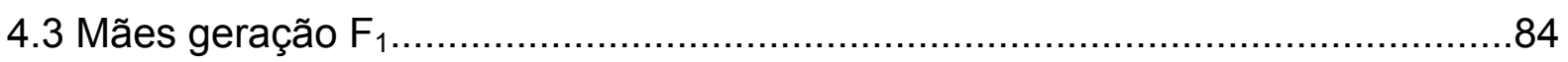

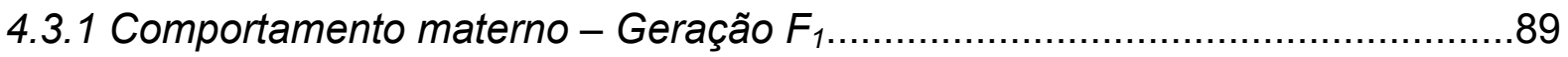

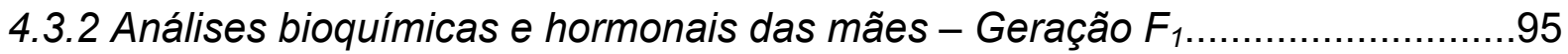

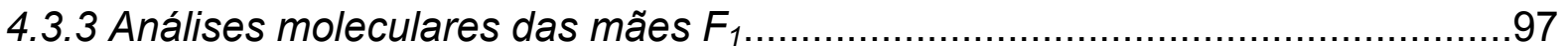

4.3.4 Peso corporal, peso do fígado e do tecido adiposo no DPN21 das mães -

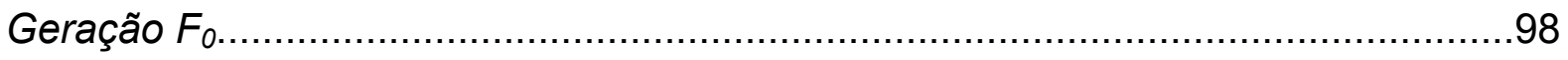

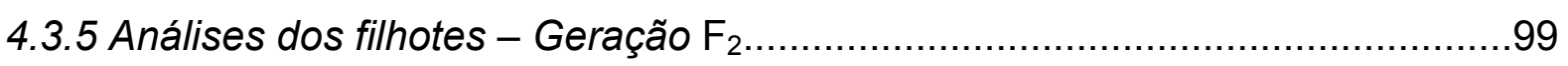

4.4 Análises nos machos da geração $F_{1}$ após o DPN70 ...................................103

4.5 Análise da expressão gênica hipotalâmica durante a gestação.........................106

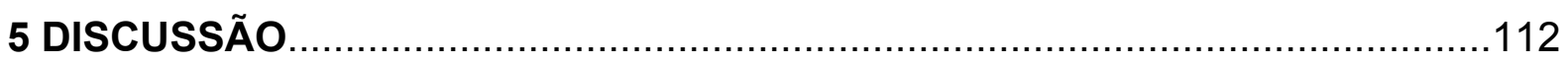




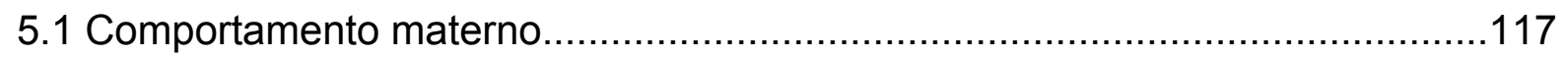

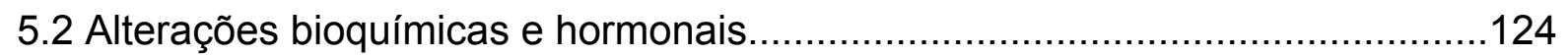

5.3 Testes de preferência e a relação com opióides...........................................126

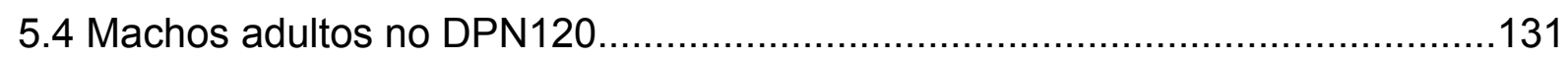

5.5 Expressão gênica dos fatores de transcrição neurais durante a gestação........134

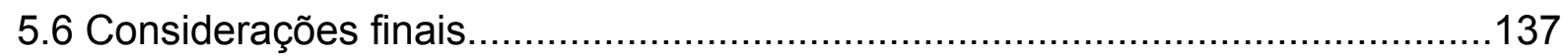

6 CONCLUSÕES

REFERÊNCIAS 
"DA FELICIDADE

Quantas vezes a gente, em busca da ventura,

Procede tal e qual o avozinho infeliz: Em vão, por toda parte, os óculos procura Tendo-os na ponta do nariz!" Mario Quintana

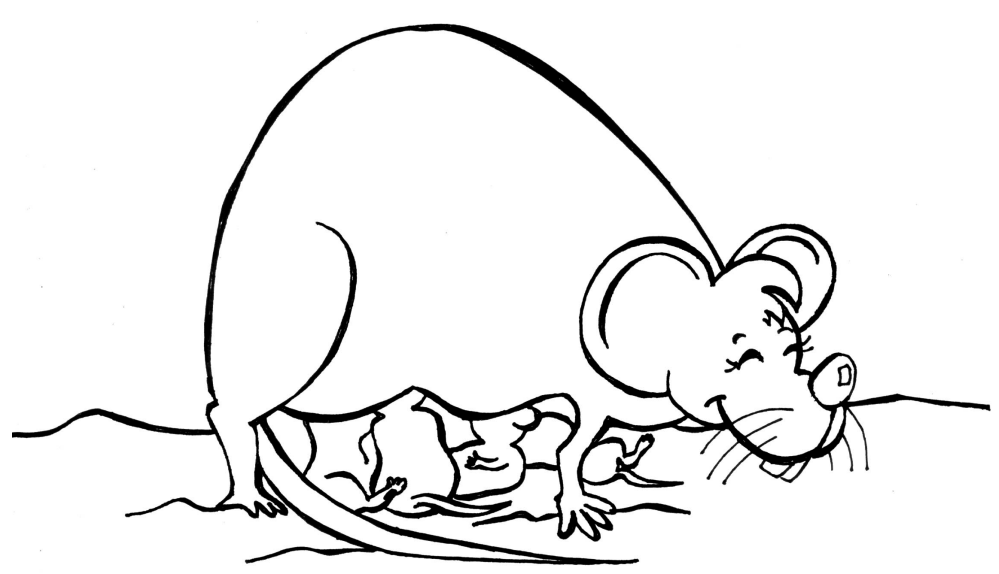


O comportamento alimentar é um ato complexo que é influenciado por múltiplos aspectos tais como o estado fisiológico do indivíduo, fatores hedônicos, e no caso de humanos, até fatores culturais e filosóficos (Gaillard et al., 2008). Atualmente, os lipídeos compõem aproximadamente $40 \%$ das calorias ingeridas nas dietas dos países ocidentais, enquanto que as recomendações nutricionais variam de 5 a 10\% (Gaillard et al., 2008; Tso, Liu; 2004). Assim, esse excesso de ingestão lipídica tem levado ao aumento no número de indivíduos com alterações metabólicas, podendo desenvolver obesidade.

Desde a década de 80 , o número de pessoas obesas mais que dobrou. Atualmente, a maioria da população mundial vive em países em que a as alterações metabólicas e a obesidade causam mais mortes do que a subnutrição (World Health Organization, 2015). Países menos industrializados, os quais anteriormente apresentavam sérios problemas relacionados à subnutrição, têm evidenciado uma transição demográfica do nanismo para a obesidade de crianças e adultos (Gupta et al., 2013). Diante de tais fatos, o assunto tem sido cada vez mais estudado: existem mais de 36 mil artigos científicos publicados sobre a ingestão de dieta hiperlipídica na base de dados do PubMed (National Center for Biotechnology Information, U.S. National Library of Medicine, Bethesda, MD, EUA). Estes estudos tentam elucidar os mecanismos pelos quais o alto consumo lipídico pode levar a desenvolver alterações metabólicas e obesidade, as consequências dessas doenças, e a busca por formas de prevenção mais efetivas e tratamentos mais eficazes.

Muitas crianças são expostas a má nutrição alimentar desde a gestação. Em 2014, 40\% da população mundial de mulheres com mais de 18 anos estava acima do peso (WHO, 2015). Existem evidências de que o consumo alimentar materno em mamíferos pode causar prejuízo na vida adulta dos descendentes. Os riscos envolvem desde um aumento da propensão a desenvolver obesidade, até alterações metabólicas e das funções homeostáticas (Barker, 2002; Poston, 2012; Samuelsson et al., 2008). A nutrição parental é tão importante no desenvolvimento dos filhotes, que até os hábitos paternos podem influenciar esse processo. $\mathrm{Ng}$ et al. (2010) relataram que as ratas de pais alimentados com dieta hiperlipídica possuem alterações na função das células $\beta$-pancreáticas. O número de estudos sobre a importância paterna para o filhote tem crescido recentemente, sugerindo que essa influência pode ser exercida através de cuidados diretos, ou pela transmissão epigenética de efeitos ambientais entre os quais estão a nutrição, estresse e toxinas, 
ou ainda indiretamente ao interferir na qualidade das interações mãe-filhote (Braun, Champagne, 2014). Por outro lado, as interações dos pais e filhos em mamíferos durante a fase inicial da vida são principalmente através da mãe, sendo assim mais estudadas.

Existem muitos modelos animais que visam investigar a influência da nutrição materna sobre os filhotes: injeção intra-fetal de glicose em ovelhas durante o terço final de gestação, injeções gástricas de dieta hiperlipídica líquida em ratos, alimentação a base de dietas hipercalóricas, dietas hiperlipídicas puras ou suplementadas com leite condensado e ainda "junk food" com alto teor de gordura ou açúcar, conhecidas como dieta do tipo cafeteria. Em todos esses modelos de nutrição materna, os efeitos prejudiciais, como hiperfagia, alta adiposidade corporal, elevados níveis de triglicérides, glicemia anormal e sensibilidade reduzida à insulina têm sido observados nos filhotes (Ainge et al., 2011). Fatores genéticos e ambientais têm papel no desenvolvimento de alterações metabólicas, e a dieta é um dos principais fatores ambientais que contribuem para o aparecimento das doenças. Modelos animais de roedores alimentados com dieta hipercalórica composta por elevado teor de açúcar ou lipídeos têm sido muito utilizados para estudos relacionados aos efeitos da nutrição materna sobre os filhotes.

Porém, a maioria dos estudos se concentram em modificações na dieta da mãe a curto prazo, durante a gestação e/ou lactação, resultando em graus variados de alterações fenotípicas (Elahi et al., 2009). Assim, estender para além do desmame o consumo de dieta hiperlipídica no modelo animal a fim de investigar as consequências para os descendentes até que esses se tornem adultos é importante, possibilitando ainda avaliar se há efeitos aditivos da alimentação com alto teor de gordura pelo próprio descendente nesse período, assemelhando-se ao que ocorre em humanos (Elahi et al., 2009).

Existem relações bem estabelecidas entre a nutrição materna durante a prenhez e o desenvolvimento de alterações metabólicas nos filhotes. Há evidências de que a composição corporal materna por si só é um fator predisponente à adiposidade nos filhotes (Sacks et al., 2006). Por outro lado, White et al. (2009) afirmam que a maior adiposidade materna, e não somente o consumo de dieta rica em lipídeos, é necessária para induzir resistência a insulina, hiperleptinemia e maior peso nos descendentes quando adultos (White et al., 2009). Estudos têm sido feitos na tentativa de descobrir os mecanismos que contribuem para a programação dos 
sistemas fisiológicos, uma vez que a teoria da origem fetal das doenças no adulto tem se tornado cada vez mais relevante (Barker, 1995, 1999). Assim, cercear o aparecimento de possíveis doenças metabólicas na fase inicial da vida parece ser um caminho promissor por meio do qual se pode fazer uma tentativa de ajudar a conter a epidemia da obesidade (Alfaradhi, Ozanne, 2011).

Filhotes de ratas alimentadas com dieta hiperlipídica durante a prenhez e lactação apresentam puberdade precoce e são hiperleptinêmicos, hiperinsulinêmicos e obesos quando adultos, independentemente da dieta pós-desmame (Howie et al., 2009; Sloboda et al., 2009). Os descendentes de camundongos submetidos à dieta hiperlipídica apresentaram aumento no peso corporal e na gordura visceral, hipertrofia dos adipócitos e resistência à insulina, sem associação com a resistência central à leptina (Volpato et al., 2012).

A maioria dos estudos relata os prejuízos da má nutrição materna somente na vida adulta dos filhotes. O meio ambiente em que a prole em desenvolvimento presencia durante o período perinatal é influenciado pela saúde materna e composição da sua dieta (Sullivan et al., 2014). No desmame, filhotes de mães com dieta rica em gordura durante a gestação e lactação, independente do sexo, já apresentaram maior adiposidade corporal e níveis plasmáticos elevados de triglicérides, leptina, glicose e insulina (Desai et al., 2014). Filhotes machos no mesmo período também mostram dificuldades em lidar com doses de glicose administradas durante o teste de tolerância à glicose (Chen et al., 2008; Tamashiro et al., 2009). Entretanto, pouco se sabe sobre os efeitos ambientais no início da vida da ninhada e os mecanismos pelos quais a dieta atua através do organismo materno para programar o metabolismo dos descendentes.

$\mathrm{Na}$ busca pelo entendimento desses mecanismos, tem sido empregadas técnicas moleculares com abordagens que incluem a caracterização de modificações epigenéticas, expressão de microRNAs, da microbiota intestinal, transcriptoma e expressão de mRNA de fetos e filhotes de mães obesas (Neri, Edlow, 2015). Durante o desenvolvimento, esses fetos são expostos a níveis elevados de ácidos graxos, glicose, leptina, insulina e fatores inflamatórios que podem alterar permanentemente sua regulação neuroendócrina, o metabolismo de substratos, a função mitocondrial e o destino celular (Heerwagen et al., 2010; Rivera et al., 2015). Assim, um dos desafios mais importantes nessa área que combina fisiologia fetal, metabolismo energético e biologia molecular é descobrir novos 
caminhos pelos quais o metabolismo materno altera a estrutura da cromatina por meio de eventos epigenéticos (Heerwagen et al., 2010).

Além de alterações metabólicas, recentemente tem sido descrita a associação entre a alimentação materna e o desenvolvimento de desordens neurocomportamentais como autismo, depressão, ansiedade e transtorno do déficit de atenção e hiperatividade nos descendentes (Ashwood et al., 2008; Ray et al., 2009; Sullivan et al., 2010). A ansiedade e depressão influenciam o comportamento e preferência alimentar do indivíduo, estando ligadas ao desejo por comidas palatáveis (Kelley et al., 2005). Ratos machos de mães expostas à dieta com alto teor de gordura saturada apresentam aumento da ansiedade e dificuldade na aprendizagem espacial (Bilbo, Tsang, 2010). Essas alterações tem sido relacionadas à prejuízos nos sistemas de serotonina, dopamina, melanocortina e à inflamação subclínica que a ingestão de dietas ricas em gordura promove no indivíduo (Das 2001; Grayson et al., 2010; Pitsavos et al., 2006; Sullivan et al., 2010; Vucetic et al., 2010). Recentemente, foi demonstrado que o consumo de dieta com alto teor de lipídeos induz a ansiedade e anedonia, promovendo uma perturbação na cascata intracelular de sinalização da insulina e da plasticidade sináptica (Dutheil et al., 2016).

Juntamente com a obesidade, tem crescido o número de problemas relacionados à fertilidade em homens e mulheres. Isso está relacionado aos distúrbios decorridos do acúmulo de gordura na ampla gama de hormônios que regulam as funções do sistema reprodutor (Cabler et al., 2010; Pasquali et al., 2003). Estudos indicam que quanto maior o índice de massa corporal, menor a qualidade do sêmen, a concentração de espermatozoides e maior a incidência de disfunção erétil (Corona et al., 2006; Jensen et al., 2004; Magnusdottir et al., 2005). Ratos com obesidade induzida por dieta tem espermatozoides com menor motilidade, o que reduz a qualidade do esperma (Fernandez et al., 2011).

Indivíduos obesos apresentam altos níveis de leptina sérica, o que reduz a quantidade de testosterona biodisponível (Michalakis et al., 2013). Os elevados e constantes níveis de leptina levam ao desenvolvimento da resistência central à sinalização da mesma, o que pode causar infertilidade por meio da reduzida ação dos neurônios que produzem o hormônio liberador de gonadotrofinas $(\mathrm{G} n \mathrm{RH})$, gerando um desequilíbrio no eixo hipotálamo-hipófise-gônada (Michalakis et al., 2013; Sheffer-Babila et al., 2013). Deste modo, a desregulação hormonal promovida 
pela dieta pode levar a alterações também no desempenho sexual. Ratas que tiveram alimentação com dieta do tipo cafeteria durante a prenhez e lactação têm um baixo percentual de filhotes que realizam intromissões nas fêmeas quando adultos. Dentre os animais que exibem esse comportamento, a frequência é menor do que nos ratos de mães com dieta controle (Jacobs et al., 2014). São escassos na literatura os dados que relacionam o consumo de dieta hiperlipídica pela mãe e o comportamento sexual dos descendentes.

\subsection{Comportamento materno}

O comportamento materno, essencial para a sobrevivência do neonatos em algumas espécies, refere-se a comportamentos apresentados durante os dias próximos e após o parto, uma vez que os neonatos possuem limitada capacidade motora e termorreguladora e são completamente dependentes da mãe para obtenção de nutrientes, proteção e manutenção da temperatura corporal. Tais comportamentos estão relacionados aos cuidados diretos com a prole, como lamber, amamentar e carregar os filhotes, e indiretos como o aumento de agressividade materna para a proteção da cria. Em pequenos roedores, a dependência da mãe é tão grande que nos primeiros dias após ao parto os filhotes precisam dela para estímulos de micção e defecação (Numan, Insel, 2003).

Ao se tornarem mães, as fêmeas também apresentam redução do medo $e$ capacidade de memória e aprendizado aumentada, o que auxilia em momentos que ela necessita deixar o ninho para buscar alimento (Kinsley, 2008; Kinsley et al., 1999; Zimberknopf et al., 2011). A motivação da mãe em cuidar de sua prole é medida principalmente pelos parâmetros apetitivos do comportamento materno, ou seja, a busca pelo filhote e a construção de ninho, que podem ser iniciados na ausência de contato físico da mãe com os filhotes (Terkel et al., 1979).

As interações mãe-filhote são capazes de transmitir ao neonato sinais sobre a qualidade do ambiente em que estão inseridos, impactando o crescimento, sobrevivência, fisiologia e comportamento do descendente (Curley, Champagne, 2016). Deste modo, a capacidade do filhote de alterar o seu desenvolvimento em resposta à qualidade dos cuidados maternos pode representar uma importante via adaptativa às condições da vida (Cameron et al., 2005). Portanto, fatores que promovam alterações no comportamento materno durante o período pós-natal têm 
impacto direto sobre os descendentes. Filhotes de ratas que exibem cuidados maternos reduzidos entram na puberdade mais cedo e mostram comportamento sexual alterado (Cameron et al., 2008). Mães que realizam menos grooming dos filhotes e dedicam menos atenção aos mesmos possuem descendentes com aumentos dos comportamentos semelhantes à ansiedade, e mães com comportamento oposto têm filhotes menos ansiosos e mais hábeis para lidar com situações de estresse (Walker, 2010; Weaver et al., 2006).

A nutrição materna é um agente externo capaz de influenciar mudanças na expressão gênica dos filhotes por meio de mecanismos epigenéticos (Lillycrop et al., 2005). No entanto, a ligação entre nutrição e cuidados maternos começou a ser entendida mas não está completamente estabelecida (Curley, Champagne, 2016).

Mulheres obesas ao se tornarem mães têm maior propensão a ter atraso na lactogênese e apresentar lactação insuficiente (Lepe et al., 2011). Do mesmo modo, Hernandez et al., (2012) afirmam que a alimentação rica em lipídeos pode causar prejuízos na lactação de animais de laboratório. Connor et al., (2012) ao avaliar parâmetros do comportamento materno de ratas alimentadas com dieta hiperlipídica desde o primeiro dia de prenhez, viram que essas mães lambem e realizam menos o grooming nos filhotes. Buonfiglio et al., (2016) observaram que camundongos fêmeas alimentadas com dieta rica em gordura antes e durante a gestação e lactação apresentam redução na produção do leite, alterações no desenvolvimento da glândula mamária e maiores latências para a busca dos filhotes. Entretanto, uma análise mais detalhada do comportamento materno precisa ser realizada neste contexto, pois além dos dados da literatura serem escassos, os cuidados maternos deficientes e uma pobre relação mãe-filhote geram impactos sobre o desenvolvimento dos neonatos e podendo aumentar o risco de doenças (Connor et al., 2012).

Dentre os aspectos do comportamento materno, a produção e ejeção do leite são componentes importantes. Tais processos resultam de um complexa interação entre os hormônios esteroides e peptídeos expressos durante a gestação e a glândula mamária, estimulando o desenvolvimento das mamas e o início da secreção de leite (Neville et al., 2002).

Ratas obesas mostram prejuízo no desenvolvimento da glândula mamária e da lactogênese (Flint et al., 2005). Em ratos, prover leite para a ninhada está associado com um aumento significativo da ingestão calórica, uma redução no gasto 
energético e mudanças no padrão de utilização e armazenamento de energia (Woodside et al., 2012). O consumo de alimentos ricos em lipídeos altera a fonte de obtenção energética e consequentemente causa alterações na composição do leite (Bautista et al, 2016). O tecido adiposo participa do desenvolvimento da glândula mamária, mas não é necessário para sua diferenciação (Couldrey et al., 2002). Entretanto, o acúmulo exacerbado desse tecido como ocorre na obesidade é prejudicial ao estabelecimento da lactação (Flint et al., 2005).

Após o parto, a manutenção do desenvolvimento da glândula mamária, a contínua produção de leite e o controle da ejeção do mesmo são hormôniodependentes: prolactina age sobre a produção do leite e a oxitocina tem função na ejeção do mesmo. Entretanto, a síntese e liberação desses hormônios são dependentes de estímulos sensoriais provindos em grande parte da sucção dos filhotes (Jonas, Woodside, 2016; Numan, Insel, 2003). Deste modo, qualquer interferência promovida no controle desses mecanismos pode interferir na qualidade da interação mãe-filhote, trazendo prejuízos para ambos.

\subsection{Opióides}

Opióides são substâncias de origem endógena ou sintética, que referem amplamente a todos os compostos que estão relacionados ao ópio. O ópio, extraído da semente da papoula (Papaver somniferum), tem seu termo derivado da palavra grega opos que significa suco, referindo-se ao suco produzido da papoula. Possui potentes propriedades de alívio da dor e indução de euforia (Le Merrer et al., 2009).

Os receptores opióides $\mu, \mathrm{k}$ e $\delta$ são amplamente distribuídos na periferia e no sistema nervoso central, regulando numerosas funções fisiológicas como analgesia e nocicepção, respiração, trânsito gastrointestinal, respostas ao estresse, além de funções endócrinas e imunes (Bodnar, 2016; Le Merrer et al., 2009). Além dessas funções, o sistema opióide está ligado à inibição da expressão do comportamento materno (Bridges, Grimm, 1982; Grimm, Bridges, 1983), e tem papel importante na ingestão e preferência alimentar (Gosnell, Levine, 2009; Li et al., 2006; Nailed et al., 2007).

Estudos têm relatado que alimentos com alto teor de gordura ou de açúcar podem desencadear mudanças cerebrais duradouras em humanos e roedores, tornando difícil resistir à ingestão exagerada desses alimentos, sendo tais indivíduos 
mais propensos à obesidade e suas consequentes alterações metabólicas (Morris et al., 2015). Sabe-se que o consumo e gasto de energia são regulados por uma complexa rede de sistemas neuroquímicos, tendo os sistemas de recompensa função importante nesse controle e interferindo na palatabilidade do alimento. Neste sentido, um estudo comparou imagens cerebrais de mulheres magras e obesas por tomografia por emissão de pósitrons. Foi constatado que a associação entre receptores opióides e receptores de dopamina existente na área tegmentar ventral (VTA), componente do sistema recompensa, em mulheres magras é perdida em mulheres com obesidade mórbida, sugerindo que essas mulheres com peso corporal elevado tem o sistema recompensa com função comprometida (Tuominen et al., 2015).

Quando é permitido aos animais fazerem a seleção de que tipo de macronutriente optariam em sua dieta, injeções de morfina, um agonista opióide preferencialmente $\mu$, causam um aumento da preferência por ingestão de gordura e diminuição na ingestão de carboidratos. Já a naloxona, um antagonista dos receptores opióides, diminui a ingestão de gordura (Gosnell, Levine, 2009; MarksKaufman, 1982). Porém, esse papel na preferência por lipídeos não é totalmente compreendido (Taha, 2010). Os opióides também parecem estar ligados ao controle do balanço energético mediado pelos hormônios leptina e insulina em resposta à ingestão alimentar, agindo em neurônios anorexigênicos no hipotálamo (Maolood, Meister, 2008). Insulina administrada na VTA, atuante no sistema recompensa, inibe a alimentação induzida por opióides, assim como a ingestão de alimentos palatáveis após a saciedade (Mebel et al., 2012; Sipols et al., 2002). Esses dados indicam a complexidade do sistema e a estreita relação entre os opióides e o metabolismo. Deste modo, a ingestão de dieta rica em gordura pode ser capaz de causar alterações na expressão dos receptores opioidérgicos, alterando a relação do indivíduo com o alimento.

Animais em que a mãe foi exposta à alta ingestão de lipídeos durante a gestação e lactação apresentam quando adultos hipometilação do gene do receptor $\mu$-opióide, maior expressão desse receptor no núcleo accumbens e no hipotálamo, e preferência por gordura aumentada quando comparado ao controle (Vucetic et al., 2010). Isso indica que a alimentação materna, por meio de mecanismos epigenéticos, pode programar o desenvolvimento do sistema opióide do descendente, em áreas ligadas ao sistema recompensa (Grissom et al., 2014; 
Vucetic et al., 2010). Assim, a investigação sobre o papel dos receptores opióides hipotalâmicos na ingestão alimentar e no comportamento materno em mães roedoras submetidas à dieta hiperlipídica torna-se relevante.

\subsection{Fatores de transcrição neurais e a dieta hiperlipídica}

Em modelos de roedores que exploram a influência da alimentação materna sobre os descendentes, as fêmeas são alimentadas com dieta rica em lipídeos durante a gestação e lactação. Em sua maioria, os filhotes são mantidos até atingirem a vida adulta e então têm seu fenótipo metabólico comparado com o de filhotes de mães mantidas a dieta padrão durante o mesmo período. Os resultados destes estudos indicam que os filhotes de mães que ingeriram alto teor de lipídeos comem significativamente mais, apresentam maiores quantidades de gordura corporal, altos níveis de triglicérides, glicemia plasmática alterada e sensibilidade à insulina reduzida, como apresentado anteriormente (Ainge et al., 2011). Ademais, esses descendentes possuem maiores concentrações de leptina e insulina, além de um acúmulo anormal de lipídeos nos adipócitos apesar de consumirem a mesma dieta que os animais controle após o desmame. Isto mais uma vez sugere que a exposição à dieta hiperlipídica programa o metabolismo desses animais, tornandoos mais propensos a se tornarem obesos (Howie et al., 2009; Sloboda et al., 2009; Volpato et al., 2012).

Hormônios como os esteroides adrenais, os esteroides sexuais e os tireoidianos exercem amplas ações no desenvolvimento cerebral (Bouret et al., 2004; MacKay, Abizaid, 2014). O feto e o neonato estão portanto expostos à riscos durante o tempo em que dependem da mãe, sendo este um período que engloba as principais fases da organogênese, da diferenciação sexual e do desenvolvimento neural (Mackay et al., 2013). Assim, um desequilíbrio do estado metabólico e hormonal devido a má nutrição materna durante a gestação e lactação pode interferir com o desenvolvimento cerebral (Ross, Dessai, 2014). Isso é particularmente importante uma vez que tem sido demonstrado que a leptina, a insulina e a grelina, hormônios majoritariamente relacionados ao controle energético, têm sido relacionados a diversos aspectos do desenvolvimento hipotalâmico (Bouret, 2013). 
Uma forma sob a qual a sobrecarga calórica pode programar o metabolismo do filhote seria alterando o desenvolvimento dos circuitos hipotalâmicos que regulam o peso corporal e o balanço energético (Bouret, 2009; Sullivan et al., 2014). Sendo esses circuitos sensíveis a uma série de hormônios e nutrientes, uma alteração destes fatores pode alterar a atividade e a estrutura do hipotálamo durante períodos cruciais do desenvolvimento (Vogt et al., 2014). Em camundongos, a neurogênese hipotalâmica ocorre entre os dias embrionários 10 e 16, sendo um pouco mais tardia no rato (Michaud et al., 1998). Embora as vias moleculares que medeiam o desenvolvimento do hipotálamo são ainda bastante desconhecidas, alguns fatores importantes nesse período já foram identificados (Shimogori et al., 2010).

Neurônios localizados no núcleo arqueado do hipotálamo (Arc) e que produzem peptídeos orexigênicos, como o neuropeptídeo $\mathrm{Y}$ (NPY) e o peptídeo relacionado a proteína Agouti (AgRP), ou peptídeos anorexigênicos como a proopiomelanocortina (POMC) e o transcrito relacionado à anfetamina e cocaína (CART) são os principais componentes das vias de regulação da ingestão alimentar e do balanço energético (Morton et al., 2014; Schwartz et al., 2000). Destes, a expressão de POMC parece ser a mais sensível à exposição de altas concentrações de gordura e de tóxicos ambientais como o bisfenol $A$, o que levam ao aumento da vulnerabilidade a obesidade (Clark et al., 1984; Fan et al., 1997; Horvath et al., 2010; MacKay et al., 2013; Rossi et al., 1998). Deste modo, um mecanismo potencial pelo qual a dieta hiperlipídica materna poderia causar alterações que favoreçam o aparecimento de variações metabólicas incluiria um desequilíbrio nos fatores que controlam o destino ou a expressão desses peptídeos.

Um desses fatores é a Neurogenina 3 (Ngn3), um fator de transcrição expresso em fases iniciais do desenvolvimento do hipotálamo que está associado a expressão de POMC (Ma et al., 1996; Pelling et al., 2011; Sommer et al., 1996). De modo interessante, o Ngn3 promove o desenvolvimento dos neurônios POMC enquanto que impede o desenvolvimento dos neurônios NPY, especialmente nos dias 10 a 14 de gestação (Pelling et al., 2011). Perifericamente, esse fator é expresso nas células $\beta$ das ilhotas pancreáticas e nas células endócrinas do intestino, atuando também na homeostase energética (Gradwohl et al., 2000; Schonhoff et al., 2004). Além disso, recentemente foi desenvolvido um modelo animal de obesidade com base na inativação hipotalâmica do Ngn3 em embriões de camundongo. Essa deleção condicional do gene resultou em animais que tornam-se 
obesos rapidamente após o desmame, estando associados à hiperfagia e redução do gasto energético. Esse animais perdem a expressão de POMC nos neurônios hipotalâmicos, o que indica uma especificação incompleta dos neurônios anorexigênicos (Anthwal et al., 2013). Assim, o Ngn3 é um potencial mecanismo de ação da dieta hiperlipídica materna, o qual se alterado poderia causar alterações na programação hipotalâmica dos descentes.

Outro possível fator é o Mammalian achaete scute homolog-1 (Mash1) que é um gene pró-neural, no qual a diminuição da expressão resulta em hipoplasia do Arc e do núcleo ventromedial do hipotálamo (VMH). O Mash1 não é determinante para a expressão do POMC, mas é imprescindível para o desenvolvimento normal desses neurônios (McNay et al., 2006). Além disso, animais knockout para Mash1 apresentam reduções substanciais no número de neurônios que expressam NPY e POMC (McNay et al., 2006). Portanto, alterações na expressão de Ngn3 e Mash1 podem alterar significativamente o desenvolvimento dos neurônios reguladores do apetite (Pelling et al., 2011). Foi demonstrado a redução de ambos os fatores em animais obesos adultos, nos quais somente as mães foram alimentadas com ração hiperlipídica (Desai et al., 2016). Porém, não foi determinado se essa diminuição é resultado da programação no ambiente fetal ou uma consequência da obesidade desenvolvida pelos animais.

Retina and anterior neural fold homeobox (Rax) é um fator de transcrição expresso no Arc e no VMH. Sua eliminação nesses núcleos levam a perda severa dos fenótipos celulares nesses locais, demonstrando um papel na especificação do destino neuronal (Lu et al., 2013). O Rax também participa na definição do domínio rostro-caudal no hipotálamo de embriões de roedores (Ferran et al., 2015).

O SIX homeobox 3 (Six3) promove as indicações necessárias para a formação do prosencéfalo, que inclui o hipotálamo, e do desenvolvimento ocular. Ele é um fator de transcrição que se liga a sequências específicas de DNA e controla se o gene será ativado ou inativado, sendo crucial para o desenvolvimento embrionário (Lagutin et al., 2013; Oliver et al., 1995). Deste modo, o Rax e o Six3 também são mecanismos potenciais pelos quais a dieta hiperlipídica materna pode alterar a programação da ingestão alimentar e do balanço energético durante o desenvolvimento.

Além disso, ainda não se sabe se a nutrição com alta carga lipídica pode interferir na expressão de neuropeptídeos que estão envolvidos com a alimentação e 
controles metabólicos, como o POMC, NPY e AgRP, desde a fase de proliferação neuronal em momentos inicias da vida do descendente. 
"A menos que modifiquemos a nossa maneira de pensar, não seremos capazes de resolver os problemas causados pela forma como nos acostumamos a ver o mundo."

Albert Einstein

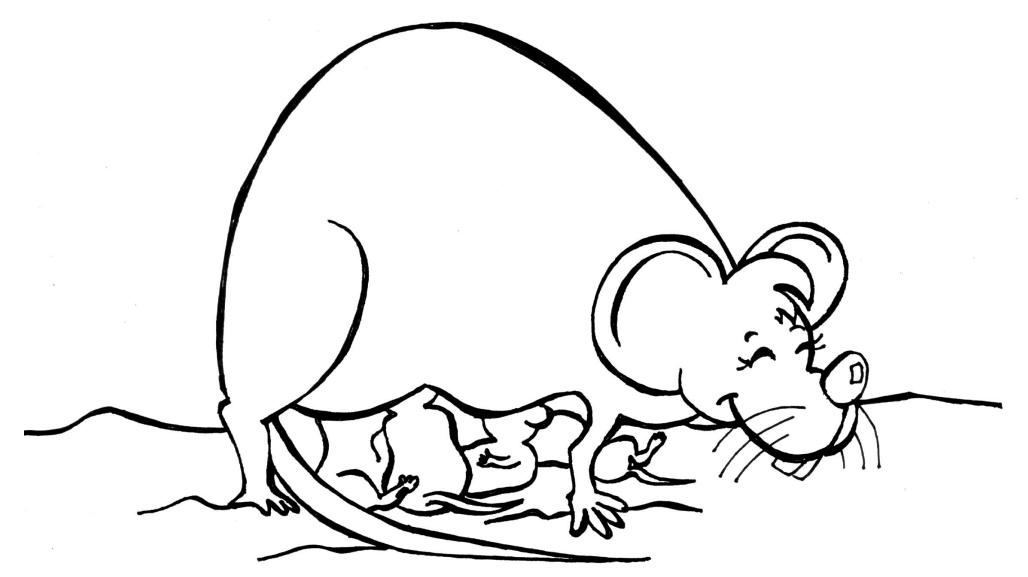

2 OBJETIVOS 
O objetivo principal deste estudo foi avaliar a influência da dieta hiperlipídica durante a prenhez e lactação de ratas sobre o comportamento materno, desenvolvimento dos filhotes, as conseqüências na vida adulta dos mesmos, e sobre o sistema opióide endógeno central nesse contexto.

Objetivos específicos:

- Avaliar a exibição do comportamento materno em duas gerações de ratas alimentadas com dieta padrão e dieta hiperlipídica.

- Observar padrões na ingestão alimentar de ratas alimentadas com os diferentes tipos de dieta durante a prenhez e lactação $\left(F_{0}\right.$ e $\left.F_{1}\right)$;

- Caracterizar as alterações metabólicas decorrentes de ingestão de dieta rica em lipídeos por meio de alterações dos níveis glicêmico, no teste de tolerância a glicose e teste de tolerância a insulina das mães $\left(F_{0}\right.$ e $\left.F_{1}\right)$ assim como o peso do fígado e do tecido adiposo retroperitoneal e retrogonadal, órgãos que sofrem influência direta do consumo de lipídeos;

- Analisar os parâmetros de desenvolvimento físico e sexual de filhotes de mães nutridas ou não com dieta hiperlipídica;

- Avaliar os padrões de expressão dos receptores opióides $\mu, \mathrm{k}$ e $\delta$ em mães $\left(F_{0}\right.$ e $\left.F_{1}\right)$ alimentadas com dieta padrão ou dieta hiperlipídica durante a gestação e lactação;

- Investigar os comportamentos de ansiedade e sexual em machos adultos alimentados com dieta rica em lipídeos, e avaliar a influência da alimentação materna sobre esses comportamentos;

- Avaliar a influência da alimentação materna rica em gordura sobre a expressão gênica de fatores de transcrição neuronais que atuam no desenvolvimento do hipotálamo dos descendentes, bem como de peptídeos que regulam a ingestão alimentar. 
"É mais fácil obter o que se deseja com um sorriso do que à ponta da espada." William Shakespeare

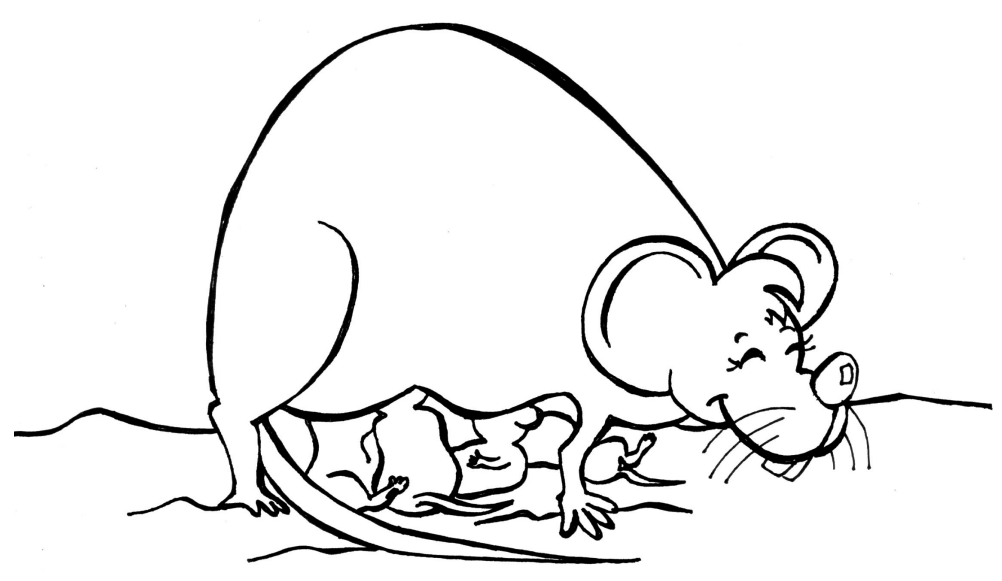


A Figura 1 apresenta um esquema que ilustra as principais análises realizadas com as mães (geração $F_{0}$ ) e os filhotes (geração $F_{1}$ ) de acordo com a ordem cronológica, durante a gestação, lactação e período pós-desmame dos animais.

Figura 1 - Esquema representativo das análises feitas com as mães e os filhotes. Análises da mãe $\left(F_{0}\right)$

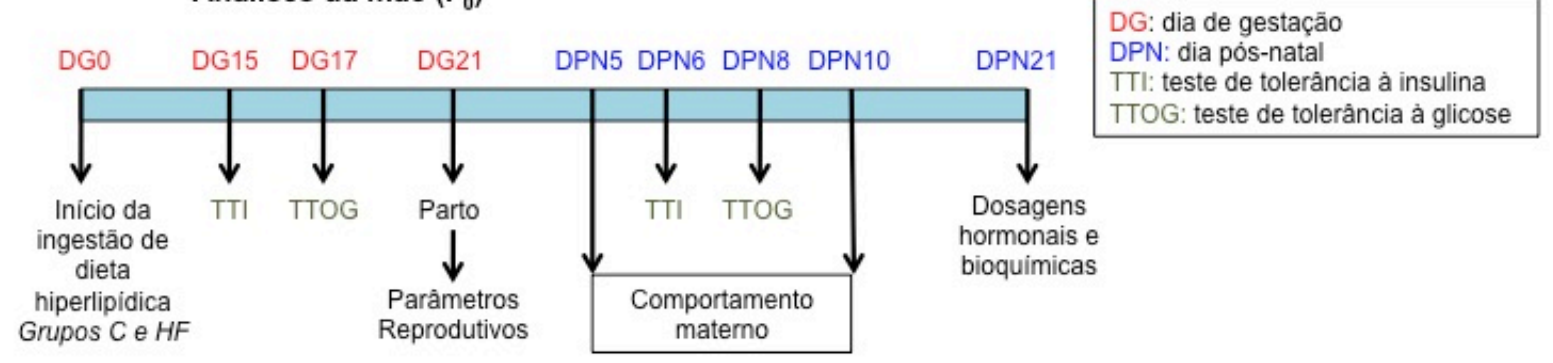

Análises dos filhotes $\left(F_{1}\right)$

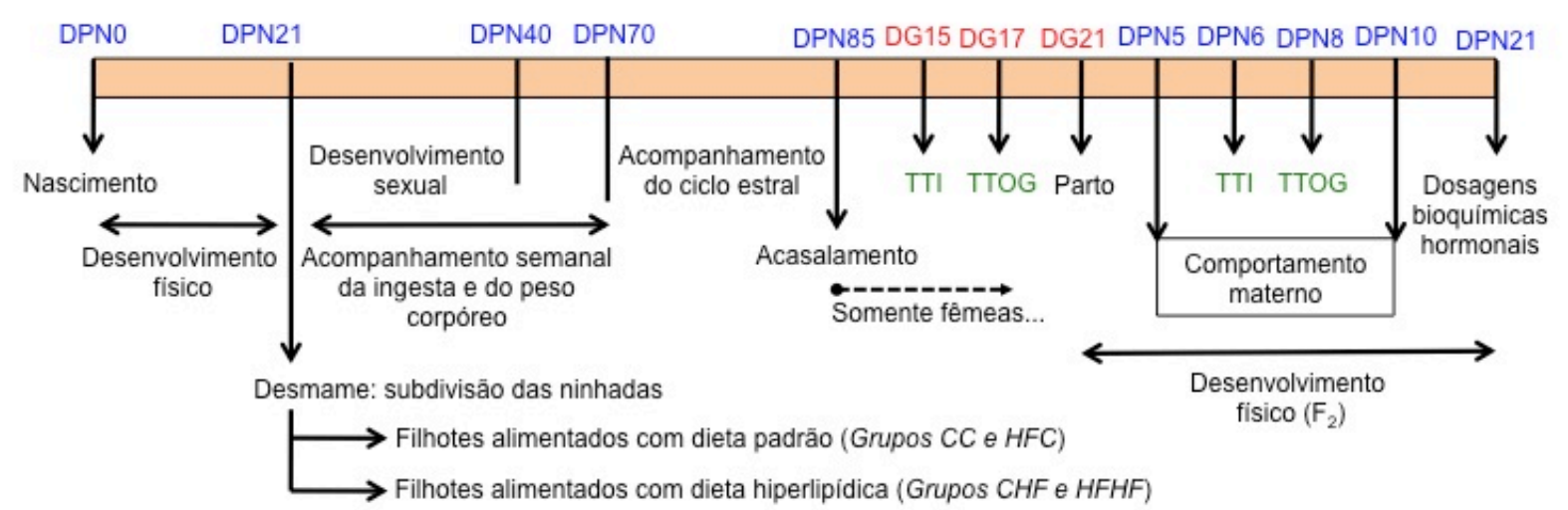

Após o desmame dos filhotes, cada ninhada foi dividida em dois subgrupos: um que continuou a receber a mesma dieta que a mãe, e outro que recebeu dieta diferente da que a mãe foi submetida durante a gestação e lactação, resultando assim em 4 grupos experimentais (CC, CHF, HFC, HFHF). No dia de realização das dosagens bioquímicas e hormonais, também foi realizado a análise da expressão dos receptores opióides. C: controle; HF: dieta hiperlipídica (high fat).

Para fins de simplificação, a figura 1 descreve somente as análises realizadas nas fêmeas da geração $F_{1}$ a partir do DPN (dia pós-natal) 70. Entretanto, após esse dia os machos dos quatro grupos experimentais foram submetidos a testes comportamentais para avaliar os níveis de ansiedade e do desempenho sexual desses animais (ver 3.8).

A completa descrição de todos os procedimentos realizados encontra-se nos itens a seguir. 


\subsection{Animais}

Foram utilizados 20 machos e 40 fêmeas (Rattus norvegicus) da linhagem Wistar virgens, com aproximadamente 80 dias de idade, provenientes do Departamento de Patologia da Faculdade de Medicina Veterinária e Zootecnia da Universidade de São Paulo. Os animais foram alojados em gaiolas de polipropileno medindo $30 \times 40 \times 18 \mathrm{~cm}$, em salas com sistema de ventilação $\left(23 \pm 2{ }^{\circ} \mathrm{C}\right)$ e ciclo de luz de 12 horas claro/ 12 horas escuro (08:00 horas - 20:00 horas). Água e ração foram fornecidas ad libitum durante todos os experimentos. Este estudo está de acordo com os padrões internacionais de experimentação animal (Committe on Care and Use of Laboratory Animal Resources - National Research Council/USA) e das Comissões de Ética no Uso de Animais do Instituto de Ciências Biomédicas ( $n^{\circ} 135$, fls 135, livro 2) e da Faculdade de Medicina Veterinária e Zootecnia ( $\left.n^{\circ} 2848 / 2012\right)$ da Universidade de São Paulo.

Uma parte dos experimentos foi realizada na Carleton University (Ottawa, Canadá), sendo utilizado 5 machos e 32 fêmeas da linhagem Wistar. Todos os procedimentos foram aprovados pelo Comitê de Cuidados Animais da Carleton University (Carleton University Animal Care Committee) e seguiram os padrões determinados pelo Conselho Canadense de Cuidados Animais (Canadian Council on Animal Care). Os procedimentos adotados para este experimento estão descritos em uma subseção própria - ver 3.9.

\subsection{Procedimentos Experimentais}

Ao término do período claro do ciclo, as ratas foram colocadas na gaiola de um rato macho sexualmente experiente para o acasalamento, seguindo a proporção de duas fêmeas para cada macho. No início do período claro do dia seguinte, foi realizada a análise de citologia vaginal para confirmar a presença de espermatozóides, considerando este o dia zero (0) de gestação (DG0). As ratas foram mantidas individualmente durante a gestação e lactação.

Confirmada a prenhez, as ratas foram divididas aleatoriamente em dois grupos: controle $(C)(n=9)$, no qual os animais receberam dieta de ração padrão (Nuvilab CR $1^{\circledR}$ - Quimtia Feed, Colombo, PR, Brasil) do dia 0 de prenhez até o dia 21 de lactação (dia pós-natal, DPN21); grupo HF $(n=10)$, em que os animais 
receberam dieta de ração hiperlipídica (45\% kcal de gordura - Pragsoluções Biociências $^{\circledR}$, Jaú, SP, Brasil) durante o mesmo período (Connor et al., 2012; Howie et al., 2009). Maiores detalhes das rações utilizadas podem ser obtidos a seguir; ver 3.2.1.

No dia seguinte ao parto (DPN1), as ninhadas foram padronizadas para 8 filhotes (4 machos e 4 fêmeas).

\subsubsection{Composição das rações}

A ração padrão utilizada possui $2980 \mathrm{kcal} / \mathrm{Kg}$ de energia metabolizável sendo constituída por 22 a 22,5\% de proteína bruta, 4 a $5 \%$ de extrato etéreo (gordura) e 53 a 55\% de carboidratos em quantidade. Sua composição básica contém milho integral moído, farelo de soja, farelo de trigo, carbonato de cálcio, fosfato bicálcico, cloreto de sódio, vitamina $A$, vitamina $D 3$, vitamina $E$, vitamina $K 3$, vitamina $B 1$, vitamina $\mathrm{B} 2$, vitamina $\mathrm{B} 6$, vitamina $\mathrm{B} 12$, niacina, pantotenato de cálcio, ácido fólico, biotina, cloreto de colina, sulfato de ferro, monóxido de manganês, óxido de zinco, sulfato de cobre, iodato de cálcio, selenito de sódio, sulfato de cobalto, lisina, metionina e BHT como aditivo, de acordo com informações do fabricante.

A ração hiperlipídica $45 \%$ utilizada neste estudo possui composição básica semelhante à ração padrão, sendo $4590 \mathrm{kcal} / \mathrm{Kg}$ de energia metabolizável. Em quantidade, possui $8 \%$ de matéria mineral, $22 \%$ de proteína bruta, $23 \%$ de extrato etéreo (gordura - o que equivale a $45,1 \%$ em quilocalorias), $6 \%$ de fibra bruta e $41 \%$ de carboidratos. As fontes de gordura são 16,8\% (p/p) de banha (ácidos graxos saturados) e o restante, em sua maioria, óleo de soja e uma fração mínima de óleo de milho (ácidos graxos insaturados).

\subsection{Análises das mães - Geração $F_{0}$}

As fêmeas prenhes foram pesadas diariamente durante toda a gestação e lactação para acompanhamento do peso corpóreo e a ingestão alimentar foi monitorada a cada 3 dias durante a gestação, e diariamente durante a lactação. Também foi determinada a duração da prenhez, o tamanho da ninhada e a razão de machos e fêmeas em cada ninhada. 
As ratas foram submetidas aos testes de tolerância à insulina e de tolerância oral à glicose na prenhez e lactação. Na gestação, o teste de tolerância a insulina (TTI) foi realizado no DG15, e o teste de tolerância oral a glicose (TTOG) no DG17. Durante a lactação, para não comprometer as observações do comportamento materno nos DPN 5 e 10, o teste de tolerância à insulina (TTI) foi realizado no dia seguinte, no DPN 6. Para garantir que não houve interferência do TTI no teste de tolerância à glicose, o TTOG foi realizado 2 dias após o TTI, no DPN 8. Todos os grupos experimentais foram submetidos aos mesmos procedimentos.

\subsubsection{Determinação dos níveis glicêmicos durante a gestação}

Amostras de sangue da veia caudal foram coletadas nos dias DG 0, 7, 14 e 21 para determinação dos níveis de glicemia dos animais, através de um glicosímetro (One Touch Ultra, Johnson \& Johnson do Brasil Indústria e Comércio de Produtos para Saúde Ltda $^{\odot}$, São Paulo, SP, Brasil), sendo os valores expressos $\mathrm{mg} / \mathrm{dL}$.

\subsubsection{Teste de tolerância à insulina}

O TTI foi realizado nos dias DG15 e DPN6. Após restrição alimentar de 6 horas, ratas dos grupos $\mathrm{C}(\mathrm{n}=9)$ e HF $(n=10)$ receberam uma injeção subcutânea de solução de insulina (3.33 $\mathrm{U} / \mathrm{mL})$ na região dorsal do pescoço $(30 \mu \mathrm{l} / 100 \mathrm{~g}$ peso corpóreo) (Mello et al., 2001; Tietz, 1986). Amostras de sangue foram obtidas da cauda para determinação da glicemia (Glicosímetro One Touch Ultra) 0, 15, 30, 60, 90 e 120 minutos após a injeção de insulina.

\subsubsection{Teste de tolerância oral à glicose}

O TTOG foi realizado nos DG17 e DPN8. Após restrição alimentar de 6 horas, ratas dos grupos $C(n=9)$ e HF $(n=10)$ receberam solução de glicose $(200 \mathrm{~g} / \mathrm{L})$ por via intragástrica (gavagem - $2 \mathrm{~g} / \mathrm{kg}$ peso corporal). Amostras de sangue foram obtidas da cauda para determinação da glicemia (Glicosímetro One Touch Ultra) 0 , 15, 30, 60, 90 e 120 minutos após a gavagem (De Mello et al., 2001; Tietz, 1986). As 
mudanças na glicemia durante o teste de tolerância à glicose foram avaliadas pelo cálculo da área total sob a curva (AUC) usando o método trapezóide (Tai, 1994).

\subsubsection{Análises do comportamento materno}

A fim de investigar a influência de uma dieta rica em lipídeos durante a prenhez e lactação sobre o comportamento materno, foram realizados dois tipos de análise do comportamento materno, como descrito a seguir.

As análises foram conduzidas nos DPN 5 ou 6 e 10 ou 11. Esses dias foram escolhidos porque no DPN 5 a lactação tem um custo energético mais baixo e capacidade de locomoção dos filhotes é menor, sendo também este o dia de maior intensidade de expressão do comportamento materno (Numan et al., 2006; Woodside et al., 2012), já no DPN 10 a lactação tem um custo energético muito maior e a capacidade de locomoção dos filhotes também é maior.

\subsubsection{Análise do comportamento materno após a mãe ter sido privada dos filhotes}

O comportamento materno nesse modelo foi filmado nos DPN 6 e 11 para ambos os grupos. No dia do teste, todos os filhotes foram removidos da caixa moradia e os ninhos destruídos. Decorridos 30 minutos, os filhotes foram recolocados na caixa moradia e a interação mãe-filhote foi gravada por 30 minutos. Este tipo de análise permite fazer uma verificação da motivação que a mãe possui para buscar e cuidar de seus filhotes.

Foram avaliados os seguintes parâmetros: latência para busca do $1^{\circ}, 5^{\circ}$ e $8^{\circ}$ filhote, devolução dos filhotes ao ninho (número de buscas pelos filhotes), tempo gasto agrupando os filhotes, tempo gasto realizando auto-limpeza das mamas, tempo gasto lambendo os filhotes, tempo total amamentando em posição de cifose (crouching), tempo gasto sem interação com os filhotes (fora do ninho), tempo total gasto na construção de ninho, tempo gasto amamentando 4 ou menos filhotes sem posição de cifose, tempo gasto amamentando 5 ou mais filhotes sem posição de cifose. A presença de comportamento materno total (CMT) foi analisada e este parâmetro foi considerado quando a fêmea agrupou pelo menos 5 filhotes no ninho e os amamentou em posição de cifose por no mínimo 3 minutos consecutivos. Considera-se CMT com a mãe sobre no mínimo 5 filhotes, porque é importante que 
haja essa quantidade de filhotes para que a posição de cifose seja assumida com maior velocidade e em maior grau (Stern, Johnson, 1990). Todas as análises deste comportamento foram realizadas através do programa Etholog 2.0 (Ottoni, 2000).

\subsubsection{Análise do comportamento materno sem intervenção prévia}

Este tipo de avaliação permite um melhor estudo sobre a amamentação e as ejeções de leite produzidas pela rata. As interações mãe-filhote sem intervenção prévia foram gravadas na caixa moradia por 6 horas consecutivas na fase clara do ciclo. Ou seja, nenhum tipo de manipulação foi realizado na lactante e em seus filhotes em no mínimo 3 horas antes do início do teste.

$\mathrm{Na}$ análise dos vídeos, os comportamentos foram avaliados a cada minuto de acordo com as seguintes categorias: agrupamento de filhotes, comportamento de limpeza dos filhotes, comportamento de auto-limpeza, construção de ninho, número de visitas ao ninho, amamentação sem posição de cifose, amamentação em posição de cifose (crouching) e tempo total sem qualquer tipo de interação com os filhotes, independente da posição da rata na caixa. A mamada de maior duração foi identificada e utilizada para análise da latência para primeira ejeção de leite, número total de ejeções durante o período, assim como o intervalo médio entre cada ejeção.

\subsubsection{Análise materna no desmame}

Após o desmame, no DPN21, as mães passaram por uma restrição alimentar durante 6 horas e os níveis glicêmicos desses animais após esse período foram determinado com auxílio de glicosímetro. Em seguida, as fêmeas sofreram eutanásia por decapitação e tiveram seu sangue coletado para realização de análises bioquímicas e hormonais posteriores. O sangue, após ser coletado, foi imediatamente centrifugado (2000 rpm por 20 minutos a $4{ }^{\circ} \mathrm{C}$ ) e o soro mantido a -20 ${ }^{\circ} \mathrm{C}$ até o momento das dosagens (ver 3.3.6).

A seguir, as fêmeas tiveram seu encéfalo rapidamente retirado, o hipotálamo foi dissecado e armazenado a $-80^{\circ} \mathrm{C}$, sendo uma parte dos hipotálamos destinados para posterior análise da expressão dos genes Oprm1, Oprk1 e Oprd1 dos receptores opióides $\mu, \mathrm{k}$ e $\delta$, e a outra parte para análise de expressão de suas proteínas MOR, KOR e DOR, respectivamente (ver 3.3.7). 
Além da coleta de sangue e do hipotálamo das fêmeas, o fígado e as gorduras retroperitoneal e retrogonadal foram retirados para avaliar possíveis efeitos da dieta sobre esses órgãos.

\subsubsection{Análises bioquímicas e hormonais}

A concentração de colesterol total, HDL-colesterol, LDL-colesterol, triglicérides, aspartato amino transferase (AST) e alanina amino transferase (ALT) no soro dos animais foi determinada utilizando kits de diagnóstico padrão de acordo com as instruções do fabricante (Labtest Diagnóstica S.A., Lagoa Santa, MG, Brasil) no equipamento ELx800 TM (BioTek Instruments Inc., Winooski, VT, Estados Unidos).

A determinação dos níveis séricos dos hormônios leptina e insulina foi realizada por ensaio imunoenzimático (ELISA), de acordo com as instruções do fabricante (Crystal Chem Inc., Downers Grove, IL, Estados Unidos).

\subsubsection{Expressão dos genes Oprm1, Oprk1 e Oprd1}

Imediatamente após a eutanásia por decapitação, o encéfalo dos animais foi retirado e lavado em água ultrafiltrada esterilizada por autoclave e mantido em gelo. Em seguida, a área de interesse, o hipotálamo, foi retirada com bisturi, mergulhada em $500 \mu \mathrm{l}$ de solução de TRIzol (Thermo Fisher Scientific Inc., Waltham, MA, Estados Unidos) e mantida em freezer $-80^{\circ} \mathrm{C}$, até o momento da extração do RNA, seguindo-se as especificações do fabricante. O hipotálamo foi dissecado com base nas coordenadas obtidas no Atlas de Paxinos e Watson (1998).

\subsubsection{Ensaio de Transcrição Reversa (RT-PCR)}

A expressão dos genes Oprm1, Oprk1 e Oprd1 foi investigada por meio de transcrição reversa, utilizando-se o SuperscriptTM II RNAse H- Reverse Transcriptase (Invitrogen ${ }^{\mathrm{TM}}$, Thermo Fisher Scientific Inc., Waltham, MA, Estados Unidos). As condições de reação foram estabelecidas de acordo com as indicações do fabricante.

Aos tubos de microcentrífuga contendo as amostras de RNA total tratadas com DNAse I, foram adicionados $1 \mu \mathrm{l}$ de oligo DT e $1 \mu \mathrm{l}$ de dNTPs (mistura de 10 
$\mathrm{mM}$ de cada dNTP). Essa reação foi encubada por 5 minutos à $65^{\circ} \mathrm{C}$ e depois transferida para gelo. Então foram acrescentados às amostras Superscript buffer $1 \mathrm{x}$ (Superscript II - Invitrogen ${ }^{\mathrm{TM}}$ ), $2 \mu \mathrm{l}$ de DTT $1 \mathrm{M}$ e $1 \mu \mathrm{l}$ de RNAse OUT, incubando-se por 2 minutos a $42{ }^{\circ} \mathrm{C}$. Manteve-se essa temperatura e então foi adicionado $1 \mu \mathrm{de}$ enzima Superscript II, por mais 50 minutos, seguido de mais 15 minutos à $70^{\circ} \mathrm{C}$. Em seguida foi adicionado $1 \mu l$ de enzima RNAse $H$, seguido de incubação por 20 minutos à $37^{\circ} \mathrm{C}$. As amostras do produto obtido (cDNA) foram acondicionadas em freezer $-20^{\circ} \mathrm{C}$ até o momento da amplificação (Teodorov et al., 2011).

\subsubsection{2 qPCR}

Após a transcrição reversa foi efetuado o qPCR (PCR em Tempo Real) no

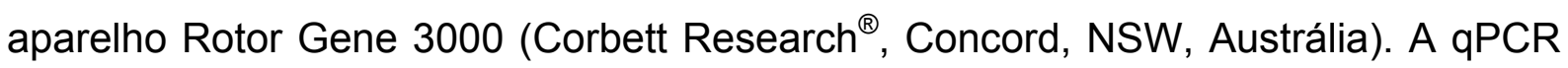
determina o Cq para cada amostra, ou seja, o ciclo de amplificação onde o acúmulo de fluorescência na amostra atinge a linha de detecção arbitrária (threshold). 0 resultado é coletado durante a fase exponencial de amplificação, que é quando a emissão de fluorescência é proporcional ao número inicial de cópias do produto amplificado, ou concentração da amostra.

Os primers senso e anti-senso foram específicos para os genes Oprm1, Oprk1 e Oprd1 em ratos e para o gene 18S como controle interno (genes com expressão similar entre os grupos experimentais). O sistema adotado em nosso laboratório para a detecção da expressão gênica foi o sistema EvaGreen ${ }^{\circledR}$ (Biotium, Inc., Hayward, CA, Estados Unidos). Neste sistema, além do par de primers, é necessária a utilização de uma sonda que, por ter uma temperatura de melting mais alta (cerca de $10^{\circ} \mathrm{C}$ de diferença), se hibridizará de forma específica com a fita template antes do par de primers. Todos os procedimentos foram realizados de acordo com as especificações do fabricante. As sequências utilizadas para a confecção dos primers foram aquelas depositadas no banco público do National Center for Biotechnology Information (NCBI, U.S. National Library of Medicine, Bethesda, MD, Estados Unidos). A empresa Applied Biosystems ${ }^{\circledR}$ (Thermo Fisher Scientific Inc., Waltham, MA, Estados Unidos) comercializa os primers e probes, sendo assim denominados: Rn00565144_m1 para Oprm1; Rn00567737_m1 para Oprk1, Rn00561699_m1 para Oprd1 e 4319413E para o gene constitutivo 18S 
ribossomal. As reações foram constituídas por $200 \mathrm{nM}$ de primers, água autoclavada estéril e 1 x EvaGreen master Mix otimizados para um volume final de $30 \mu \mathrm{l}$.

As condições de qPCR utilizadas foram aquelas consideradas as condições universais ótimas da reação pelo fabricante do aparelho, sendo: etapa $1: 50{ }^{\circ} \mathrm{C}, 2$ minutos; etapa 2: $95^{\circ} \mathrm{C}$ (desnaturação), 10 minutos; etapa 3: $95^{\circ} \mathrm{C}, 15 \mathrm{~s}$; etapa 4: $60{ }^{\circ} \mathrm{C}, 1$ minutos; etapa 5: voltar à etapa 3 por 35 vezes (para anelamento, extensão e coleta do sinal de fluorescência). O software RG-3000 (Corbett Research®, Concord, NSW, Austrália) foi utilizado para gerar a curva padrão de cada produto de amplificação, as curvas de dissociação, bem como suas análises (Livak, Schmittgen, 2001).

\subsubsection{Expressão das proteínas MOR, KOR e DOR por Western Blotting}

Após a dissecação do hipotálamo como descrito anteriormente, as amostras foram mergulhadas em $50 \mu \mathrm{l}$ de working solution (sample buffer 2 x, DTT $100 \mathrm{mM}$, PMSF $1 \mathrm{mM}$ ) e maceradas, sendo que mais $50 \mu \mathrm{l}$ de sample buffer (SDS 4\%, TRIS$\mathrm{HCl}$ pH 6,8 $120 \mathrm{Mm}$, glicerol 20\%) foram adicionados posteriormente. Em seguida, as amostras foram centrifugadas a $13.000 \mathrm{rpm}$, por 15 minutos a $4{ }^{\circ} \mathrm{C}$. O sobrenadante foi retirado cuidadosamente e colocado em microtubos, sendo armazenado em freezer $-80^{\circ} \mathrm{C}$ até o momento das análises. Para a quantificação de proteínas, foi utilizada uma curva padrão em relação a concentrações conhecidas de albumina com o reagente Bradford. As amostras foram acondicionadas em placas elisa e quantificadas em software específico (SoftMax ${ }^{\circledR}$ Pro, Molecular Devices, LLC., Sunnyvale, CA, Estados Unidos).

As frações proteicas foram separadas por eletroforese em um gel de poliacrilamida na presença de SDS, com o auxílio de minicubas verticais (Bio-Rad Laboratories, Inc., Hercules, CA, Estados Unidos). Os lisados celulares foram solubilizados em um tampão de amostras (TRIS $60 \mathrm{mM}$, glicerol 25\%, SDS 2\%, azul de bromofenol 0,1\%, $\beta$-mercaptoetanol 14,4M), de maneira a depositar a quantidade desejada de proteínas $(10 \mu \mathrm{g})$ em um volume final de $20 \mu \mathrm{l}$ por poço do gel.

A migração foi iniciada em um gel de aproximadamente $1,5 \mathrm{~cm}$ de altura (TrisBase 1,5 M, pH 8,8; SDS 10\%; acrilamida 40\%, persulfato de amônia $10 \%$ e TEMED), sob potencial de $110 \mathrm{~V}$. A eletroforese prosseguiu em um gel de separação (Tris-Base 1M, pH 8,8; SDS 10\%; acrilamida 40\%, persulfato de amônia 
$10 \%$ e TEMED), sob voltagem de $110 \mathrm{~V}$, por uma hora. A eletroforese foi conduzida em Tampão de Migração (Tris-Base 250 mM; SDS 10\%; glicina 960 mM).

A eletroforese foi interrompida quando a fronte de migração, visualizada graças ao uso do marcador kaleidoscopio (Bio-Rad ${ }^{\circledR}$ ), atingiu a porção de coloração violeta, correspondente a $40 \mathrm{Kda}$. As proteínas do gel então foram transferidas para uma membrana de nitrocelulose $\left(\right.$ Bio-Rad $^{\circledR}$ ). Para isso, o gel foi colocado em um tampão de transferência (Tris 25 mM; glicina 190 mM, metanol 10\%), assim como a membrana e o blotting paper (Bio-Rad $\left.{ }^{\circledR}\right)$. Um "sanduíche" foi produzido da seguinte maneira: uma folha de blotting paper, o gel de poliacrilamida, a membrana de nitrocelulose e uma outra folha de blotting paper. A transferência foi realizada a $100 \mathrm{~V}$ durante uma hora a $4^{\circ} \mathrm{C}$.

Após o tempo estabelecido para a transferência úmida, a membrana foi lavada em TTBS (Tris 100 mM, NaCl 150 mM, Tween 20 a 0,05\%) por 10 minutos. Em seguida, a membrana foi incubada durante uma hora em solução de TTBS acrescida de leite desnatado 5\% (p/vol), temperatura ambiente e agitação constante. Finalmente, a membrana foi incubada com anticorpo primário policlonal para os receptores opióides MOR (anti- $\mu$, 1:750, Santa Cruz Biotechnology Inc., Dallas, TX, Estados Unidos), KOR (anti-K, 1:1000, Santa Cruz ${ }^{\circledR}$ ), DOR (anti-ס, 1:500, Santa $\mathrm{Cruz}^{\circledR}$ ) diluídos em leite $3 \%$ overnight sob agitação constante a $4{ }^{\circ} \mathrm{C}$ e por um período aproximado de 17 horas.

No dia seguinte, a membrana foi lavada duas vezes com TTBS por 10 minutos cada e o anticorpo secundário anti-camundongo (Santa $\mathrm{Cruz}^{\circledR}$ ) diluído na proporção 1:10.000 foi aplicado e a membrana incubada durante uma hora em temperatura ambiente. $\mathrm{O}$ anticorpo secundário foi removido e a membrana lavada duas vezes com TTBS durante 10 minutos e uma lavagem final com TBS por 10 minutos.

Em seguida foi realizada a reação de quimioluminescência com kit ECL (Perkin Elmer ${ }^{\circledR}$ do Brasil, São Paulo, SP, Brasil) para detecção das proteínas e posterior quantificação. A membrana então foi colocada em solução do kit por um minuto para reação e imediatamente após estas foram colocadas no aparelho MyECL Imager (Thermo Fisher Scientific). Cada imagem obtida das membranas contendo as proteínas foi posteriormente avaliada e normalizada em relação à proteína constitutiva (alfa-tubulina) por meio do MyECL Imager Acquisition Software ${ }^{\circledR}$ (Thermo Fisher Scientific). 
As membranas depois foram tratadas com ácido acético a 5\%, para retirada dos anticorpos que marcaram MOR, KOR e DOR. Para isso, as membranas foram incubadas em leite $5 \%$ em TTBS por 10 minutos. Transcorrido o período as membranas foram lavadas duas vezes em TTBS, temperatura ambiente por 10 minutos e bloqueadas com leite 5\% TTBS, por uma hora em temperatura ambiente. Foi realizada então a incubação com anticorpo primário da alfa-TUBULINA (anti-aTUB, 1:30.000, Sigma ${ }^{\circledR}$ ) diluído em BSA 1\% por uma hora, temperatura ambiente, sob agitação constante. As membranas foram lavadas duas vezes em TBT-T por 5 minutos cada e então foi incubado o anticorpo secundário anti-mouse 1:6.000 (Sigma-Aldrich Brasil Ltda, São Paulo, SP, Brasil) por 45 minutos, temperatura ambiente e agitação. Finalmente, as membranas foram lavadas duas vezes em TTBS por 10 minutos, seguida de lavagem final com TBS por 10 minutos. Posteriormente, foi feita a reação ECL e submetidas à leitura no MyECL.

\subsection{Análises referentes à ninhada - Geração $F_{1}$}

A ninhada foi pesada diariamente do DPN 1 até o 21. O comprimento nasoanal dos filhotes e o peso individual dos mesmos foram avaliados nos DPN 1, 10 e 21 e a distância ano-genital foi analisada nos DPN 1 e 21. Após o DPN 21, os filhotes foram separados da mãe.

No DPN1, os neonatos foram classificados de acordo com o peso ao nascimento em: PIP (pequeno para a idade de prenhez) se o seu peso era menor que 1,7 vezes o desvio-padrão da média de peso dos filhotes do grupo controle; GIP (grande para a idade de prenhez) se o seu peso era maior que 1,7 vezes o desvio padrão da média de peso do grupo controle; e AIP (adequado para a idade de prenhez) se o peso do filhote encontra-se dentro da faixa de $\pm 1,7$ vezes o desvio padrão da média de peso dos neonatos do grupo controle (Soulimame-Mokhtari et al., 2005).

\subsubsection{Análise do desenvolvimento físico}

Os filhotes foram observados diariamente do DPN 1 ao 21 para avaliação do desenvolvimento físico segundo metodologia proposta por Smart e Dobbing (1971). 
Foram avaliados os seguintes parâmetros: idade de abertura de olhos, aparecimento de pelos, descolamento de orelhas e erupção dos incisivos.

\subsubsection{Análise do desenvolvimento sexual}

A fim de analisar o desenvolvimento sexual dos filhotes, os machos foram observados do DPN 19 ao 25 para verificação do dia da descida dos testículos, e do DPN 33 ao 45 para a observação do descolamento do prepúcio. As fêmeas foram observadas dos DPN30 a 40 para verificação da abertura do canal vaginal. Tais parâmetros são indicativos de instalação da puberdade. Todos os animais foram observados até que $100 \%$ deles apresentassem o parâmetro de desenvolvimento.

\subsection{Análises pós-desmame da geração $F_{1}$}

Realizado o desmame no DPN21, as ninhadas de cada mãe foram subdivididas em dois grupos, onde dois machos e duas fêmeas receberam dieta de ração padrão e os demais animais, dois de cada sexo, receberam dieta hiperlipídica (45\% kcal de gordura). Isso fez com que se resultasse em 4 grupos experimentais para a geração $F_{1}$, considerando a dieta fornecida às mães $\left(F_{0}\right)$, como mostra o esquema abaixo:

Figura 2 - Esquema representativo da dieta administrada aos animais $F_{1}$ após o desmame.
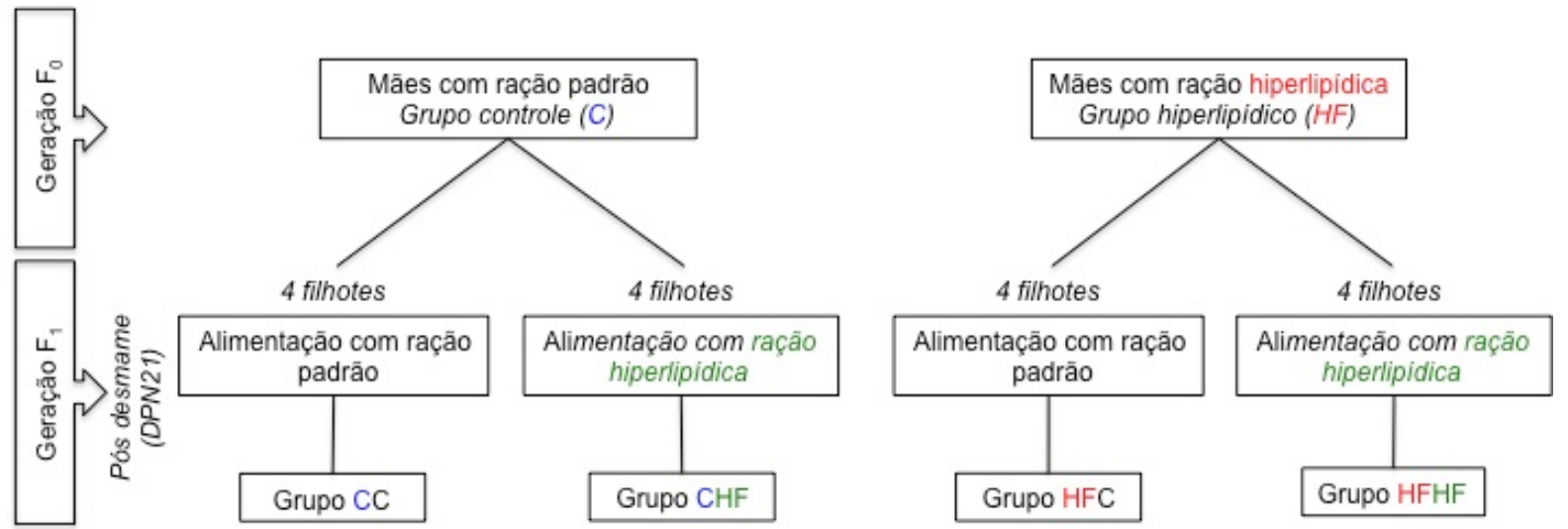

Após o desmame, 4 filhotes, sendo 2 machos e 2 fêmeas de cada ninhada, passaram a receber dieta diferente da que a mãe recebeu durante toda a gestação e lactação (grupos CHF e HFC). 
O ganho de peso corpóreo dos animais, machos e fêmeas, foi acompanhado semanalmente do DPN21 ao DPN85 ( $4^{\mathrm{a}}$ a $12^{\mathrm{a}}$ semana de vida) e a ingestão alimentar dos mesmos do DPN21 ao DPN70.

\subsubsection{Eutanásia dos filhotes nos DPN 35 e 70}

Aos 35 e 70 dias de vida pós-natal um macho e uma fêmea de cada grupo ( $n=7$ por grupo) foram pesados e sofreram eutanásia por decapitação. O soro foi coletado para realização da dosagem de colesterol total, HDL-colesterol, LDLcolesterol, triglicérides, AST e ALT. Nos animais no DPN70, também foram realizadas as dosagens dos hormônios insulina e leptina. As análises bioquímicas e hormonais foram realizadas como descrito anteriormente (vide item 3.3.6). O fígado e as gorduras retroperitoneal e perigonadal dos animais foram coletados e pesados para posterior comparação entre os grupos.

Tais análises foram realizadas para acompanhamento do desenvolvimento corporal e dos parâmetros metabólicos dos animais no período peripuberal (DPN 35) e na vida adulta (DPN 70).

\subsubsection{Teste de preferência à sacarose}

Após o DPN70, um macho e uma fêmea de cada grupo tiveram acesso a duas garrafas simultaneamente: uma contendo água, e outra com uma solução de $4 \%$ de sacarose durante 48 horas. Após 24 horas, a ordem das garrafas foi trocada aleatoriamente. O consumo de água, da solução de sacarose e o peso corporal dos animais foi medido a cada 24 horas. Os animais foram alojados individualmente e tinham ração disponível durante todo o período do teste. O consumo de água, sacarose e o total de líquido ingerido foi normalizado de acordo com o peso dos animais. A preferência à sacarose foi calculada como percentual de solução consumida em relação ao total da ingestão de líquidos durante o período (Vucetic et al., 2010). 


\subsubsection{Teste de preferência à dieta hiperlipídica}

Após o DPN75, foi fornecido a um macho e uma fêmea de cada grupo experimental ambos os tipos de dieta (padrão e hiperlipídica 45\%). As dietas foram disponibilizadas por 24 horas em 3 dias separados. Os dados do primeiro dia não foram analisados porque os animais estavam adaptando-se à nova dieta. Assim, foi usada uma média do consumo de cada ração no segundo e terceiro dias para as análises.

Foi medido o consumo da dieta padrão, da dieta rica em lipídeos e o peso corporal, sendo a ingesta normalizada em relação ao peso dos animais. A preferência à gordura foi calculada como percentual de dieta hiperlipídica consumida em relação ao total de ração ingerida (padrão e rica em lipídeos) (Vucetic et al., 2010).

\subsection{Acompanhamento do ciclo estral e acasalamento das fêmeas da geração $F_{1}$}

Do DPN70 ao 85, durante 15 dias, uma fêmea de cada um grupo foi submetida à análise da citologia vaginal, no período da manhã, para acompanhamento do ciclo estral. A duração do ciclo estral foi determinada como a média do número de dias entre uma fase estro do ciclo até o início do próximo estro (Kiss et al., 2012).

Após o acompanhamento do ciclo estral, as fêmeas foram colocadas na presença de um macho sexualmente experiente para acasalamento (em idade compatível e não utilizado anteriormente em outro momento do estudo). Durante a gestação e lactação, as fêmeas continuaram a ser alimentadas com a dieta a que vinham sendo submetidas desde o desmame, no DPN21 (grupos CC e HFC dieta padrão, e grupos CHF e HFHF dieta hiperlipídica 45\%).

\subsubsection{Análises durante a gestação e lactação (Geração $F_{1}$ )}

O peso corporal das mães foi acompanhado diariamente durante a gestação e lactação, e a ingestão calórica foi monitorada a cada três dias durante a gestação e diariamente na lactação até o DPN15. A duração da prenhez, o número de filhotes 
nascidos em cada ninhada e a proporção de machos e fêmeas na ninhada também foi avaliado.

Ademais, durante a gestação, amostras de sangue caudal foram obtidas para análise dos índices de glicemia, nos DG 0,7,14 e 21, como descrito anteriormente (vide item 3.3.1). Também foram realizados os testes de tolerância a insulina (TTI) nos dias 15 (DG15) de gestação e 6 de lactação (DPN6) e o teste de tolerância à glicose oral (TTOG) nos DG 17 e DPN 8, como previamente descrito (ver 3.3.2 e 3.3.3).

\subsubsection{Análise do comportamento materno (geração $F_{1}$ )}

O comportamento materno da geração $F_{1}$ também foi observado como foi realizado com as mães da geração $F_{0}$ (vide item 3.3.4). O comportamento materno foi gravado nos DPN5 e 10 com e sem intervenção prévia nos filhotes.

\subsubsection{Análises no desmame - Mães geração $F_{1}$}

No DPN21, foi realizado o desmame da ninhada. Em seguida, as mães sofreram eutanásia por decapitação, e tiveram o encéfalo rapidamente retirado para dissecação do hipotálamo com bisturi para posterior processamento e análise da expressão dos genes e proteínas dos receptores $\mu$, $\mathrm{k}$ e $\delta$ por qPCR e Western Blotting, como descrito nos itens 3.3.7 e 3.3.8. O sangue também foi coletado e o soro armazenado em $-20{ }^{\circ} \mathrm{C}$ para realização de análises bioquímicas e hormonais (ver 3.3.6). O fígado e as gorduras retroperitoneal e retrogonadal foram retirados e pesados para comparação entre os grupos experimentais.

\subsection{Análise da ninhada (geração $F_{2}$ )}

No dia seguinte ao parto (DPN1), a ninhada foi pesada e realizou-se a sexagem e padronização da mesma, permanecendo cada mãe com 4 filhotes fêmeas e 4 filhotes machos. Nesse dia, os neonatos foram classificados de acordo com o peso ao nascimento em pequeno, adequado ou grande para a idade de prenhez (ver 3.4). Foi realizado o acompanhamento diário do ganho de peso da ninhada durante a lactação. O acompanhamento do desenvolvimento físico dos 
filhotes, a análise do peso individual e do comprimento naso-anal nos DPN 1, 10 e 21 e análise da distância anogenital nos DPN 1 e 21 também foram realizados.

\subsection{Análises nos machos adultos}

Após o DPN70, os machos foram mantidos na mesma dieta em que estavam desde o desmame (grupos CC, CHF, HFC e HFHF) e foram submetidos a testes comportamentais.

\subsubsection{Labirinto em cruz elevado}

Os ratos foram testados durante a fase clara do ciclo. O aparato em formato de cruz consistia de 2 braços abertos opostos $(50 \mathrm{~cm}$. x $10 \mathrm{~cm}$.) e 2 braços fechados (mesmas medidas dos braços abertos com paredes de $40 \mathrm{~cm}$. de altura). Assim que o animal era colocado no centro do aparato, sempre com os olhos voltados para a parte aberta do labirinto, o experimentador deixava a sala. O comportamento do animal foi gravado durante 5 minutos, sendo as imagens obtidas por uma câmera acima do equipamento. Foram calculados o tempo total gasto em cada um dos braços abertos e fechados, assim como o número de entradas em cada um deles (Nasello et al., 1998; Walf, Frye, 2007).

\subsubsection{Comportamento sexual}

Após a realização do teste de labirinto em cruz elevado, os machos foram transferidos para uma sala onde o ciclo claro/escuro dos animais foi invertido. Eles passaram por um processo de adaptação das funções fisiológicas ao novo ciclo durante 15 dias antes de serem testado para o desempenho sexual. Cinco fêmeas também passaram por esse processo para que pudessem ser utilizadas no teste como estímulo aos machos.

No dia do teste, o macho sexualmente experimente foi posto em uma gaiola individual transparente sob iluminação vermelha durante a fase escura do ciclo. Após 5 minutos, era introduzida uma fêmea sexualmente receptiva. $O$ estro foi induzido na fêmea com uma injeção subcutânea de $1 \mathrm{mg} / \mathrm{Kg}$ de valerato de estradiol 24 horas antes do teste. Foram quantificados, durante 30 minutos, os seguintes 
parâmetros: latência para primeira intromissão e primeira ejaculação, número de intromissões até a primeira ejaculação, latência para a primeira intromissão pósejaculação, número de intromissões após a primeira ejaculação e número total de ejaculações durante o teste (Cruz-Casallas et al., 1999; Gerardin et al., 2008).

\subsubsection{Obtenção e análise de material biológico}

Após a realização dos testes comportamentais, aproximadamente no DPN120, os machos foram pesados e sofreram eutanásia por decapitação. Em seguida, o sangue foi coletado para dosagem sérica de colesterol, HDL-colesterol, triglicéride, AST e ALT, como descrito no item 3.3.6.

O peso dos órgãos do sistema reprodutor, como testículo, epidídimo, próstata, vesícula seminal cheia e vazia foi comparado entre os diferentes grupos experimentais. O fígado e a hipófise também foram coletados e pesados.

$O$ tecidos adiposo retroperitoneal e o retrogonadal foi removido e pesado. $A$ partir desses valores, e do peso corporal do animal, foi calculado o índice de gordura corporal (IGC) de acordo com a seguinte fórmula:

IGC (\%): gordura retroperitoneal $(g)+$ gordura retrogonadal $(g) \times 100$

peso corporal $(g)$

\subsection{Expressão gênica de fatores de transcrição neurais durante a gestação}

Os procedimentos a seguir foram realizados no Departamento de Neurociência da Carleton University, em Ottawa no Canadá, durante a realização do estágio sanduíche sob a supervisão do Prof. Dr. Alfonso Abizaid.

Fêmeas oriundas do laboratório Charles River (Charles River Laboratories International, Inc., St. Constant, QC, Canadá) foram colocadas na presença de um macho para acasalamento, na proporção de duas fêmeas para cada macho. O dia em que espermatozoides foram encontrados no lavado vaginal das fêmeas, foi considerado como dia 0 de gestação (DG0).

Detectada a prenhez, as fêmeas foram mantidas em gaiolas individuais e imediatamente divididas em dois grupos aleatórios: o grupo high fat $(\mathrm{n}=16)$, no qual as fêmeas receberam uma dieta com $60 \%$ de calorias oriundas de lipídeos, do DG0 até o dia da eutanásia para obtenção dos cérebros do fetos em desenvolvimento, 
como descrito a seguir; e um grupo controle $(n=15)$, que recebeu uma dieta padrão durante o mesmo período.

\subsubsection{Composição da dieta}

A dieta padrão utilizada nesse experimento era composta de $3,3 \mathrm{kcal} / \mathrm{g}$, com $70 \%$ das calorias oriundas de carboidratos. A dieta hiperlipídica era uma ração purificada, a qual possui $5,1 \mathrm{kcal} / \mathrm{g}$, sendo $60,3 \%$ das calorias originadas de gordura (18,4\% de proteínas e $21,3 \%$ de carboidratos). Sua composição era de caseína, Lcistina, maltodextrina, sacarose, banha de porco, olho de soja, celulose, mix mineral, fosfato de cálcio, mix de vitaminas, bitartarato de colina e corante alimentício azul (TD.06414, Harlan ${ }^{\mathrm{TM}}$, Harlan Laboratories, Inc., Madison, WI, Estados Unidos).

\subsubsection{Obtenção e processamento dos encéfalos dos fetos}

Quatro fêmeas de cada grupo sofreram eutanásia na câmara de $\mathrm{CO}_{2}$ nos dias 12, 14, 16 e 18 de gestação para coleta dos encéfalos em desenvolvimento por laparotomia. Para os experimentos, foi utilizada toda a cabeça dos embriões nos dias 12 e 14, enquanto que os fetos nos dias 16 e 18 tiveram o encéfalo dissecado.

Metade dos filhotes de cada mãe foram imediatamente congelados em solução TRIzol (Invitrogen ${ }^{\circledR}$ ) e armazenados em freezer $-80{ }^{\circ} \mathrm{C}$ até o momento da extração do RNA. A outra metade foi mantida em solução fixadora composta por paraformaldeído 4\% em tampão fosfato (PBS) por aproximadamente 12 horas. Em seguida, os encéfalos foram crioprotegidos com solução de $30 \%$ de sacarose em PBS e então embebidos em cola para obtenção de cortes histológicos (OCT Tissue-

Tek $^{\circledR}$, Sakura Finetek USA Inc., Torrance, CA, Estados Unidos). Os blocos foram seccionados em criostato a $20 \mu \mathrm{m}$. Os cortes foram colocados em lâmina histológica e armazenados em freezer $-80^{\circ} \mathrm{C}$ para posterior realização de imunofluorescência.

\subsubsection{Análise da expressão gênica}

A expressão gênica foi avaliada para os fatores de transcrição: Neurogenina 3 (Ngn3), Mammalian achaete scute homolog-1 (Mash1), Retinal and anterior neural fold homeobox (Rax) e SIX homeobox 3 (Six3). Também foi avaliada a expressão 
dos genes da proopiomelanocortina (POMC), do neuropeptídeo Y (NPY), do peptídeo relacionado ao Agouti (AgRP), da pro-proteína convertase 1/3 (PC1), da pro-proteína convertase 2 (PC2), do receptor de melanocortina-4 (MC4R) e do supressor da sinalização de citocina-3 (SOCS3).

\subsubsection{Ensaio da transcrição reversa (RT-PCR)}

As amostras dos fetos foram homogeneizadas em $1 \mathrm{~mL}$ de TRIzol e o RNA foi extraído de acordo com as instruções do fabricante (Invitrogen ${ }^{\circledR}$ ). Em seguida, o RNA foi transcrito reversamente utilizando o kit de síntese de cDNA iScript ${ }^{\mathrm{TM}}$ (Bio$\operatorname{Rad}^{\circledR}$ ) também de acordo com as instruções do fabricante. As amostras foram então armazenadas a $-20^{\circ} \mathrm{C}$ para uso futuro na $\mathrm{qPCR}$.

\subsubsection{PCR Quantitativa (qPCR)}

A qPCR foi realizada no equipamento CFX Connect ${ }^{T M}$ Real-Time PCR Detection System (Bio-Rad ${ }^{\circledR}$ ) usando o mix iQ SYBR Green (Bio-Rad ${ }^{\circledR}$ ). A sequência utilizada para os primers está demonstrada na tabela 1.

As condições utilizadas para a reação de PCR foram: $1^{\text {a }}$ etapa $-30 \mathrm{~s}$ a $95^{\circ} \mathrm{C}$, $2^{\mathrm{a}}$ etapa - $10 \mathrm{~s}$ a $95^{\circ} \mathrm{C}, 30 \mathrm{~s}$ a $57^{\circ} \mathrm{C}$ e então $20 \mathrm{~s}$ a $72^{\circ} \mathrm{C}$; esta etapa foi repetida 45 vezes. $3^{\mathrm{a}}$ etapa $-60 \mathrm{~s}$ a $95^{\circ} \mathrm{C} ; 4^{\mathrm{a}}$ etapa $-60 \mathrm{~s}$ a $55^{\circ} \mathrm{C}, 5^{\mathrm{a}}$ etapa $-30 \mathrm{~s}$ a $55^{\circ} \mathrm{C}$ (repetido 41 vezes). Os valores de $\mathrm{Cq}$ foram determinados automaticamente pelo CFX Manager ${ }^{\mathrm{TM}}$ Software $\left(\right.$ Bio-Rad $^{\circledR}$ ). A quantificação dos transcritos de interesse em relação ao controle interno do gene constitutivo GAPDH foi determinada usando o método do $2^{-\Delta \Delta C q}$ (Bustin et al., 2009; Schimittgen, Livak, 2008). 
Tabela 1 - Sequência dos primers utilizados.

\begin{tabular}{|c|c|c|}
\hline Gene & & Sequência \\
\hline \multirow{2}{*}{ Ngn3 } & Senso & 5'-GCAGAGCAGATAAAGCGTGC-3' \\
\hline & Antisenso & 5'-TCGCCTGGAGTAAATTGCGT-3' \\
\hline \multirow{2}{*}{ Mash1 } & Senso & 5'-TCGGCGGTCGAATACATCC-3' \\
\hline & Antisenso & 5'-CCGCCATAGAGTTCAAGTCGT-3' \\
\hline \multirow{2}{*}{$\operatorname{Rax}$} & Senso & 5'-AGCGGGACCTTCAGTTTGG-3' \\
\hline & Antisenso & 5'-CTTGGTCTTCGTGCCGTACTC-3' \\
\hline \multirow{2}{*}{ Six3 } & Senso & 5'-TCAGCAGAGTCACCGTCCAC-3' \\
\hline & Antisenso & 5'-TGGAGGTTACCGAGAGGATCG-3' \\
\hline \multirow{2}{*}{ POMC } & Senso & 5'-CCTGTGAAGGTGTACCCCAATGTC-3' \\
\hline & Antisenso & 5'-CACGTTCTTGATGATGGCGTTC-3' \\
\hline \multirow{2}{*}{ NPY } & Senso & 5'-CCCGCCCGCCATGATGCTAGG-3' \\
\hline & Antisenso & 5'-CCGCCCGGATTGTCCGGCTTG-3' \\
\hline \multirow{2}{*}{ AgRP } & Senso & 5'-AGAGTTCTCAGGTCTAAGTCT-3' \\
\hline & Antisenso & 5'-CTTGAAGAAGCGGCAGTAGCACGT-3' \\
\hline \multirow{2}{*}{ PC1 } & Senso & 5'-CGAAGAGGCAGTTTGTCAATGAATGG-3' \\
\hline & Antisenso & 5'-ATCATCAGATAACCTCTTAGTG-3' \\
\hline \multirow{2}{*}{ PC2 } & Senso & 5'-CCTTTGCAGAAGGCCTGTACCAC-3' \\
\hline & Antisenso & 5'-AGCCCAGGAGTCCCGTCAGCTTGC-3' \\
\hline \multirow{2}{*}{ MC4R } & Senso & 5'-AACATTCTAGTGATCGTGGC-3' \\
\hline & Antisenso & 5'-CATAATGTTATGGTACTGGAGCGCG-3' \\
\hline \multirow{2}{*}{ socs3 } & Senso & 5’-CTTTACCACCGACGGAACCT-3' \\
\hline & Antisenso & 5'-CCGTTGACAGTCTTCCGACA-3' \\
\hline \multirow{2}{*}{ GAPDH } & Senso & 5'-AAGATGGTGAAGGTCGGTGT-3' \\
\hline & Antisenso & 5'-CTTGCCGTGGTAGAGTCAT-3' \\
\hline
\end{tabular}

\subsubsection{Imunofluorescência}

Os cortes dos encéfalos obtidos dos fetos no $18^{\circ}$ dia de gestação foram processados para realização de imunofluorescência e marcação dos neurônios POMC de acordo com o descrito a seguir (Lamont et al., 2012; MacKay et al., 2013).

As lâminas foram lavadas em PBS e incubadas a temperatura ambiente por 30 minutos em uma solução composta de $1 \%$ de peróxido de hidrogênio v/v. Logo 
após, foram novamente lavadas em PBS e encubadas por 30 minutos em temperatura ambiente na solução de bloqueio, constituída por $0,3 \%$ de Triton $\mathrm{X}-100$ em PBS e soro albumina bovina (BSA). Seguida a fase de bloqueio, foi colocado diretamente sobre os cortes o anticorpo anti-POMC feito em coelho (1:2500; Phoenix Pharmaceuticals Inc, Burlingame, CA, Estados Unidos). As lâminas foram encubadas por 24 horas em temperatura ambiente e então lavadas com PBS. Seguidamente, foi adicionado aos cortes o anticorpo secundário feito em burro, anticoelho, Alexa flúor 488 (1:200; Life Technologies ${ }^{\circledR}$, Thermo Fisher Scientific Inc.) durante uma hora em temperatura ambiente, diluído em BSA e PBS. Após a incubação do anticorpo, as lâminas foram lavadas em PBS e cobertas com lamínula e meio específico para imunofluorescência. Os cortes foram analisados em objetivas de x20 usando um microscópio Olympus BX61 (Olympus Corporation, Center Valley, PA, Estados Unidos) acoplado a uma unidade de disco de varredura confocal Olympus DSU.

\subsection{Análise estatística}

Para todos os dados foi estabelecido limite mínimo de significância de 95\% $(p<0,05)$. As análises estatísticas foram realizadas por meio do programa GraphPad Prism 5.0 (GraphPad Software Inc., La Jolla, CA, Estados Unidos) ou SPSS Statistics (SPSS Inc., Chicago, IL, Estados Unidos). O test t de Student foi utilizado para análise do desenvolvimento físico e sexual dos filhotes da geração $F_{1} e$ comparações entre o peso dos órgãos, área sob a curva (AUC), análises bioquímicas e expressão gênica e protéica dos receptores opióides para a geração $F_{0}$, e parâmetros relacionados à gestação como tamanho da ninhada e proporção de machos e fêmeas nascidos (grupos C e HF). Para a avaliação dos mesmos parâmetros para a Geração $F_{1}$ (grupos CC, CHF, HFC e HFHF), a ANOVA de uma via foi realizada com o pós-teste de Tukey. ANOVA de duas vias, com os parâmetros de tempo e grupo como variáveis, seguida pelo teste de Bonferroni foi realizada para avaliar o efeito do tempo e do tratamento (dieta hiperlipídica) na mudança no peso corpóreo materno durante a prenhez e lactação, ingestão de alimento materna durante a prenhez, ganho de peso da ninhada ao longo da lactação, curvas glicêmicas do TTI e TTG para todas as gerações. Para os dados de comportamento materno foram utilizados ANOVA de duas vias com pós-teste de 
Bonferroni. Para dados não paramétricos foi utilizado o teste de Kruskal-Wallis, seguido pelo teste $U$ de Mann-Whitney. O teste exato de Fisher foi utilizado na avaliação de presença ou ausência de comportamento materno total (CMT), na classificação dos filhotes de acordo com o peso ao nascimento e na duração da prenhez. O peso corpóreo individual, comprimento e distância ano-genital dos filhotes foi avaliado por meio da ANOVA de duas vias. Foi utilizada ANOVA de uma via para os testes de preferência à sacarose e à gordura. Para as análises comportamentais e de peso dos machos adultos, também foi utilizada ANOVA de uma via seguida pelo teste de Tukey. ANOVA de duas vias foi utilizada para avaliar os dados de expressão gênica dos fatores de transcrição neurais durante a gestação, sendo o tempo e a dieta as variáveis analisadas. 
"Viver é a coisa mais rara do mundo. A maioria das pessoas apenas existe." Oscar Wilde

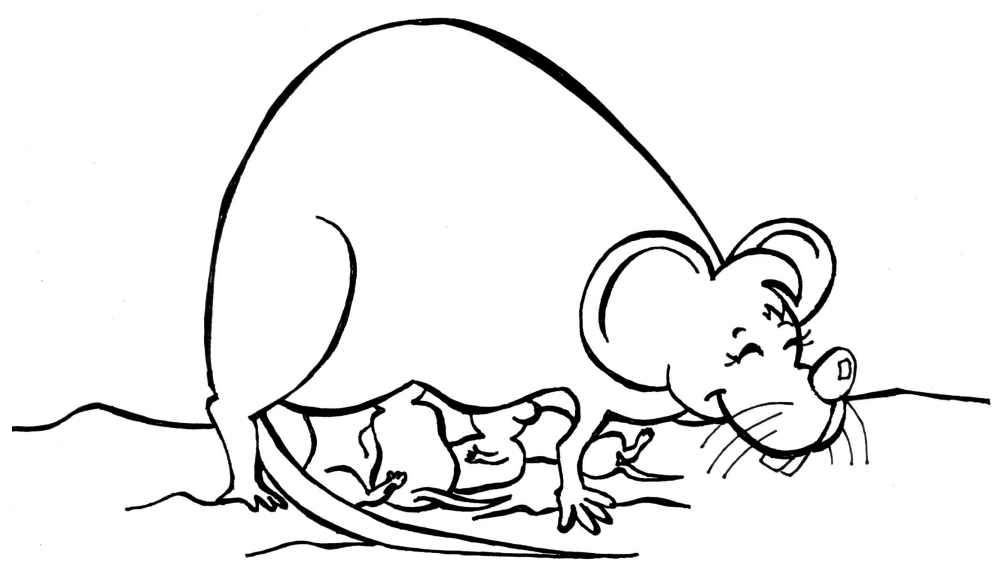


Para melhor compreensão do estudo, os resultados serão apresentados separadamente em subseções. Inicialmente, serão mostrados os resultados observados nas mães da geração $F_{0}$ (grupos $C$ e HF - ver seção 4.1); na segunda parte, serão apresentados os dados dos filhotes da geração $F_{1}$ até a vida adulta, no DPN70 (grupos CC, CHF, HFC e HFHF - ver seção 4.2); em seguida, os dados das mães da geração $F_{1}$ (grupos $\mathrm{CC}, \mathrm{CHF}, \mathrm{HFC}$ e HFHF) e os parâmetros de desenvolvimento físico acompanhados nos filhotes (geração $F_{2}-$ ver 4.3). A seguir na seção 4.4, serão apresentados os dados obtidos de testes comportamentais realizados nos machos da geração $F_{1}$ após o DPN70, e por último, os dados moleculares obtidos durante o estágio realizado no exterior (Carleton University, Canadá - ver 4.5).

\subsection{Mães Geração $F_{0}$}

A figura 3 mostra o peso das mães da geração $F_{0}$ durante a gestação. Não houve diferença estatisticamente significante entre os grupos, porém, o efeito da interação grupo $x$ tempo foi significante $(p=0,0024 ; F(21,357)=2,165)$, indicando que os grupos responderam diferentemente ao longo do tempo. Como esperado, as ratas ganharam peso durante a gestação $(p<0,0001 ; F(21,357)=715,9)$. Entretanto, em relação à ingestão de ração durante a gestação, as fêmeas do grupo HF ingeriram mais calorias quando comparadas ao grupo controle $(p=0,0012 ; F(1,17)=$ $15,29)$, como mostra a figura 4 . Também houve efeito significante de tempo, como esperado $(p<0,0001 ; F(6,96)=14,56)$.

A figura 5 mostra os níveis glicêmicos durante a gestação nos dias $0,7,14$ e 21 nas fêmeas dos grupos C e HF. O efeito do tempo também se mostrou significativo $(p<0,001 ; F(3,51)=62,3)$, entretanto não houve diferenças entre os grupos. 
Figura 3 - Acompanhamento do peso corporal absoluto $(g)$ das mães geração $F_{0}$ durante a gestação.

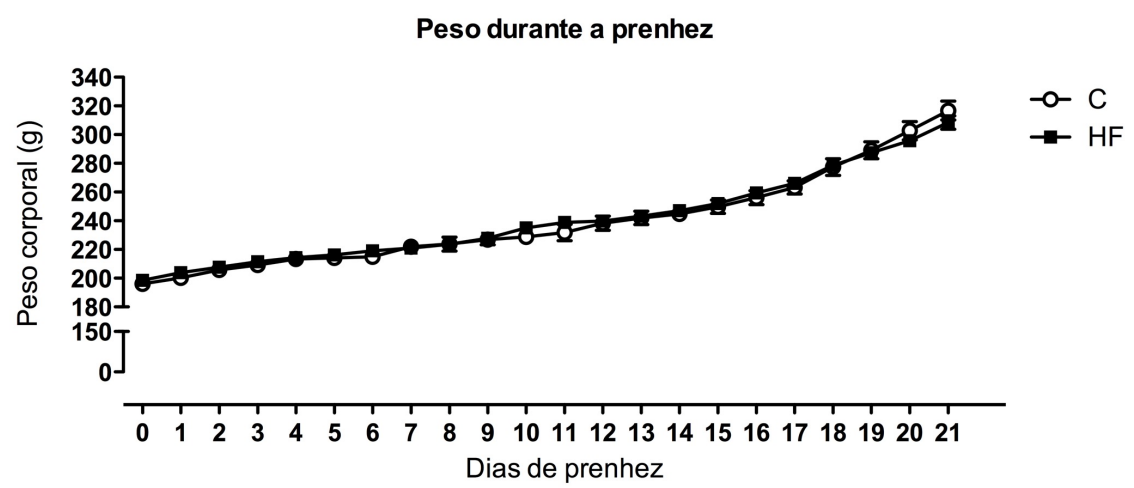

Os dados são expressos em média \pm E.P.M. C (controle): $n=9$; HF (hiperlipídica): $n=10$. ANOVA de duas vias. Efeito de interação tempo $x$ grupo e do tempo significantes, $p<0,05$.

Figura 4 - Acompanhamento da ingestão em $\mathrm{kcal} / \mathrm{Kg}$ de peso corporal durante a gestação das mães $F_{0}$.

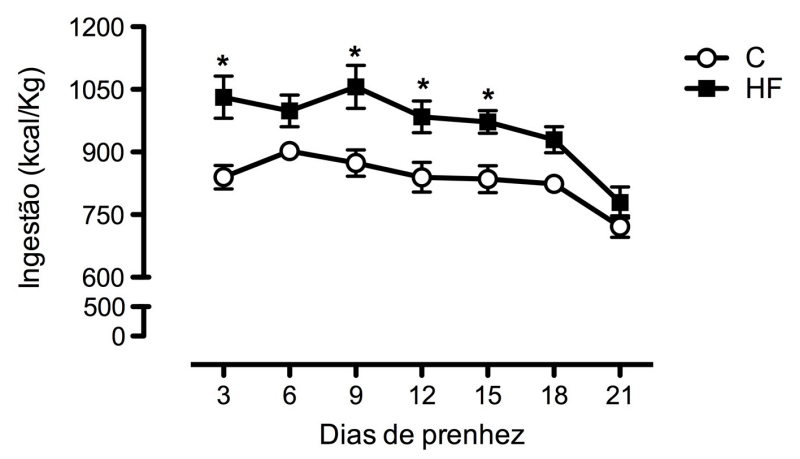

Os dados são expressos em média \pm E.P.M. C (controle): $n=9$; HF (hiperlipídica): $n=10$. ANOVA de duas vias com pós-teste de Bonferroni. Efeito do tempo significante, $p<0,0001$; efeito de grupo significante, $p<0,05 .{ }^{*} p<0,05$ comparado ao grupo $C$.

Figura 5 - Níveis glicêmicos nos dias $0,7,14$ e 21 de gestação das mães $F_{0}$.

Glicemia durante a prenhez

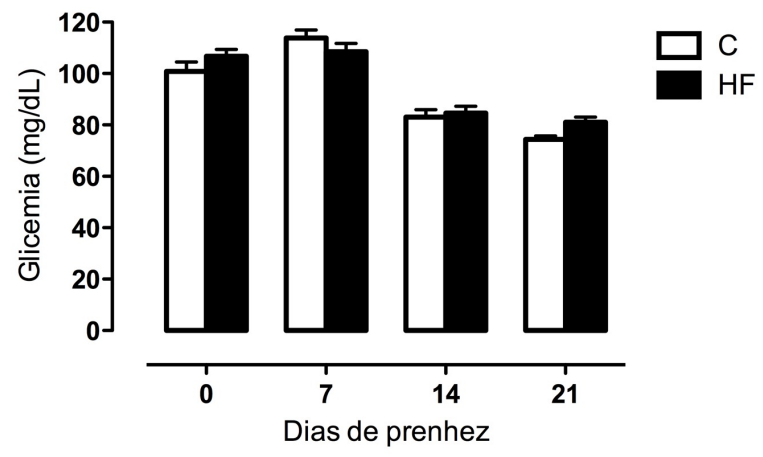

Os dados são expressos em média \pm E.P.M. C (controle): $n=9$; HF (hiperlipídica): $n=10$. ANOVA de duas vias. Efeito do tempo significante, $p<0,001$.

No DG 15, foi realizado o teste de tolerância à insulina (TTI), que não apresentou diferença significante entre os grupos, porém houve efeito significante do 
tempo ( $p=0,0017 ; F(5,85)=4,252$ ), o que indica que os animais de ambos os grupos responderam à aplicação da insulina (Figura 6A). No teste de tolerância oral à glicose (TTOG) realizado no DG 17, o efeito do tempo também se mostrou aparente $(p<0,0001 ; F(5,80)=33,44)$ e houve uma tendência a uma diferença significante entre grupos $(p=0,077 ; F(1,17)=3,568)$ (Figura $6 B$ ). Tanto no TTI como no TTOG, ambos os grupos restabeleceram os níveis glicêmicos iniciais aos 120 minutos de teste. Porém, a área sob a curva (AUC), que indica a habilidade do animal lidar com a sobrecarga de glicose durante o período de duas horas, apresentou-se maior nos animais do grupo $\mathrm{HF}$, como indica a figura $6 \mathrm{C}$, mostrando que as fêmeas com dieta rica em lipídeos possuem maior dificuldade na metabolização da glicose administrada, $p<0,03$.

Figura 6 - Teste de tolerância a insulina (TTI), teste de tolerância à glicose oral (TTOG) e área sob a curva do TTOG dos realizados durante a gestação das mães $F_{0}$.
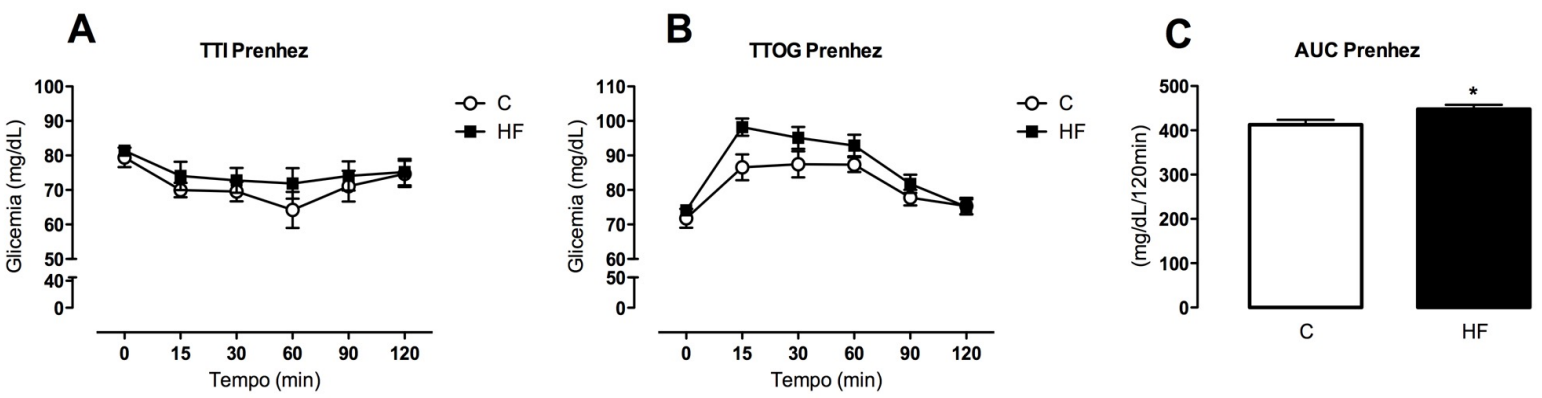

Os dados são expressos em média \pm E.P.M. $C$ (controle): $n=9$; HF (hiperlipídica): $n=10$. A. TTI realizado no DG15, ANOVA de duas vias, efeito de tempo significante, $p<0,01$. B. TGG realizado no DG17, ANOVA de duas vias, efeito de tempo significante, $p<0,0001$. C. Área sob a curva do teste de tolerância à glicose; teste $T$ de Student, ${ }^{*} p<0,05$ comparado ao grupo controle.

O acompanhamento do peso corporal das fêmeas foi realizado diariamente do dia seguinte ao parto, DPN1, ao fim da lactação, no DPN21, como mostra a figura 7. O tempo exerceu efeito significante sobre o peso das fêmeas $(p<0,0001$; $F(20,340)=49,39)$, assim como houve um interação significante de efeito grupo $x$ tempo $(p<0,0001 ; F(20,340)=6,634)$ indicando que os animais de cada grupo responderam de forma diferente ao longo dos dias. Ainda, houve uma diferença significante entre os grupos ( $p=0,0066 ; F(1,17)=9,583)$, sendo que o grupo HF ganhou menos peso durante a lactação quando comparado ao grupo controle, principalmente após o $13^{\circ}$ dia de lactação. Porém, essa diferença se extinguiu no dia do desmame (DPN21). 
Referindo-se ao consumo de ração diário durante a lactação em relação ao peso corporal da fêmea, o tempo exerceu um efeito significante sobre a ingestão alimentar $(p<0,0001 ; F(14,238)=68,14)$, sendo que as mães de ambos os grupos aumentam consideravelmente a quantidade de calorias ingeridas durante esse período (Figura 8). Entretanto, também houve um diferença significante de grupo ( $p$ $=0,0013 ; F(1,17)=14,84)$, onde as mães do grupo HF ingerem mais calorias. $\mathrm{O}$ acompanhamento do consumo alimentar da mãe foi realizado até o DPN15, uma vez que após esse dia os filhotes também passam a alimentar-se da ração.

Figura 7 - Acompanhamento do peso corporal das mães da geração $F_{0}$ durante a lactação.

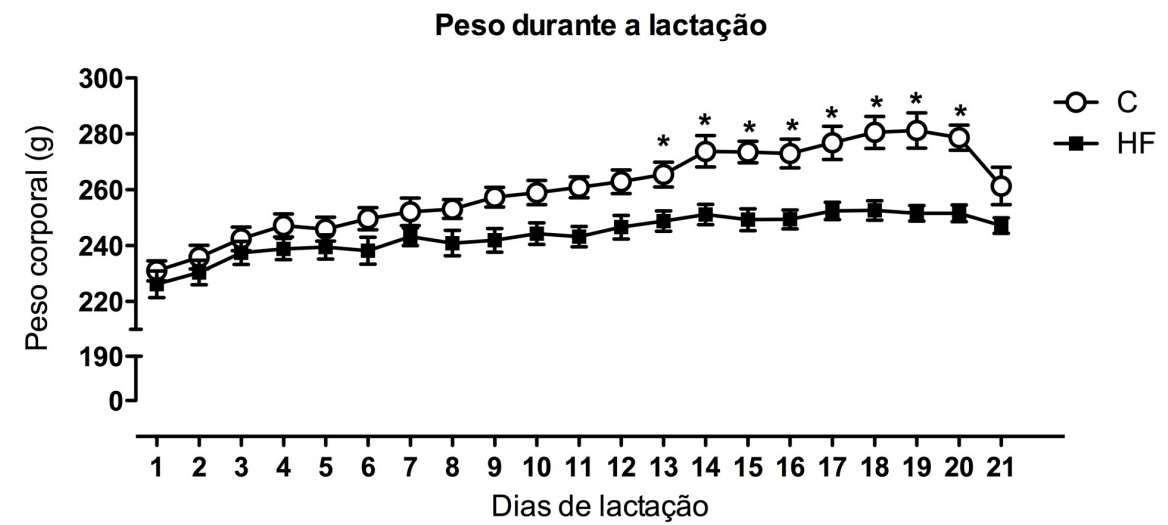

Os dados são expressos em média \pm E.P.M. C (controle): $n=9$; HF (hiperlipídica): $n=10$. ANOVA de duas vias. Efeito significante de tempo, $p<0,0001$. Efeito significante de interação grupo $x$ tempo, $p<0,0001$. Efeito significante de grupo, $p<0,0001$. ${ }^{*} p<0,05$ comparado ao grupo controle.

Figura 8 - Acompanhamento da ingestão alimentar das lactantes da geração $\mathrm{F}_{0}$.

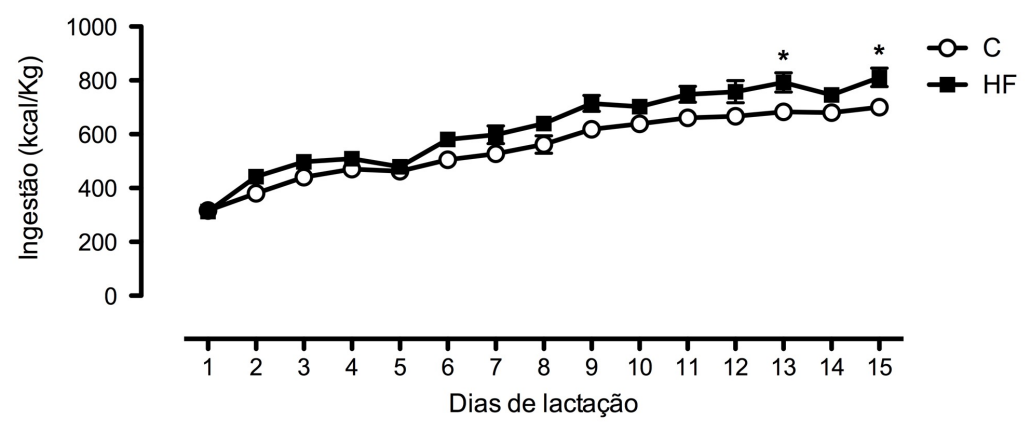

Os dados são expressos em média \pm E.P.M. C (controle): $n=9$; HF (hiperlipídica): $n=10$. ANOVA de duas vias com pós-teste de Bonferroni. Efeito significante de tempo, $p<0,0001$. Efeito significante de grupo, $p<0,01 .{ }^{*} p<0,05$ comparado ao grupo controle.

Semelhante ao que acontece durante a gestação, o TTI durante a lactação não apresentou diferenças entre os grupos na resposta à injeção de insulina (Figura $9 A)$, havendo o efeito significante de tempo $(p<0,0001 ; F(5,85)=14,38)$, o que indica 
que insulina continua exercendo seu efeito. Ao final do teste, os níveis glicêmicos basais haviam se restabelecido $(p>0,05)$.

Por outro lado, o TTOG durante a lactação mostrou que as fêmeas do grupo HF possuem maior dificuldade em lidar com a glicose administrada, como mostra a figura 9B. Houve efeito significante de grupo $(p=0,0006 ; F(1,17)=17,71)$ mostrando que as glicemias das ratas HF eram maiores que aquelas observadas no grupo controle aos 15 e 30 minutos de teste $(p<0,01)$. Houve também efeito significante de tempo $(p<0,0001 ; F(5,85)=27,31)$ e da interação tempo $\times$ grupo $(p=0,036 ; F(5,85)=$ 2,514). A área sob a curva do TTOG (AUC) apresentou-se maior nos animais do grupo HF $(p<0,001)$, como mostrado na figura $9 \mathrm{C}$.

Figura 9 - Teste de tolerância à insulina (TTI), teste de tolerância oral à glicose (TTOG) e área sob a curva do TTOG das lactantes da geração $F_{0}$.
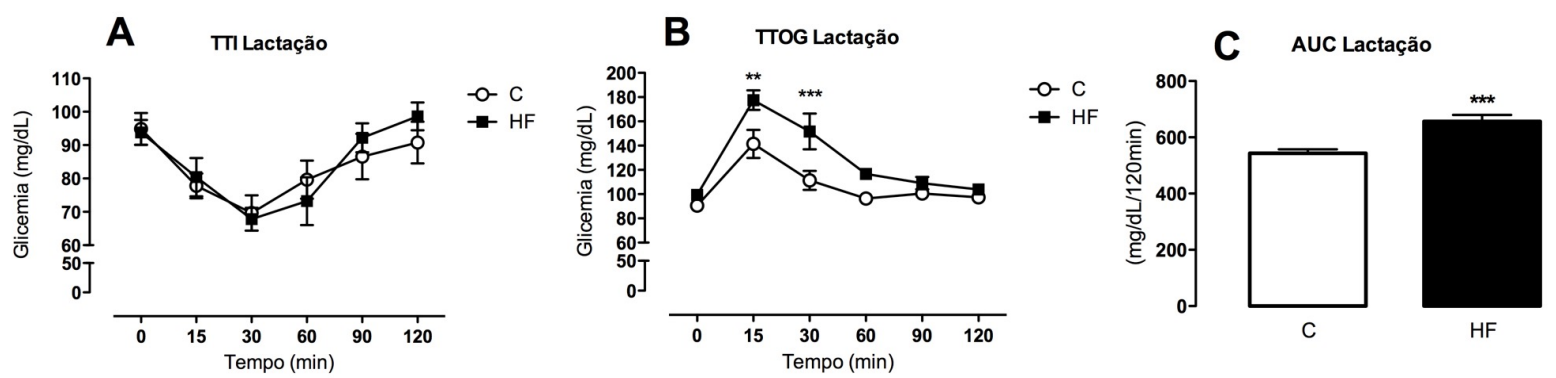

Os dados são expressos em média \pm E.P.M. C (controle): $n=9$; HF (hiperlipídica): $n=10$. A. TTI realizado no DPN6, ANOVA de duas vias, efeito de tempo significante, $p<0,0001$. B. TGG realizado no DPN8, ANOVA de duas vias. Efeito de tempo significante, $p<0,0001$, efeito interação tempo $x$ grupo significante, $p<0,05$. Efeito e grupo significante, $p<0,001$. C. Área sob a curva (AUC) do teste de tolerância à glicose; teste $t$ de Student. ${ }^{* *} p<0,01 e^{* * *} p<0,001$ comparados ao grupo controle.

Em relação a gestação, a maioria das mães em ambos os grupos pariram aos 21 dias de prenhez, como mostra a figura 10A. Não houve diferenças significantes entre o número de filhotes nascidos em cada ninhada (Figura 10B). Em relação ao sexo dos filhotes, $42,68 \%$ dos filhotes do grupo controle eram machos, sendo $51,48 \%$ no grupo HF, não apresentando diferenças estatísticas entre os grupos (Figura 10C). 
Figura 10 - Duração da prenhez, número de filhotes e proporção de machos e fêmeas nas mães $F_{0}$.

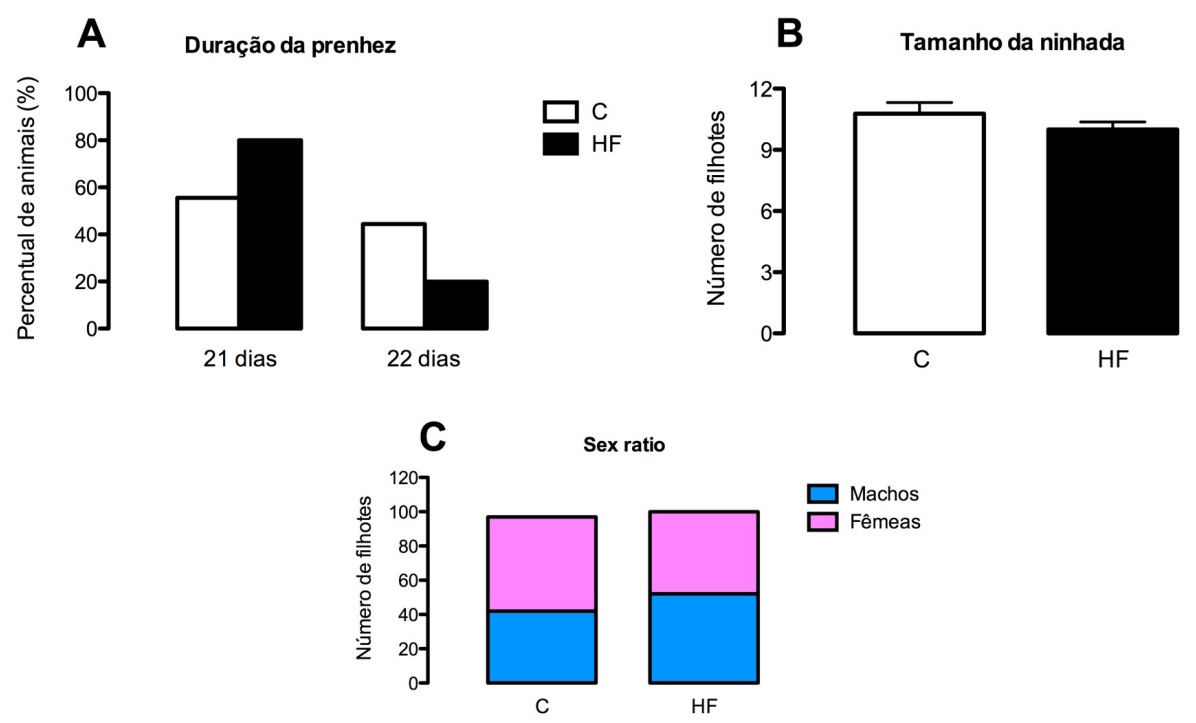

Os dados são expressos em média \pm E.P.M. C (controle): $n=9$; HF (hiperlipídica): $n=10$. A. Percentual de animais que tiveram o parto aos 21 ou 22 dias de gestação, Teste de Fisher. B. Número de filhotes paridos, Teste $T$ de Student. C. Proporção de machos e fêmeas nascidos em cada ninhada, Teste T de Student.

\subsubsection{Comportamento materno - Geração $F_{0}$}

Dois tipos de análises distintas foram realizadas para avaliar 0 comportamento materno. A seguir, são apresentados os dados dos testes de 30 minutos de duração realizados no DPN5 e 10.

Não houve diferenças estatisticamente significantes na latência para a busca do $1^{\circ}, 5$ e $8^{\circ}$ filhotes como mostra a figura 11. Entretanto, houve uma interação tempo x grupo na latência para busca do $1^{\circ}$ e $5^{\circ}$ filhotes $(p=0,017 ; F(1,17)=7,008$ e $p=0,031 ; F(1,17)=5,529$ respectivamente). Esse resultado nos levou a avaliar a diferença entre as latências para busca de cada um desses filhotes no DPN 5 e 10 (Figura 12), e esta análise revelou que enquanto no grupo controle as mães reduziram o tempo para busca dos filhotes, as mães do grupo HF aumentaram significativamente esse tempo ( $p<0,05$, Teste $t$ de Student). Isso também acontece na busca do $8^{\circ}$ e último filhote, $p<0,05$ (Figura 12C). 
Figura 11 - Latência para busca do $1^{\circ}, 5^{\circ}$ e $8^{\circ}$ filhote nos testes de comportamento materno no DPN5 e 10 das mães da geração $F_{0}$.
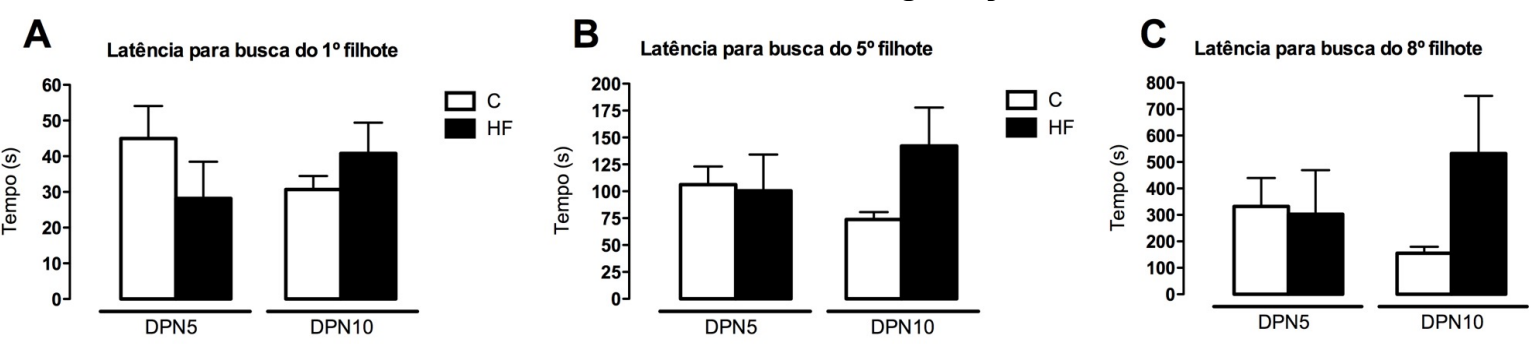

Os dados são expressos em média \pm E.P.M. C (controle): $n=9$; HF (hiperlipídica): $n=10$. A. Latência para busco do $1^{\circ}$ filhote. ANOVA de duas vias. Efeito de interação tempo $X$ grupo significante, $p<0,05$. B. Latência para a busca do $5^{\circ}$ filhote. ANOVA de duas vias. Efeito de interação tempo $X$ grupo significante, $p<0,05$. C. Latência para busca do $8^{\circ}$ e último filhote.

Figura $12-\Delta$ de variação de latência para a busca do $1^{\circ}, 5^{\circ}$ e $8^{\circ}$ filhotes das mães da geração $F_{0}$.

A $\Delta$ Latência para busca do $1^{\circ}$ filhote

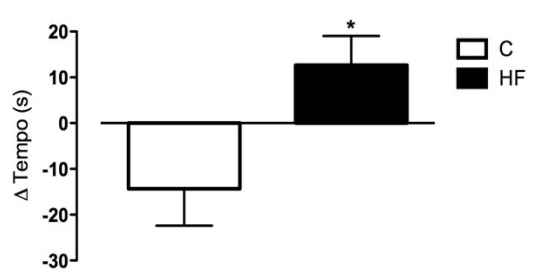

B Latência para busca do $5^{\circ}$ filhote

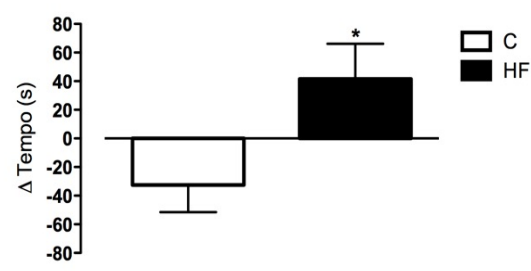

C Latência para busca do $8^{\circ}$ filhote

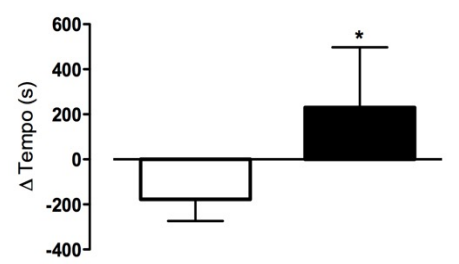

Os dados são expressos em média \pm E.P.M. C (controle): $n=9 ;$ HF (hiperlipídica): $n=10$. A. Diferença entre a latência para a busca do $1^{\circ}$ filhote no DPN 10 e no DPN5. B. Diferença entre a latência para a busca do $5^{\circ}$ filhote no DPN 10 e no DPN5. Teste $t$ de Student. C. Diferença entre a latência para a busca do $8^{\circ}$ filhote entre o DPN10 e 5. Teste de Mann Whitney. * $p<0,05$ comparado ao grupo $\mathrm{C}$.

A figura 13 mostra o número de buscas aos filhotes (quantas vezes a mãe os recolhe ao ninho), o tempo gasto fazendo selfgrooming, o tempo gasto agrupando os filhotes e o tempo em que a mãe passa lambendo seus filhotes (grooming dos filhotes). Não houve diferença entre esses parâmetros para as mães $F_{0}$. No entanto, o grupo HF que demonstrou uma tendência de aumento no tempo gasto realizando selfgrooming no DPN 10 quando comparado ao grupo $C(p=0,0776 ; F(1,17)=$ 3,529).

As mães de ambos os grupos passam mais tempo fora do ninho no DPN 5 (efeito de tempo significante, $p=0,02 ; F(1,17)=7,025)$, entretanto não há diferença significante no parâmetro de construção de ninho, como mostra a figura 14. 
Figura 13 - Parâmetros de número de buscas aos filhotes $(A)$, tempo gasto realizando selfgrooming $(B)$, tempo gasto agrupando os filhotes $(C)$ e tempo total lambendo os filhotes (D).
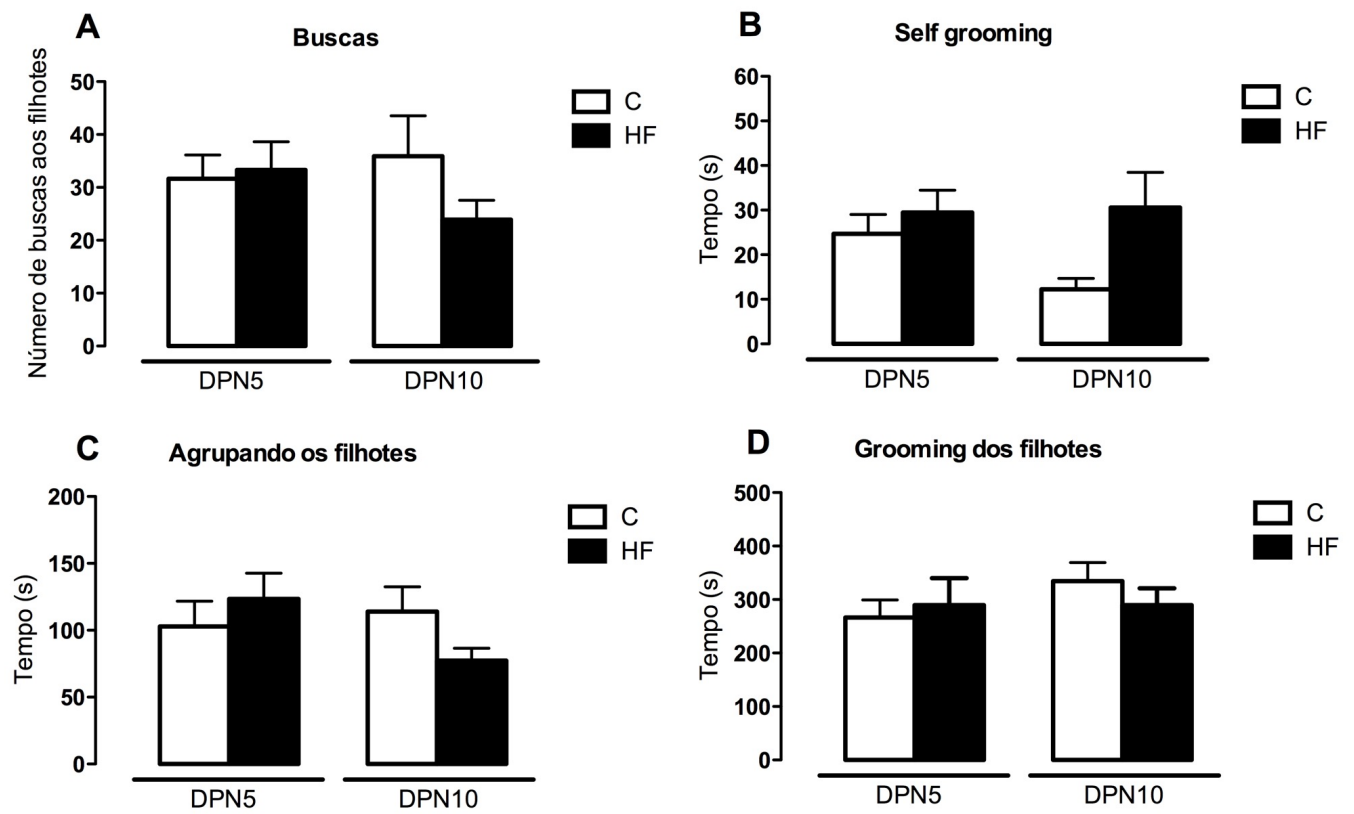

Os dados são expressos em média \pm E.P.M. C (controle): $n=9$; HF (hiperlipídica): $n=10$. ANOVA de duas vias.

Figura 14 - Tempo gasto pelas mães da geração $F_{0}$ sem cuidados destinados aos filhotes (fora do ninho) e tempo gasto construindo o ninho.
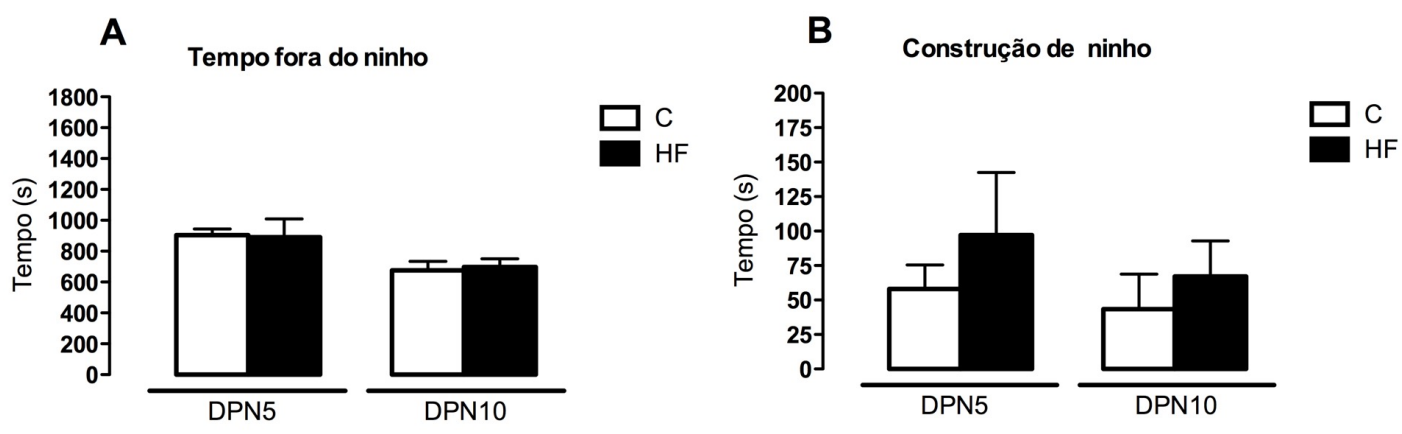

Os dados são expressos em média \pm E.P.M. C (controle): $n=9$; HF (hiperlipídica): $n=10$. ANOVA de duas vias. A. Tempo gasto fora do ninho. Efeito significante de tempo, $p<0,05$. B. Tempo gasto construindo os ninhos.

Os parâmetros de tempo gasto amamentando 4 ou menos filhotes e 5 ou mais filhotes, ambos sem posição de cifose, não apresentaram diferenças estatisticamente significantes (Figuras 15A e 15B). Entretanto, o tempo gasto pelas mães realizando crouching (amamentação em posição de cifose) foi maior em ambos os grupos no DPN10 ( $p=0,003 ; F(1,17)=11,92)$ como mostra a figura 15C. A figura 15D mostra que percentual de mães que realizaram o comportamento 
materno total também foi maior em ambos os grupos no DPN10 ( $p=0,0243$, $F(1,2)=20,43)$.

Figura 15 - Tempo gasto pelas mães da geração $F_{0}$ amamentando 4 ou menos filhotes (A), 5 ou mais filhotes (B), tempo gasto em crouching (C) e percentual de mães que realizaram CMT (D).
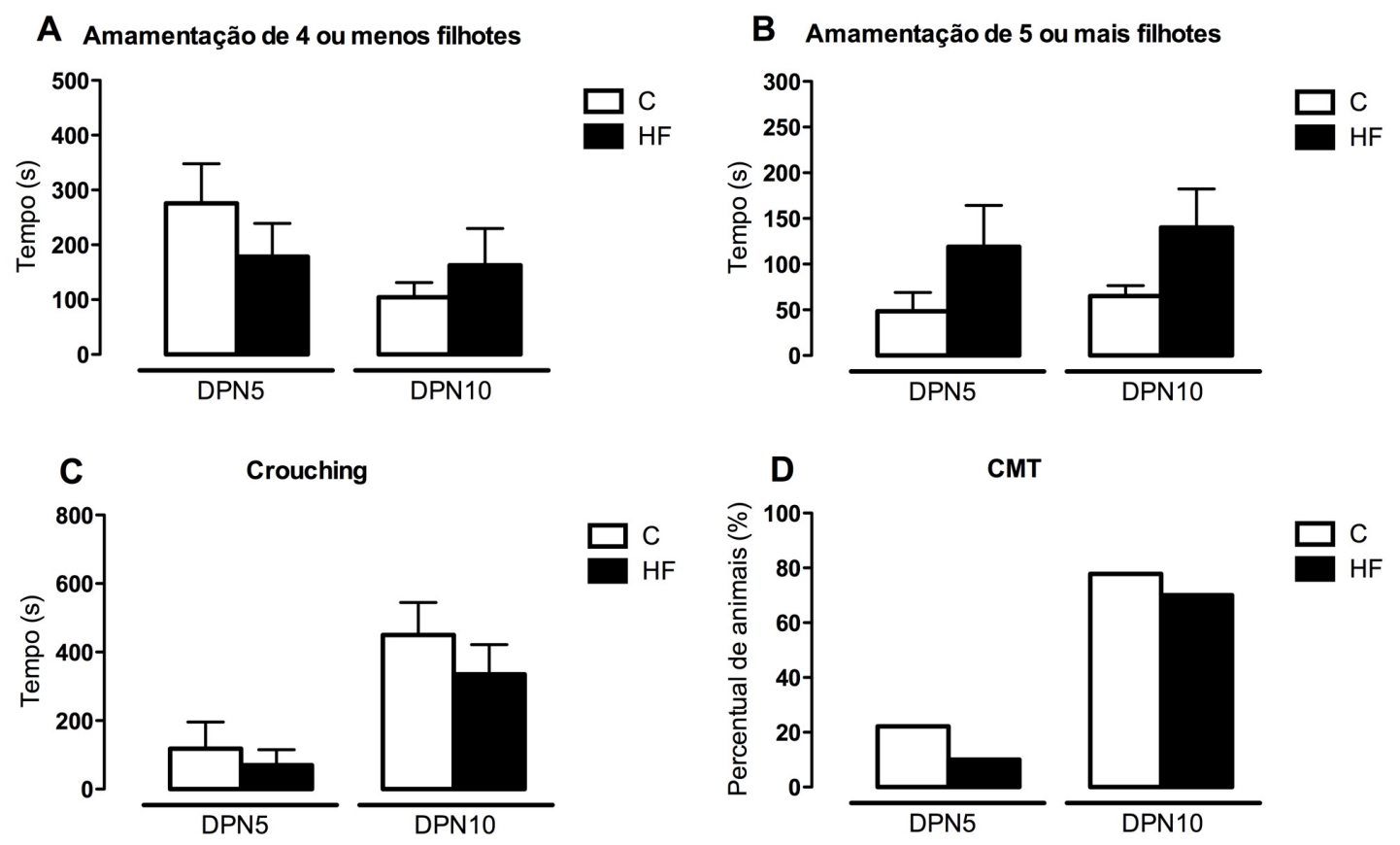

Os dados são expressos em média \pm E.P.M. C (controle): $n=9$; HF (hiperlipídica): $n=10$. ANOVA de duas vias. $C$ e $D$ apresentam efeito de tempo significante, $p<0,05$. CMT: comportamento materno total.

A seguir, são apresentados os dados do comportamento materno filmado sem intervenção prévia nas mães, por 6 horas consecutivas.

As fêmeas de ambos os grupos passam mais tempo fora do ninho no DPN10 (diferença significante de tempo $p=0,039 ; F(1,17)=4,951$ ), não havendo diferenças no número de vezes que elas visitam o ninho (Figura 16A e B). O dia da lactação interfere no tempo em que as mães gastam agrupando seus filhotes, sendo que a forma em que cada grupo responde nesses dias é diferente (efeito significante de tempo $p=0,0452 ; F(1,17)=4,671$; efeito da interação tempo $\times$ grupo significante $p=0,0254 ; F(1,17)=6,007$ - Figura 16C). As fêmeas gastam mais tempo construindo o ninho no DPN5 (efeito significante de tempo ( $p=0,0265 ; F(1,17)=5,901$ ), sendo que no grupo HF esse tempo é maior quando comparado ao grupo controle (efeito de grupo significante $p=0,0008 ; F(1,17)=16,58)$. 
Figura 16 - Parâmetros de comportamento materno avaliados durante 6 horas consecutivas nas lactantes da geração $\mathrm{F}_{0}$.

A Fora do ninho
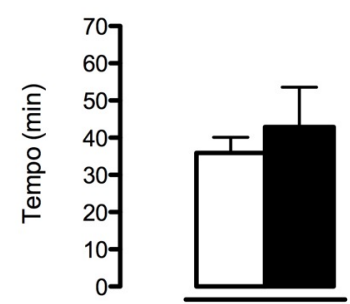

DPN5

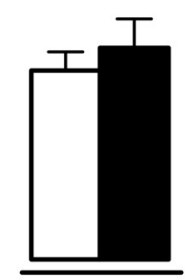

DPN10

B Número de visitas ao ninho

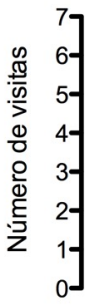

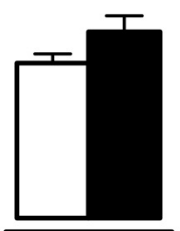

DPN5

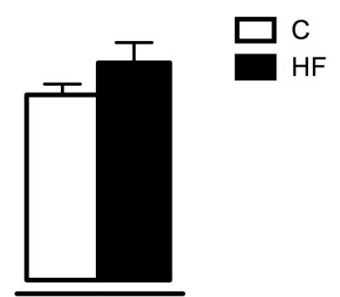

DPN10

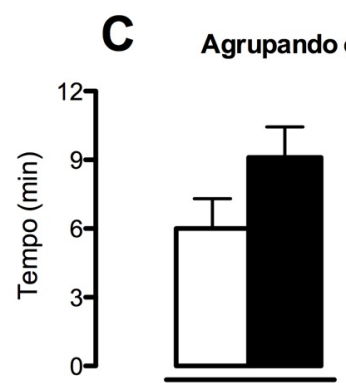

DPN5

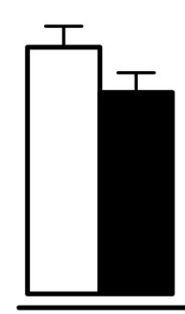

DPN10

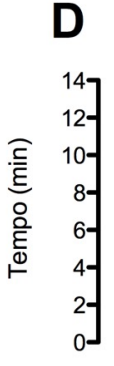

Construção de ninho

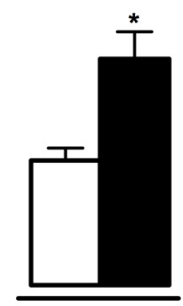

DPN5

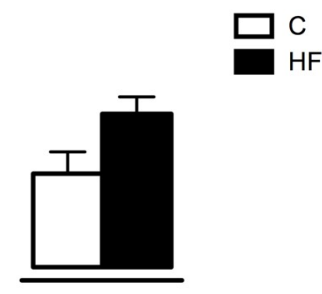

DPN10

Os dados são expressos em média \pm E.P.M. C (controle): $n=9$; HF (hiperlipídica): $n=10$. A. Tempo gasto fora do ninho, efeito significante de tempo, $p<0,05$. B. Números de vezes que a fêmea saiu $e$ voltou ao ninho. C. Tempo utilizado para agrupar os filhotes no ninho, efeito significante de tempo, $p<0,05$; efeito da interação tempo $x$ grupo significante, $p<0,05$. D. Tempo utilizado para construir o ninho, efeito significante de tempo, $p<0,05$, efeito significante de grupo, $p<0,001$. ANOVA de duas vias seguida pelo teste de Bonferroni. * $p<0,01$ comparado ao grupo $C$ no DPN5.

As lactantes passam menos tempo realizando selfgrooming e grooming dos filhotes no DPN10, como mostra a figura 17A e B (efeito de tempo significante $p=0,0037 ; F(1,17)=11,29$ e $p=0,0142 ; F(1,17)=7,459$ respectivamente). As mães do grupo HF gastam menos tempo na posição de cifose amamentando os filhotes (efeito significante de grupo $p=0,0282 ; F(1,17)=5,755)$, porém não há diferença entre os grupos quando a amamentação ocorre em qualquer outra posição que a rata assuma (Figura 17C e D). 
Figura 17 - Selfgrooming, grooming dos filhotes, tempo amamentando em cifose e em outras posições - mães $F_{0}$.
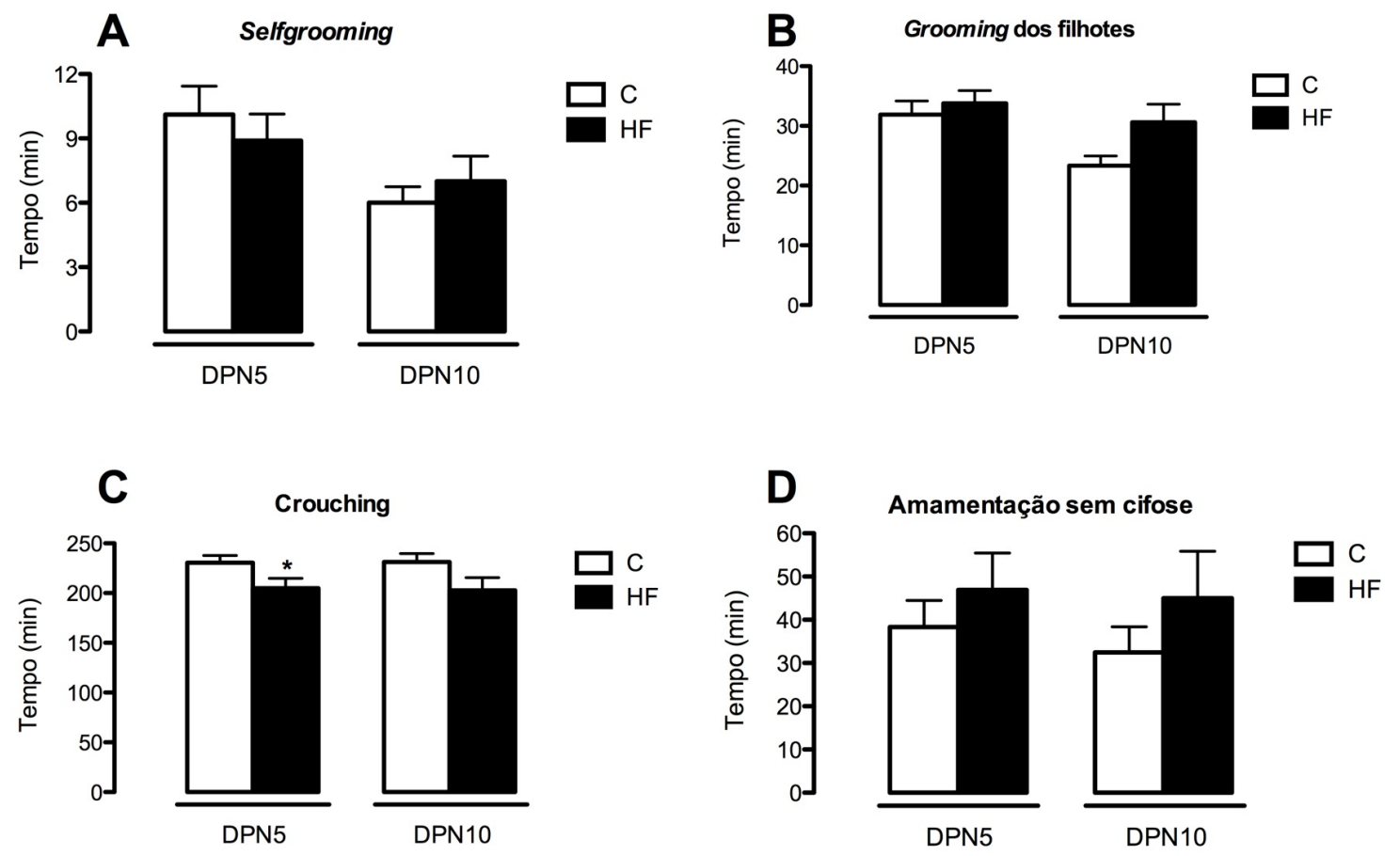

Os dados são expressos em média \pm E.P.M. C (controle): $n=9 ; H F$ (hiperlipídica): $n=10$. A. Selfgrooming, efeito significante de tempo, $p<0,01$. B. Limpeza dos filhotes, efeito significante de tempo, $p<0,05$. C. Tempo amamentando em cifose, efeito de grupo significante, $p<0,05$. ${ }^{*} p<0,05$ comparado ao grupo controle, teste T de Student. D. Tempo amamentando os filhotes sem a posição de cifose. ANOVA de duas vias.

Durante as análises, foi selecionado o maior período em que as mães permaneceram em cifose sobre os filhotes para observação de parâmetros de ejeção de leite (Figura 18). Em ambos os grupos, esse tempo foi de aproximadamente 50 minutos (3000s), não importando o dia da lactação em que se encontravam. A latência para a primeira ejeção de leite também não apresentou diferença entre os grupos, sendo que no DPN10 esse tempo é maior comparado ao DPN5 (efeito de tempo significante, $p=0,0462 ; F(1,17)=4,623$ ). Entretanto, $o$ número de ejeções de leite apresentadas nesse período foi menor nas fêmeas do grupo HF (efeito significante de grupo, $p=0,0051 ; F(1,17)=10,32$ ), sendo que ambos os grupos apresentam menor número de ejeções no DPN10 (efeito significante de tempo, $p=0,0011 ; F(1,17)=15,25)$. Assim, o tempo médio entre uma ejeção e outra mostrou-se maior no DPN10 para os dois grupos (efeito significante de tempo, $p<0,0001 ; F(1,17)=37,14)$, sendo que no grupo HF esse intervalo entre as ejeções foi maior comparado ao grupo controle (efeito significante de grupo, $p=0,0007$; $F(1,17)=17,15)$. 
Figura 18 - Parâmetros da ejeção de leite avaliados nos grupo $\mathrm{C}$ e $\mathrm{HF}\left(\mathrm{F}_{0}\right)$.

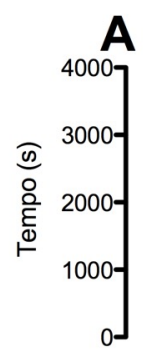

Maior periodo em crouching

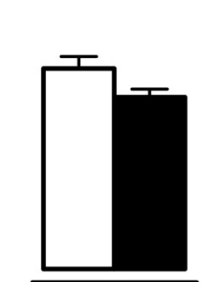

DPN5

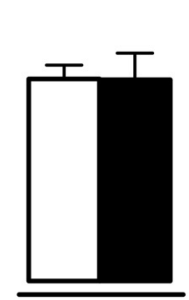

DPN10

C

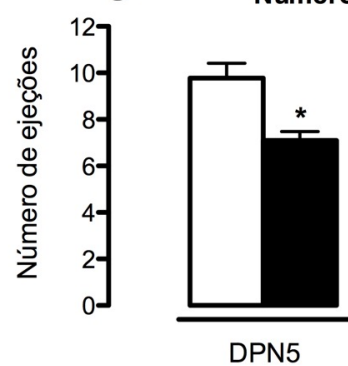

Número de ejeções

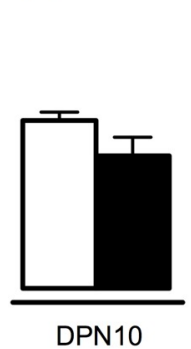

B

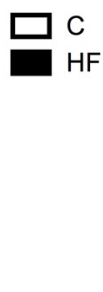

$\left.\begin{array}{cc} & 700 \\ & 600- \\ \frac{0}{0} & 500- \\ \frac{\pi}{0} & 400- \\ \frac{0}{0} & 300- \\ \frac{\Phi}{\omega} & 200- \\ & 100- \\ & 0\end{array}\right]$

D

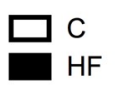

Os dados são expressos em média \pm E.P.M. C (controle): $n=9$; HF (hiperlipídica): $n=10$. ANOVA de duas vias seguida pelo teste de Bonferroni. A. Maior período que a rata mãe ficou na posição de cifose durante as 6 horas avaliadas. B. Latência para a primeira ejeção de leite, efeito significante de tempo, $p<0,05$. C. Número de ejeções apresentadas durante a cifose mais longa, efeito significante de tempo e de grupo, $p<0,01$. D. Intervalo médio entre as ejeções, efeito de tempo e grupo significantes, $p<0,001$. ${ }^{*} p<0,01$ comparado ao grupo controle no mesmo dia pós-natal.

\subsubsection{Análises bioquímicas e hormonais das mães - Geração $F_{0}$}

Os dados das análises bioquímicas realizadas nas mães $F_{0}$ no dia do desmame (DPN 21) são mostrados na Tabela 2.

Não houve diferença estatisticamente significante em nenhum dos parâmetros analisados, porém, o colesterol total apresentou uma tendência à diferença entre os grupos no teste $U$ de Mann-Whitney $(p=0,0788)$.

Foram dosados os hormônios leptina e insulina nas mães no DPN21, não apresentando nenhuma diferença entre os grupos (Figura 19). 
Tabela 2 - Parâmetros bioquímicos das mães (geração F0) no DPN21 - dia do desmame.

\begin{tabular}{ccc}
\hline Parâmetros & \multicolumn{2}{c}{ Grupos } \\
\cline { 2 - 3 } & $C$ & $H F$ \\
\hline Colesterol $(\mathrm{mg} / \mathrm{dL})$ & $67,7 \pm 6,8$ & $49,6 \pm 1,4$ \\
HDL-colesterol $(\mathrm{mg} / \mathrm{dL})$ & $35,2 \pm 3,4$ & $35,6 \pm 2,2$ \\
LDL-colesterol $(\mathrm{mg} / \mathrm{dL})$ & $21,3 \pm 2,8$ & $20,0 \pm 0,5$ \\
Triglicérides $(\mathrm{mg} / \mathrm{dL})$ & $108,7 \pm 10,5$ & $119,5 \pm 8,8$ \\
AST $(\mathrm{U} / \mathrm{L})$ & $227,9 \pm 24,2$ & $257,5 \pm 16,9$ \\
ALT $(\mathrm{U} / \mathrm{L})$ & $33,8 \pm 15,3$ & $15,3 \pm 4,3$ \\
\hline
\end{tabular}

Os dados são expressos em média \pm E.P.M. C (controle): $n=8$; HF (hiperlipídica): $n=8$. Test t de Student. O teste de variância amostral mostrou-se significante para os parâmetros de colesterol, LDL e ALT. Por esse motivo, foi utilizado o teste de U de Mann-Whitney para esses parâmetros. AST: aspartato amino transferase; ALT: alanina amino transferase.

Figura 19 - Níveis de insulina e leptina séricos nas lactantes $F_{0}$.

A

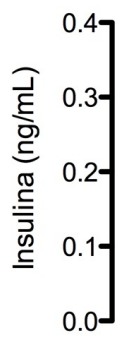

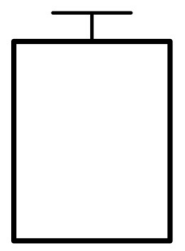

C

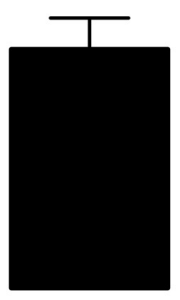

$\mathrm{HF}$

\section{B}

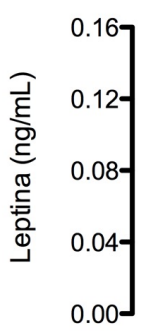

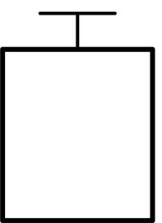

C

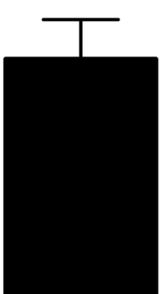

HF

Os dados são apresentados em média \pm E.P.M. C (controle): $n=8 ; \mathrm{HF}$ (hiperlipídica): $\mathrm{n}=8$. Test $\mathrm{t}$ de Student.

\subsubsection{Análises moleculares das mães - Geração $F_{0}$}

Os dados de análise da expressão dos genes Oprm1, Oprk1 e Oprd1 e da expressão protéica de MOR, KOR e DOR no hipotálamo, que codificam os receptores opióides $\mu, \kappa$ e $\delta$ respectivamente, são apresentados na figura 20.

Para os dados de expressão gênica, houve um aumento da expressão dos genes Oprm1, Oprk1 e Oprd1 nas mães do grupo HF aos 21 dias de lactação $(p<0,001$ - Figura 20A, 20B e 20C respectivamente). Em relação à expressão proteica, as proteínas KOR e DOR têm expressão maior nos animais do grupo HF em relação ao controle ( $p<0,001$ - Figuras 20E e 20F respectivamente). 
Figura 20 - Análise da expressão dos genes Oprm1, Oprk1 e Oprd1 e das proteínas MOR, KOR e DOR nas mães da geração $F_{0}$.
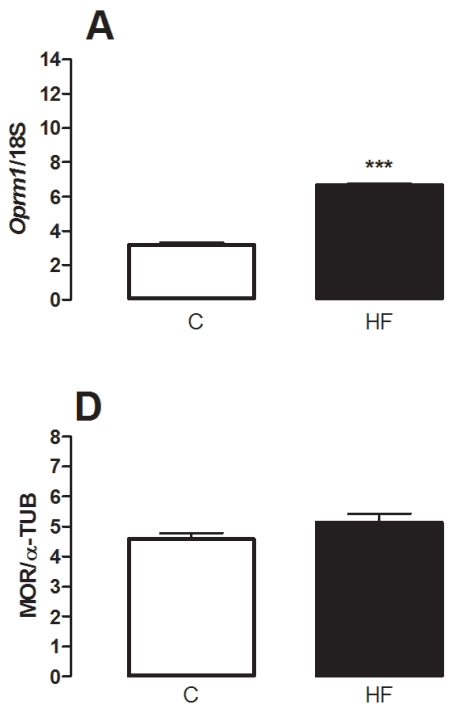

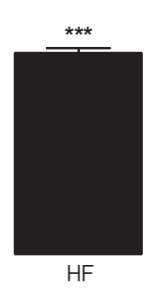

E
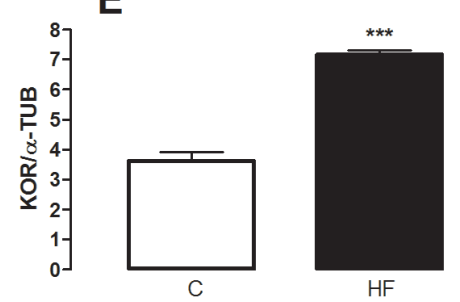
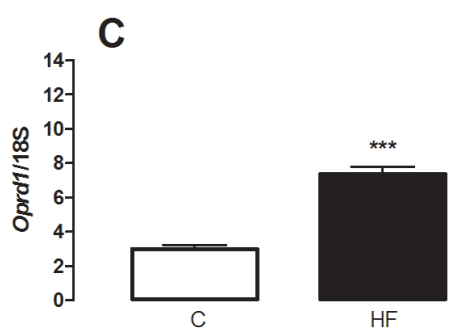

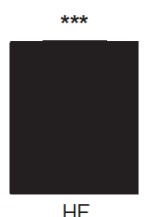

Os dados são expressos em média \pm E.P.M. C (controle): $n=8$; HF (hiperlipídica): $n=8$. A, B e C apresentam os dados dos produtos de expressão gênica Oprm1, Oprk1 e Oprd1, respectivamente, por qPCR de RNA total extraído do hipotálamo dos animais de ambos os grupos $\mathrm{C}$ e HF, em relação ao gene $18 S$ de expressão constitutiva. D, E e F apresentam a imuno-reatividade para as proteínas que codificam os receptores $\mu, \mathrm{k}$ e $\delta$ opióides (Western Blotting). Os dados são expressos como a razão da intensidade densitométrica da banda imuno-reativa para cada um dos receptores opióides divididos pela banda de imuno-reatividade da $\alpha$-tubulina. Test t de Student. ${ }^{* * *} p<0,001$ comparado ao grupo controle.

4.1.4 Peso corporal, peso do fígado e do tecido adiposo no DPN 21 das mães Geração $F_{0}$

Logo após o desmame, no DPN 21, as mães sofreram eutanásia e tiveram o fígado e o tecido adiposo retroperitoneal e retrogonadal pesados para avaliação dos efeitos da dieta sobre esses tecidos. Esses dados, assim como o peso corporal das mães e a glicemia após restrição alimentar são apresentados na tabela 3.

Não houve diferença significante no peso corporal, o peso do fígado e na glicemia das mães HF em relação às do grupo C. As fêmeas do grupo HF apresentaram uma menor quantidade de tecido adiposo retroperitoneal e retrogonadal significantemente menor que aquelas observadas no grupo $C(p<0,05)$. 
Tabela 3 - Peso corporal, dos órgãos, e glicemia de jejum das mães $F_{0}$ após o desmame no DPN21.

\begin{tabular}{ccc}
\hline Parâmetros & \multicolumn{2}{c}{ Grupos } \\
\cline { 2 - 3 } & $C$ & $H F$ \\
\hline Peso corporal $(\mathrm{g})$ & $274,8 \pm 4,6$ & $276,3 \pm 5,6$ \\
Fígado $(\mathrm{g})$ & $13,05 \pm 0,7$ & $13,62 \pm 0,5$ \\
Tec. adiposo & $0,65 \pm 0,07$ & $0,41 \pm 0,07^{*}$ \\
retroperitoneal $(\mathrm{g})$ & $1,65 \pm 0,16$ & $1,03 \pm 0,17^{*}$ \\
Tec. Adiposo gonadal $(\mathrm{g})$ & $81,2 \pm 3,5$ & $90,4 \pm 4,2$ \\
Glicemia (mg/dL) & &
\end{tabular}

Os dados são expressos em média \pm E.P.M. C (controle): $n=9$; HF (hiperlipídica): $n=10$. Test $t$ de Student. ${ }^{*} p<0,05$ comparado ao grupo $C$.

\subsection{Parâmetros de desenvolvimento dos filhotes até o DPN70 - Geração $F_{1}$}

No DPN1, os neonatos foram classificados de acordo com seu peso ao nascimento em adequados, pequenos ou grandes para a idade de prenhez. Não houve diferenças entre os grupo como mostra a figura 21. A maioria dos filhotes foi classificada como apresentando peso adequado.

O ganho de peso da ninhada acompanhado diariamente do DPN 1 ao 21 é mostrado na figura 22. Houve efeito significante do tempo $(p<0,0001 ; F(20,340)=$ 1472) como esperado, e a interação tempo $X$ grupo também apresentou-se significante $(p<0,0001 ; F(20,340)=2,877)$. Isso indica que os grupos responderam diferentemente um do outro ao longo do tempo, porém não houve diferença estatisticamente significante entre os grupos.

Figura 21 - Classificação dos neonatos de acordo com o peso ao nascimento - $F_{1}$.

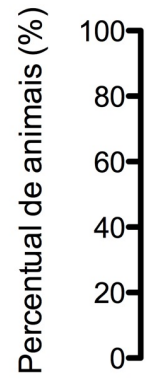

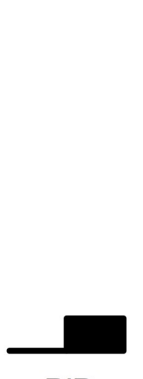

PIP

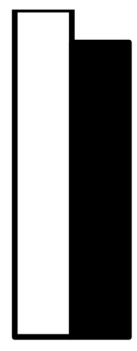

AIP

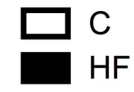

GIP

Os dados são expressos em percentual de animais classificados em cada categoria. $C$ (controle): $n=$ 18; HF (hiperlipídica): $n=20$. PIP: pequeno para idade de prenhez; AIP: adequado para a idade de prenhez; GIP: grande para a idade de prenhez. Teste de Fisher. 
Figura 22 - Peso da ninhada durante a lactação - Geração $F_{1}$.

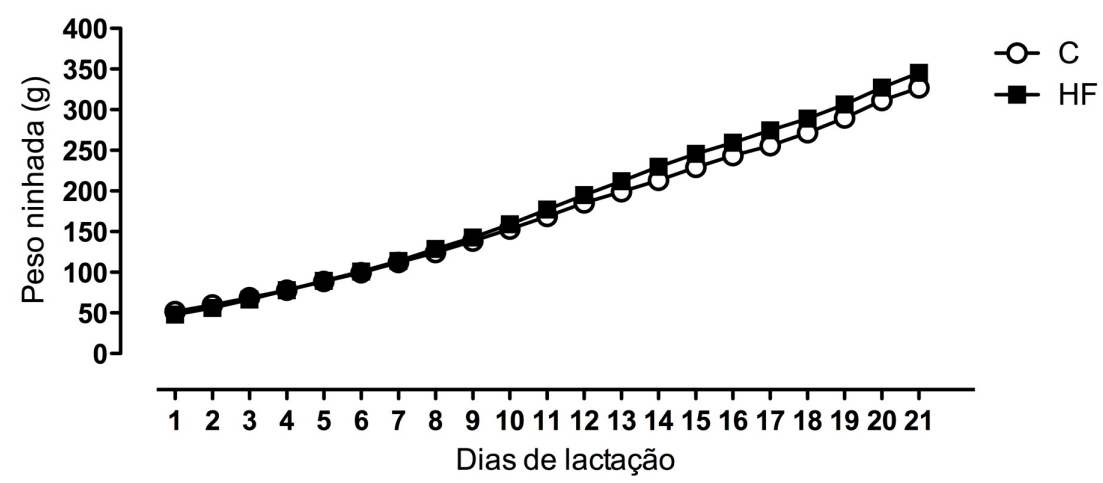

Os dados são expressos em média \pm E.P.M. C (controle): $n=9$; HF (hiperlipídica): $n=10$. ANOVA de duas vias. Efeito significante de tempo, $p<0,0001$. Efeito significante de interação tempo $x$ grupo, $p<0,0001$.

O ganho de peso individual dos filhotes, separados em machos e fêmeas, o comprimento corporal (comprimento naso-anal) no DPN 1, 10 e 21, e a distância ano-genital nos DPN 1 e 21 podem sem observados na tabela 4.

Como esperado, houve efeito significante do tempo para o peso corporal $(p<0,0001 ; F(2,17)=1395$ machos; $p<0,0001 ; F(2,17)=2476$ fêmeas $)$, para o comprimento corporal $(p<0,0001 ; F(2,17)=2279$ machos; $p<0,0001 ; F(2,17)=315,1$ fêmeas) e para a distância ano-genital $(p<0,0001 ; F(1,17)=1525$ machos; $F(1,17)=$ 1966 fêmeas) em ambos os sexos. Nos machos, houve interação tempo x grupo para os parâmetros de peso corporal ( $p=0,0405 ; F(2,17)=3,528$ ) e comprimento corporal $(p=0,0014 ; F(2,17)=8,024)$. Não houve diferença entre os grupos em nenhum dos parâmetros analisados.

A figura 23 mostra os parâmetros de desenvolvimento físico dos filhotes $F_{1}$. Não houve diferenças estatísticas para o dia de descolamento das orelhas, dia de aparecimento dos pelos, erupção dos incisivos e de abertura dos olhos. Nos parâmetros de desenvolvimento sexual mostrados na figura 24 , ambos os grupos tiveram a descida dos testículos ocorrendo aproximadamente no DPN 22 e o descolamento de prepúcio no DPN 43. Também não houve diferença entre os grupos no parâmetro de desenvolvimento sexual feminino, sendo que houve a abertura do canal vaginal aproximadamente no DPN 37. 
Tabela 4 - Peso corporal, comprimento corporal e distância ano-genital dos filhotes machos e fêmeas de cada grupo da geração $F_{1}$.

\section{Grupos}

\begin{tabular}{cccccc}
\multicolumn{2}{c}{ Parâmetros } & \multicolumn{2}{c}{ Machos } & \multicolumn{2}{c}{ Fêmeas } \\
\cline { 3 - 6 } & & C & $H F$ & 6 & $H F$ \\
\hline Peso & DPN1 & $6,6 \pm 0,25$ & $6,2 \pm 0,27$ & $6,3 \pm 0,25$ & $5,9 \pm 0,24$ \\
Individual & DPN10 & $19,1 \pm 0,98$ & $20,4 \pm 1,05$ & $19,2 \pm 0,68$ & $19,5 \pm 0,93$ \\
(g) & DPN21 & $40,6 \pm 1,56$ & $43,8 \pm 1,21$ & $40,8 \pm 0,99$ & $42,3 \pm 1,09$ \\
Comprimento & DPN1 & $5,08 \pm 0,07$ & $4,82 \pm 0,08$ & $4,95 \pm 0,07$ & $4,76 \pm 0,07$ \\
Naso-anal & DPN10 & $7,28 \pm 0,11$ & $7,30 \pm 0,13$ & $7,58 \pm 0,27$ & $7,28 \pm 0,13$ \\
(cm) & DPN21 & $9,92 \pm 0,17$ & $10,27 \pm 0,16$ & $9,59 \pm 0,32$ & $9,99 \pm 0,14$ \\
Distância & DPN1 & $0,37 \pm 0,02$ & $0,34 \pm 0,01$ & $0,19 \pm 0,008$ & $0,18 \pm 0,004$ \\
ano- & & & & & $0,87 \pm 0,021$ \\
genital (cm) & DPN21 & $1,49 \pm 0,05$ & $1,54 \pm 0,04$ & $0,91 \pm 0,020$ \\
\hline
\end{tabular}

Os dados são expressos em média \pm E.P.M. C (controle): $n=9 ; \mathrm{HF}$ (hiperlipídica): $\mathrm{n}=10$. ANOVA de duas vias. $O$ efeito do tempo foi significante para ambos os sexos nos parâmetros de peso corporal, comprimento naso-anal e distância ano-genital $(p<0,0001)$. Efeito significante de interação tempo $x$ grupo para os machos no peso corporal $(p<0,05)$ e no comprimento naso-anal $(p<0,01)$.

Figura 23 - Parâmetros de desenvolvimento físico da geração $F_{1}$.

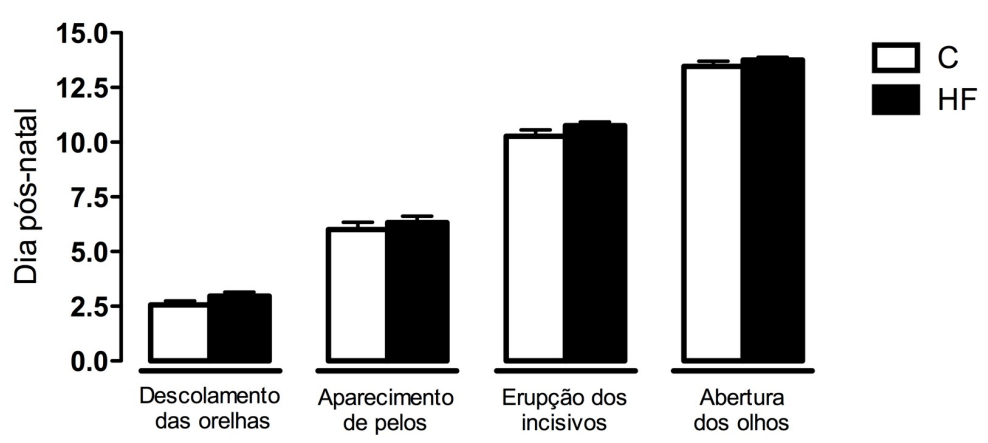

Os dados são expressos em média \pm E.P.M. C (controle): $n=9 ; \mathrm{HF}$ (hiperlipídica): $\mathrm{n}=10$. Teste $\mathrm{t}$ de Student. 
Figura 24 - Parâmetros de desenvolvimento sexual dos animais da geração $F_{1}$.

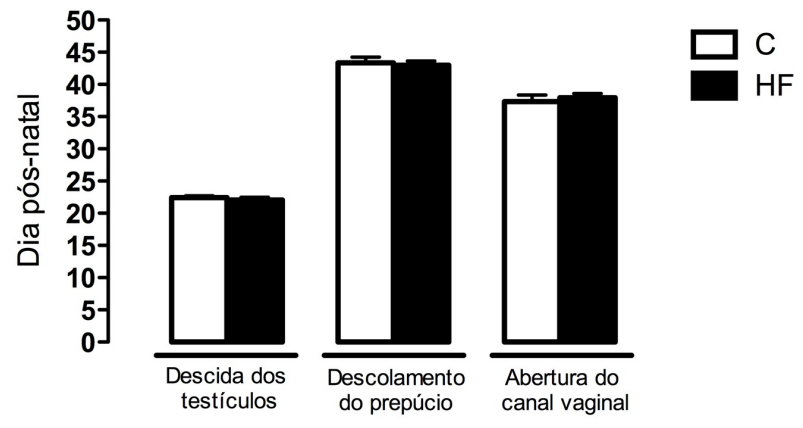

Os dados são expressos em média \pm E.P.M. C (controle): $n=9 ; \mathrm{HF}$ (hiperlipídica): $\mathrm{n}=10$. Teste $\mathrm{t}$ de Student.

Após o desmame, as ninhadas foram subdivididas conforme descrito anteriormente. Portanto, a partir deste ponto, os resultados referem-se à geração $F_{1}$ e seus 4 grupos que a constituem: CC, CHF, HFC e HFHF.

A figura 25 mostra o ganho de peso corporal dos animais até a $12^{\mathrm{a}}$ semana de vida (DPN85). Houve efeito de tempo significante, como esperado, para os machos $(p<0,0001 ; F(8,240)=4279)$ e fêmeas $(p<0,0001 ; F(8,240)=2037)$. Nos machos (figura 25A), os grupos responderam de forma diferente à ingestão das rações ao longo do tempo, demonstrado pela existência da interação grupo $x$ tempo $(p<0,05 ; F(24,240)=1,856)$. Ainda em relação aos machos, houve uma tendência à diferença estatística entre os grupos $(p=0,0915 ; F(3,30)=2,358)$.

Figura 25 - Peso corporal dos machos (A) e fêmeas (B) do DPN 21 ao 85.
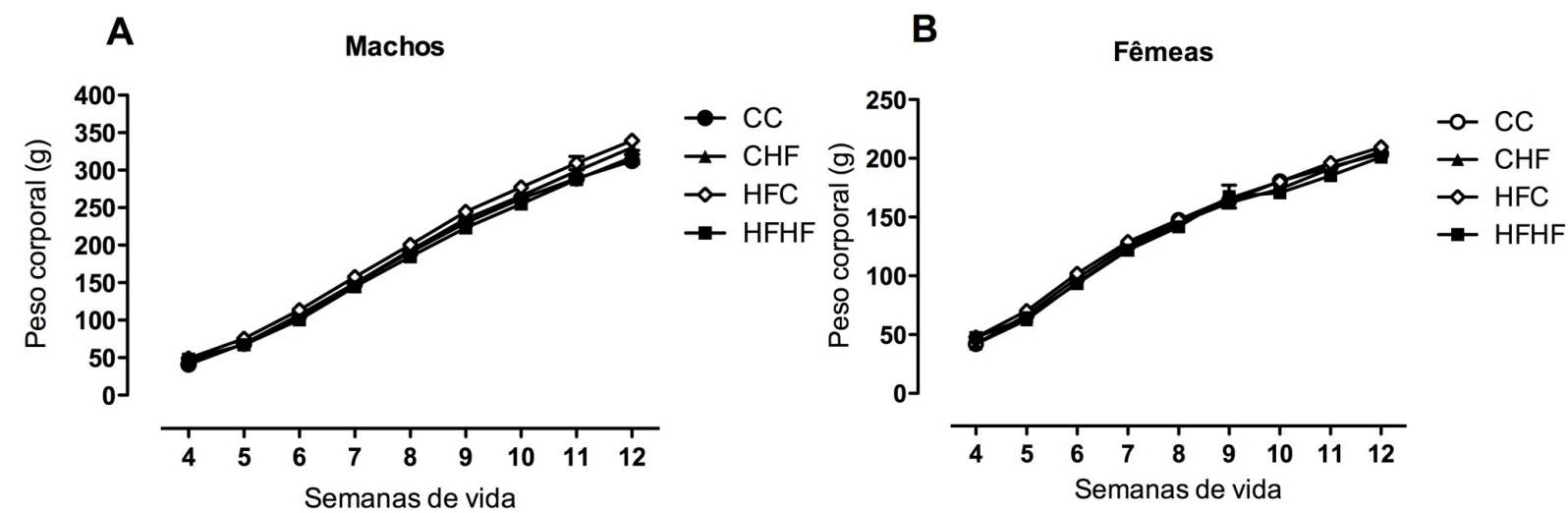

Os dados são expressos em média \pm E.P.M. CC (controle-controle): $\mathrm{n}=8$; CHF (controlehiperlipídica): $\mathrm{n}=8$; HFC (hiperlipídica-controle): $\mathrm{n}=8$; HFHF (hiperlipídica-hiperlipídica): $\mathrm{n}=10$. ANOVA de duas vias. A. Ganho de peso corporal dos machos. Efeito de tempo significante $(p<0,0001)$; efeito de interação tempo x grupo significante $(p<0,05)$. B. Ganho de peso corporal das fêmeas. Efeito de tempo significante $(p<0,0001)$. 
O acompanhamento da ingestão alimentar semanal dos animais do foi realizado do DPN21 ao 70 , ou seja, da $4^{\mathrm{a}}$ à $10^{\mathrm{a}}$ semana de vida pós-natal (Figura 26). A semana de vida em que esses animais se encontravam exerceu efeito sobre o consumo dos mesmos, como esperado (efeito significante de tempo $p>0,0001$; $F(6,180)=308,4$ machos $-p<0,0001 ; F(6,180)=279,7$ fêmeas $)$.

Em relação aos machos, houve efeito significante de grupo para o consumo alimentar $(p<0,0001 ; F(3,30)=18,48)$. Neles (Figura 26A), os grupo CHF e HFHF já apresentaram consumo maior que o grupo HFC, mas não maior que o controle (CC), na $4^{\text {a }}$ semana pós-natal. O grupo HFHF apresentou um consumo calórico significativamente maior que todos os demais grupos na $5^{\mathrm{a}}, 6^{\mathrm{a}}$ e $7^{\mathrm{a}}$ semanas de vida. A ingestão alimentar do grupo $\mathrm{CHF}$ também se mostrou maior que o grupo CC nessas semanas, porém não tão alta quanto o grupo HFHF. A interação grupo $x$ tempo também se mostrou significante na ingestão alimentar semanal dos machos $(p=0,0001 ; F(18,180)=8,507)$.

Figura 26 - Ingestão alimentar semanal dos machos (A) e das fêmeas (B) da semana 4 a 10 de vida.
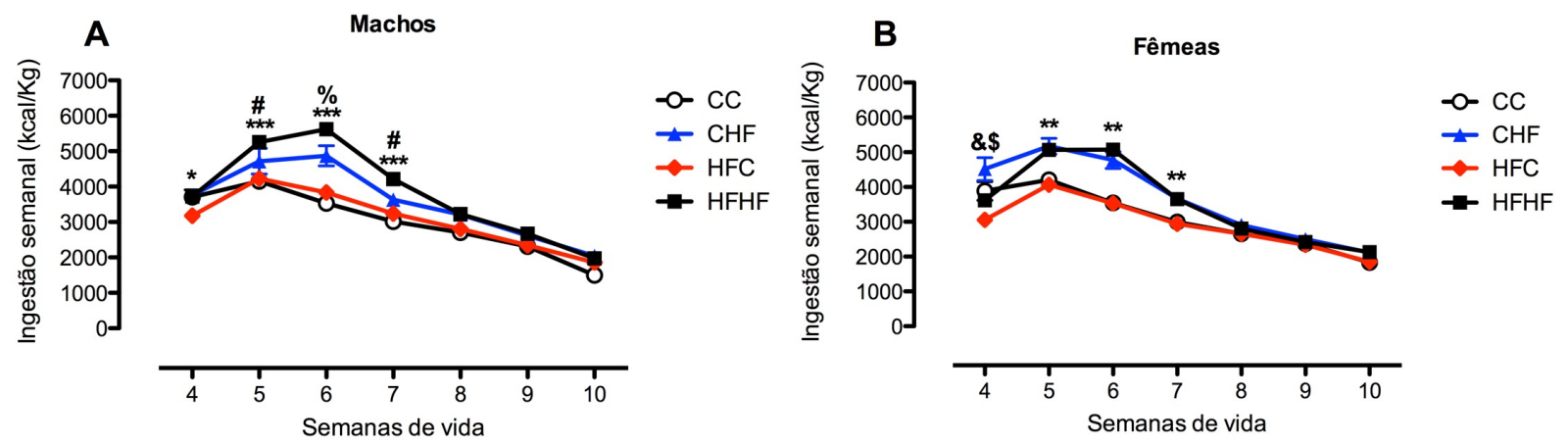

Os dados são expressos em média \pm E.P.M. CC (controle-controle): $n=8$; CHF (controlehiperlipídica): $n=8$; HFC (hiperlipídica-controle): $n=8 ;$ HFHF (hiperlipídica-hiperlipídica): $n=10$. ANOVA de duas vias seguida pelo teste de Bonferroni. A. Ingestão alimentar dos machos. Efeito de tempo significante, $p<0,0001$. Efeito de interação grupo $x$ tempo significante, $p<0,0001$. Efeito de grupo significante, $p<0,0001$. * indica $p<0,05$ para os grupos CHF e HFHF em relação ao grupo HFC; ${ }_{* * *}$ indica $p<0,05$ para o grupo HFHF em relação a todos os demais grupos; \# indica $p<0,05$ para 0 grupo CHF em relação ao CC e HFHF; ${ }^{\%}$ indica $p<0,05$ para o grupo CHF comparando-o a todos os demais grupos. B. Ingestão alimentar das fêmeas. Efeito de tempo significante, $p<0,0001$. Efeito de interação grupo $x$ tempo significante, $p<0,0001$. Efeito de grupo significante, $p<0,0001$. ** indica $p<0,05$ para os grupos CHF e HFHF comparando-os aos grupo controle (CC) e HFC; ${ }^{*}$ indica $p<0,05$ para o CHF em relação aos demais grupos; \$ indica $p>0,05$ para os grupos CC e HFHF comparado ao HFC.

Nas fêmeas (Figura 26B), a ingestão alimentar semanal também mostrou efeito de grupo significante $(p<0,0001 ; F(3,30)=15,11)$. Os grupos CHF e HFHF apresentaram consumo calórico maior que as fêmeas dos grupos CC e HFC, 
principalmente nas semanas 5, 6 e 7. Houve efeito de interação tempo x grupo significante para o consumo semanal das fêmeas $(p<0,0001 ; F(18,180)=9,127)$.

No DPN35, período peripuberal, e no DPN70, vida adulta, um macho e uma fêmea de cada grupo sofreram eutanásia e o peso corporal, do fígado e da gordura retroperitoneal e retrogonadal foram analisados.

A tabela 5 apresenta os dados encontrados nos machos, e mostra que o peso dos animais do grupo HFHF no DPN 35 encontra-se menor que os grupos CC e HFC $(p<0,05 ; F(3,24)=4,560)$. Entretanto, quando os animais atingem os 70 dias de vida, essa diferença não existe mais. Não houve diferença estatisticamente significante em relação aos demais parâmetros.

Tabela 5 - Peso corporal, peso do fígado e dos tecidos adiposos retroperitoneal e retrogonadal de machos aos 35 e 70 dias de vida pós-natal.

\begin{tabular}{|c|c|c|c|c|c|}
\hline \multirow{2}{*}{ Parâmetros } & \multirow{2}{*}{ Machos } & \multicolumn{4}{|c|}{ Grupos } \\
\hline & & $C C$ & $\mathrm{CHF}$ & HFC & HFHF \\
\hline \multirow{2}{*}{$\begin{array}{c}\text { Peso } \\
\text { corporal (g) }\end{array}$} & DPN 35 & $95,7 \pm 5,14$ & $86,9 \pm 2,43$ & $96,1 \pm 4,59$ & $79,2 \pm 2,30^{*}$ \\
\hline & DPN 70 & $276,3 \pm 9,3$ & $259,5 \pm 6,4$ & $276,6 \pm 10,8$ & $260,4 \pm 9,3$ \\
\hline \multirow{2}{*}{ Fígado (g) } & DPN 35 & $3,54 \pm 0,14$ & $3,55 \pm 0,16$ & $3,50 \pm 0,21$ & $3,24 \pm 0,08$ \\
\hline & DPN 70 & $9,19 \pm 0,35$ & $9,06 \pm 0,27$ & $8,67 \pm 0,50$ & $8,66 \pm 0,31$ \\
\hline Tec. adiposo & DPN 35 & $0,15 \pm 0,02$ & $0,16 \pm 0,02$ & $0,12 \pm 0,01$ & $0,16 \pm 0,02$ \\
\hline peritoneal (g) & DPN 70 & $2,44 \pm 0,18$ & $2,76 \pm 0,47$ & $1,79 \pm 0,28$ & $1,73 \pm 0,29$ \\
\hline Tec. adiposo & DPN 35 & $0,35 \pm 0,03$ & $0,32 \pm 0,02$ & $0,30 \pm 0,02$ & $0,27 \pm 0,02$ \\
\hline gonadal (g) & DPN 70 & $2,91 \pm 0,16$ & $2,78 \pm 0,27$ & $2,67 \pm 0,24$ & $2,49 \pm 0,26$ \\
\hline
\end{tabular}

Os dados são expressos em média \pm E.P.M. CC (controle-controle): $n=7$; CHF (controlehiperlipídica): $\mathrm{n}=7$; HFC (hiperlipídica-controle): $\mathrm{n}=7$; HFHF (hiperlipídica-hiperlipídica): $\mathrm{n}=7$. ANOVA de uma via seguida pelo teste de Tukey. ${ }^{*} p<0,05$ em relação aos grupos CC e HFC.

Nas fêmeas, o peso dos animais que receberam dieta hiperlipídica desde a sua concepção (grupo HFHF) apresentou-se significantemente reduzido em relação aos demais grupos no DPN 35 ( $p<0,0001 ; F(3,24)=16,25)$. O grupo CHF também apresentou peso menor em relação ao grupo CC neste dia. Esses dados podem ser observados na tabela 6. Essa diferença não se revelou estatisticamente significante aos 70 dias de vida, apesar de haver uma tendência para diferença entre os grupos $(p=0,062 ; F(3,24)=2,794)$. Em relação ao peso do fígado, nos animais do grupo 
HFHF, este órgão pesava menos do que nos animais do grupo CC no DPN 35 ( $p=$ $0,0179, F(3,24)=4,075)$. Essa diferença não se manteve até a vida adulta $(p>0,05)$.

Tabela 6 - Peso corporal, peso do fígado e dos tecidos adiposos retroperitoneal e retrogonadal em fêmeas no DPN 35 e 70.

\begin{tabular}{|c|c|c|c|c|c|}
\hline \multirow{2}{*}{ Parâmetros } & \multirow{2}{*}{ Fêmeas } & \multicolumn{4}{|c|}{ Grupos } \\
\hline & & $C C$ & $\mathrm{CHF}$ & HFC & HFHF \\
\hline Peso & DPN 35 & $100,4 \pm 2,78$ & $85,4 \pm 2,22^{*}$ & $92,5 \pm 3,65$ & $74,2 \pm 2,15^{\star *}$ \\
\hline corporal (g) & DPN 70 & $189,9 \pm 3,31$ & $175,9 \pm 4,52$ & $187,1 \pm 2,19$ & $180,3 \pm 4,71$ \\
\hline \multirow{2}{*}{ Fígado (g) } & DPN 35 & $3,5 \pm 0,10$ & $3,2 \pm 0,08$ & $3,2 \pm 0,14$ & $3,0 \pm 0,10^{*}$ \\
\hline & DPN 70 & $6,27 \pm 0,22$ & $6,25 \pm 0,29$ & $6,12 \pm 0,17$ & $6,75 \pm 0,33$ \\
\hline Tec. adiposo & DPN 35 & $0,20 \pm 0,06$ & $0,15 \pm 0,02$ & $0,13 \pm 0,01$ & $0,12 \pm 0,02$ \\
\hline peritoneal (g) & DPN 70 & $1,06 \pm 0,03$ & $0,81 \pm 0,14$ & $1,10 \pm 0,18$ & $1,05 \pm 0,31$ \\
\hline Tec. adiposo & DPN 35 & $0,25 \pm 0,03$ & $0,21 \pm 0,03$ & $0,22 \pm 0,02$ & $0,19 \pm 0,05$ \\
\hline gonadal (g) & DPN 70 & $1,87 \pm 0,09$ & $1,65 \pm 0,14$ & $1,93 \pm 0,34$ & $2,00 \pm 0,64$ \\
\hline
\end{tabular}

Os dados são expressos em média \pm E.P.M. CC (controle-controle): $n=7$; CHF (controlehiperlipídica): $\mathrm{n}=7$; HFC (hiperlipídica-controle): $\mathrm{n}=7$; HFHF (hiperlipídica-hiperlipídica): $\mathrm{n}=7$. ANOVA de uma via seguida pelo teste de Tukey. ${ }^{* *} p<0,01$ em relação aos grupos $\mathrm{CC}, \mathrm{HFC}$ e CHF. ${ }^{*} \mathrm{p}<0,05$ em relação ao grupo $\mathrm{CC}$.

Em relação a parâmetros bioquímicos, os machos no DPN 70 apresentaram níveis de AST reduzidos nos animais dos grupos CHF e HFHF comparados ao grupo controle $(p=0,028$. $F(3,25)=3,603)$. As dosagens de colesterol total, HDLcolesterol, LDL-colesterol, triglicérides e ALT não apresentaram diferenças estatisticamente significantes nos dois períodos de vida analisados dos animais (Tabela 7). 
Tabela 7 - Parâmetros bioquímicos dos machos aos 35 e 70 dias de vida pós-natal.

\begin{tabular}{cccccc}
\hline \multirow{2}{*}{ Parâmetros } & Machos & \multicolumn{4}{c}{ Grupos } \\
& & CC & CHF & $H F C$ & HFHF \\
\hline Colesterol & DPN35 & $53,9 \pm 0,6$ & $64,5 \pm 4,6$ & $58,6 \pm 3,2$ & $61,4 \pm 5,0$ \\
(mg/dL) & DPN70 & $83,3 \pm 1,9$ & $93,5 \pm 5,1$ & $88,3 \pm 4,4$ & $93,6 \pm 3,7$ \\
HDL- & DPN35 & $24,0 \pm 1,5$ & $29,1 \pm 1,8$ & $23,6 \pm 1,4$ & $28,8 \pm 4,0$ \\
colesterol & & & & & \\
(mg/dL) & DPN70 & $28,8 \pm 3,6$ & $35,5 \pm 3,5$ & $28,2 \pm 4,6$ & $33,6 \pm 3,2$ \\
LDL-colesterol & DPN35 & $21,0 \pm 2,7$ & $28,3 \pm 2,6$ & $25,9 \pm 4,2$ & $28,2 \pm 6,8$ \\
(mg/dL) & DPN70 & $45,4 \pm 4,7$ & $49,2 \pm 6,8$ & $52,0 \pm 4,2$ & $50,3 \pm 5,3$ \\
Triglicérides & DPN35 & $151,1 \pm 11,8$ & $143,2 \pm 14,2$ & $156,6 \pm 8,9$ & $160,1 \pm 13,2$ \\
(mg/dL) & DPN70 & $95,3 \pm 6,3$ & $94,4 \pm 8,7$ & $91,9 \pm 5,1$ & $97,3 \pm 3,9$ \\
AST (U/L) & DPN35 & $244,2 \pm 22,1$ & $270,1 \pm 18,4$ & $230,0 \pm 13,0$ & $242,2 \pm 20,7$ \\
& DPN70 & $199,4 \pm 12,8$ & $137,6 \pm 16,7^{*}$ & $156,2 \pm 15,6$ & $140,6 \pm 14,6^{*}$ \\
ALT (U/L) & DPN35 & $248,2 \pm 53,3$ & $161,6 \pm 45,5$ & $264,3 \pm 54,4$ & $119,7 \pm 64,8$ \\
& DPN70 & $57,7 \pm 5,9$ & $49,0 \pm 7,3$ & $58,8 \pm 7,1$ & $53,0 \pm 8,6$ \\
\hline
\end{tabular}

Os dados são expressos em média \pm E.P.M. CC (controle-controle): $n=7$; CHF (controlehiperlipídica): $\mathrm{n}=7$; HFC (hiperlipídica-controle): $\mathrm{n}=7$; HFHF (hiperlipídica-hiperlipídica): $\mathrm{n}=7$. ANOVA de uma via seguida pelo teste de Tukey. ${ }^{*} p<0,05$ em relação ao grupo CC.

As fêmeas não apresentaram diferenças estatísticas nos parâmetros bioquímicos analisados em nenhum dos períodos (DPN 35 e 70), como mostra a tabela 8.

Nos animais adultos (DPN 70), também foram realizadas as dosagens dos hormônios leptina e insulina como mostra a figura 27. Nos machos, não houve diferenças estaticamente significante entre os grupos para os hormônios avaliados $(p>0,05)$. Entretanto, há uma tendência à diferença entre os grupos na dosagem de insulina $(p=0.0891 ; F(3,16)=2,619)$. 
Tabela 8 - Parâmetros bioquímicos das descendentes fêmeas aos 35 e 70 DPN.

\begin{tabular}{cccccc}
\hline \multirow{2}{*}{ Parâmetros } & \multirow{2}{*}{ Fêmeas } & \multicolumn{4}{c}{ Grupos } \\
& & CC & CHF & $H F C$ & HFHF \\
\hline Colesterol & DPN35 & $62,0 \pm 4,5$ & $59,5 \pm 3,5$ & $65,9 \pm 4,1$ & $61,6 \pm 3,9$ \\
(mg/dL) & DPN70 & $97,9 \pm 4,0$ & $87,1 \pm 4,9$ & $101,0 \pm 4,4$ & $88,4 \pm 5,6$ \\
HDL- & DPN35 & $22,2 \pm 1,2$ & $25,9 \pm 1,3$ & $21,7 \pm 1,0$ & $21,9 \pm 1,0$ \\
colesterol & & & & & \\
(mg/dL) & DPN70 & $32,9 \pm 4,6$ & $27,9 \pm 3,2$ & $26,5 \pm 3,8$ & $26,7 \pm 5,3$ \\
LDL-colesterol & DPN35 & $20,8 \pm 2,7$ & $20,4 \pm 3,3$ & $25,1 \pm 2,2$ & $23,9 \pm 2,5$ \\
(mg/dL) & DPN70 & $56,2 \pm 5,7$ & $51,3 \pm 7,2$ & $65,6 \pm 6,6$ & $54,7 \pm 7,2$ \\
Triglicérides & DPN35 & $130,6 \pm 13,6$ & $124,9 \pm 9,4$ & $155,1 \pm 17,5$ & $136,1 \pm 13,8$ \\
(mg/dL) & DPN70 & $94,3 \pm 3,2$ & $91,5 \pm 7,0$ & $94,7 \pm 2,1$ & $88,5 \pm 3,2$ \\
AST (U/L) & DPN35 & $244,2 \pm 22,1$ & $270,1 \pm 18,4$ & $230,0 \pm 13,0$ & $242,2 \pm 20,7$ \\
& DPN70 & $181,2 \pm 31,8$ & $159,1 \pm 25,8$ & $164,2 \pm 19,1$ & $144,4 \pm 32,8$ \\
ALT (U/L) & DPN35 & $229,5 \pm 68,1$ & $325,0 \pm 27,1$ & $262,5 \pm 63,6$ & $171,4 \pm 48,6$ \\
& DPN70 & $59,6 \pm 8,3$ & $47,4 \pm 12,5$ & $36,1 \pm 6,9$ & $57,2 \pm 5,7$ \\
\hline
\end{tabular}

Os dados são expressos em média \pm E.P.M. CC (controle-controle): $\mathrm{n}=7$; CHF (controlehiperlipídica): $n=7$; HFC (hiperlipídica-controle): $n=7$; HFHF (hiperlipídica-hiperlipídica): $n=7$. ANOVA de uma via.

Em relação às fêmeas, o hormônio insulina apresentou maior nível sérico nos grupos HFC e HFHF quando comparados aos grupos CC e CHF $(p=0,0019 ; F(3,12)$ = 9,210 - Figura 27C). Já a leptina no grupo HFHF mostrou-se reduzida quando comparada aos valores encontrados nos grupo CC e HFC $(p=0,0068 ; F(3,12)=$ 6,654 - Figura 27D). 
Figura 27 - Dosagens séricas de insulina e leptina em machos e fêmeas adultos.

A

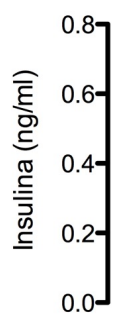

C

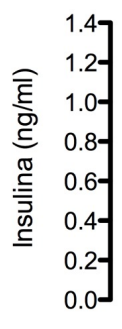

Machos

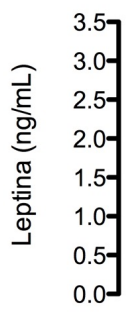

HFHF

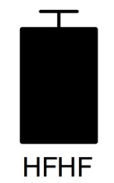

Fêmeas
B

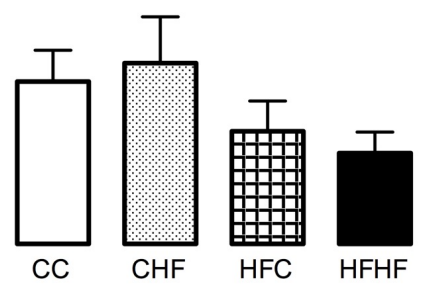

D

Os dados são expressos em média \pm E.P.M. CC (controle-controle): $n=5-4$; CHF (controlehiperlipídica): $n=5-4$; HFC (hiperlipídica-controle): $n=5-4$; HFHF (hiperlipídica-hiperlipídica): $n=5-4$. ANOVA de uma via seguida pelo teste de Tukey. A. Dosagem sérica de insulina nos machos. B. Dosagem sérica de leptina nos machos. C. Dosagem sérica de insulina nas fêmeas no DPN70. ${ }^{*} p<0,05$ comparado aos grupos CC e CHF. D. Dosagem sérica de leptina nas fêmeas. ${ }^{* *} p<0,05$ comparado aos grupos CC e HFC.

\subsubsection{Testes de preferência alimentar e à sacarose}

A fim de avaliar se a alta carga de lipídeos alterou a preferência dos animais quanto ao tipo de dieta ingerida na vida adulta, foi realizado o teste de preferencia alimentar (Figura 28).

Nos machos do grupo controle, a preferência pela ração com alto teor de gordura chegou a $87,64 \%$. Valor próximo ao do encontrado no grupo HFC, que foi de $89,73 \%$. Porém, nos animais que já faziam ingestão da dieta hiperlipídica desde o desmame (grupos CHF e HFHF), esse percentual ficou em 17,81 e 12,25 respectivamente, mostrando uma diferença estatisticamente significante entre os grupos $(p<0,0001 ; K=27,77)$.

O mesmo aconteceu com as fêmeas, onde os grupos CHF e HFHF preferiram $29,65 \%$ e $29,21 \%$, respectivamente, de sua alimentação oriunda da dieta rica em lipídeos, mostrando uma diferença estatística entre os grupos ( $p<0,0001 ; \mathrm{K}=27,64)$. Nas fêmeas do grupo CC essa média foi de $93,75 \%$ e no HFC $95,42 \%$. 
Entre os machos, um grande número de animais que estava sob dieta rica em lipídeos optou exclusivamente por dieta padrão durante o teste $(55,56 \%$ para CHF e $60 \%$ para HFHF). Entre as fêmeas dos mesmo grupos, isso não ocorreu, sendo que apenas $11,1 \%$ das ratas $\mathrm{CHF}$ e $10 \%$ das ratas $\mathrm{HFHF} \%$ não comeram a ração a que estavam habituadas anteriormente $(p=0,0374 ; F(1,2)=289,6$, efeito de sexo significante - ANOVA de duas vias).

Figura 28 - Teste de preferência à dieta hiperlipídica.

A
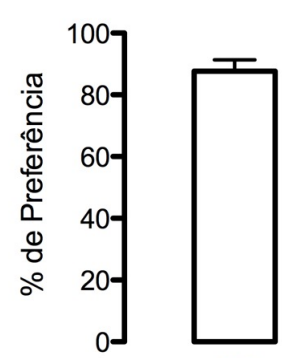

CC
Machos

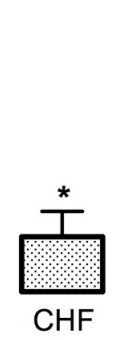

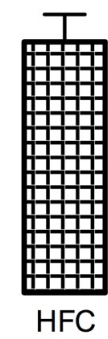

HFC

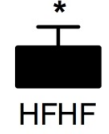

B

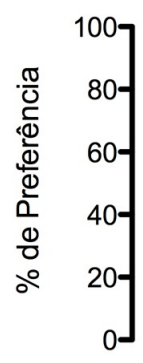

Fêmeas
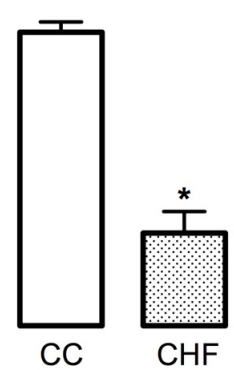
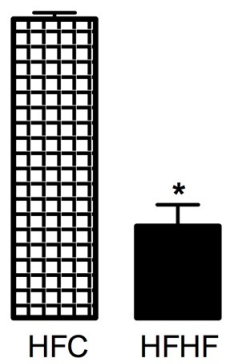

Os dados são expressos em média \pm E.P.M. CC (controle-controle): $n=9$; CHF (controlehiperlipídica): $\mathrm{n}=9$; HFC (hiperlipídica-controle): $\mathrm{n}=10$; HFHF (hiperlipídica-hiperlipídica): $\mathrm{n}=10$. Teste de Kruskal-Wallis seguido pelo teste de Dunn. A. Preferência dos machos à ração rica em lipídeos. B. Preferência das fêmeas quanto à dieta hiperlipídica. ${ }^{*} p<0,05$ comparados aos grupos CC e HFC.

Figura 29 - Teste de preferencia à sacarose.

A

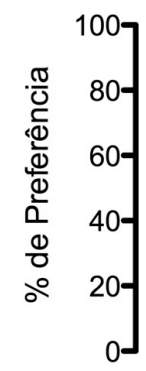

Machos
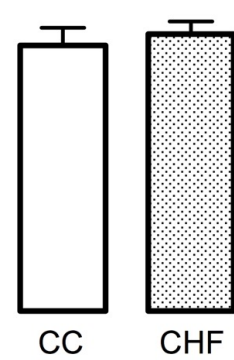
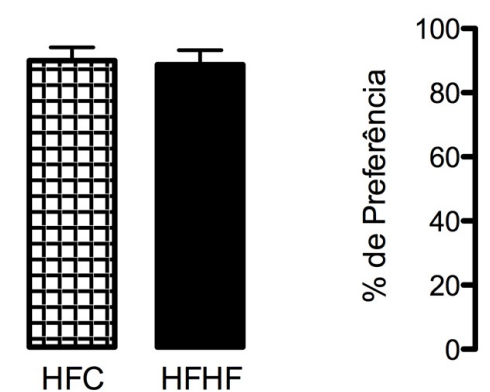

B

Fêmeas

Os dados são expressos em média \pm E.P.M. CC (controle-controle): $\mathrm{n}=9$; CHF (controlehiperlipídica): $n=9$; HFC (hiperlipídica-controle): $n=10$; HFHF (hiperlipídica-hiperlipídica): $n=10$. Teste de Kruskal-Wallis. A. Preferência dos machos à sacarose. B. Preferência à sacarosa das fêmeas.

Também foi realizado o teste de preferencia à sacarose, cujo resultados podem ser observados na figura 29.

Não houve diferenças significantes entre os grupos $(p>0,05)$, sendo que quando lhes é dada a oportunidade de escolha entre água e uma solução contendo 
sacarose, os animais de todos os grupos, em ambos os sexos, preferem $80 \%$ ou mais da sua ingestão de líquidos diária oriunda da sacarose.

\subsection{Mães geração $F_{1}$}

Os dados a seguir apresentados são relacionados somente às fêmeas da geração $F_{1}$. Antes do acasalamento, foi realizado o acompanhamento da duração do ciclo estral desses animais, como mostra a tabela 9. Não houve diferenças significantes entre os grupos, sendo que a duração entre um estro e outro era de aproximadamente 4 dias para todos eles.

Tabela 9 - Duração do ciclo estral.

\begin{tabular}{|c|c|}
\hline Grupo & Duração do ciclo \\
\hline $\mathrm{CC}$ & $4(4-4)$ \\
\hline $\mathrm{CHF}$ & $4(2,75-7)$ \\
\hline HFC & $4(4-6)$ \\
\hline HFHF & $4(3,67-6)$ \\
\hline \multicolumn{2}{|c|}{$\begin{array}{l}\text { Os dados são expressos em mediana (variação } \\
\text { máxima - variação mínima). CC (controle- } \\
\text { controle): } n=9 ; \text { CHF (controle-hiperlipídica): } n= \\
9 ; \text { HFC (hiperlipídica-controle): } n=10 ; \text { HFHF } \\
\text { (hiperlipídica-hiperlipídica): } n=10 \text {. Teste de } \\
\text { Kruskal-Wallis. }\end{array}$} \\
\hline
\end{tabular}

Aos 85 dias de vida, as fêmeas da geração $F_{1}$ foram colocadas na presença machos sexualmente experientes para obtenção da geração $F_{2}$, e realização das análises maternas com as mães da geração $F_{1}$.

No início da gestação, as fêmeas de todos os grupos tinham peso semelhante, como mostra a figura 30. Entretanto, as diferenças de ganho de peso começaram a surgir a partir do DG 13, apresentando efeito de grupo significante ( $p=$ 0,0017; $F(3,30)=120,1)$. O grupo HFHF teve um ganho de peso reduzido quando comparado aos grupos CC e HFC $(p<0,05)$. O mesmo ocorreu com o grupo CHF a partir do $18^{\circ}$ dia de gestação. Houve também efeito da interação tempo x grupo $(p<0,0001 ; F(63,630)=8,636)$. De acordo com o esperado, houve efeito de tempo siginificante $(p<0,0001 ; F(21,630)=1144)$. 
Figura 30 - Peso corporal durante a gestação das mães da geração $F_{1}$.

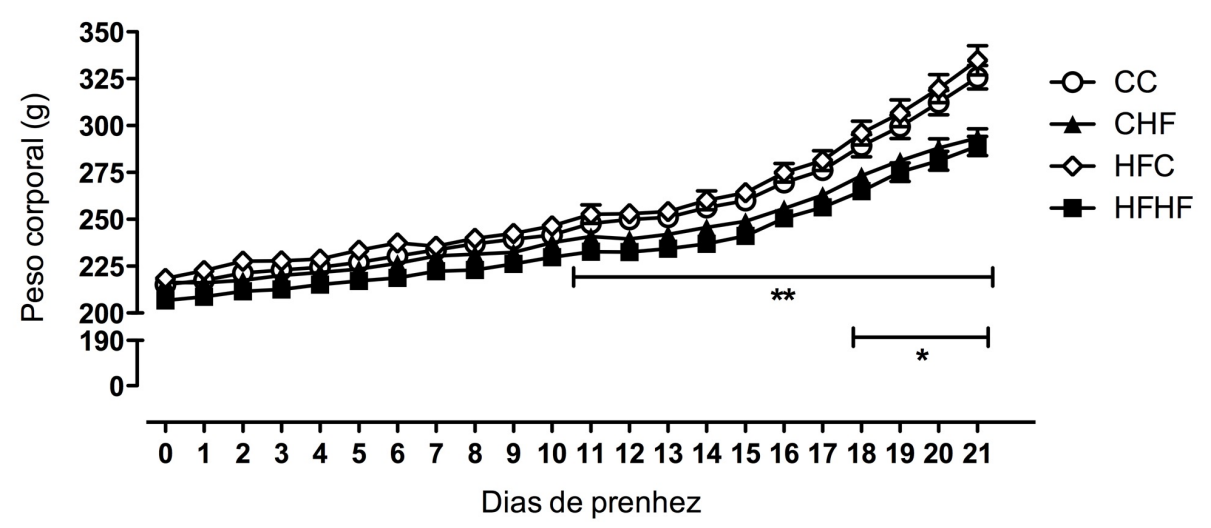

Os dados são expressos em média \pm E.P.M. CC (controle-controle): $\mathrm{n}=8$; CHF (controlehiperlipídica): $n=8$; HFC (hiperlipídica-controle): $n=8 ; \operatorname{HFHF}$ (hiperlipídica-hiperlipídica): $n=10$. ANOVA de duas vias seguida pelo teste de Bonferroni. Efeito de tempo significante, $p<0,0001$. Efeito de interação tempo x grupo significante, $p<0,0001$. Efeito de grupo significante, $p<0,01$. ${ }^{* *}$ indica p<0,05 para o grupo HFHF em relação ao grupo CC do DG 14 a 21, e em relação ao grupo HFC do DG 11 ao 21. * indica $p<0,05$ para o grupo CHF em relação ao grupo CC nos DG 20 e 21 , e em relação ao grupo HFC nos DG 16, 18 a 21.

Figura 31 - Ingestão alimentar durante a gestação das mães $F_{1}$.

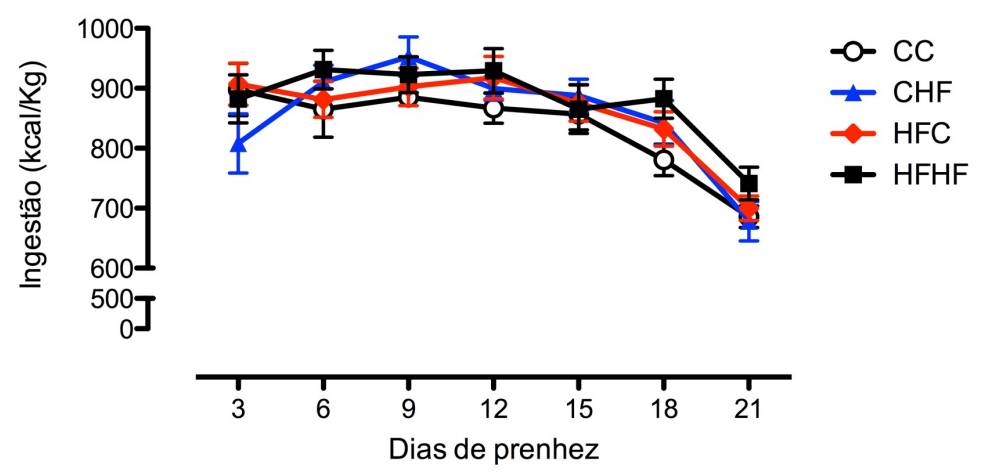

Os dados são expressos em média \pm E.P.M. CC (controle-controle): $\mathrm{n}=8$; CHF (controlehiperlipídica): $\mathrm{n}=8$; HFC (hiperlipídica-controle): $\mathrm{n}=8$; HFHF (hiperlipídica-hiperlipídica): $\mathrm{n}=10$ ANOVA de duas vias. Efeito de tempo significante, $p<0,0001$.

Em relação à quantidade de calorias ingeridas durante a gestação (Figura 31 ), o consumo de cada grupo não diferiu entre si, mas houve efeito de tempo significante, conforme esperado $(p<0,0001 ; F(6,180)=33,19)$.

A glicemia das fêmeas nos DG 0, 7, 14 e 21 sofreu efeito significante do tempo $(p<0,0001 ; F(3,90)=128,0)$ e apresentou um efeito significante da interação tempo $\times$ grupo $(p<0,05 ; F(9,90)=2,194)$. Não houve diferença estatisticamente significante em relação a cada um dos grupos (Figura 32).

No teste de tolerância à insulina (TTI), realizado no DG 15 (Figura 33A), todos os grupos responderam normalmente a injeção de insulina, sendo o efeito de tempo 
significante $(p<0,0001 ; F(5,150)=5,985)$. As fêmeas prenhes de todos os grupos retornaram aos níveis glicêmicos iniciais no tempo final do teste $(p>0,05)$. Em relação ao teste de tolerância oral à glicose (TTOG), todas as ratas responderam elevando os níveis de glicose no sangue e restabelecendo os níveis basais ao final do teste $(p<0,0001 ; F(5,150)=40,36$ - Figura 33B), não havendo diferença entre os grupos. Houve, entretanto, interação do efeito grupo $x$ tempo significante $(p<0,0001$; $F(5,150)=40,36)$. A área sob a curva do TTOG (Figura 33C) apresentou uma tendência à diferença entre os grupos $(p=0,093 ; F(3,30)=2,342)$, indicando que eles podem lidar de forma diferente entre si com a glicose administrada.

Figura 32 - Glicemia nos dias 0, 7, 14 e 21 de gestação das mães da geração $F_{1}$.

Glicemia durante a prenhez

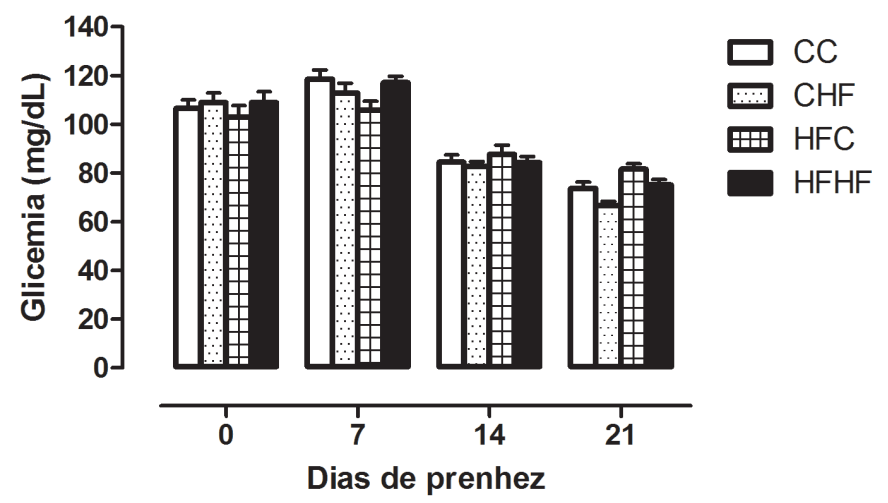

Dados expressos em média \pm E.P.M. CC (controle-controle): $n=8$; CHF (controle-hiperlipídica): $n=8$; HFC (hiperlipídica-controle): $\mathrm{n}=8$; HFHF (hiperlipídica-hiperlipídica): $\mathrm{n}=10$ ANOVA de duas vias. Efeito de tempo significante, $p<0,0001$. Efeito de interação tempo $x$ grupo significante, $p<0,05$.

Durante a lactação, as diferenças de ganho de peso que já haviam se mostrado durante a prenhez, tornaram-se ainda mais evidentes com o efeito de grupo significante $(p<0,0001 ; F(3,30)=24,52)$. O grupo HFHF manteve-se com peso menor que os grupos CC e HFC durante todo o período $(p<0,05)$. O mesmo aconteceu com o grupo CHF, que apenas nos dias 2, 6 e 7 de lactação não apresentou diferenças em relação ao grupo CC (Figura 34). Houve efeito de interação tempo x grupo $(p<0,0001 ; F(60,600)=5,765)$, e como esperado, as fêmeas ganharam peso ao longo do tempo $(p<0,0001 ; F(20,600)=140,5)$. 
Figura 33 - Teste de tolerância à insulina (TTI), teste de tolerância à glicose oral (TTOG), e área sob a curva do TTOG das fêmeas $F_{1}$ prenhes.
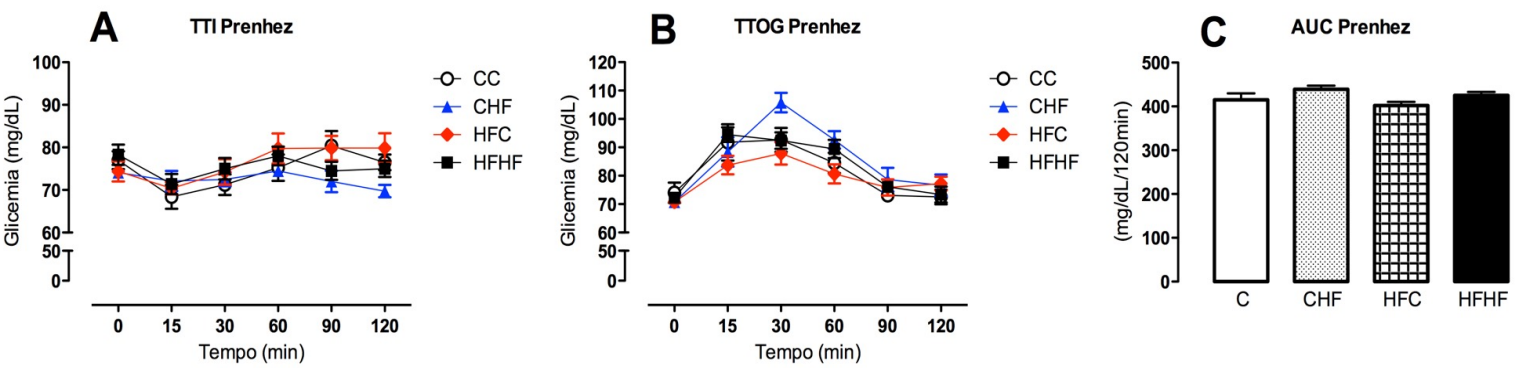

Os dados são expressos em média \pm E.P.M. CC (controle-controle): $n=8$; CHF (controlehiperlipídica): $\mathrm{n}=8$; HFC (hiperlipídica-controle): $\mathrm{n}=8$; HFHF (hiperlipídica-hiperlipídica): $\mathrm{n}=10$. A. TTI realizado no DG 15. ANOVA de duas vias. Efeito de tempo significante, $p<0,0001$. B. TTOG realizado no DG 18. ANOVA de duas vias. Efeito de tempo significante, $p<0,0001$. Efeito de interação tempo $x$ grupo significante, $p<0,05 \mathrm{C}$. Área sob a curva do TTOG. ANOVA de uma via.

Figura 34 - Ganho de peso corporal das fêmeas lactantes da geração $F_{1}$.

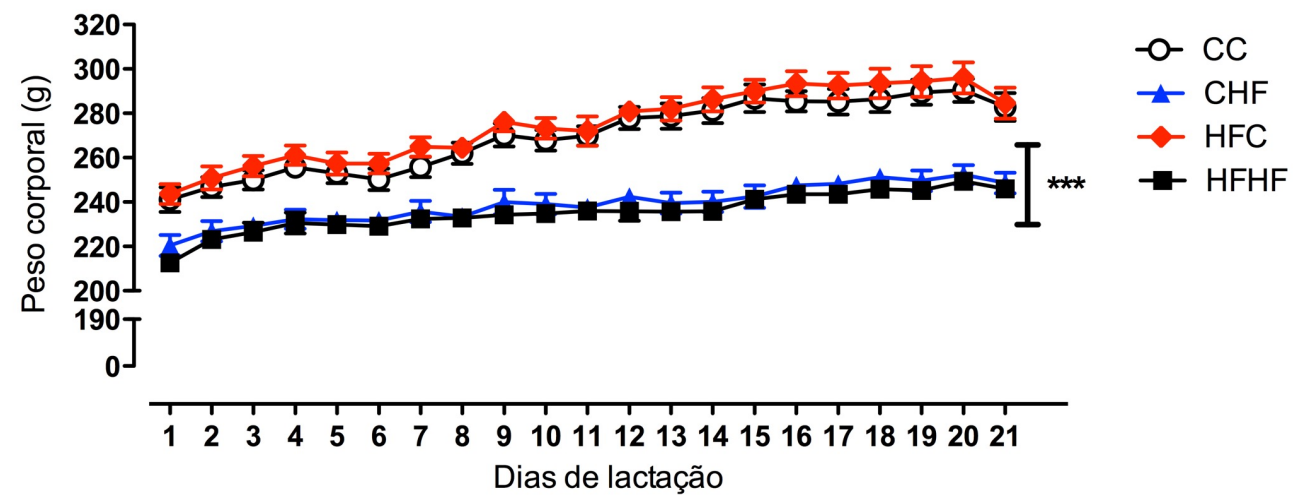

Os dados são expressos em média \pm E.P.M. CC (controle-controle): $n=8$; CHF (controlehiperlipídica): $\mathrm{n}=8$; HFC (hiperlipídica-controle): $\mathrm{n}=8$; HFHF (hiperlipídica-hiperlipídica): $\mathrm{n}=10$. ANOVA de duas vias com pós-teste de Bonferroni. Efeito de tempo significante, $p<0,0001$. Efeito de interação tempo x grupo significante, $p<0,0001$. Efeito de grupo significante, $p<0,0001$. ${ }^{* * *}$ indica $p<0,01$ para os grupos CHF e HFHF em relação aos grupos CC e HFC.

Mesmo apresentando diferenças de peso corporal ao longo da lactação, a ingestão alimentar das fêmeas não apresentou diferenças estatisticamente significantes entre os grupos no mesmo período. Houve efeito do tempo significante $(p<0,0001 ; F(14,420)=161,9)$, uma vez que as lactantes aumentam consideravelmente seu consumo energético durante a lactação (Figura 35). 
Figura 35 - Acompanhamento da ingestão alimentar das lactantes $F_{1}$.

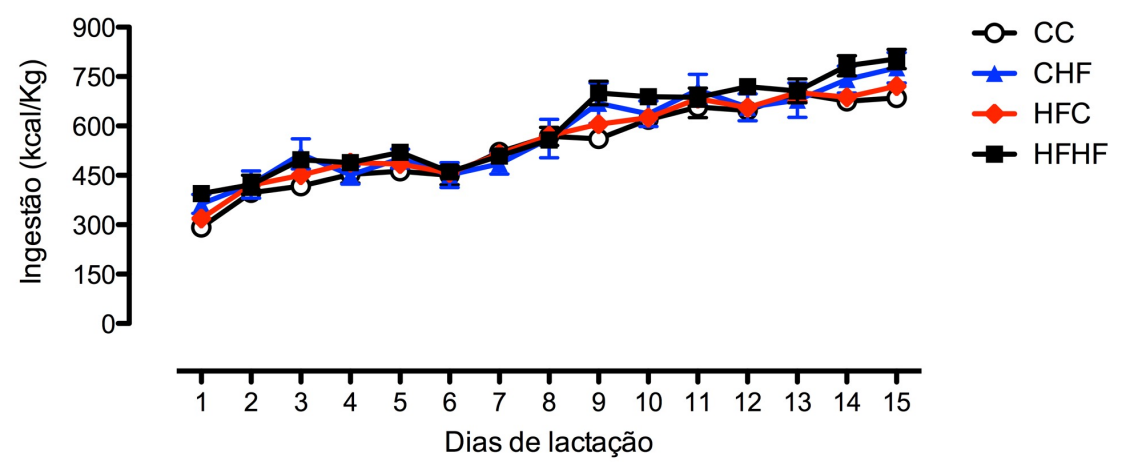

Os dados são expressos em média \pm E.P.M. CC (controle-controle): $n=8$; CHF (controlehiperlipídica): $\mathrm{n}=8$; HFC (hiperlipídica-controle): $\mathrm{n}=8$; HFHF (hiperlipídica-hiperlipídica): $\mathrm{n}=10$. ANOVA de duas vias. Efeito de tempo significante, $p<0,0001$.

Em relação aos testes metabólicos durante a lactação, as fêmeas responderam à injeção de insulina diminuindo seus níveis glicêmicos ao longo do tempo $(p<0,0001 ; F(5,150)=22,15)$. Entretanto, não houve diferença entre os grupos (Figura 36A). O mesmo aconteceu no TTOG, onde todas as fêmeas independentemente do grupo, elevaram seus níveis de glicemia sanguínea após a administração de glicose oral (efeito de tempo significante $p<0,0001 ; F(5,150)=$ 47,60), e restabeleceram os níveis basais ao final do teste (Figura 36B), não apresentado diferenças entre os grupos. A área sob a curva do TTOG também não revelou diferenças estatisticamente significantes entre os grupos (Figura 36C).

Figura 36 - Teste de tolerância à insulina (TTI), teste de tolerância oral à glicose (TTOG) e área sob a curva do TTOG (AUC) das lactantes $F_{1}$.

A $\quad m$

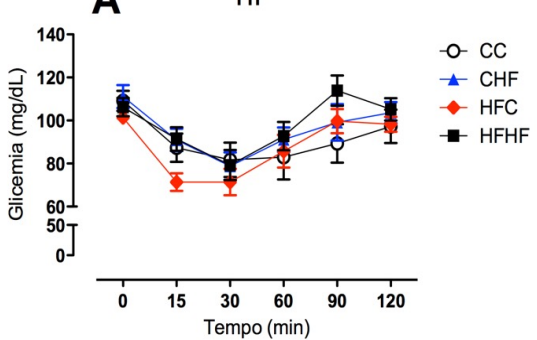

B тов

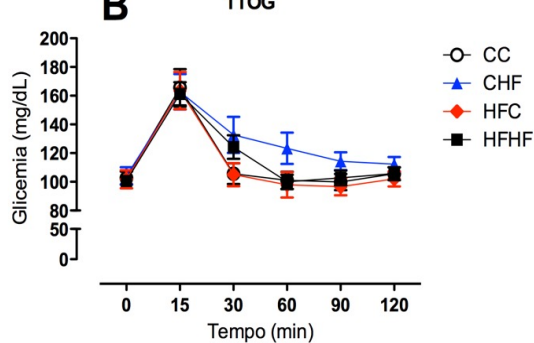

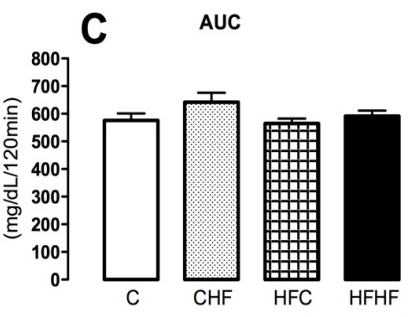

Os dados são expressos em média \pm E.P.M. CC (controle-controle): $n=8$; CHF (controlehiperlipídica): $n=8$; HFC (hiperlipídica-controle): $n=8$; HFHF (hiperlipídica-hiperlipídica): $n=10$. A. TTI realizado no DPN 6. ANOVA de duas vias. Efeito de tempo significante, $p<0,0001$. B. TTOG realizado no DPN 8. ANOVA de duas vias. Efeito de tempo significante, $p<0,0001$. C. AUC, ANOVA de uma via. 
Figura 37 - Duração da prenhez, número de filhotes e proporção de machos e fêmeas nas mães $F_{1}$.
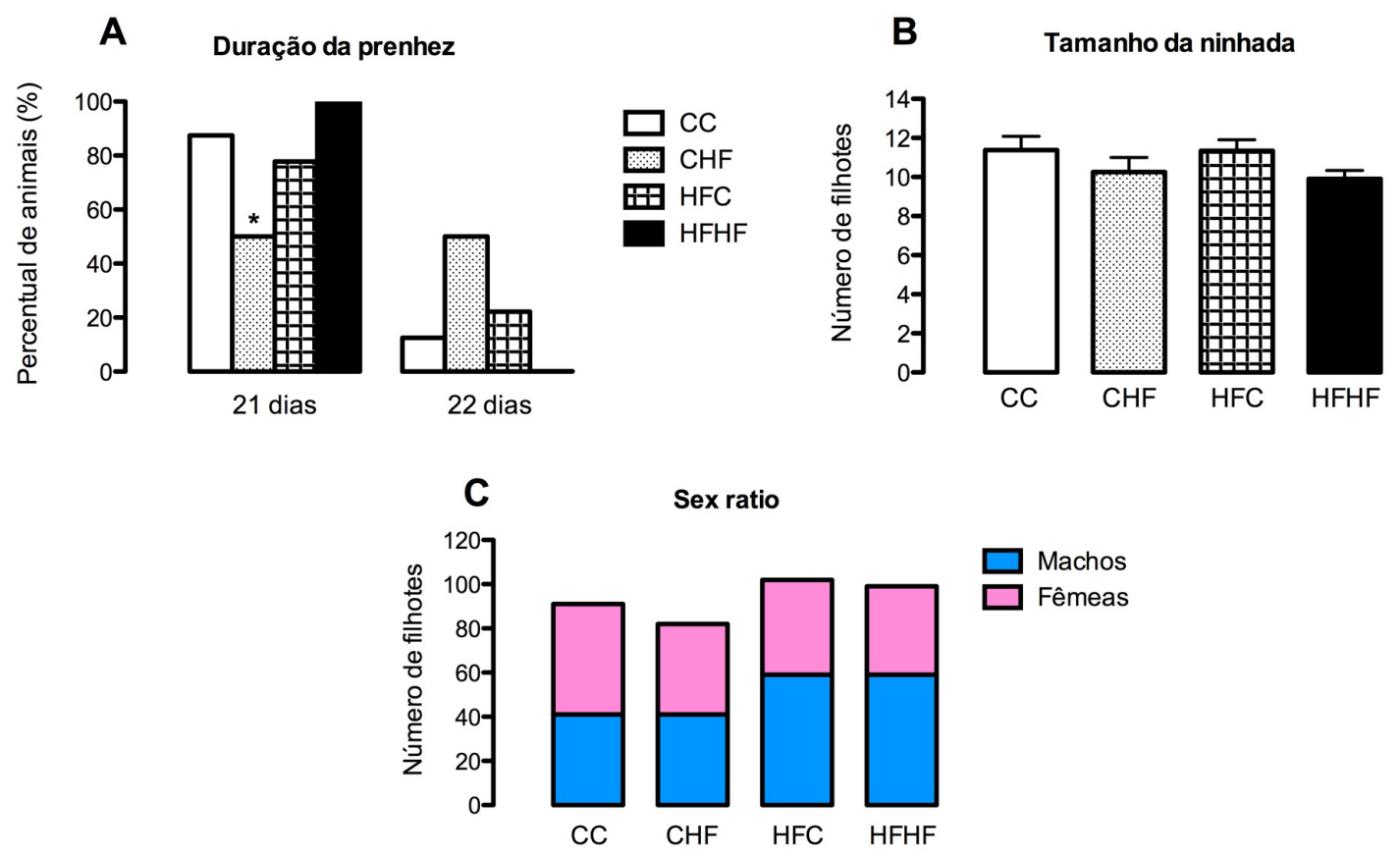

CC (controle-controle): $n=8$; CHF (controle-hiperlipídica): $n=8$; HFC (hiperlipídica-controle): $n=9$; HFHF (hiperlipídica-hiperlipídica): $n=10$. A. Dados expressos em percentual de mães que pariram aos 21 ou 22 dias de gestação. ${ }^{*} p<0,05$ para mães do CHF comparadas ao grupo HFHF. Teste de Fisher. B. Tamanho da ninhada. Dados expressos em média \pm E.PM. ANOVA de uma via. C. Proporção de machos e fêmeas nascidos em cada grupo. Dados expressos em número total de filhotes. ANOVA de uma via.

A duração da prenhez dos grupos da geração $F_{1}$ foi de 21 dias em sua maioria. Apenas o grupo CHF que teve $50 \%$ de suas fêmeas que pariram no $22^{\circ}$ dia. Isso gerou uma diferença estatisticamente significante quando comparado ao grupo HFHF, que teve $100 \%$ de suas fêmeas com parto aos 21 dias $(p<0,05$, Teste de Fisher - Figura 37A). Não houve diferenças entre os grupos em relação ao tamanho da ninhada e a proporção de machos e fêmeas nascidos de cada grupo $(p>0,05$, figuras 37B e $37 \mathrm{C}$ respectivamente).

\subsubsection{Comportamento materno - Geração $F_{1}$}

Os testes de comportamento materno das mães da geração $F_{1}$ foi realizado nos DPN 5 e 10. Inicialmente, são apresentados os dados do teste de 30 minutos, com separação das mães e dos filhotes antes do início do teste.

Não houve diferença na latência para busca do $1^{\circ}$ filhote, com as mães levando aproximadamente 60 segundos para buscá-los. Também não houve 
diferença na latência para busca do $5^{\circ}$ e $8^{\circ}$ filhotes pelas mães dos diferentes grupos (Figura 38).

Figura 38 - Latência para busca do $1^{\circ}(A), 5^{\circ}(B)$ e $8^{\circ}(C)$ filhotes no DPN 5 e 10 pelas mães da geração $F_{1}$.
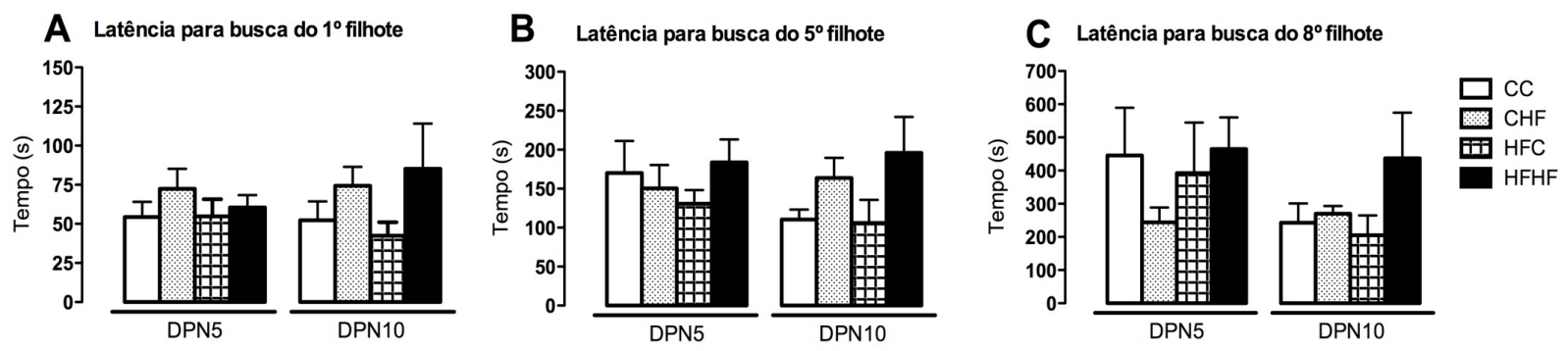

Dados expressos em média \pm E.P.M. CC (controle-controle): $n=8$; CHF (controle-hiperlipídica): $n=8$; HFC (hiperlipídica-controle): $n=8 ;$ HFHF (hiperlipídica-hiperlipídica): $n=10$. ANOVA de duas vias.

O número de buscas aos filhotes foi maior no DPN 5 não havendo diferença entre os grupos como mostra a figura 39A (efeito de tempo significante, $p<0,01$; $F(1,30)=7,430)$. O efeito de tempo também se mostrou significante no parâmetro de selfgrooming, sendo que as fêmeas realizam mais este comportamento no DPN 10 $(p<0,0001 ; F(1,30)=48,78$ - Figura 39B). Em relação ao tempo gasto agrupando os filhotes, as mães do grupo CHF passam mais tempo agrupando seus filhotes no DPN 5 quando comparadas aos grupo HFC e HFHF, e no DPN 10 quando comparadas ao grupo HFHF (efeito de grupo significante $p=0,0012 ; F(3,30)=6,889$ - Figura 39C). As mães gastam mais tempo lambendo seus filhotes (grooming dos filhotes) no $5^{\circ}$ dia de lactação, tendo efeito de tempo significante $(p=0,0313 ; F(1,30)$ $=5,105$. Este parâmetro também apresentou efeito da interação tempo $x$ grupo significante ( $p=0,0179 ; F(3,30)=3,921$ - Figura 39D).

As mães gastam mais tempo fora do ninho no DPN 5 (efeito de tempo significante $p<0,0001 ; F(1,30)=26,95)$ e não há diferenças em relação ao parâmetro de construção de ninho, como mostra a figura 40. 
Figura 39 - Parâmetros de número de buscas aos filhotes $(A)$, tempo gasto realizando selfgrooming das mamas $(B)$, tempo dispensado agrupando os filhotes (C) e tempo gasto lambendo (grooming) os filhotes (D) nos DPN 5 e 10 nas mães da geração $F_{1}$.
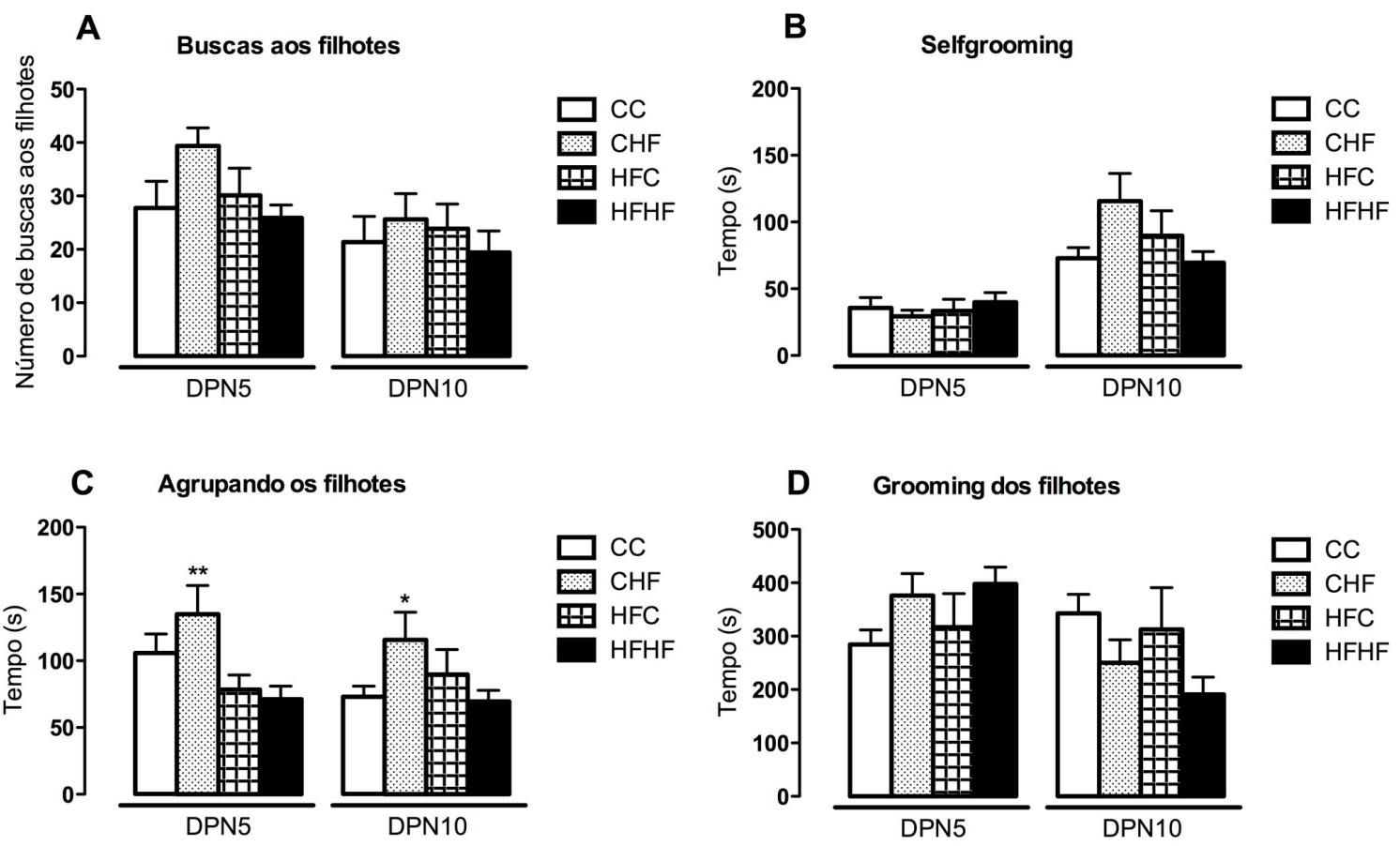

Os dados são expressos em média \pm E.P.M. CC (controle-controle): $\mathrm{n}=8$; CHF (controlehiperlipídica): $\mathrm{n}=8$; HFC (hiperlipídica-controle): $\mathrm{n}=8$; HFHF (hiperlipídica-hiperlipídica): $\mathrm{n}=10$. ANOVA de duas vias seguido pelo teste de Bonferroni. A. Efeito de tempo significante, $p<0,05$. B. Efeito de tempo significante, $p<0,0001$. C. Efeito de grupo significante, $p<0,01$. ${ }^{* *} p<0,05$ em relação aos grupos HFC e HFHF no DPN5. * $p<0,05$ comparado ao grupo HFHF no DPN 10. D. Efeito de tempo significante, $p<0,05$. Efeito de interação tempo $x$ grupo significante, $p<0,05$.

Figura 40 - Tempo que as mães da geração $F_{1}$ ficaram fora do ninho, longe dos filhotes (A) e tempo dispensado construindo o ninho (B).
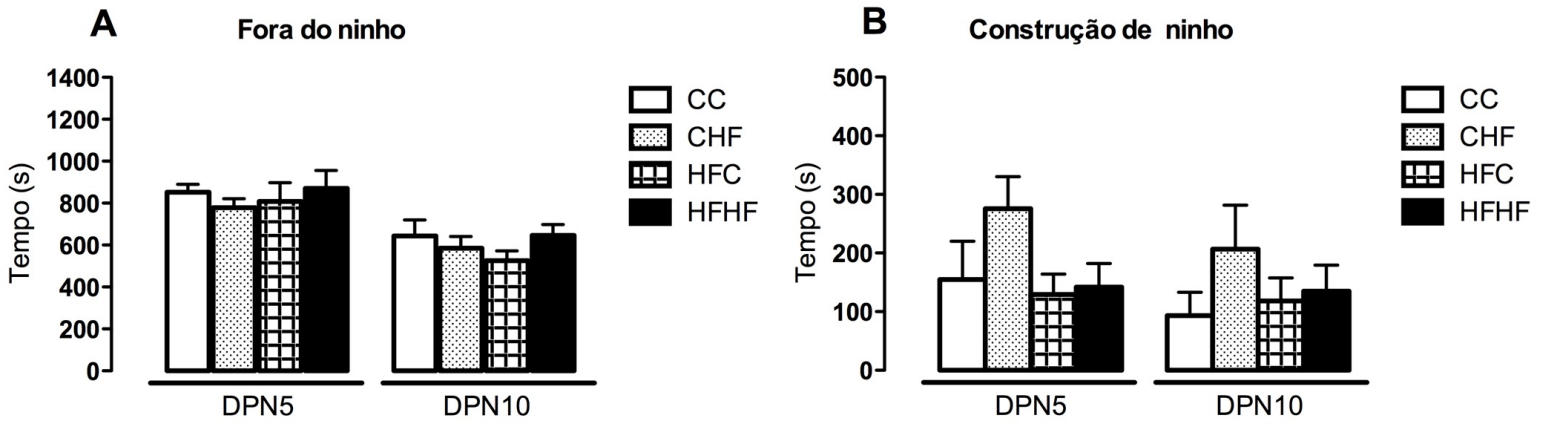

Os dados são expressos em média \pm E.P.M. CC (controle-controle): $n=8$; CHF (controlehiperlipídica): $\mathrm{n}=8$; HFC (hiperlipídica-controle): $\mathrm{n}=8$; HFHF (hiperlipídica-hiperlipídica): $\mathrm{n}=10$. A. Efeito de tempo significante, $p<0,0001$. ANOVA de duas vias. 
Figura 41 - Parâmetros de amamentação de 4 ou menos filhotes (A), 5 ou mais filhotes (B), amamentação dos filhotes em cifose fisiológica (crouching C) e comportamento materno total $(C M T)$ nas mães da geração $F_{1}$.

A

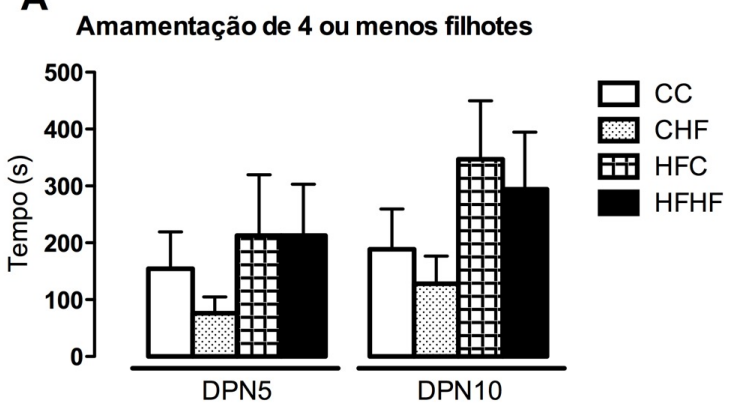

C

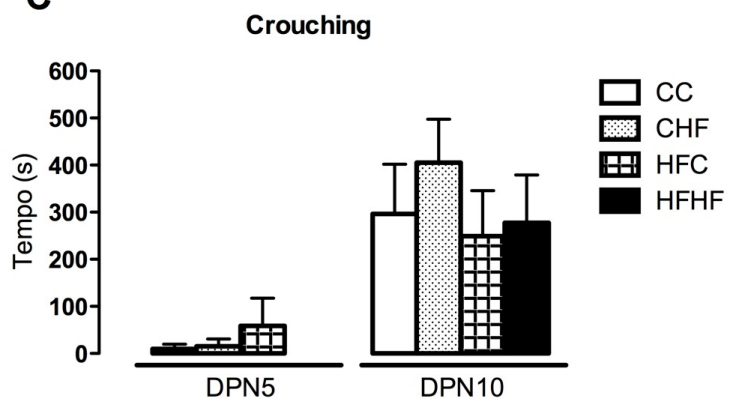

B

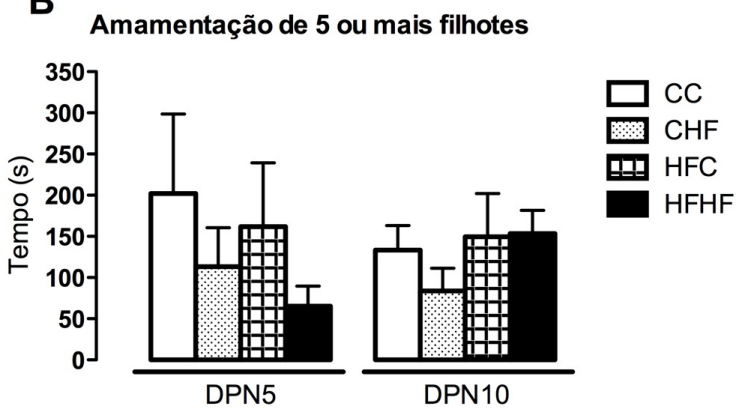

D

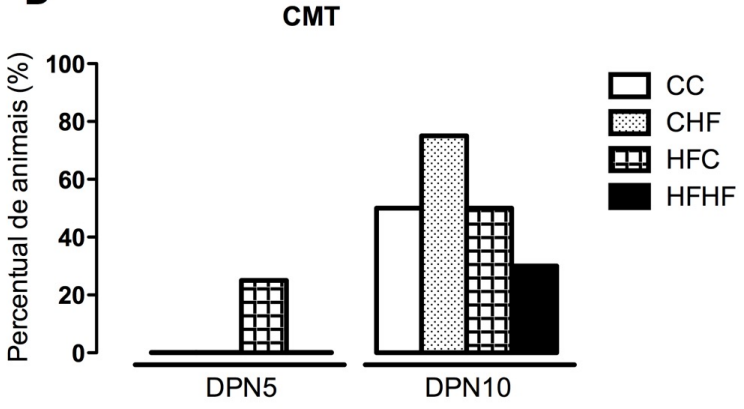

Os dados são expressos em média \pm E.P.M. CC (controle-controle): $\mathrm{n}=8$; CHF (controlehiperlipídica): $n=8$; HFC (hiperlipídica-controle): $n=8$; HFHF (hiperlipídica-hiperlipídica): $n=10$. ANOVA de duas vias. C. Efeito de tempo significante, $p<0,0001$. D. Efeito de tempo significante, $p<0,05$.

Não houve diferença estatística em relação aos parâmetros de amamentação de 4 ou menos filhotes, de 5 ou mais filhotes, ambos sem cifose, como mostram as figuras $41 \mathrm{~A}$ e $\mathrm{B}$ respectivamente.

As mães de todos os grupos passam mais tempo amamentando seus filhotes na posição de cifose fisiológica no DPN 10 (efeito de tempo significante $p<0,0001$; $F(1,30)=27,57)$ e o percentual de mães que realizam o comportamento materno total também é maior nesse dia $(p<0,0288 ; F(1,3)=15,57)$. Não houve diferença entre os grupos experimentais (Figuras 41C e D).

Os dados do comportamento materno realizado sem intervenção prévia nos filhotes são apresentados a seguir.

Não houve diferenças entre os grupos no tempo em que as mães ficaram ausentes do ninho e nem no tempo gasto o construindo (Figuras 42A e D), porém o número de vezes que elas visitam o mesmo é maior no DPN10 (efeito de tempo significante $p=0,0329 ; F(1,30)=5,004)$. Já em relação ao agrupamento dos filhotes, 
esse tempo é menor no DPN10 (efeito significante de tempo $p=0,0013 ; F(1,30)=$ 12,53 - Figuras 42B e C respectivamente).

Figura 42 - Parâmetros de comportamento materno analisados por 6 horas $-F_{1}$.
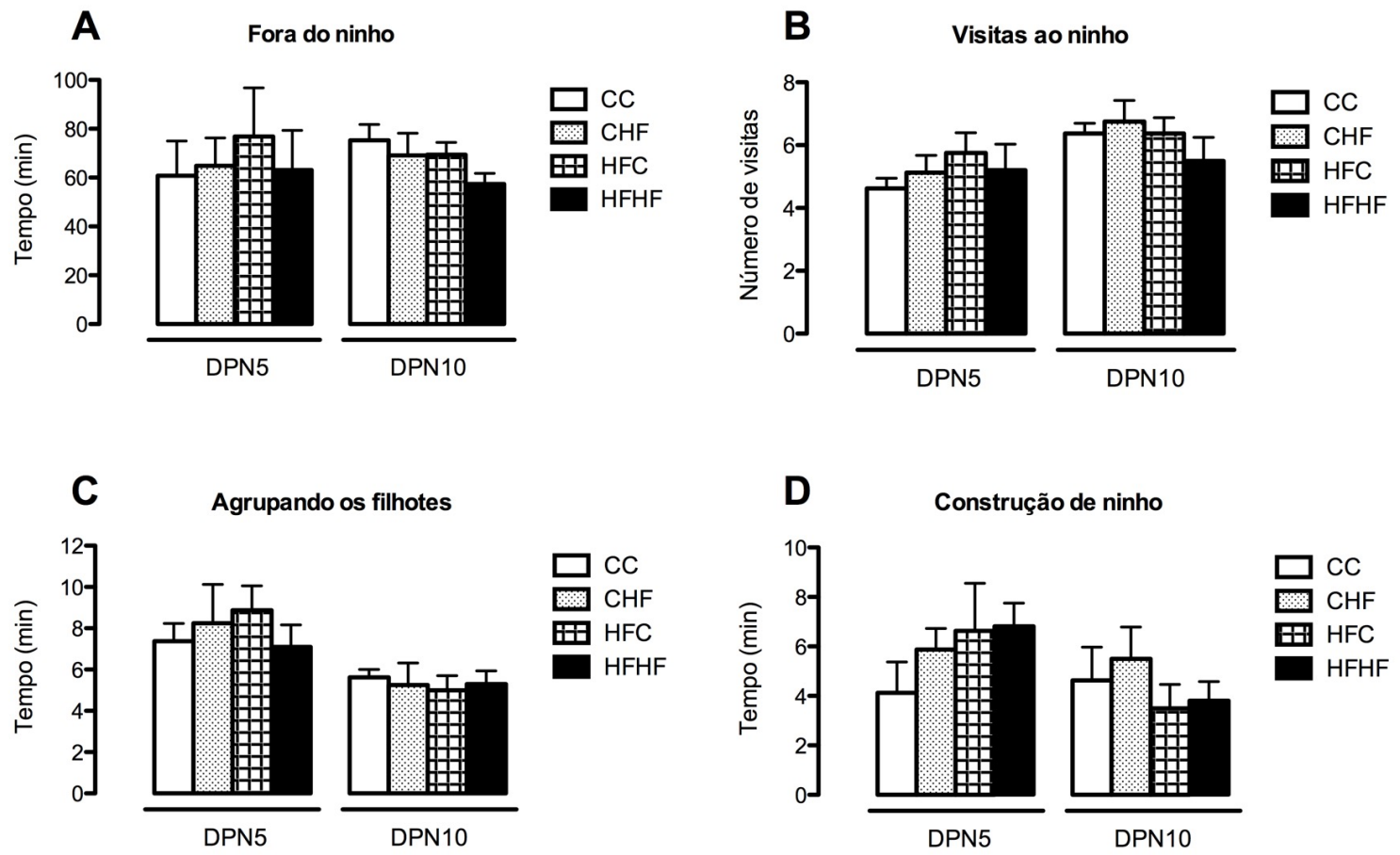

Os dados são expressos em média \pm E.P.M. CC (controle-controle): $n=8$; CHF (controlehiperlipídica): $n=8$; HFC (hiperlipídica-controle): $n=8$; HFHF (hiperlipídica-hiperlipídica): $\mathrm{n}=10$. ANOVA de duas vias. A. Tempo gasto fora do ninho. B. Número de vezes que a rata posiciona-se no ninho. Efeito de tempo significante, $p<0,05$. C. Tempo gasto agrupando os filhotes no ninho. Efeito de tempo significante, $p<0,05$. D. Tempo usado para construção do ninho.

Os parâmetros de crouching (amamentação em cifose), amamentação sem cifose e selfgrooming não apresentaram diferenças estatisticamente significantes, como mostra a figura $43(p>0,05)$. As mães gastam mais tempo fazendo grooming dos filhotes no DPN5 (efeito de tempo significante $p=0,005 ; F(1,30)=15,12$ ).

As lactantes, de todos os grupos e em ambos os dias analisados, têm o maior período de permanência na posição de cifose em torno de 45 minutos (2700 s Figura 44A). A latência para a primeira ejeção é maior no grupo HFHF comparado ao grupo controle no DPN5, e maior que todos os demais grupo no DPN10 (efeito de grupo significante $p<0,001 ; F(3,30)=13,56$ - Figura 44B). 
Figura 43 - Selfgrooming, grooming dos filhotes e amamentação com e sem cifose nas mães da geração $F_{1}$.
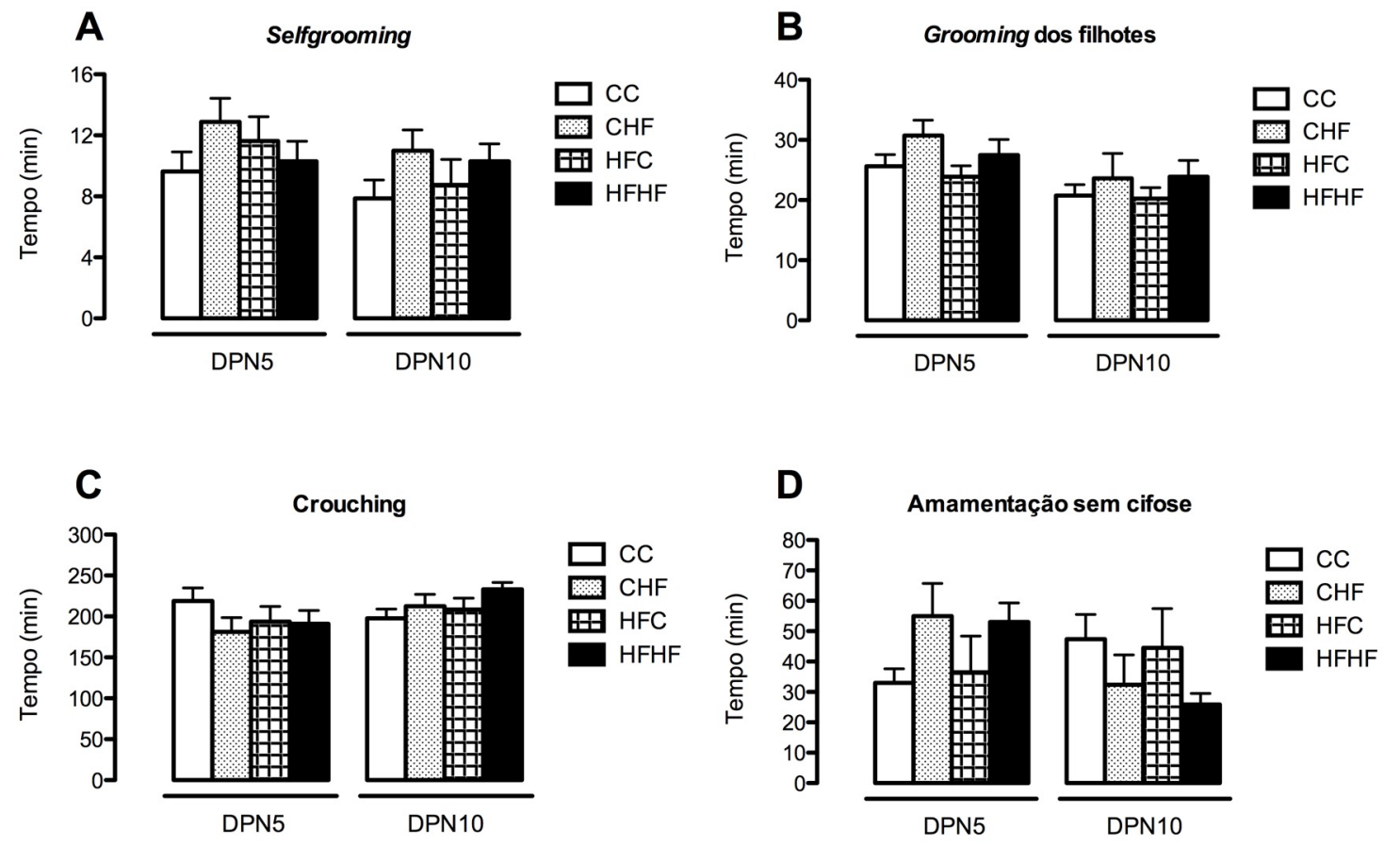

Os dados são expressos em média \pm E.P.M. CC (controle-controle): $n=8 ; \mathrm{CHF}$ (controlehiperlipídica): $n=8$; HFC (hiperlipídica-controle): $n=8$; HFHF (hiperlipídica-hiperlipídica): $n=10$. ANOVA de duas vias. A. Tempo gasto realizando autolimpeza. B. Tempo usado realizando grooming nos filhotes. Efeito de tempo significante, $p<0,001$. C. Tempo amamentando em cifose. D. Tempo amamentando em outra posição que não cifose.

Todos os grupos que receberam dieta hiperlipídica em algum período da vida (CHF, HFC e HFHF) mostraram um número significativamente menor de ejeções que o grupo controle (CC) no DPN5 (Figura 44C - efeito de grupo dignificante $p=0,0014 ; F(3,30)=6,655)$.

O intervalo médio entre uma ejeção e outra (figura 44D) foi maior nos grupo CHF e HFHF comparados ao grupo controle no DPN5. Entretanto, no DPN10 o grupo HFHF mostrou um intervalo significativamente maior que os grupos $\mathrm{CC}$ e $\mathrm{CHF}$ (efeito de grupo significante $p=0,0022 ; F(3,30)=6,168$ ). 
Figura 44 - Parâmetros de tempo de amamentação e ejeções de leite - $F_{1}$.
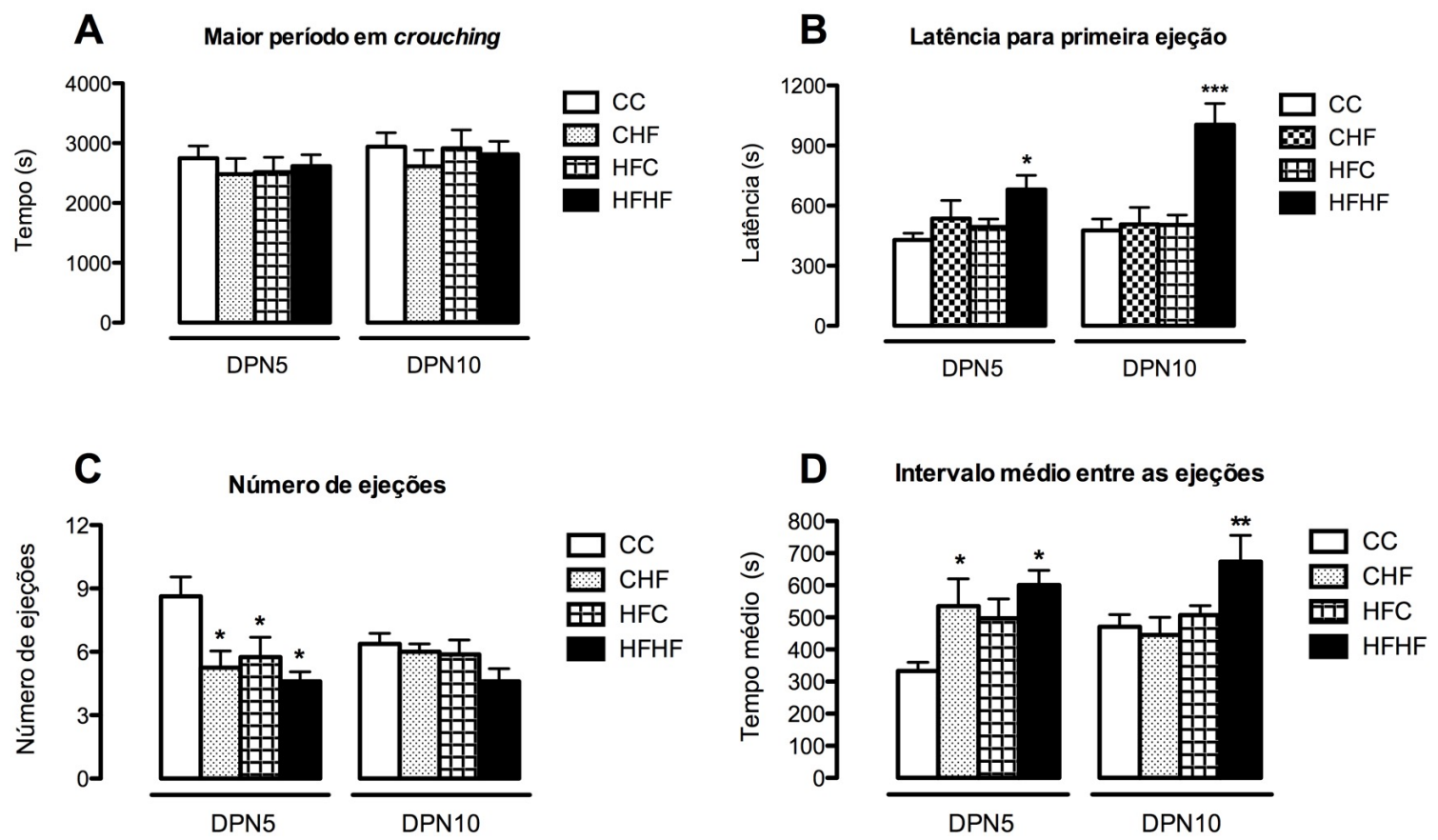

Os dados são expressos em média \pm E.P.M. CC (controle-controle): $n=8$; CHF (controlehiperlipídica): $\mathrm{n}=8$; HFC (hiperlipídica-controle): $\mathrm{n}=8$; HFHF (hiperlipídica-hiperlipídica): $\mathrm{n}=10$. ANOVA de duas vias seguida pelo teste de Bonferroni. A. Maior período em amamentação na posição de cifose. B. Latência para a primeira ejeção de leite. Efeito significante de grupo, $p<0,0001$. C. Número de ejeções no maior período em crouching. Efeito de grupo significante, $p<0,01$. D. Intervalo médio entre as ejeções. Efeito de grupo significante, $p<0,01 .{ }^{*} p<0,05$ comparado ao grupo CC. ${ }^{* *} \mathrm{p}<0,05$ comparado aos grupos $\mathrm{CC}$ e CHF. ${ }^{* * *} \mathrm{p}<0,001$ comparado a todos os demais grupos.

\subsubsection{Análises bioquímicas e hormonais das mães - Geração $F_{1}$}

No DPN21, logo após o desmame, o soro das mães foi coletado para realização de análises bioquímicas (Tabela 10). As mães do grupo CHF e HFHF apresentaram níveis de elevados de colesterol total quando comparados aos grupos CC e HFC $(p<0,0001 ; F(3,30)=26,76)$. Consistentemente, os níveis de LDLcolesterol nos grupos CHF e HFHF estavam elevados quando comparados aos grupos que receberam dieta padrão desde o seu desmame (CC e HFC) $(p<0,0001$; $K=22,73$ ). A enzima alanina amino transferase (ALT) teve seus níveis no grupo HFHF aumentados em relação a todos os demais grupos $(p<0,0001 ; F(3,30)=$ $12,24)$. 
Tabela 10 - Parâmetros bioquímicos das mães (geração $F_{1}$ ) no DPN21 - dia do desmame.

\begin{tabular}{|c|c|c|c|c|}
\hline \multirow{2}{*}{ Parâmetros } & \multicolumn{4}{|c|}{ Grupos } \\
\hline & $C C$ & $\mathrm{CHF}$ & HFC & HFHF \\
\hline $\begin{array}{l}\text { Colesterol } \\
(\mathrm{mg} / \mathrm{dL})\end{array}$ & $90,6 \pm 2,1$ & $116,7 \pm 3,3^{* *}$ & $90,3 \pm 2,9$ & $114,1 \pm 2,3^{* *}$ \\
\hline $\begin{array}{c}\text { HDL-colesterol } \\
\text { (mg/dL) }\end{array}$ & $41,9 \pm 2,7$ & $49,0 \pm 3,6$ & $36,8 \pm 2,9$ & $43,8 \pm 2,7$ \\
\hline $\begin{array}{l}\text { LDL-colesterol } \\
\qquad(\mathrm{mg} / \mathrm{dL})\end{array}$ & $20,9 \pm 0,8$ & $33,6 \pm 1,6^{*}$ & $22,3 \pm 0,9$ & $32,4 \pm 2,3^{*}$ \\
\hline $\begin{array}{c}\text { Triglicérides } \\
\text { (mg/dL) }\end{array}$ & $92,1 \pm 3,0$ & $93,6 \pm 3,5$ & $100,0 \pm 4,0$ & $89,1 \pm 2,4$ \\
\hline AST (U/L) & $176,7 \pm 25,5$ & $190,6 \pm 20,0$ & $180,4 \pm 12,4$ & $177,6 \pm 15,9$ \\
\hline $\mathrm{ALT}(\mathrm{U} / \mathrm{L})$ & $87,2 \pm 12,6$ & $93,5 \pm 14,2$ & $83,9 \pm 8,0$ & $171,8 \pm 13,7^{* * *}$ \\
\hline
\end{tabular}

Os dados são expressos em média \pm E.P.M. CC (controle-controle): $n=8$; CHF (controlehiperlipídica): $n=8$; HFC (hiperlipídica-controle): $n=8$; HFHF (hiperlipídica-hiperlipídica): $n=10$. ${ }^{*} p<0,0001$ comparado aos grupos CC e HFC. Como a análise de variância amostral mostrou-se significante, neste teste foi usado a ANOVA de uma via não-paramétrica (Teste de Kruskall-Wallis) seguida pelo tesde de Dunn. ${ }^{* *} p<0,0001$ comparados aos grupos CC e HFC; ${ }^{* * *} p<0,0001$ comparado aos grupos CC, CHF e HFC, ANOVA de uma via seguida pelo teste de Tukey.

Também foram realizadas dosagens séricas dos hormônios insulina e leptina. Os resultados são mostrados na figura 45.

Os níveis de insulina mostraram-se similares em todos os grupos estudados $(p>0,05)$. Entretanto, a dosagem de leptina nos grupos CHF e HFHF apresentou-se significativamente menor que os grupos CC e HFC $(p=0,002 ; F(3,20)=10,50)$.

Figura 45 - Dosagem sérica de insulina $(A)$ e leptina $(B)$ nas mães $F_{1}$ no DPN21.

A

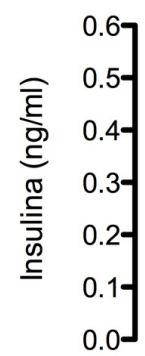

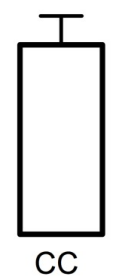

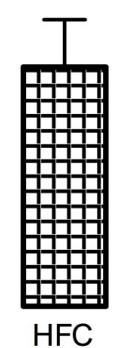

B

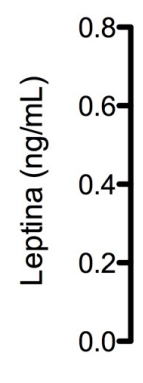

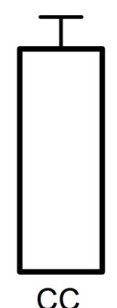
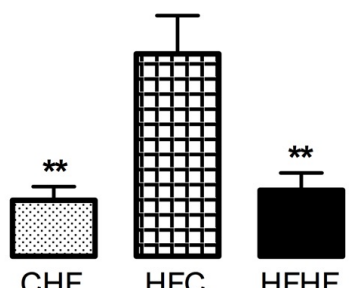

Os dados são expressos em média \pm E.P.M. CC (controle-controle): $n=6$; CHF (controlehiperlipídica): $\mathrm{n}=6$; HFC (hiperlipídica-controle): $\mathrm{n}=6$; HFHF (hiperlipídica-hiperlipídica): $\mathrm{n}=6$. ANOVA de uma via seguida pelo teste de Tukey, $p<0,01 .{ }^{* *} p<0,01$ comparados aos grupos CC e HFC. 


\subsubsection{Análises moleculares - Geração $F_{1}$}

A figura 46 mostra os dados de expressão dos genes Oprm1, Oprk1 e Oprd1 e das proteínas MOR, KOR e DOR que codificam os receptores opióides $\mu, \mathrm{k}$ e $\delta$, respectivamente. A expressão do gene Oprm1 mostra-se diferente entre cada grupo, sendo maior nos grupos CHF e HFHF (Figura 46A). Porém, ambos também são diferentes entre si, com HFHF apresentando maior expressão que todos os demais grupos $(p<0,0001 ; F(3,17)=553,5)$.

Figura 46 - Análise da expressão dos genes Oprm1, Oprk1 e Oprd1 por qPCR e da expressão protéica MOR, KOR e DOR por Western Blotting nas mães da geração $F_{1}$.

A

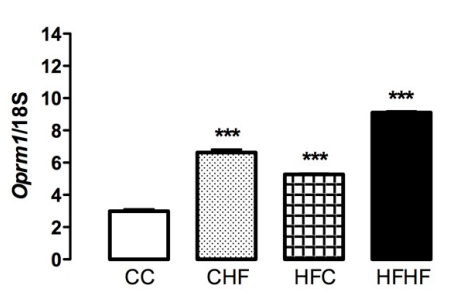

D

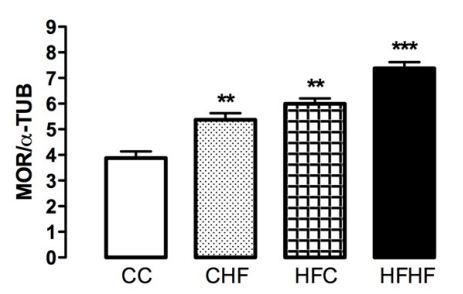

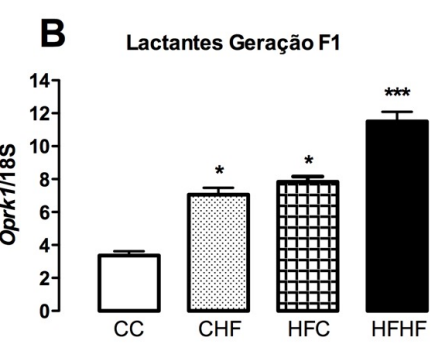
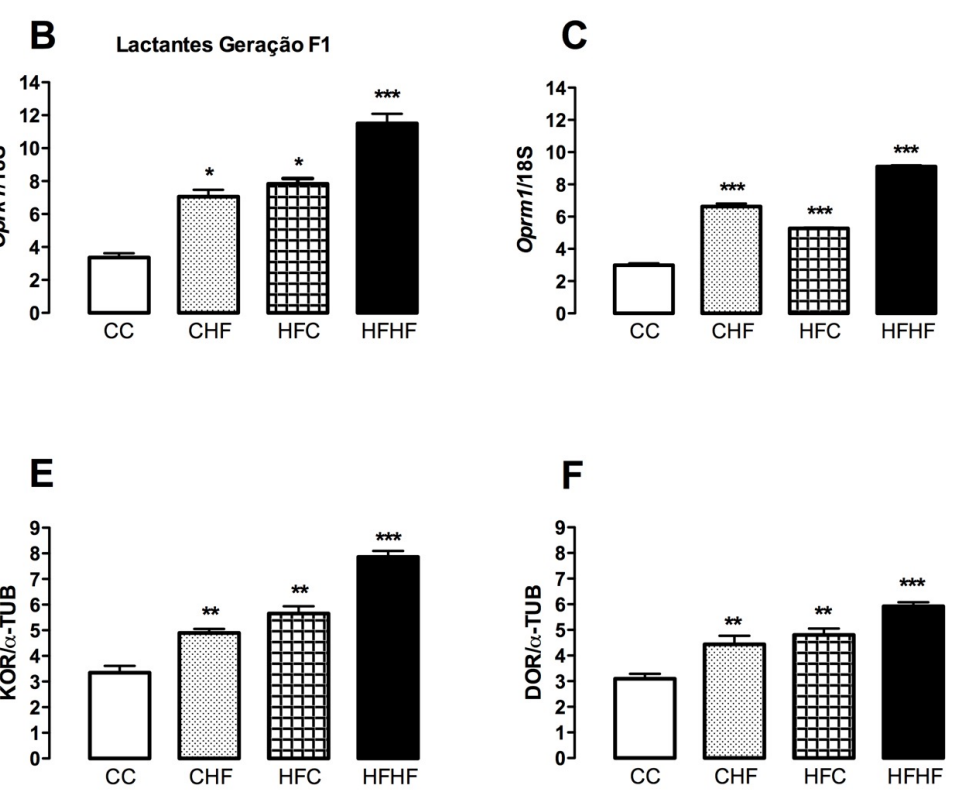

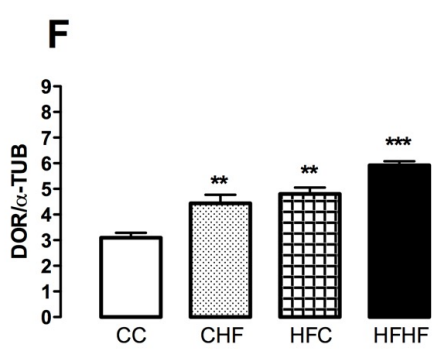

Os dados são expressos em média \pm E.P.M. CC (controle-controle): $n=5$; CHF (controlehiperlipídica): $\mathrm{n}=4$; HFC (hiperlipídica-controle): $\mathrm{n}=4$; HFHF (hiperlipídica-hiperlipídica): $\mathrm{n}=5$. A, B e C apresentam os dados dos produtos de expressão gênica Oprm1, Oprk1 e Oprd1, respectivamente, por qPCR de RNA total extraído do hipotálamo dos animais de cada grupo em relação ao gene $18 \mathrm{~S}$ de expressão constitutiva. ANOVA de uma via seguida pelo teste de Tukey. ${ }^{* *} p<0,0001$ em relação a todos os demais grupos; ${ }^{* *} p<0,0001$ comparado aos grupos CC e CHF; ${ }^{*} p<0,0001$ comparado ao grupo CC. D, E e F apresentam a imuno-reatividade para as proteínas que codificam os receptores $\mu$, $\mathrm{K}$ e $\delta$ opióides (Western Blotting). Os dados são expressos como a razão da intensidade densitométrica da banda imuno-reativa para cada um dos receptores opióides divididos pela banda de imuno-reatividade da $\alpha$-tubulina. ANOVA de uma via com pós-teste de Tukey. ${ }^{* *} p<0,0001$ comparado ao grupo $\mathrm{CC} ;{ }^{* * *} \mathrm{p}<0,0001$ em relação a todos os demais grupos.

Em relação ao gene Oprk1, o grupo HFHF apresentou expressão mais elevada, sendo diferente de todos os demais grupos (Figura 46B). Os animais dos grupos CHF e HFC também apresentaram maior expressão desse gene quando comparados ao grupo controle, CC $(p<0,0001 ; F(3,17)=66,83)$. No grupo HFHF, a 
expressão do gene Oprd1 foi maior em relação ao grupo CC e CHF (Figura 46C). As mães dos grupos CHF e HFC também apresentam maior expressão desse gene no hipotálamo quando comparados ao grupo $C C(p<0,0001 ; F(3,17)=53,25)$.

A expressão das proteínas MOR, KOR e DOR (Figuras 46D, 46E e 46F, respectivamente), que codificam os receptores opióides $\mu, \mathrm{k}$ e $\delta$, apresentou-se maior no grupo HFHF comparado com todos os demais grupos, enquanto que os grupos CHF e HFC apresentaram expressão maior que as mães do grupo CC $($ MOR: $p<0,0001 ; F(3,15)=38,72 ;$ KOR $p<0,0001 ; F(3,15)=62,24 ; D O R: p<0,0001$; $F(3,15)=31,26)$.

4.3.4 Peso corporal, peso do fígado e do tecido adiposo no DPN 21 das mães Geração $F_{1}$

A tabela 11 apresenta os dados de peso corporal, peso do fígado e peso dos tecidos adiposos retroperitoneal e retrogonadal das mães da geração $F_{1}$ logo após o desmame, no DPN21.

Tabela 11 - Peso corporal e dos órgãos das mães da geração $F_{1}$ após o desmame no DPN21.

\begin{tabular}{ccccc}
\hline \multirow{2}{*}{ Parâmetros } & \multicolumn{4}{c}{ Grupos } \\
\cline { 2 - 5 } & $\mathrm{CC}$ & $\mathrm{CHF}$ & HFC & HFHF \\
\hline Peso corporal $(\mathrm{g})$ & $279,1 \pm 6,0$ & $248,6 \pm 4,7^{* *}$ & $282,1 \pm 6,4$ & $242,6 \pm 3,7^{* *}$ \\
Fígado $(\mathrm{g})$ & $13,3 \pm 0,49$ & $11,42 \pm 0,39^{*}$ & $12,8 \pm 0,48$ & $10,5 \pm 0,33^{* *}$ \\
$\begin{array}{c}\text { Tec. adiposo } \\
\text { retroperitoneal }(\mathrm{g}) \\
\text { Tec. adiposo }\end{array}$ & $0,61 \pm 0,74$ & $0,56 \pm 0,11$ & $1,00 \pm 0,13^{\#}$ & $0,65 \pm 0,08$ \\
retrogonadal $(\mathrm{g})$ & $1,25 \pm 0,14$ & $1,16 \pm 0,30$ & $2,02 \pm 0,28$ & $1,25 \pm 0,19$ \\
\hline
\end{tabular}

Os dados são expressos em média \pm E.P.M. CC (controle-controle): $n=8$; CHF (controlehiperlipídica): $\mathrm{n}=8$; HFC (hiperlipídica-controle): $\mathrm{n}=8$; HFHF (hiperlipídica-hiperlipídica): $\mathrm{n}=10$. ANOVA de uma via seguida pelo teste de Tukey. ${ }^{*} p<0,05$ comparado ao grupo controle; ${ }^{* *} p<0,05 \mathrm{em}$ relação aos grupos CC e HFC; \#p<0,05 comparado ao grupo CHF.

As lactantes dos grupos CHF e HFHF têm peso menor que os grupos CC e HFC no DPN $21(p<0,0001 ; F(3,30)=15,84)$. O peso do fígado dos animais do grupo HFHF foi menor se comparado ao grupo CC e HFC, e esse mesmo órgão nos animais CHF eram menores do que nas mães CC $(p<0,0001 ; F(3,30)=9,663)$. 
Entretanto, quando fazemos o peso do fígado em relação ao peso corporal, por essas fêmeas pesarem menos, a diferença do peso do fígado desaparece $(p>0,05)$.

A quantidade de gordura retroperitoneal presente no grupo HFC era maior do que no grupo $\operatorname{CHF}(p=0,0184 ; F(3,30)=3,892)$ na final da lactação. Em relação à gordura perigonadal, houve uma tendência ao efeito entre os grupos $(p=0,0575$; $F(3,30)=2,79)$, sendo a quantidade desse tecido no grupo HFC maior que nos demais.

\subsubsection{Análises dos filhotes - Geração $F_{2}$}

Durante a lactação (DPN1 ao 21), também foram acompanhados parâmetros de desenvolvimento dos filhotes, que são mostrados a seguir.

No DPN1, os neonatos foram classificados de acordo com seu peso ao nascimento (Figura 47). Ao menos $75 \%$ dos filhotes em cada grupo estavam com o peso adequado para idade gestacional, não apresentando diferenças significativas entre os grupos $(p>0,05)$.

Figura 47 - Classificação dos neonatos de acordo com o peso ao nascimento - $F_{2}$.

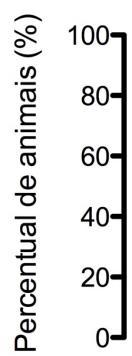

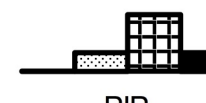

PIP
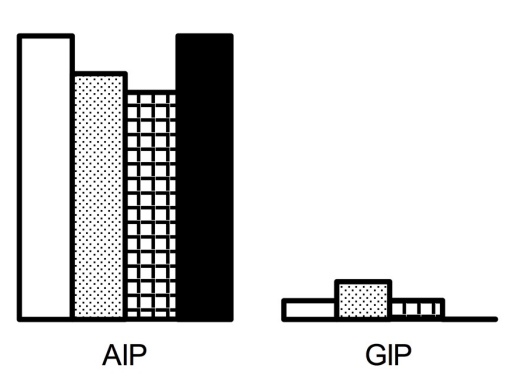

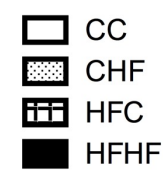

Os dados são expressos em percentual de animais classificados em cada categoria. CC (controlecontrole): $n=16$; CHF (controle-hiperlipídica): $n=16$; HFC (hiperlipídica-controle): $n=16$; HFHF (hiperlipídica-hiperlipídica): $n=20$. PIP: pequeno para idade de prenhez; AIP: adequado para a idade de prenhez; GIP: grande para a idade de prenhez. Teste de Fisher.

O ganho de peso diário dos filhotes das mães da geração $F_{1}$ durante a lactação também foi acompanhado, como mostra a figura 48. A geração $F_{2}$ apresentou efeito significante de tempo nesse parâmetro, como esperado $(p<0,0001 ; F(20,600)=3640)$. Os descendentes de cada grupo responderam de forma diferente ao longo do tempo, o que foi evidenciado com o efeito da interação tempo $x$ grupo significante $(p<0,0001 ; F(60,600)=2,702)$. Houve ainda efeito de 
grupo significante $(p=0,0376 ; F(3,30)=3,195)$. A ninhada do grupo HFHF mostrou aumento de peso menor do que o grupo controle a partir do $14^{\circ}$ dia de lactação até o final da mesma. No DPN 18, o ganho de peso do grupo HFHF passou a ser significativamente menor que o grupo HFC, e essa diferença persistiu até o fim da lactação. No dia do desmame (DPN 21), a ninhada de HFHF pesava $288,4 \mathrm{~g}$, enquanto que CC 318,8g, HFC 316,0g e CHF 307,9g.

Figura 48 - Ganho de peso da ninhada da geração $F_{2}$ durante a lactação.

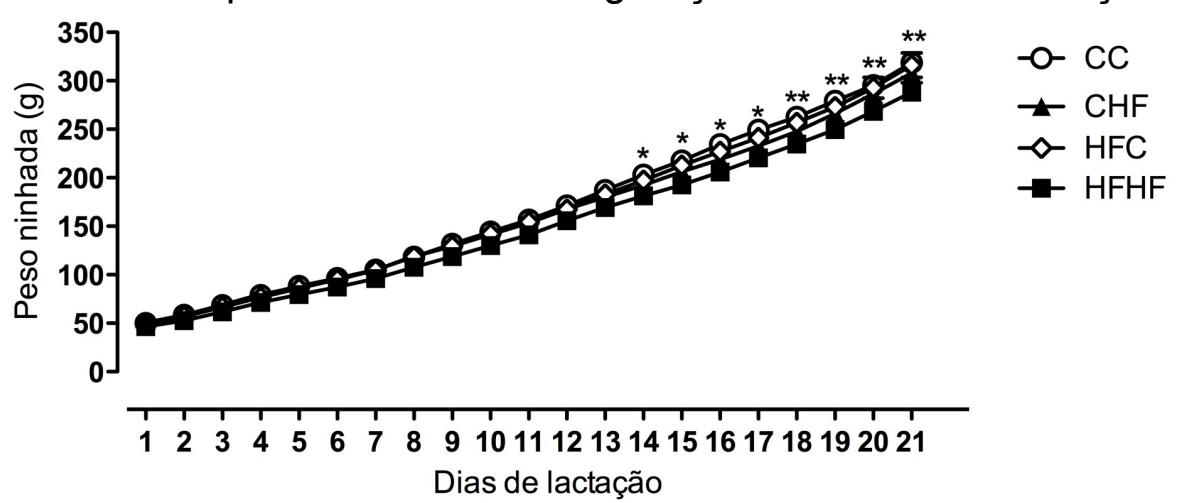

Dados expressos em média \pm E.P.M. CC (controle-controle): $n=8$; CHF (controle-hiperlipídica): $n=8$; HFC (hiperlipídica-controle): $n=8$; HFHF (hiperlipídica-hiperlipídica): $n=10$. ANOVA de duas vias seguida pelo teste de Bonferroni. Efeito de tempo significante, $p<0,0001$. Efeito de interação tempo $x$ grupo significante, $p<0,0001$. Efeito de grupo significante, $p<0,05 .{ }^{*}$ indica $p<0,05$ para o grupo HFHF comparado ao grupo CC. ${ }^{* *}$ indica $p<0,05$ para o grupo HFHF em relação aos grupos CC e HFC.

Além do peso conjunto da ninhada, também foi acompanhado o peso corpóreo individual e o comprimento corporal dos machos e fêmeas no DPN1, 10 e 21. A distância ano-genital também foi medida no DPN 1 e 21 . Os filhotes machos de todos os grupos pesavam aproximadamente $6 \mathrm{~g}$ no DPN1 (Tabela 12). Porém, no final da lactação as diferenças entre os grupos apareceram e os filhotes dos grupos CHF e HFHF pesavam menos que os grupos CC e HFC no DPN21, apresentando efeito de grupo significante $(p=0,0021 ; F(3,30)=6,206)$. Houve efeito de interação tempo x grupo significante $(p=0,0105 ; F(6,60)=3,091)$. O efeito do tempo também foi significante, conforme era esperado $(p<0,0001 ; F(2,60)=3088)$. Em relação ao comprimento corporal (naso-anal) e a distância ano-genital, de acordo com o esperado, o efeito do tempo foi significante $(p<0,0001 ; F(2,30)=4888$ e $p<0,0001$; $F(1,30)=4639$, respectivamente) . 
Tabela 12 - Peso corporal, comprimento corporal e distância ano-genital dos filhotes machos da geração $F_{2}$ durante a lactação.

\begin{tabular}{cccccc}
\hline \multirow{2}{*}{ Parâmetros } & \multirow{2}{*}{ Machos } & \multicolumn{5}{c}{ Grupos } \\
\cline { 3 - 6 } & & $C C$ & $C H F$ & $H F C$ & $H F H F$ \\
\hline \multirow{2}{*}{ Peso } & DPN 1 & $6,44 \pm 0,28$ & $6,39 \pm 0,26$ & $6,27 \pm 0,29$ & $5,91 \pm 0,06$ \\
corporal (g) & DPN 10 & $18,51 \pm 0,68$ & $16,19 \pm 0,65$ & $17,99 \pm 0,35$ & $16,34 \pm 0,33$ \\
& DPN 21 & $40,37 \pm 0,97$ & $37,41 \pm 1,52^{*}$ & $40,20 \pm 0,91$ & $36,09 \pm 0,58^{*}$ \\
Comprimento & DPN 1 & $4,90 \pm 0,12$ & $4,96 \pm 0,09$ & $4,88 \pm 0,10$ & $4,74 \pm 0,03$ \\
corporal (cm) & DPN 10 & $7,25 \pm 0,12$ & $7,17 \pm 0,09$ & $7,15 \pm 0,10$ & $6,92 \pm 0,05$ \\
\cline { 3 - 6 } Distância & DPN 21 & $10,13 \pm 0,17$ & $10,06 \pm 0,17$ & $10,13 \pm 0,08$ & $9,77 \pm 0,11$ \\
ano-genital & DPN 1 & $0,37 \pm 0,01$ & $0,37 \pm 0,02$ & $0,36 \pm 0,02$ & $0,35 \pm 0,01$ \\
\cline { 3 - 6 } (cm) & DPN 21 & $1,51 \pm 0,03$ & $1,51 \pm 0,04$ & $1,50 \pm 0,03$ & $1,42 \pm 0,02$ \\
\hline
\end{tabular}

Dados expressos em média \pm E.P.M. CC (controle-controle): $n=8$; CHF (controle-hiperlipídica): $n=8$; HFC (hiperlipídica-controle): $\mathrm{n}=8$; HFHF (hiperlipídica-hiperlipídica): $\mathrm{n}=10$. ANOVA de duas vias seguida pelo teste de Bonferroni. Efeito de tempo significante para os 3 parâmetros, $p<0,05$. Efeito de interação tempo x grupo eficiente para o peso corporal, $p<0,05$. ${ }^{*} p<0,05$ comparado aos grupos $C C$ e HFC.

Os ganho de peso dos filhotes fêmeas foi estatisticamente significante ao longo do tempo, como esperado $(p<0,0001 ; F(2,60)=3806)$. Houve também efeito de interação tempo x grupo $(p=0,0113 ; F(6,60)=3,053)$. O efeito de grupo apresentou uma tendência a ser estatisticamente significante no peso corporal desses filhotes durante a lactação $(p=0,0558 ; F(3,30)=2,819)$, como pode ser observado na tabela 13.

O comprimento corporal das fêmeas do grupo HFHF foi menor comparado aos grupos CC e HFC no DPN 21 ( $p=0,0371 ; F(3,30)=3,206$ ). De acordo com o previsto, o efeito de tempo foi significante sob o comprimento corporal $(p<0,0001$; $F(2,60)=3934)$ e a distância ano-genital $(p<0,0001 ; F(1,30)=5908)$. O efeito da interação tempo $x$ grupo também sem mostrou significante na distância ano-genital das fêmeas $(p=0,0401 ; F(3,30)=3,132)$. 
Tabela 13 - Peso corporal, comprimento corporal e distância ano-genital dos filhotes fêmeas da geração $F_{2}$ durante a lactação.

\begin{tabular}{cccccc}
\hline \multirow{2}{*}{ Parâmetros } & \multirow{2}{*}{ Fêmeas } & \multicolumn{4}{c}{ Grupos } \\
\cline { 3 - 6 } & & $C C$ & $C H F$ & $H F C$ & $H F H F$ \\
\hline \multirow{2}{*}{ Peso } & DPN 1 & $6,20 \pm 0,20$ & $6,12 \pm 0,28$ & $6,02 \pm 0,36$ & $5,63 \pm 0,09$ \\
corporal (g) & DPN 10 & $18,2 \pm 0,75$ & $17,5 \pm 0,80$ & $17,54 \pm 0,67$ & $16,05 \pm 0,23$ \\
& DPN 21 & $39,0 \pm 1,39$ & $37,8 \pm 1,29$ & $40,13 \pm 1,04$ & $35,74 \pm 0,67$ \\
Comprimento & DPN 1 & $4,86 \pm 0,12$ & $4,76 \pm 0,09$ & $4,77 \pm 0,14$ & $4,61 \pm 0,02$ \\
corporal (cm) & DPN 10 & $7,14 \pm 0,09$ & $7,18 \pm 0,11$ & $7,16 \pm 0,10$ & $6,86 \pm 0,08$ \\
Distância & DPN 21 & $10,09 \pm 0,16$ & $9,81 \pm 0,18$ & $10,08 \pm 0,09$ & $9,62 \pm 0,10^{*}$ \\
ano-genital & DPN 1 & $0,16 \pm 0,007$ & $0,16 \pm 0,007$ & $0,17 \pm 0,003$ & $0,18 \pm 0,006$ \\
(cm) & DPN 21 & $0,77 \pm 0,015$ & $0,79 \pm 0,021$ & $0,77 \pm 0,016$ & $0,74 \pm 0,013$ \\
\hline
\end{tabular}

Dados expressos em média \pm E.P.M. CC (controle-controle): $\mathrm{n}=8$; CHF (controle-hiperlipídica): $\mathrm{n}=8$; HFC (hiperlipídica-controle): $\mathrm{n}=8$; HFHF (hiperlipídica-hiperlipídica): $\mathrm{n}=10$. ANOVA de duas vias. Efeito de tempo significante para os três parâmetros, $p<0,0001$. Efeito de interação tempo $x$ grupo significante nos parâmetros de peso corporal e distância ano-genital, $p<0,05$. Efeito de grupo significante para o comprimento corporal, $p<0,05$. ${ }^{*} p<0,05$ comparado aos grupos CC e HFC.

Foi observado o dia de descolamento das orelhas, de aparecimento de pelos, do surgimento dos dentes incisivos e abertura dos olhos na geração $F_{2}$. Com exceção da abertura do conduto auditivo, que apresentou uma tendência à diferença entre os grupos experimentais $(p=0,0833 ; F(3,30)=2,44)$, não houve alterações significantes nesses parâmetros ( $p>0,05$ - Figura 49).

Figura 49 - Parâmetros de desenvolvimento físico dos filhotes na geração $F_{2}$.

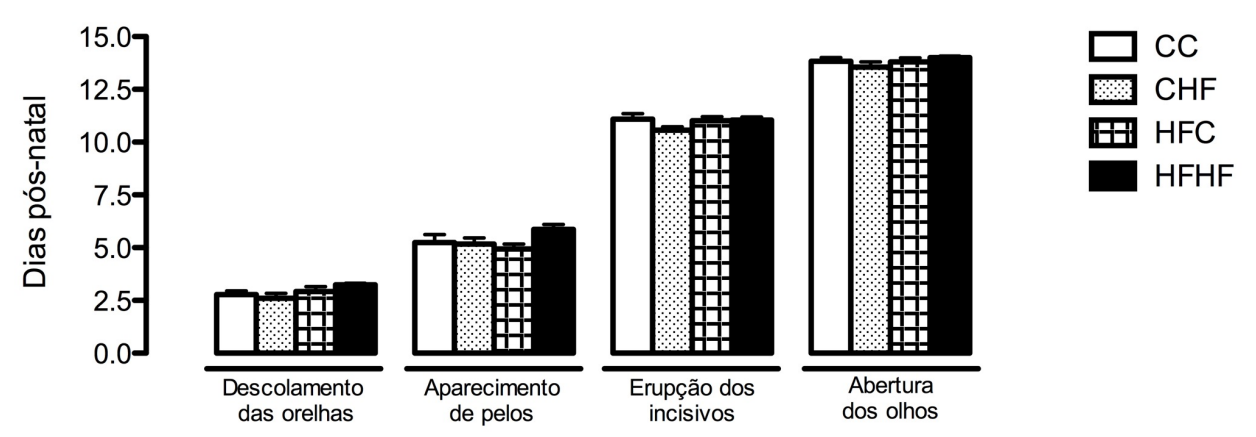

Os dados são expressos em média \pm E.P.M. CC (controle-controle): $\mathrm{n}=8$; CHF (controlehiperlipídica): $\mathrm{n}=8$; HFC (hiperlipídica-controle): $\mathrm{n}=8$; HFHF (hiperlipídica-hiperlipídica): $\mathrm{n}=10$. ANOVA de uma via. 


\subsection{Análises nos machos da geração $F_{1}$ após o DPN 70}

Após o acompanhamento da ingestão alimentar e do peso dos animais do DPN21 ao 70, foram realizados testes para análise dos níveis de ansiedade e do desempenho sexual dos machos.

A figura 50 mostra os dados do teste de labirinto em cruz elevado. Não houve diferenças estatisticamente significantes nos parâmetros analisados $(p>0,05)$.

No teste de comportamento sexual (Figura 51), um macho do grupo CC e um do grupo CHF eram sexualmente inativos, não realizando montas e intromissões nas fêmeas, e portanto foram excluídos das análises. Dois animais do grupo CHF não chegaram a ejaculação, mas realizaram montas e intromissões nas fêmeas. Assim, esses animais foram excluídos das análises de latência para primeira ejaculação, latência para primeira intromissão após a ejaculação e número de intromissões pós ejaculação.

Figura 50 - Teste de labirinto em cruz elevado - Machos $F_{1}$.
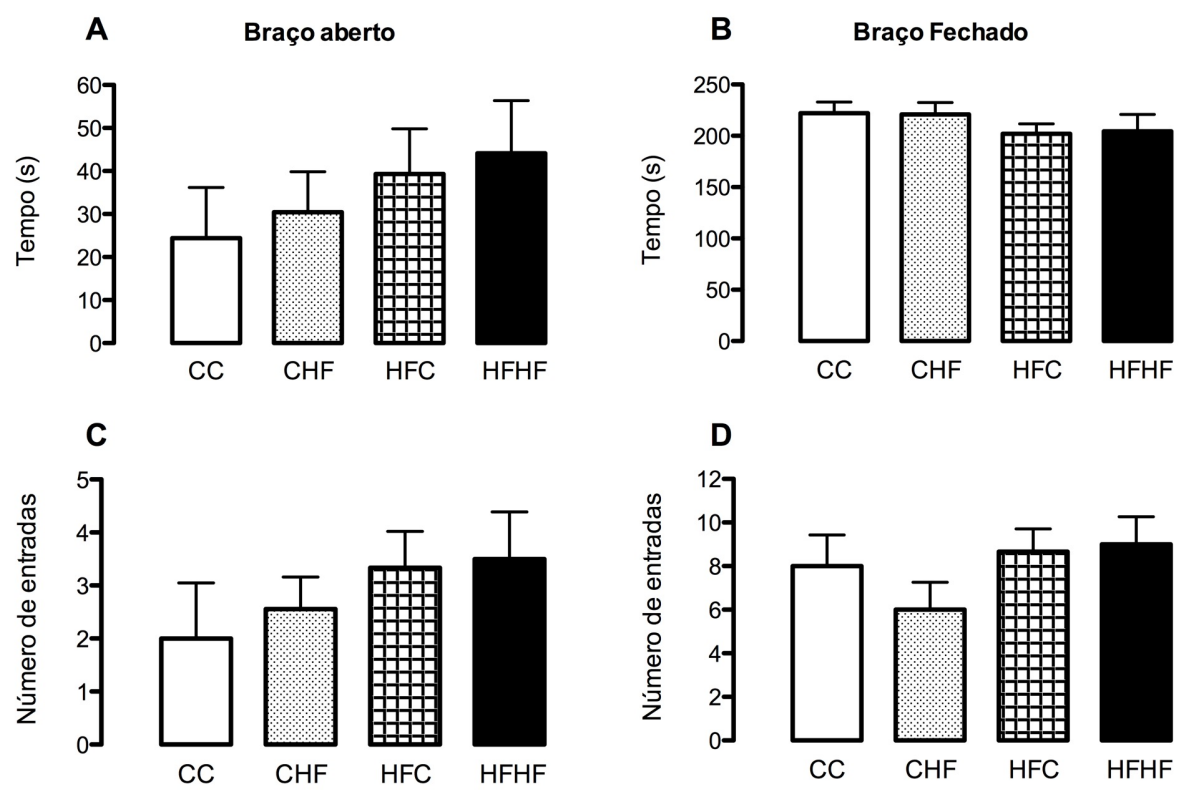

Os dados são apresentados em média \pm E.P.M. CC (controle-controle): $n=7$; CHF (controlehiperlipídica): $n=9$; HFC (hiperlipídica-controle): $n=9$; HFHF (hiperlipídica-hiperlipídica): $n=8$. A. Tempo no braço aberto. B. Tempo no braço fechado. C. Número de entradas no braço aberto. D. Número de entradas no braço fechado. ANOVA de uma via. 
Figura 51 - Parâmetros avaliados no teste de comportamento sexual de machos.

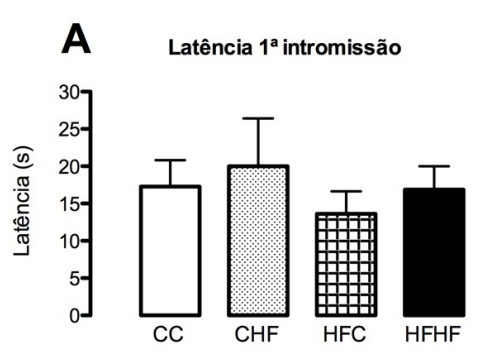

D

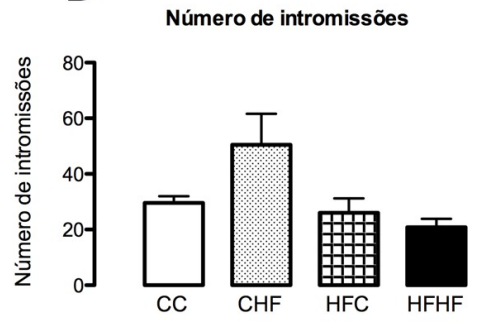

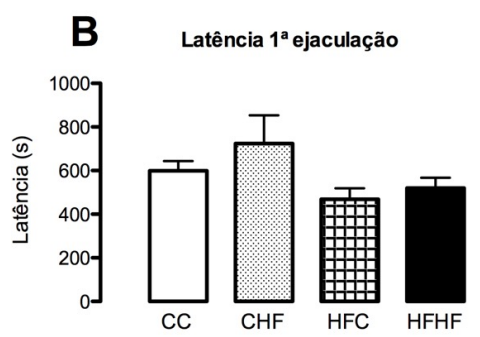

E

Número de ejaculações

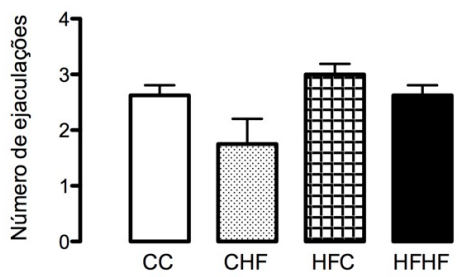

C Latência 1' 1'intromissāo pósejejculą̧ăo

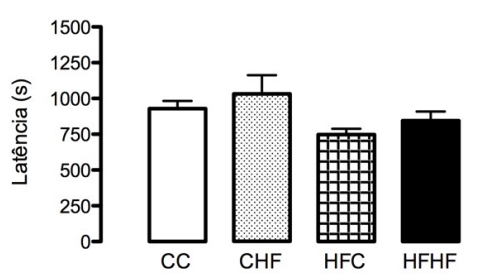

$\mathbf{F}$ Número de intromissões pós-ejaculação

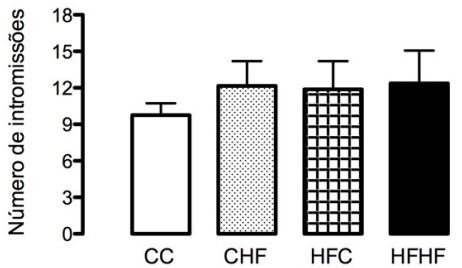

Os dados são expressos em média \pm E.P.M. CC (controle-controle): $n=8 ; \mathrm{CHF}$ (controlehiperlipídica): $\mathrm{n}=6$; HFC (hiperlipídica-controle): $\mathrm{n}=8$; HFHF (hiperlipídica-hiperlipídica): $\mathrm{n}=8$. A. Latência para primeira intromissão. B. Latência para $1^{\text {a }}$ ejaculação. C. Latência para primeira intromissão após a ejaculação. D. Número de intromissões antes da $1^{a}$ ejaculação. E. Número total de ejaculações durante o teste. F. Número de intromissões após a primeira ejaculação. ANOVA de uma via. Para os dados dos parâmetros $\mathrm{D}$ e $\mathrm{E}$, o teste de variância amostral mostrou-se significante sendo, portanto, utilizado o teste de Kruskal-Wallis.

Não houve diferenças significantes na latência para primeira intromissão (Figura 51A) e no número de intromissões após a ejaculação (Figura 51F - p>0,05). Porém, em todos os demais parâmetros avaliados houve uma tendência a diferença entre os grupos (latência primeira ejaculação: $p=0,0856$; latência primeira intromissão após a ejaculação: $p=0,0672$; número de intromissões: $p=0,0779$ e número de ejaculações: $p=0.0878$ ).

Após a realização dos testes comportamentais, aos 120 dias de vida aproximadamente, os animais foram pesados e sofreram eutanásia. O peso dos depósitos de gordura retroperitoneal e perigonadal e o índice de gordura corporal podem ser observados na figura 52 .

O peso corporal dos machos não apresentou diferença entre os grupos. Entretanto, os animais HFHF possuem maior depósito de gordura retroperitoneal comparado aos grupos CC e HFC $(p=0,0012 ; F(3,34)=6,644)$. Esses mesmos animais também apresentaram maior acúmulo de gordura perigonadal quando comparados ao grupo controle $(p=0,0049 ; F(3,31)=9,158)$. Assim, os machos do grupo HFHF possuem um maior percentual de gordura corporal que os grupos $\mathrm{CC} e$ 
HFC, e o mesmo acontece com o grupo CHF em relação ao controle $(p=0,0009 ; K=$ $16,60)$.

O peso do fígado, dos órgãos do aparelho reprodutor (testículo, epidídimo, próstata e vesícula seminal cheia e vazia) e da hipófise não apresentaram diferenças estatísticas entres os grupos experimentais (Tabela 14).

Figura 52 - Peso corporal, do tecido adiposo e percentual de gordura corporal nos machos $F_{1}$.
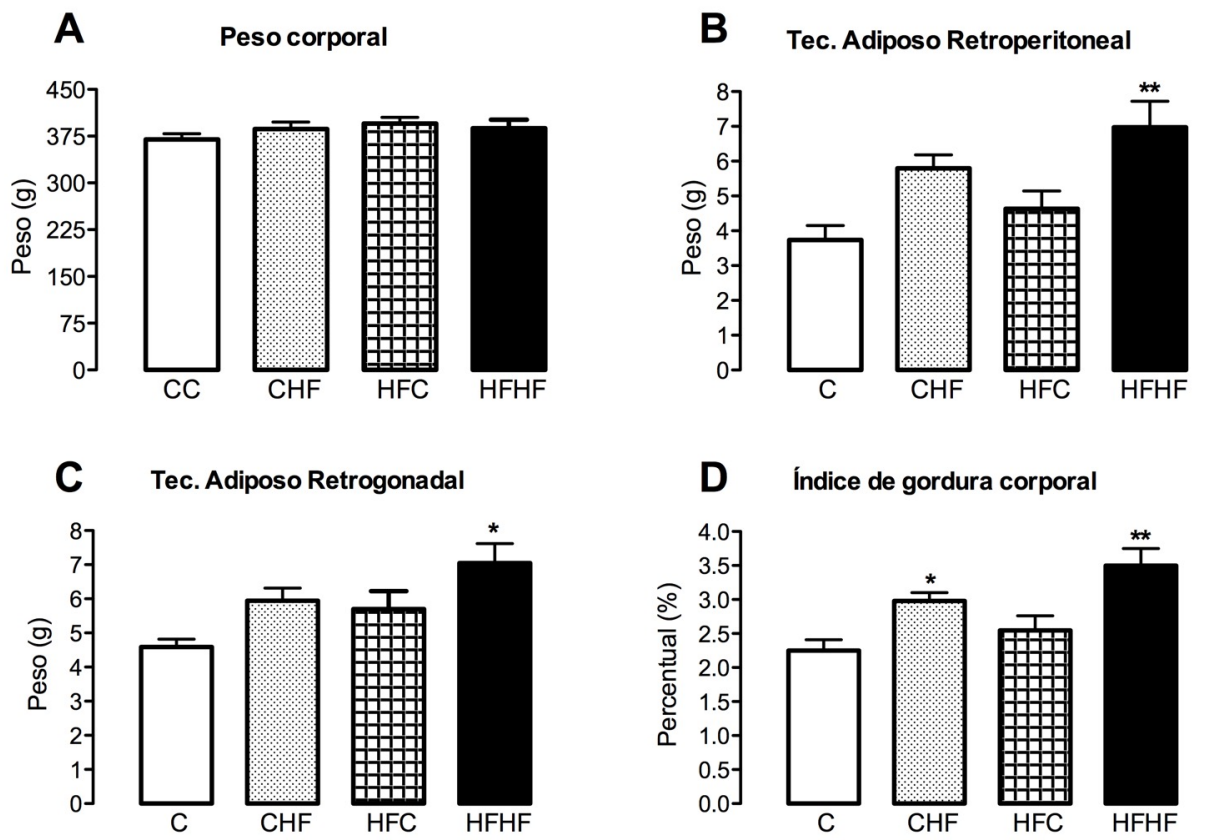

Os dados são expressos em média \pm E.P.M. CC (controle-controle): $n=9$; CHF (controlehiperlipídica): $\mathrm{n}=9$; HFC (hiperlipídica-controle): $\mathrm{n}=10$; HFHF (hiperlipídica-hiperlipídica): $\mathrm{n}=10$. ANOVA de uma via seguido pelo teste de Tukey. A. Peso corporal absoluto. B. Peso do tecido retroperitoneal, $p<0,01$.C. Peso em gramas do tecido adjacente às gônadas, $p<0,01$. D. Percentual de gordura corporal, $p<0,001$. ${ }^{*} p<0,05$ comparado ao grupo controle (CC). * $p<0,05$ em relação aos grupos CC e HFC.

Foram dosados os níveis séricos de colesterol total, HDL-colesterol, triglicérides, AST e ALT nos machos, não sendo observado nenhuma diferença estatisticamente significante ( $p>0,05$ - Tabela 15). 
Tabela 14 - Peso do fígado, órgãos do sistema reprodutor e da hipófise - machos.

\begin{tabular}{ccccc}
\hline \multirow{2}{*}{ Parâmetros } & \multicolumn{4}{c}{ Grupos } \\
\cline { 2 - 5 } & CC & CHF & HFC & HFHF \\
\hline Fígado (g) & $10,47 \pm 0,7$ & $10,79 \pm 0,4$ & $12,28 \pm 0,65$ & $11,61 \pm 1,02$ \\
Testículo (g) & $1,83 \pm 0,05$ & $1,75 \pm 0,03$ & $1,75 \pm 0,04$ & $1,81 \pm 0,04$ \\
Epidídimo (g) & $0,59 \pm 0,01$ & $0,56 \pm 0,01$ & $0,62 \pm 0,02$ & $0,58 \pm 0,01$ \\
Próstata (g) & $0,44 \pm 0,04$ & $0,41 \pm 0,02$ & $0,43 \pm 0,04$ & $0,41 \pm 0,02$ \\
Vesícula cheia (g) & $0,67 \pm 0,04$ & $0,66 \pm 0,04$ & $0,72 \pm 0,04$ & $0,65 \pm 0,05$ \\
Vesícula vazia (g) & $0,23 \pm 0,04$ & $0,21 \pm 0,02$ & $0,26 \pm 0,01$ & $0,26 \pm 0,03$ \\
Hipófise (g) & $0,024 \pm 0,012$ & $0,017 \pm 0,005$ & $0,028 \pm 0,009$ & $0,018 \pm 0,009$
\end{tabular}

Os dados são expressos em média \pm E.P.M. CC (controle-controle): $n=9$; CHF (controlehiperlipídica): $n=9$; HFC (hiperlipídica-controle): $n=10$; HFHF (hiperlipídica-hiperlipídica): $n=10$. ANOVA de uma via. Para o dados de peso do epidídimo e da vesícula vazia, o teste de variância amostral mostrou-se significante sendo, portanto, utilizado o teste de Kruskal-Wallis.

Tabela 15 - Parâmetros bioquímicos dos machos no DPN120.

\begin{tabular}{|c|c|c|c|c|}
\hline \multirow{2}{*}{ Parâmetros } & \multicolumn{4}{|c|}{ Grupos } \\
\hline & $C C$ & $\mathrm{CHF}$ & HFC & HFHF \\
\hline Colesterol (mg/dL) & $45,8 \pm 2,6$ & $43,2 \pm 1,4$ & $41,5 \pm 1,0$ & $39,8 \pm 1,6$ \\
\hline $\begin{array}{l}\text { HDL-colesterol } \\
\text { (mg/dL) }\end{array}$ & $13,7 \pm 1,1$ & $13,7 \pm 1,6$ & $16,2 \pm 2,0$ & $16,1 \pm 2,1$ \\
\hline $\begin{array}{l}\text { Triglicérides } \\
\text { (md/dL) }\end{array}$ & $102,7 \pm 10,9$ & $101,6 \pm 10,8$ & $127,1 \pm 14,5$ & $127,2 \pm 8,7$ \\
\hline AST (U/L) & $84,9 \pm 8,9$ & $122,2 \pm 19,6$ & $98,0 \pm 13,2$ & $91,0 \pm 16,3$ \\
\hline ALT (U/L) & $283,8 \pm 83,5$ & $180,2 \pm 54,1$ & $190,7 \pm 42,6$ & $308,4 \pm 59,3$ \\
\hline
\end{tabular}

\subsection{Análise da expressão gênica hipotalâmica durante a gestação}

A seguir são mostrados os dados de avaliação da expressão por qPCR de genes envolvidos com o desenvolvimento e ingestão alimentar no hipotálamo durante a gestação. Foram avaliados o cérebro de animais nos dias gestacionais 12, 14, 16 e 18. É importante mencionar que todas as amostras de RNA extraídas dos fetos foram inicialmente testadas para avaliar sua integridade, antes da realização das medidas de expressão gênica apresentadas abaixo. 
A figura 53 apresenta os dados de expressão dos genes relacionados ao desenvolvimento do hipotálamos durante a gestação. Não houve diferenças significantes para o Ngn3, Mash1 e Six3. O Rax apresentou um efeito de tempo significante $(p=0,044 ; F(3,55)=2,874)$, não havendo diferença entre os grupos.

Figura 53 - Expressão de genes que atuam no desenvolvimento hipotalâmico durante a gestação.

A

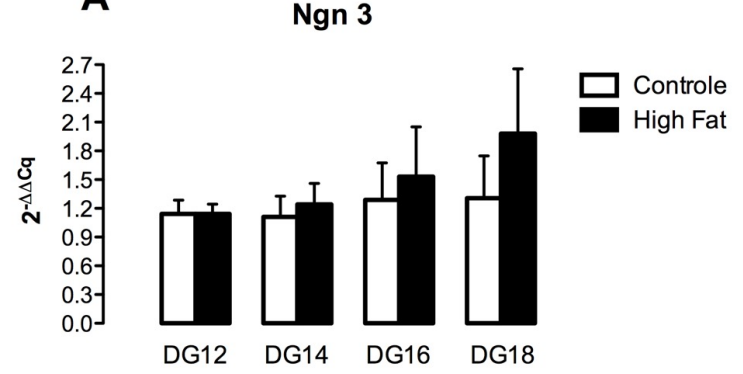

C

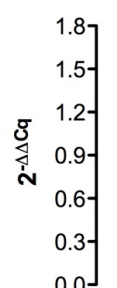

$\operatorname{Rax}$

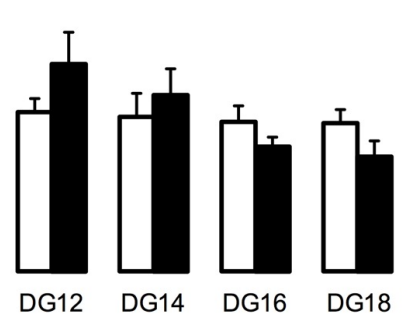

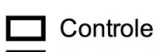

High Fat
B

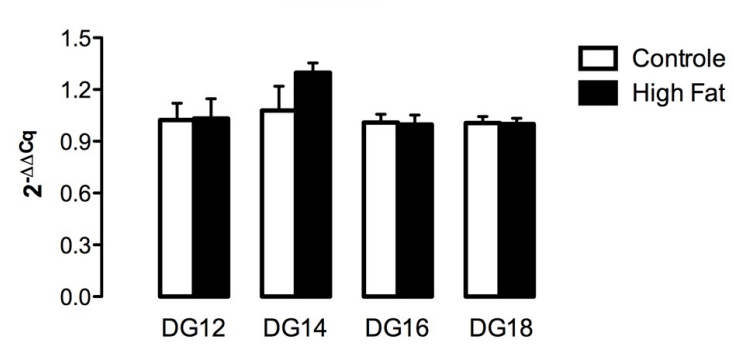

D

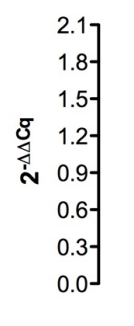

Six3

Os dados são expressos em média \pm E.P.M. Controle, $n=8$ (2 fetos por mãe), Hiperlipídica, $n=8(2$ fetos por mãe). ANOVA de duas vias. A. Neurogenina 3. B. Mammalian achaete scute homolog-1. C. Retinal and anterior neural fold homeobox. Efeito de tempo significante para Rax, $p<0,05$. D. SIX homeobox 3 .

Também foram analisados os genes que estão envolvidos com o controle da ingestão alimentar, como o POMC, NPY e o AgRP (Figura 54). Houve efeito significante de tempo $(p<0,01 ; F(3,55)=4.273)$ e da interação tempo $x$ dieta $(p=0,015 ; F(3,55)=3,806$ para o POMC. Houve também efeito de grupo significante $(p=0,02, F(1,14)=5,543)$, sendo que o no $D G 18$, a expressão do POMC no grupo com dieta hiperlipídica era maior em relação ao controle neste dia. $O$ mesmo ocorreu com o NPY. Também houve efeito significante de tempo e $(p<0,001 ; F(3,55)$ $=9,960)$ da interação tempo $\times$ grupo para a expressão do NPY $(p=0,0424 ; F(3,55)=$ 2,913). Não houve diferenças estatísticas para e expressão do gene que codifica $\operatorname{AgRP}(p>0,05)$. 
Figura 54 - Expressão dos genes envolvidos com o controle da ingestão alimentar.
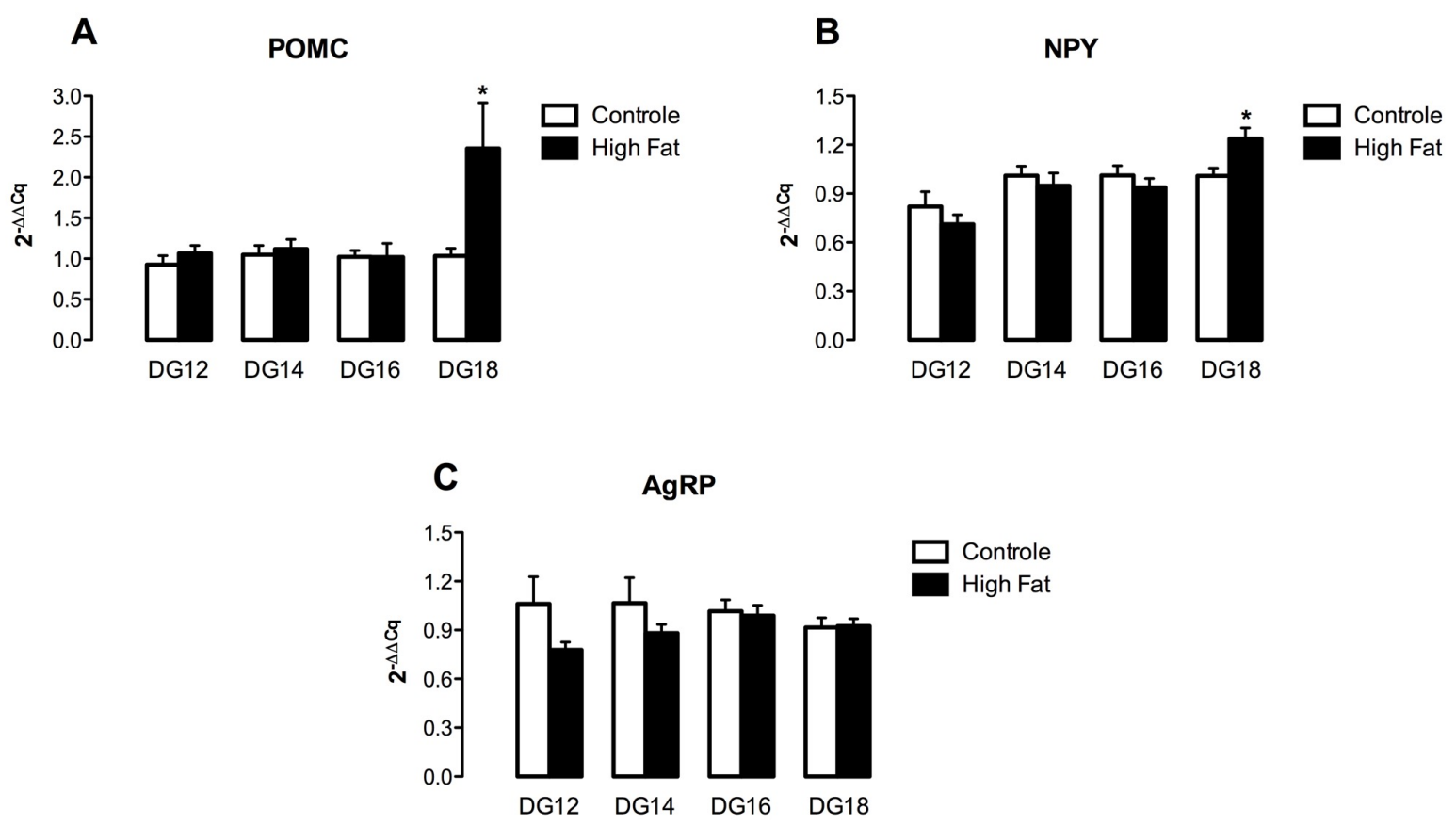

Os dados são expressos em média \pm E.P.M. Controle, $\mathrm{n}=8$ (2 fetos por mãe), Hiperlipídica, $\mathrm{n}=8$ (2 fetos por mãe). ANOVA de duas vias. A. Pro-opiomelanocortina. Efeito de tempo significante, $p<0,01$. Efeito da interação tempo $x$ grupo significante, $p<0,05$. Efeito da dieta significante, $p<0,05$. ${ }^{*} p<0,001$ comparado ao grupo controle no DG18, pós-teste de Bonferroni. B. Neuropeptídeo Y. Efeito de tempo significante, $p<0,001$. Efeito da interação tempo $x$ grupo significante, $p<0,05$. ${ }^{*} p<0,05$ comparado ao grupo controle, teste T de Student. C. Agouti-related peptide (AgRP).

Por último, foram analisados genes que estão envolvidos na transcrição de proteínas que são importantes na regulação da ação de peptídeos envolvidos com o controle da ingestão alimentar, como a PC1, PC2, SOCS3 e MC4R (Figura 55).

PC1 e PC2 não apresentaram diferenças significantes entre os grupos controle e com dieta hiperlipídica materna. Entretanto, SOCS3 mostrou um efeito de tempo e da interação tempo x grupo significante $(p=0,0158 ; F(3,53)=3,771$ e $p<0,001 ; F(3,53)=6,305$ respectivamente). Ademais, no DG12 houve um aumento da expressão desse gene no grupo High Fat comparado ao controle.

A expressão do gene do MC4R apresentou efeito do tempo significante nos dias analisados da gestação $(p=0,0014 ; F(3,52)=6,00)$. O efeito da interação tempo $x$ grupo também mostrou-se significante $(p=0,0250 ; F(3,52)=3,379)$, indicando que os animais de cada grupo responderam diferentemente entre si ao longo do período. 
Figura 55 - Expressão gênica do $P C 1, P C 2$, SOCS3 e MC4R.
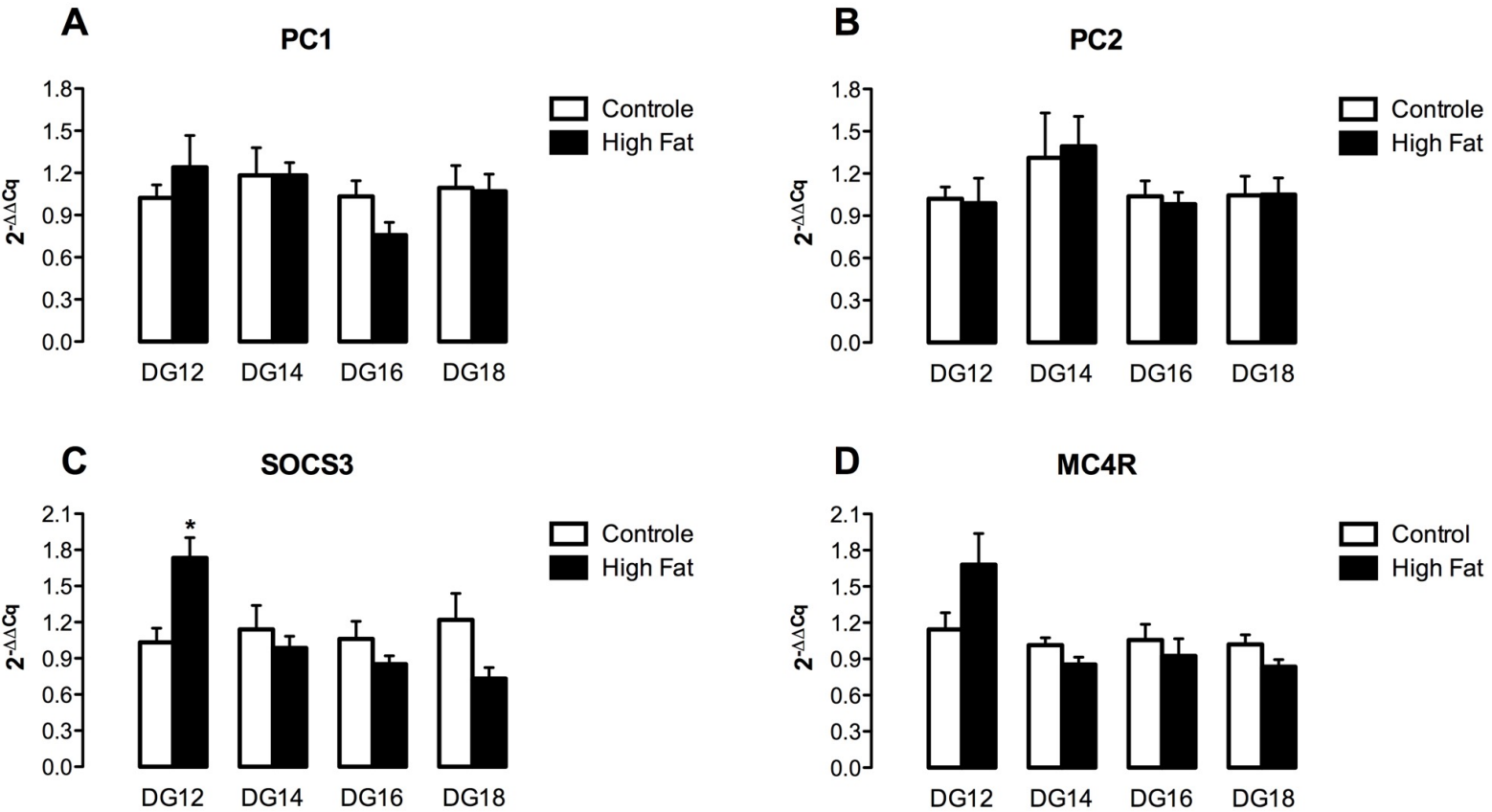

Os dados são expressos em média \pm E.P.M. Controle, $n=8$ (2 fetos por mãe), Hiperlipídica, $n=8$ (2 fetos por mãe). ANOVA de duas vias. A. Pro-proteína convertase 1 (PC1). B. Pro-proteína convertase 2 (PC2). C. Suppressor of cytokine signaling (SOCS3). 3. Efeito de tempo significante, $p<0,05$. Efeito da interação tempo $x$ grupo significante, $p<0,001 .{ }^{*} p<0,01$ comparado ao controle no DG12, teste $T$ de Student. D. Receptor de melanocortina-4 (MC4R). Efeito de tempo significante, $p<0,001$. Efeito da interação tempo $x$ grupo significante, $p<0,05$.

Figura 56 - Neurônios POMC no núcleo arqueado do hipotálamo no DG18.
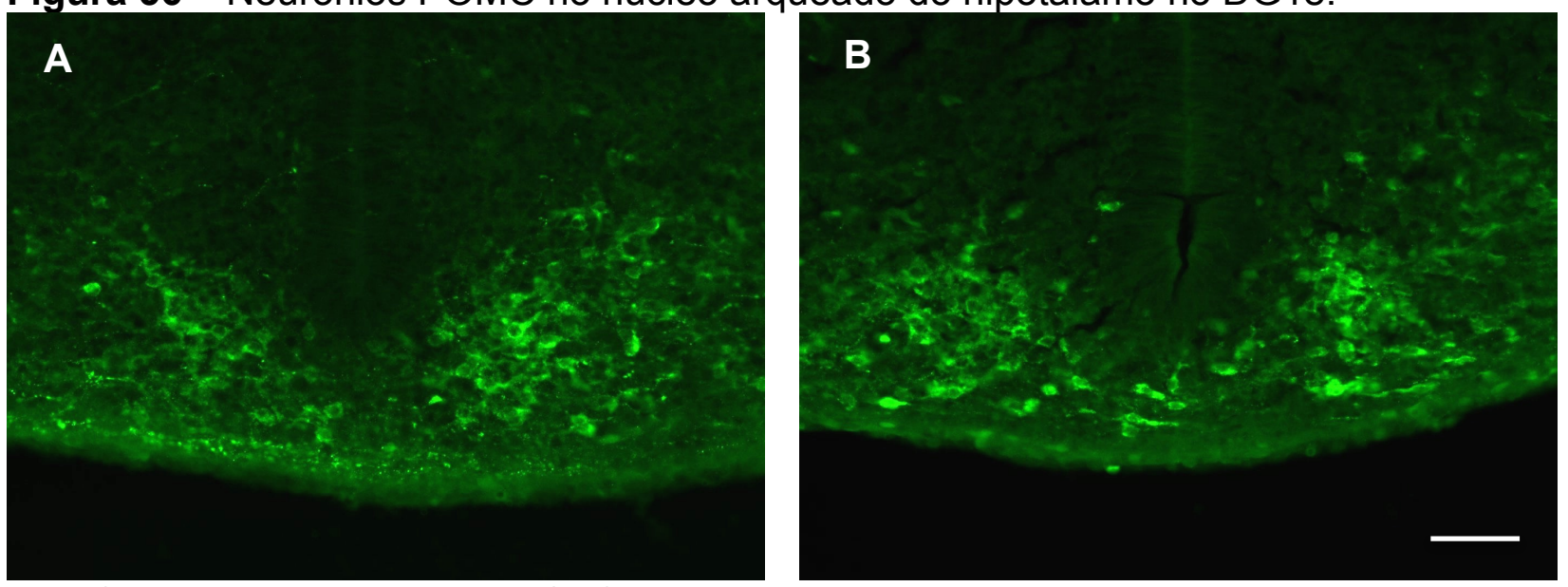

Imunofluorescência dos neurônios POMC no núcleo arqueado de animal controle (A) e de animal que a mãe consumiu dieta hiperlipídica durante a gestação (B). Nota-se a maior quantidade de neurônios marcados na figura $\mathrm{B}$, indicando que há uma maior expressão de proopiomelanocortina nesse grupo. Escala: $500 \mu \mathrm{m}$.

Além da expressão gênica, também foi avaliada a presença de neurônios imunorreativos ao POMC no DG18 em ambos os grupos (Figura 56). Os fetos de mães que ingeriram dieta hiperlipídica parecem apresentar maior número de neurônios marcados, o que indica que além da maior expressão gênica para POMC, 
a proteína também está sendo codificada em maior número quando comparado ao controle. 
"Por vezes sentimos que aquilo que fazemos não é senão uma gota de água no mar. Mas o mar seria menor se lhe faltasse uma gota." Madre Teresa de Calcutá

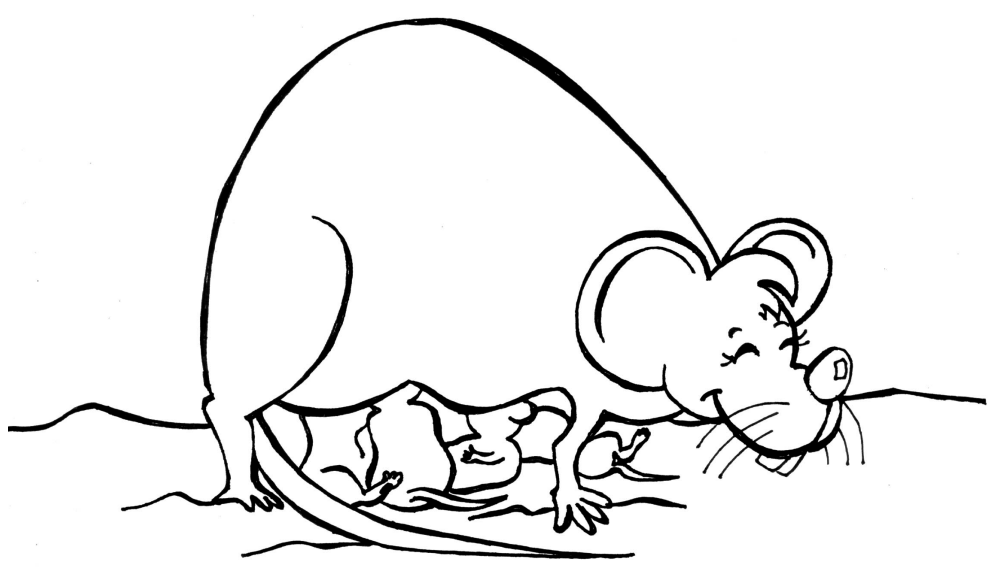


O presente estudo analisou a influência do consumo de dieta rica em lipídeos pela mãe sobre o comportamento maternal e o desenvolvimento dos filhotes ao longo da vida, em relação à aspectos metabólicos, comportamentais e físicos. $\mathrm{Na}$ vida adulta, as descentes fêmeas foram acasaladas e as alterações promovidas pela dieta durante a gestação e lactação dessas mães (Geração $F_{1}$ ), também foram avaliadas. Os resultados obtidos confirmam a importância da nutrição materna sobre a mãe e a vida de seus filhotes.

As mães $F_{0}$ passaram a ingerir a ração com $45 \%$ de gordura no dia em que foi constatada a prenhez (DG0). Durante a gestação, possivelmente pelo pouco tempo em que estavam expostas a dieta hiperlipídica, não houve diferenças no peso desses animais. Mães com dieta composta por $60 \%$ de lipídeos também não apresentaram peso elevado durante a gestação (Purcell et al., 2011). Entretanto, ao contrário do que se poderia esperar, o consumo da dieta rica em lipídeos fez com que as mães tivessem um peso reduzido em relação ao controle durante a lactação.

Como descrito anteriormente, a composição da fração lipídica da dieta, além da pequena porção de banha animal (gordura saturada), contém também óleos vegetais (de soja, principalmente), ricos em ácidos graxos insaturados. Em um estudo em que foram comparados diferentes tipos de dieta hiperlipídica, animais que consumiram ração com o extrato etéreo rico em ácidos graxos insaturados, oriundos de óleo de linhaça ou de azeite de oliva, não apresentaram diferenças no peso em relação aos controles (Cintra et al., 2012). Ademais, nos casos em que a porção lipídica na dieta era exclusivamente composta por esses tipos de gorduras, alguns animais mostraram redução peso corporal (Cintra et al., 2012). Portanto, isso correlaciona-se com o fato de os animais analisados no presente estudo não apresentarem um aumento significativo no peso corporal, ou até mesmo obesidade, como seria esperado com a ingestão de uma dieta rica em lipídeos. Os filhotes da geração $F_{1}$ não apresentaram diferenças no peso entre os grupos no início da vida adulta, sendo que ao se tornarem mães dos grupos CHF e HFHF elas eram significativamente mais leves na gestação e durante toda a lactação. Ratas obesas antes da gestação também apresentam um ganho de peso reduzido durante a prenhez (Panchenko et al., 2016). Nesse caso, além da composição da dieta, o estado fisiológico em que se encontravam as fêmeas pode ter interferido. Ratas alimentadas com dieta rica em lipídeos durante a gestação e lactação, com composição semelhante à utilizada neste estudo, apresentaram peso semelhante às 
fêmeas controles durante esse período. Porém, ratas virgens utilizando a mesma dieta apresentaram maior peso e adiposidade corporais que ratas virgens controles (Guo, Jen, 1995).

A lactação é o período da vida em que as necessidades energéticas da mãe são maiores que em qualquer outro. Em pequenos roedores, os filhotes em desenvolvimento são completamente dependentes de suas mães para alimentar-se nas duas primeiras semanas de vida, e durante esta fase, a ninhada pode crescer a um peso que excede o peso da própria mãe (Woodside et al., 2008). Além disso, sabe-se que a reprodução faz com que os estoques de gordura sejam recrutados para suprir as demandas metabólicas (Hansen et al., 2013), tendo a leptina e outros peptídeos relacionados à ingestão alimentar e controle energético, como NPY, POMC, e AgRP, alta influência sobre a fertilidade (Celik et al., 2015). Durante a gestação, nos dois primeiros trimestres o corpo materno acumula gordura, porém nos últimos estágios da mesma a atividade do tecido adiposo aumenta, estabelecendo uma condição de catabolismo, que permanece durante a lactação (Herrera et al., 2006). Assim, como a dieta utilizada não favorece o acúmulo de gordura (Wang et al., 1999), sendo o tecido adiposo a principal fonte de armazenamento energético (Carmen, Victor, 2006; Viscarra, Ortiz, 2013), combinado às alterações metabólicas durante a gestação e lactação, as mães HF, CHF e HFHF apresentaram menor aumento de peso durante esse período. A reduzida quantidade de tecido adiposo retroperitoneal e retrogonadal, principalmente nas mães $F_{0}$, também corrobora esta hipótese. Além disso, o consumo calórico desses animais, com exceção da gestação das mães $F_{0}$, não foi maior do que nos controles, o que também não favorece o aumento de peso.

É importante ressaltar que o menor ganho de peso durante a gestação apresentado por essas mães não foi devido a um menor número de filhotes nem a um peso reduzido dos mesmos ao nascer, uma vez que não havia diferenças significantes de peso, de tamanho da ninhada e da duração da gestação entre os grupos nos neonatos no DPN1. Connor et al., (2012) também não encontraram diferenças nesses parâmetros em ratas alimentadas com dieta com $45 \%$ das calorias oriundas de lipídeos. Purcell et al., (2011) também não encontraram diferenças no número de filhotes, na proporção de machos e fêmeas nascidos em cada ninhada e no peso ao nascimento de filhotes oriundos de mães em dieta com $60 \%$ de lipídeos. Entretanto, Buonfiglio et al., (2016) observaram uma menor taxa de 
sobrevivência dos filhotes em mães alimentadas com dieta rica em gordura. Tem sido relatado que essas mães apresentam alterações no ciclo estral e na fertilidade (Bermejo-Alvarez et al., 2012; Connor et al., 2012), porém isso não ocorreu nesse estudo.

As mães da geração $F_{0}$ apresentaram maior consumo calórico nos terços iniciais da gestação, e este consumo gradualmente foi assemelhando-se ao do grupo controle. Isso poder estar relacionado com o fato de que a gordura estar associada à saciedade e sinais homeostáticos (Horn et al., 1996; Schwarts et al., 2008). As mães da geração $F_{1}$, como já estavam habituadas à maior quantidade de lipídeos na ração desde o início da vida, mantiveram seu consumo semelhante ao dos animais com ração padrão, consumindo apenas o necessário para suas necessidades energéticas durante a gestação e lactação. Trottier et al., (1998) também não encontraram diferenças no consumo calórico de mães alimentadas com dieta hiperlipídica. Ainda, animais alimentados com uma dieta rica em lipídeos insaturados não apresentam diferenças no consumo diário em relação à animais com dieta padrão (Cintra et al., 2012; Oliveira et al., 2015).

Não houve alterações no teste de tolerância a insulina neste estudo. A prenhez é um estado fisiológico de alta demanda energética e que demanda múltiplas adaptações no organismo feminino. Uma dessas mudanças é a alteração na secreção de insulina e na sensibilidade a ela nos tecidos periféricos. Durante a gestação, os tecidos periféricos da mãe se tornam resistentes à insulina para garantir a demanda de glicose para os fetos (Aerts, Van-Assche, 2006). Desta forma, alterações metabólicas drásticas seriam necessárias para interferirem no teste de tolerância à insulina durante esta fase. Além disso, a dieta rica em lipídeos insaturados não parece ser capaz de induzir mudanças na sensibilidade à insulina (Cintra et al., 2012; Oliveira et al., 2015). A queda nos níveis glicêmicos durante a prenhez deve-se a maior necessidade de glicose requerida pelos fetos no terço final da gestação (Thornburg et al., 2006). Strakovsky et al., (2011) também não encontraram alterações na glicemia plasmática de ratas submetidas à dieta com alto teor de gordura durante a prenhez.

Apesar de a ingestão de ração rica em lipídeos não produzir alterações no ganho de peso durante a gestação nas mães da geração $F_{0}$, possivelmente pelo pouco tempo a que estavam expostas à nova dieta, alterações metabólicas puderam ser observadas, uma vez que a área sob a curva do teste de tolerância a glicose 
(AUC) foi maior nos animais que consumiram alto teor de gordura. Como dito anteriormente, uma fêmea passa por profundas transformações metabólicas e comportamentais para preparar-se para o período de lactação, que demanda cuidados específicos com a prole e grande aporte energético (Lambert, 2012; Woodside et al., 2012). Estas mudanças iniciam-se durante a gestação, e o consumo de dieta rica em gordura parece ter prejudicado os ajustes metabólicos necessários, o que resultou no aumento da AUC do grupo com alimentação hiperlipídica. A persistência da dieta rica em lipídeos durante a lactação, fez com que as mães $F_{0}$ se tornassem intolerantes à glicose. Curiosamente, as mães da geração $F_{1}$ não apresentaram diferenças entre si nos testes de controle glicêmico realizados, o que pode ter ocorrido devido ao longo período de ingestão da dieta, tendo o organismo se adaptado aos nutrientes recebidos na alimentação. Entretanto, há evidências de que o consumo de dieta hiperlipídica durante a gestação e lactação promove o aumento dos níveis de glicose nos filhotes do nascimento até o desmame (Strakovsky et al., 2011; Yang et al., 2012). O número de estudos na literatura que investigam o efeito do consumo de dietas deste tipo pelas mães sobre a programação e controle glicêmico dos descendentes é grande, entretanto, inconsistências entre esses estudos limitam a capacidade de identificar mecanismos comuns para a origem ou não de possíveis alterações nos filhotes (Ainge et al., 2011).

Neste trabalho, a ingestão de dieta rica em lipídeos pela mãe $\left(F_{0}\right)$ não interferiu no ganho de peso da ninhada, apesar de haver uma interação entre os fatores tempo e dieta. Os parâmetros de desenvolvimento físico e sexual e o aumento de peso individual de machos e fêmeas não sofreram alterações durante a lactação. Corroborando nossos dados, Trottier et al., (1998) também não encontraram diferenças no crescimento das ninhadas durante a lactação em mães alimentadas com uma dieta com $20 \%$ de lipídeos. Na geração $F_{2}$, os filhotes HFHF apresentaram uma tendência ao atraso na abertura do conduto auditivo. Um estudo utilizando dieta com $52 \%$ de lipídeos mostrou que os filhotes apresentaram atraso na abertura do conduto auditivo, na erupção dos incisivos inferiores e na abertura dos olhos e tiveram redução do peso e comprimento corporais neste período (Giriko et al., 2013).

No que diz respeito aos filhotes da geração $F_{1}$ após o desmame, no DPN35, os machos que sempre receberam dieta rica em lipídeos desde sua concepção 
(HFHF) apresentaram menor peso corporal neste período peripuberal. Interessantemente, um estudo mostrou que o ganho de peso dos 30 aos 35 dias de vida de ratos machos alimentados com dieta hiperlipídica é um fator capaz de determinar se este animal é mais propenso a desenvolver obesidade na vida adulta. Os animais que tem maior ganho de peso nessa fase, mesmo apresentando peso e ingesta alimentar regulares, possuem alterações metabólicas e neuronais similares a de animais adultos obesos (Leibowitz et al., 2007). Os machos com dieta hiperlipídica nesse estudo, aos 70 dias de vida possuíam peso e adiposidade semelhante aos grupos alimentados com dieta padrão, porém houve uma interação dos efeitos do tempo e da dieta apenas nesse sexo. É necessário ressaltar aqui a importância de se ponderar a generalização de resultados encontrados em apenas um gênero de animais testados, principalmente no que envolve achados metabólicos e comportamentais, uma vez que machos e fêmeas podem apresentar respostas divergentes sob uma mesma situação. A interação encontrada nesta fase nos machos, resultou em uma maior quantidade de gordura corporal nos ratos HFHF no DPN120. Os resultados em relação aos machos em idade adulta avançada serão melhor discutidos na seção 5.4 .

Em relação às fêmeas no DPN35, CHF e HFHF apresentaram peso reduzido em relação aos grupos com ração controle após o desmame. Em um estudo conduzido por Sánchez-Garrido et al., (2013), fêmeas alimentadas com uma dieta com $45 \%$ de lipídeos após o desmame apresentaram baixo peso no dia da abertura do canal vaginal. Isso demonstra uma diferença de sensibilidade à dieta entre machos e fêmeas, e também ao período de transição que passaram: do desmame para a alimentação exclusivamente sólida (Sánchez-Garrido et al., 2013). Entretanto, machos e fêmeas ao atingirem o início da vida adulta (DPN70), não apresentavam mais essas diferenças em seu peso corporal. Também não houve diferenças em relação à quantidade de tecido adiposo e ao peso do fígado, mostrando que os animais se adaptaram às condições energéticas a que foram submetidos.

Outro fator que agrega ao fato de os animais terem se adaptado à dieta ao longo da vida é que apenas durante o período peripuberal houve diferenças no consumo calórico entre os grupos, para machos e fêmeas, diferindo entre si. No caso dos machos, a ingesta do grupo que ingeriu dieta rica em lipídeos desde a sua concepção foi maior que todos os demais grupos na $5^{a}, 6^{a}$ e $7^{a}$ semanas de vida, sendo o grupo a apresentar menor peso que os demais, como descrito 
anteriormente. $\mathrm{Na} 6^{\mathrm{a}}$ semana, que coincide com o descolamento do prepúcio dos ratos, que ocorreu por volta do $43^{\circ}$ dia de vida, a diferença foi ainda maior entre os grupos experimentais. O HFHF foi quem ingeriu mais calorias, e o CHF teve uma ingesta menor que o HFHF mas maior que os grupos CC e HFC. Isso demonstra que a dieta materna durante a gestação e lactação é importante para determinar o desenvolvimento dos filhotes pós-desmame, exercendo uma programação metabólica. Ainda, reforça a hipótese de que há diferenças entre os sexos nessas características epigeneticamente transmitidas, pois em relação às fêmeas, ambos os grupos CHF e HFHF apresentaram consumo maior que os demais grupos nas semanas 5, 6 e 7, ou seja, no período peripuberal.

Neuropeptídeos reguladores da ingestão alimentar e do balanço energético, como o NPY, estão relacionados ao surgimento da puberdade (Minami et al., 1990; Sahu et al., 1992; Sutton et al., 1988), assim como a leptina (Bohlen et al., 2016; Cheung et al., 2001). O envolvimento de ácidos graxos essenciais, como o ácido linoleico e o ácido linolênico, também estão associados à instalação da puberdade (Smith et al., 1989). Naturalmente, a puberdade é uma fase em que o consumo de calorias, proteínas, ferro, zinco e outros nutrientes precisa ser aumentado para suprir o período crítico de rápido crescimento nos animais (Soliman et al., 2014). Isso de fato ocorreu com todos os animais deste estudo, porém nos grupos alimentados com dieta hiperlipídica, esse consumo foi consideravelmente maior. Portanto, durante a puberdade a dieta parece interferir diretamente na sinalização endógena de mecanismos homeostáticos de balanço enérgico, fazendo com que os animais consumam mais calorias para suprir suas demandas metabólicas, impedindo alterações temporais na instalação da puberdade. Esses mecanismos parecem sofrer variações de acordo com o sexo do animal e com a ingestão alimentar materna durante a prenhez e lactação.

\subsection{Comportamento materno}

As mães que receberam dieta hiperlipídica apresentaram prejuízos importantes na expressão dos cuidados maternos. Por definição, o comportamento materno refere-se a comportamentos apresentados durante os dias imediatamente antes e após o parto que são preparatórios para a chegada dos filhotes, ou que estão relacionados aos cuidados com a prole, como lamber, amamentar e carregar 
os filhotes e o aumento de agressividade materna. Mudanças nos níveis circulantes de estrógeno, progesterona e prolactina agem na área pré-optica medial no encéfalo para induzir a expressão desses comportamentos (Bridges 1994; Rosenblatt 1994). Normalmente, o comportamento maternal aparece durante o parto ou muito próximo a ele. Logo após, a fêmea exibe um grande interesse por sua prole (Numan et al., 2006). Variações nos cuidados da mãe para com o filhote podem afetar o desenvolvimento dos descendentes, promovendo alterações neuroendócrinas e comportamentais nos mesmos (Curley, Champagne, 2016; Kundakovic, Champagne, 2015).

No DPN 5, as mães $F_{1}$ gastaram mais tempo realizando o grooming dos filhotes. Nesta fase, os neonatos são altamente dependentes de sua mãe, dependendo dela os estímulos para defecar e urinar por meio do comportamento de lamber as áreas genitais dos neonatos (Numan, Insel, 2003). Além disso, em roedores, a estimulação dos genitais dos machos é necessária para ocorrer a masculinização do hipotálamo desses filhotes nos primeiros dias após o nascimento (Ugarte et al., 2011). No DPN 10, os filhotes já se movimentam sozinhos e necessitam de maior aporte energético por serem maiores. Portanto, há interferência direta do dia da lactação avaliado sobre alguns parâmetros, independente do grupo ou da geração a qual as mães pertencem. Por exemplo, as ratas passam mais tempo fora do ninho no DPN5, pois a mobilidade dos filhotes é pouca neste dia e eles não conseguem buscá-la com facilidade para iniciar a amamentação, e têm menor necessidade energética. Já no DPN10, além do contato físico com a mãe ser facilitado, os filhotes necessitam de mais nutrientes e energia todavia ainda não se alimentam de sólidos, o que faz com que as ratas permaneçam por um maior período em crouching e realizem o CMT. Ainda, o maior aporte energético requisitado no DPN10 pode explicar o fato de as mães $F_{1}$ terem realizado mais o grooming das mamas para estimulação da produção de leite.

Em relação à busca pelos filhotes, um parâmetro motivacional importante, as mães $F_{0}$ não apresentaram diferenças na latência para busca no $1^{\circ}, 5^{\circ}$ e $8^{\circ}$ filhotes. Porém, a variação entre a latência que a rata levou para buscar cada um desses filhotes no DPN5 e no DPN10 mostrou-se maior no grupo HF. Ou seja, no DPN10 as mães controles levaram menos tempo para buscar seus filhotes comparado ao DPN5. Já nas mães HF, esse tempo no DPN10 foi maior que no DPN5. Assim, hipoteticamente, as mães controle teriam melhor aprendido a buscar seus filhotes, 
sendo sensibilizadas e mais motivadas a isso no DPN10 do que as mães com dieta hiperlipídica. Portanto, a dieta parece afetar a memória comportamental das lactantes. Já foi demonstrado que no nos primeiros dias de lactação ocorrem alterações neurológicas nas ratas favorecendo a manutenção do comportamento maternal e consolidando a memória materna. Um curto período de experiência materna no período pós-parto faz com que a rata torne-se menos dependente de estímulos hormonais para exibir cuidados maternos, mesmo após longos períodos longe dos filhotes (Bridges, 1977, 1978). Consequentemente, a dieta rica em lipídeos pode ter influenciado as vias neuronais de sensibilização ao estímulo do neonato, tendo a área pré-optica medial como uma das principais regiões cerebrais regulamentadoras desse comportamento (Numan, Stolzenberg, 2009).

Outro tipo de análise dos cuidados maternos realizada tem como foco principal os componentes consumatórios do comportamento, onde há contato físico direto entre a mãe e o filhote, tendo esse a possibilidade de elicitar a execução de um determinado comportamento pela mãe (Terkel et al., 1979). Esse análise se dá sem intervenção prévia do experimentador e não há separação entre a mãe e os filhotes. Ainda, foram analisados os padrões de ejeção de leite nas ratas, sendo contabilizados pelo número de reflexos de ejeção de leite. Tais reflexos são caracterizados por um comportamento de alongamento do corpo dos filhotes (stretch response), seguido por troca do mamilo. Se não há liberação de leite, os animais não apresentam tal padrão de resposta, ao qual a rata reage elevando levemente seu corpo (Drewett et al., 1974; Jans, Woodside, 1987; Lincoln et al., 1973).

As fêmeas $F_{0}$ passaram mais tempo fora do ninho no DPN10, e neste dia, as mães $F_{1}$ deixaram o ninho mais vezes por menores períodos de tempo. $A$ demanda enérgetica da mãe é maior no DPN10 para suprir satisfatoriamente as necessidades energéticas dos filhotes, como dito anteriormente. Assim, é compreensível que ela fique um período maior longe dos filhotes e use esse tempo para alimentar-se e ingerir mais líquidos, por exemplo. Connor et al., (2012) observaram que ratas alimentadas com dieta hiperlipídica, desde o primeiro dia de gestação, lambem e realizam menos o grooming nos filhotes. Neste estudo não houve diferenças entre os grupos para esse parâmetro, porém, em conformidade com os resultados encontrados nas observações de 30 minutos, e com dados de Champagne et al., (2003), que afirmam que o pico de realização de grooming nos filhotes ocorre nos 
primeiros dias após o parto e diminui gradualmente ao longo da lactação, as mães gastaram menos tempo lambendo seus filhotes no DPN10.

Em relação aos parâmetros de ejeção de leite, em ambas as gerações o maior período em crouching não se mostrou diferente entre os grupos. Esse fato é relevante pois deixa claro que o menor número de ejeções apresentado pelos animais que ingeriram dieta hiperlipídica em algum momento da vida, não se deve ao fato de as mães desses grupos permanecerem por menos tempo sobre seus filhotes em posição de cifose. Outros fatores importantes são: as ratas da geração $F_{1}$, em que suas mães tiveram alimentação com alto teor de gordura durante a prenhez e lactação, mas que após o desmame fizeram ingestão de dieta padrão (grupo HFC) também apresentaram prejuízos na ejeção de leite; as ratas do grupo HFHF são as que apresentaram uma diminuição maior na capacidade de prover leite aos seus descendentes, pois apresentam além de um menor número total de ejeções, uma maior latência para a primeira ejeção de leite e também um maior intervalo entre cada ejeção. Combinados, esses fatos sugerem que a alimentação com dieta hiperlipídica em qualquer período da vida é deletério para a exibição de uma amamentação adequada, mas que quanto maior o período sob este tipo de dieta, maiores os prejuízos causados à lactação. Esta é a primeira vez em que fica demonstrado o impacto da alta ingestão de lipídeos pela mãe sobre o reflexo da ejeção de leite. Já foi demonstrado que as glândulas mamárias de roedores que consomem dieta rica em lipídeos apresentam severas alterações morfológicas (Buonfiglio et al., 2016; Hernandez et al., 2012), e é importante lembrar que além de mecanismos centrais, ações locais na glândula mamária podem regular o início e manutenção da lactação, o controle do fluxo sanguíneo local e a apoptose de células (Svennersten-Sjaunja, Olsson, 2005).

A deficiência no aleitamento materno no período inicial da vida pode levar à morte ou a mudanças no metabolismo da progênie, que futuramente pode resultar em obesidade e desordens metabólicas (Góes et al., 2012). O menor número de ejeções refletiu diretamente no peso da ninhada, sendo que os filhotes HFHF apresentaram menor peso ao longo da lactação, corroborando os dados de um menor fornecimento de leite. Ainda, a dieta padrão durante a gestação e lactação parece exercer um efeito benéfico em mães que passaram a ingerir dieta hiperlipídica após o desmame (CHF), porque sua ninhada não apresenta alterações no peso durante a lactação. Somente os filhotes machos apresentaram peso 
individual reduzido no fim da lactação, nos grupos CHF e HFHF o que indica maior sensibilidade do sexo masculino nessa fase. O alto consumo de lipídeos pela mãe durante a lactação faz com que os filhotes iniciem precocemente a ingestão de sólidos, sem interferir no comportamento de sucção dos mesmos (Kojima et al., 2016). Isso pode, portanto, ser um consequência dos problemas no fornecimento do leite pelas mães. Além disso, a alimentação materna rica em lipídeos altera a composição do leite (Bautista et al., 2016).

É sabido que o consumo de dieta rica em lipídeos e a obesidade promovem atrasos na lactogênese (Hernandez et al., 2012; Saben et al., 2014). Porém, os mecanismos de como a dieta afeta a lactação não estão completamente elucidados. Aqui serão discutidas as possíveis ações de dois hormônios, que se tem sua função alterada devido à elevada ingestão de gordura como sugerem estudos recentes (Buonfiglio et al., 2016; Hernandez et al., 2012; Perello, Raingo, 2013; Song et al., 2014), podem levar a prejuízos na lactação. São eles a oxitocina e a prolactina. É importante ressaltar, porém, que as hipóteses aqui discutidas não são excludentes e que os impactos de uma má nutrição materna sobre a lactação podem ser multifatoriais, com interferência de outros fatores não abordados neste trabalho.

Depois do parto, a secreção de leite não depende somente de mudanças fisiológicas que preparam a glândula mamária para a produção do leite, mas também para a disponibilidade deste nos ductos mamários e sua consequente ejeção (Góes et al., 2012). Portanto, a lactação pode ser dividida em dois processos majoritários: a síntese do leite e a ejeção do mesmo. A primeira é regulada principalmente pela prolactina, produzida na hipófise anterior, que também estimula o desenvolvimento da glândula mamária. Já a ejeção do leite é a liberação deste conteúdo sintetizado pelas mães. Essa liberação é induzida pelo pico de secreção do hormônio oxitocina na hipófise posterior em resposta ao estímulo de sucção dos filhotes, que ativam receptores neurais nos mamilos fazendo com que haja contração das células mamárias mioepiteliais (Woodside et al., 2008; 2012). Apesar de não ter sido possível realizar dosagens desses hormônios no presente trabalho, acreditamos que suas funções possam ter sofrido interferências do consumo alto consumo de lipídeos pela mãe, como será discutido a seguir.

A oxitocina além das funções de ação periférica no parto e na glândula mamária, entre outras, também atua como fator anorexigênico central (Leng et al., 2008). Porém, durante a lactação, o papel de sensor metabólico exercido pelos 
neurônios produtores de oxitocina nos núcleos paraventricular (PVN) e supra-óptico (SON) do hipotálamo é atenuado (Sladek et al., 2016), sendo que as células magnocelulares nesse sistema sofrem adaptações durante a prenhez e lactação (Russel et al., 2003; Theodosis et al., 2006). Interessantemente, há a expressão de receptores de leptina nos neurônios magnocelulares no PVN e no SON e também na glândula mamária (Buonfiglio et al. 2016; Hâkansson et al., 1998; Li et al., 2010; Perello, Raingo, 2013). Se por um lado a prenhez e a lactação fazem com que as fêmeas apresentem resistência ao estímulo de saciedade promovido pela leptina (Grattan et al., 2007), por outro a leptina promove o aumento da atividade elétrica de neurônios que sintetizam oxitocina no SON (Velmurugan et al., 2013). As lactantes $F_{1}$ com alimentação rica em lipídeos apresentaram baixos níveis de leptina comparados ao grupos com dieta controle após o desmame neste estudo. Assim, há a possibilidade de que a leptina tenha diminuído os disparos dos neurônios de oxitocina nas mães, provocando a diminuição nos reflexos de ejeção de leite. Já em um quadro de obesidade, há instalação do quadro de resistência à leptina, o que também se correlacionaria ao fato de mães obesas apresentarem problemas durante a amamentação, como demonstram os estudos (Donath, Amir, 2008; Nommsen-Rivers et al., 2010).

Em relação à prolactina, este hormônio tem sido associado há uma baixa resposta ao estímulo de sucção em mulheres obesas ou com sobrepeso (Rasmussen, Kjolhede, 2004). Buonfiglio et al., (2016) mostraram que camundongos fêmeas alimentadas com dieta hiperlipídica apresentam alterações no comportamento materno e resistência à ação da prolactina na glândula mamária e no hipotálamo. Sugerem ainda, assim como ocorre com a oxitocina, que a leptina parece estar envolvida nesse processo. Deste modo, a dieta rica em lipídeos também pode ser capaz de alterar as ações da prolactina. Agrega-se a isso o fato de que a oxitocina possui efeito estimulador sobre a secreção de prolactina, e viceversa, sendo essa interação fundamental para a manutenção dos complexos processos fisiológicos e endócrinos que ocorrem durante a lactação (Ghosh, Sladek, 1995; Kennett, McKee, 2011). Portanto, ambas podem afetar simultaneamente os mecanismos de ejeção de leite.

Além das possíveis alterações apresentadas que podem levar à prejuízos na ação da prolactina e da oxitocina na ejeção do leite, há um outro componente passível de alterar esse mecanismo que merece ser debatido: o sistema opióide. Os 
opióides estão diretamente ligados ao controle da expressão do comportamento materno, sendo que injeções periféricas de morfina ou $\beta$-endorfina inibem a expressão desse comportamento, enquanto que bloqueio central dos receptores desses neurotransmissores facilita sua exibição (Bridges, Grimm, 1982; Grimm, Bridges, 1983). Ao mesmo tempo, tem sido relatado o envolvimento do sistema opióide na ejeção de leite, sendo que injeções de naloxona, um antagonista de receptores opióides não-específico, aumentam os níveis de oxitocina durante a ordenha em vacas produtoras de leite, ao mesmo tempo que injeções de morfina inibem a liberação desse hormônio de maneira dose-dependente (Tancin et al., 2000). Em ratas, injeções de morfina no espaço subaracnóide, também de maneira dose-dependente, inibem os reflexos da ejeção do leite sugerindo que há um local na coluna vertebral em que os opióides atuam para inibir esse mecanismo (Wright, 1985). Por conseguinte, a ação modulatória dos opióides pode ser exercida de maneira central e periférica.

A expressão gênica e proteica dos receptores $\mu, \kappa$ e $\delta$ está significativamente aumentada nos animais que receberam dieta hiperlipídica em algum momento da vida, para ambas as gerações estudadas. No caso da geração $F_{1}$, o grupo HFHF é o que tem maior expressão desses componentes comparados a todos os demais grupos, e interessantemente, também é o que apresenta maiores prejuízos dos cuidados maternos na amamentação. É sabido que os opióides endógenos restringem a secreção de oxicitocina por meio da ação nos terminais de neurônios oxitocinérgicos na hipófise posterior e que isso parece ser regulado por dois diferentes mecanismos: agonistas $\mu$ е к opióides agem centralmente para inibir a atividade dos neurônios que produzem oxitocina, mas somente os agonistas $\mathrm{K}$ agem nos terminais de secreção do hormônio na hipófise (Russel et al., 1993). A porção neural da hipófise tem uma quantidade abundante de receptores $\kappa$, o que não se repete para os receptores $\mu$ e $\delta$ (Sumner et al., 1990). De modo concomitante, os genes e proteínas ligados ao receptor $\mathrm{k}$ opióde são os que tiveram maior expressão no grupo HFHF quando comparados aos outros tipos de receptores. Isso sugere que o sistema opióide endógeno está exacerbado nas mães que consumiram dieta rica em lipídeos, alterando os níveis de liberação de oxitocina e prejudicando, portanto, o reflexo de ejeção de leite.

Além da oxitocina, sabe-se de que prolactina também tem sua secreção modulada por opióides. Sistemas neuronais aferentes dos opióides endógenos 
facilitam a secreção de prolactina em várias condições fisiológicas, incluindo a prenhez e lactação, por meio da diminuição do tônus tuberoinfundibular dopaminérgico inibitório (Andrews, Grattan, 2003). Receptores opióides $\mu$ e k, e seus agonistas endógenos, estão envolvidos no aumento plasmático de prolactina em resposta ao estímulo de sucção dos filhotes (Tavakoli-Nezhad, Arbogast, 2010). Entretanto, passadas aproximadamente 4 horas de uma injeção aguda de morfina, há um declínio considerável nos níveis de prolactina por meio da estimulação da liberação de dopamina nesses mesmos neurônios (Gudelsky et al., 1986). Consequentemente, o elevado nível de expressão dos receptores opióides encontrado pode indicar ações sobre a prolactina a longo prazo.

Assim, com base nos dados apresentados pode-se concluir que a nutrição materna interfere na exibição do comportamento materno e na amamentação, porém os mecanismos pelos quais isso acontece permanecem desconhecidos e precisam ser elucidados, sendo alvo para futuros estudos (Connor et al., 2012, Kundakovic, Champagne, 2015).

\subsection{Alterações bioquímicas e hormonais}

Os machos, tantos nas análises bioquímicas quanto hormonais realizadas não apresentaram diferenças significativas entre os grupos nos DPN35, 70 e 120. Curiosamente, os grupos CHF e HFHF aos 35 dias de vida apresentavam peso menor que os demais grupos, aos 70 dias de vida essa diferença não existia mais, e aos 120 dias esses machos apresentavam uma maior adiposidade em relação aos grupos CC e HFC, porém essas diferenças corporais não foram acompanhadas de alterações metabólicas nesses animais. Sánchez-Garrido et al., (2013) também não encontraram diferenças nos níveis plasmáticos de insulina em machos num modelo de super-nutrição durante a lactação e alimentação rica em lipídeos após o desmame, mesmo esses animais tendo maior peso corporal que os controles. Já Cordero et al., (2012) observaram níveis mais baixos apenas de HDL-colesterol em machos que receberam dieta com alto índice calórico desde a concepção em relação aos animais que receberam a mesma dieta apenas na vida adulta, sendo que o mesmo padrão não foi observado nas fêmeas.

Entre as mães, as fêmeas da geração $F_{1}$ foram os únicos animais que apresentaram alterações significantes nos parâmetros bioquímicos e hormonais 
analisados. As fêmeas dos grupos HFHF e CHF apresentavam níveis séricos de colesterol e LDL-colesterol elevados em relação aos grupos CC e HFC. Cordero et al. (2012) encontraram baixos níveis de triglicerídeos em ratas alimentadas com dieta rica em lipídeos e açúcares na vida adulta, independente da dieta materna. Porém é importante ressaltar que neste estudo as mães $F_{1}$ apresentaram alterações nos parâmetros bioquímicos apenas quando houve a alteração do estado fisiológico destes animais, sendo que antes da prenhez não havia diferenças entre os grupos para esses dados. Assim, o desafio da gestação e lactação parece impor mudanças ao organismo da fêmea que lhe trazem alterações prejudiciais quando estão sobre alimentação hiperlipídica. Além disso, mostra-se que o peso corpóreo não precisa necessariamente estar aumentado para que as alterações metabólicas latentes deletérias ao organismo estejam presentes. Outros estudos também encontraram alterações metabólicas sem que o peso dos animais se mostrasse alterado com a ingestão de dieta rica em gordura (Heinonen et al., 2014).

Ainda sobre as mães, somente o grupo HFHF apresentou altos níveis da enzima ALT no soro, o que indica um certo grau de compromentimento hepático. O fato de que as mães $F_{1}$ que consumiram dieta hiperlipídica desde o período prépubere (CHF e HFHF) têm o fígado mais leve, mas somente o grupo HFHF mostra indícios de prejuízo da função hepática, nos leva a crer que a dieta controle materna exerceu um certo efeito protetor sobre os impactos da má-nutrição dos filhos na vida adulta. Ademais, as mães HFHF são as que apresentam maiores prejuízos na amamentação dos filhotes. No que diz respeito aos filhotes machos, também houve maiores diferenças no grupo HFHF em relação à ingestão alimentar durante a peripuberdade, onde os filhotes CHF ingeriram uma menor quantidade de calorias que o grupo HFHF, e apenas este último grupo apresenta maiores valores de tecido adiposo perigonadal e retroperitoneal.

Outro dado que nos mostra a importância da dieta materna sobre a vida do descente é o fato de que as fêmeas HFC e HFHF apresentam maiores níveis séricos de insulina no DPN70. Fêmeas que foram submetidas a um excesso de nutrição materna durante o inicio da vida pós-natal, por meio de um número reduzido de filhotes na ninhada, também apresentaram níveis elevados de insulina na vida adulta independente da dieta ingerida neste período (Sáchez-Garrido et al., 2013). Isso nos leva à hipótese da "fetal origins of adult disease", ou origem fetal da doença no adulto (Barker, 1994, 1999, 2005). As doenças na vida adulta, tanto em animais de 
experimentação quanto em humanos, estão sendo associadas cada vez mais com os padrões de crescimento no início da vida, sendo a nutrição durante este período uma das responsáveis por esse mecanismo (Well, 2007). Assim, os nutrientes fornecidos na vida intra-uterina parecem programar o organismo dos descentes, sendo essas características transmitidas principalmente por meios epigenéticos, que não estão completamente estabelecidos ainda (Heerwagen et al., 2010, Sullivan et al., 2014). Além disso, tal programação aparentemente ocorre de forma diferente entre machos e fêmeas, sendo cada um dos sexos mais ou menos susceptível aos efeitos da nutrição materna em diferentes parâmetros, que não somente os metabólicos.

Ao final da lactação, as mães $F_{1}$ nos grupos CHF e HFHF apresentavam níveis reduzidos de leptina sérico. Este hormônio é produzido nos adipócitos e apresenta-se elevado em indivíduos obesos que possuem uma alta quantidade de gordura corporal. Tais indivíduos acabam tornando-se resistentes à suas ações. Em modelos animais de consumo de dieta rica em lipídeos, os resultados observados para os níveis de leptina são variáveis e dependem do período da vida que os animais foram expostos a ração e também por quanto tempo. Por exemplo, Strakovisky et al., (2011) e Desai et al., (2014) não observaram diferenças nos níveis de leptina em fêmeas gestantes alimentadas com dieta hiperlipídica desde antes da prenhez, como observado com as mães $F_{0}$ deste estudo. Já Buonfiglio et al., (2016), observaram níveis séricos elevados em camundongas durante a lactação que se tornaram obesas antes do acasalamento. As mães CHF e HFHF no presente estudo, não tornaram-se obesas. Pelo contrário, durante a gestação e lactação elas apresentaram um menor peso corporal e também possuíram uma tendência a quantidades ligeiramente menores de tecido adiposo em relação ao controle, o que pode ter relação com os baixos níveis de leptina encontrados. Acrescido a isso, temse $\mathrm{o}$ fato da lactação ter uma alta demanda metabólica/energética e da dieta hiperlipídica utilizada não favorecer o acúmulo de gordura corporal, como discutido anteriormente.

\subsection{Testes de preferência e a relação com opióides}

A capacidade de aprender com experiências positivas é importante para a sobrevivência do indivíduo. Estando associada à emoções positivas como 
recompensa, hedonismo e prazer, age no sentido de aumentar a probabilidade de ocorrência de determinado comportamento, em um fenômeno conhecido como reforço positivo. A comida é um dos estímulos promotores desse fenômeno, sendo ela oriunda de dieta líquida ou sólida (Le Merrer et al., 2009).

Neste sentido, além da necessidade da alimentação para obtenção de energia, o aspecto hedônico desse comportamento é muito importante, não só para os animais como também para os humanos. Os sistemas fisiológicos dos mamíferos se desenvolveram no sentido de que a busca pela sensação de sentir-se bem é primordial (de Graaf, 2006). Assim, alimentos palatáveis, especialmente os que contém açúcar, reforçam o prazer pela comida e não raramente levam ao seu consumo exagerado (Berthoud et al., 2011). Estudos têm mostrado que a ingestão de dieta palatável pela mãe pode aumentar a preferência por gordura e/ou açúcar nos descendentes (Bayol et al., 2007; Teegarden et al., 2009).

Todos os animais neste estudo, de ambos os sexos, preferiram consumir a solução de sacarose como era esperado. Porém, os grupos em que as mães receberam dieta rica em gordura não apresentaram um maior consumo comparado aos demais. Ratos machos expostos à dieta com teor moderado de gordura durante 5 semanas apresentam maior motivação por sacarose (Figlewicz et al., 2006). Vucetic et al., (2010) observaram que camundongos machos de mães com alimentação hiperlipídica antes e durante a lactação têm maior preferência pelo consumo de solução açucarada. Ainda, ao comparar animais obesos e animais que consumiram dieta rica em lipídeos mas que não se tornaram obesos, como aconteceu neste estudo, apenas os primeiros apresentam a preferência por sacarose alterada (Takase et al., 2016). Controversamente, embora a maioria dos estudos indique que há um aumento da preferência por alimentos palatáveis, há relatos na literatura de que animais que consomem dieta hiperlipídica apresentam uma redução da preferência por sacarose, e sugerem que isso se deva à perda do interesse por atividades prazerosas (Hu et al., 2014; Sharma et al., 2013; Takase et al., 2016). Portanto, aparentemente, a dieta hiperlipídica pode exercer influências diferentes sobre o indivíduo quando o animal consome a mesma diretamente, ou quando esse consumo é feito por seus pais. Isso demonstra que o papel do alto teor de lipídeos na dieta sobre a preferência por atividades que promovam a sensação de bem-estar precisa ser melhor investigado. 
A palatabilidade consiste de vários fatores, os quais incluem o teor de gordura e açúcar presente, e a variabilidade do alimento, resultando em um maior impacto hedônico (van den Heuvel et al., 2011). Em humanos, há diferenças individuais na percepção oral do teor de gordura do alimento. Um estudo realizado em voluntários demonstrou que quanto maior era a intensidade de percepção de lipídeos no alimento, menor era o índice de massa corporal, a circunferência abdominal do indivíduo e a ingestão de alimentos do tipo fast food, que possuem alta carga de gordura (Martínez-Ruiz et al., 2014). Roedores, assim como humanos, possuem preferência por comidas ricas em lipídeos quando lhes é dado opção de escolha (Gaillard et al., 2008). Assim, a quantidade de lipídeos do alimento é importante, até um ponto máximo em que esse componente deixa de ser prazeroso (Bolhuis et al., 2016). Neste sentido, um estudo realizado com alimentação rica em gordura de diferentes fontes durante a gestação e lactação, mostrou que machos com dieta hiperlipídica oriundos de mães que tiveram dieta rica em margarina apresentam menor peso corporal e menos tecido adiposo. Esses animais também apresentaram uma baixa preferência por alimentos gordurosos (Sánchez et al., 2012). A maioria dos estudos foca apenas no conteúdo de gordura das dietas embora a palatabilidade de um alimento também dependa da quantidade de açúcar que a compõe (van den Heuvel et al., 2011). A quantidade de alimento ingerida é determinada por hormônios de saciedade que são secretados em resposta ao tipo de nutriente ingerido, e também ao sabor que esses nutrientes apresentam (Begg, Woods, 2013; Calvo, Egan, 2015). Assim, muitas vezes a satisfação ou a resposta hedônica obtida ao comer sobrepõe os mecanismos de feedback para a saciedade, o que pode levar à obesidade.

A ração hiperlipídica utilizada neste estudo pode ter alterado a palatabilidade da mesma, devido ao alto teor lipídico e ao reduzido teor de carboidratos que ela apresenta. O tipo de ácido graxo e de triglicéride que compõem a dieta são importantes para a preferência do animal pela dieta rica em gordura (Fukuwatari et al., 2003; Tsuruta et al., 1999). Assim, talvez o longo tempo de exposição à dieta hiperlipídica, o que restringiu a variabilidade, fez com que os animais dos grupos CHF e HFHF durante o teste de preferência à gordura preferissem a ração controle, mas sem abolir completamente o seu consumo. Outro fato que corrobora essa hipótese é que entre os animais que ingeriam ração padrão antes do teste, a preferência pela ração hiperlipídica ficou em torno de $90 \%$ do consumo diário. 
Vucetic et al., (2010) observaram que filhotes machos de mães que receberem dieta hiperlipídica durante a prenhez e gestação apresentam maior preferência por gordura. Entretanto, após o desmame esses animais foram mantidos sob ração padrão até a vida adulta, quando foi realizado o teste. Ainda, as respostas entre os sexos para a preferência por gordura parecem ser diferentes, uma vez que somente $10 \%$ das fêmeas que consumiam ração hiperlipídica após o desmame aboliram completamente o consumo dessa ração durante o teste. Entre os machos esse valor ficou entre 55 e $60 \%$ dos animais. Assim, sugere-se que as fêmeas sejam menos sensíveis à percepção do teor de gordura no alimento, ou que o consumo de lipídeos promova maior prazer nos animais deste sexo. Concordantemente, as fêmeas parecem ter os mecanismos de recompensa mais aguçados que os machos, uma vez que ratas quando apresentadas a um alimento doce antes de poderem se auto-administrarem cocaína, diminuem a quantidade de droga consumida. Esse efeito do recompensador natural é menos pronunciado em machos (Cason, Grigson, 2013).

Um aspecto importante que merece ser incluído nessa discussão é o papel dos opióides na alimentação, tendo em vista que os animais que receberam dieta hiperlipídica em algum momento da vida apresentaram altos níveis de expressão gênica e proteica dos receptores opióides. Esse sistema está envolvido no reforço promovido pela dieta, seja esta líquida ou sólida, sendo seus receptores amplamente distribuídos em áreas ligadas ao sistema recompensa, como a área tegmentar ventral e o núcleo accumbens (Treesukosol et al., 2014). Porém, em outras regiões do cérebro como o hipotálamo, também participa do aspecto homeostático da alimentação, no sentido de promover a ingestão de alimentos para suprir as demandas energéticas (Le Merrer et al., 2009). A naltrexona, um antagonista dos receptores opióides, quando injetada diretamente no núcleo paraventricular do hipotálamo promove a redução da ingestão do alimento preterido e do favorito pelo animal, indicando que o sistema opióide nessa área atua em ambos os aspectos da alimentação (Glass et al., 2000).

Opióides liberados no núcleo accumbens durante o consumo de alimentos palatáveis podem produzir efeitos opostos na preferência alimentar dependendo do tipo de receptor que eles ativam (Woolley et al., 2007). O receptor $\mu$-opióde quando ativado favorece a ingestão de alimentos que o animal exibe preferência, enquanto que o receptor $\mathrm{k}$ opióide facilita o consumo da dieta de sabor não-preferido (Woolley 
et al., 2006). Já no hipotálamo, a estimulação aguda dos receptores opiódes $\mu$ e $\mathrm{K}$, mas não o $\delta$, induz a ingestão de alimentos (Dutia et al., 2012; Mountjoy et al., 2010). Além disso, jejum e restrição alimentar crônica levam a diminuição dos níveis de $\beta$-endorfina no hipotálamo (Mercer et al., 2014). Assim, um aumento da expressão de receptores opióides no hipotálamo, como observado neste estudo, levanta a hipótese de que possivelmente há mais intensidade na transmissão opioidérgica nessa região do cérebro, modulada pelo alto consumo lipídico. Tendo em vista que o estímulo promovido por opióides aumenta 0 apetite e que 0 hipotálamo participa desse controle, é possível que a alteração observada na expressão dos receptores opióides esteja envolvida nas mudanças dos padrões de consumo alimentar observadas nos animais que consumiram ração hiperlipídica.

Filhotes de animais de laboratório alimentados com uma dieta rica em lipídeos ou "junk food", comparados a animais de mães mantidas com ração padrão durante a prenhez e lactação mostram alterações na expressão gênica de proteínas de sinalização opioidérgica (Ong, Muhlhausler, 2011; Vucetic et al., 2010). No mesmo sentido, o grupo HFC apresenta maiores níveis de expressão dos opióides que o grupo controle, porém sem apresentar maior preferência por gordura quando comparado a esse grupo. Isso demonstra que o consumo de dieta hiperlipídica parental é capaz de programar sistemas neurais básicos dos descendentes durante a gestação e lactação. Há estudos que indicam que a obesidade antes da concepção é capaz de alterar o desenvolvimento do sistema opióide (Grissom et al., 2014). Olszewski et al., (2011) sugerem que os opióides estão ligados a mecanismos de recompensa por qualquer tipo de comida, seja ela palatável, insossa ou potencialmente danosa ao organismo, agindo por diferentes vias em diferentes áreas do cérebro. Indicam ainda que o simples fato de comer para saciar a necessidade energética também ativa mecanismos opioidérgicos de recompensa. Isso pode estar relacionado ao fato de que apesar dos grupos CHF, HFC e HFHF terem maior expressão dos receptores opióides, nenhum deles apresenta maior preferência por gordura do que o grupo controle.

Em animais divididos em grupos de acordo com a preferência por sacarose ou por gordura, um agonista $\mu$ opióide injetado diretamente no núcleo paraventricular do hipotálamo aumentou o consumo de gordura em animais que preferiam esse tipo de alimento, enquanto que não apresentou interferências no consumo de nenhuma das dietas de animais que preferiam sacarose (Nailed et al., 2007). Isso indica que o 
papel dos opióides, principalmente no hipotálamo, é complexo em relação a ingestão alimentar com a preferência, o tipo de nutriente e o estado energético afetando a habilidade desses componentes em alterar o comportamento do animal. No geral, a natureza do efeito dos opióides na seleção da dieta precisa ser melhor elucidada, havendo a possibilidade de que opióides endógenos e exógenos tenham ações diferentes na escolha das preferências alimentares (Gosnell, Levine, 2009; Nailed et al., 2007; Taha, 2010). Porém, a importância desse sistema na indução do apetite e na escolha por alimentos com alta densidade energética é inegável, uma vez que opióides têm sido alvo de estratégias farmacológicas para o desenvolvimento de drogas que possam combater a obesidade (Bojanowska, Ciosek, 2016). Outros aspectos relacionados ao aumento da expressão dos receptores opióides e o comportamento maternal foram abordados na seção 5.1 .

\subsection{Machos adultos no DPN120}

A alimentação rica em lipídeos por um longo período (aproximadamente 18 semanas) parece ter influenciado principalmente a composição corporal nos machos, uma vez que os animais CHF e HFHF apresentam maior adiposidade corporal. Entretanto, os efeitos da alimentação materna durante a gestação e lactação parecem somar-se aos efeitos da dieta pós-desmame nos animais, sendo o grupo HFHF o que apresenta maior quantidade de tecido adiposo retroperitoneal e retrogonadal, mostrando a importância da alimentação materna sobre a vida do descendente. Essas diferenças do tecido adiposo não se refletiram no peso corporal dos animais, talvez devido à composição da dieta utilizada, como discutido anteriormente.

Em um estudo em que foram testadas diferentes composições de dieta hiperlipídica (ácidos graxos saturados, ácidos graxos poli-insaturados, e um terceiro grupo com ambos os tipos misturados) todos os animais apresentaram maior peso corporal ao final do estudo (Campos-Silva et al., 2015). Entretanto, apesar de os animais serem expostos a esse tipo de alimentação por tempo semelhante ao do presente trabalho (16 semanas), o início da exposição se deu aos 3 meses dias de vida, tendo os machos no final do experimento 7 meses de idade, o que é considerado um animal de idade avançada. Assim, isso levanta a possibilidade de que se os machos fossem mantidos por mais tempo na alimentação hiperlipídica, 
alterações no peso corporal seriam observadas. Corrobora essa hipótese o fato de que aos 35 dias de vida os machos dos grupos CHF e HFHF tinham peso menor que o controle, diferença que não existia mais aos 70 dias pós-natal, chegando aos 120 dias com maior adiposidade corporal. Deste modo, mais uma vez ressalta-se a importância do período e do tempo de exposição da dieta nos os efeitos provocados sobre o indivíduo.

Da mesma forma que em outros estudos que resultaram em animais obesos ou com maior adiposidade corporal induzidos por dieta, não foram encontradas diferenças nos níveis de colesterol total, HDL-colesterol e triglicérides nos machos adultos alimentados com ração rica em lipídeos em qualquer período da vida (Campos-Silva et al., 2015; Lemus et al., 2015; Mucellini et al., 2014).

Não foram observadas diferenças comportamentais relacionadas à ansiedade nos machos adultos, independente do período em que foram expostos à dieta hiperlipídica. Nos últimos anos, estudos epidemiológicos têm mostrado uma associação entre a obesidade e alterações metabólicas maternas e o aumento de desordens neuropsiquiátricas nos filhos, estando os distúrbios relacionados à ansiedade entre essas doenças (Colman et al., 2012; Rodriguez, 2010; Van Lieshout et al., 2013). A maioria dos estudos em roedores que empregam o consumo de dietas rica em lipídeos pela mãe ou pelo próprio indivíduo estão de acordo com esses achados, sendo que os animais apresentam um aumento dos comportamentos semelhantes à ansiedade (Peleg-Raibstein et al., 2012; Sasaki et al., 2013; Sharma et al., 2013; Zemdegs et al., 2015). Machos são naturalmente menos propensos à expressar comportamentos de ansiedade do que fêmeas (Bilbo, Tsang, 2010; Sullivan et al., 2010). Isso faz com que talvez haja a necessidade de uma intensa interferência externa para que existam alterações comportamentais passíveis de detecção nesses animais. Assim, nesse caso a dieta rica em gordura pode não ter sido um agente forte o suficiente para causar impactos detectáveis nos machos adultos.

Além dos aspectos relacionados à dieta, quando esta interfere na qualidade do comportamento maternal expressado pelas mães, isso pode indiretamente programar diferenças no comportamento dos filhotes (Bagot et al., 2009; Parent, Meaney, 2008). Entretanto, os déficits dos cuidados maternos que levam ao aumento da ansiedade nos descentes estão mais relacionados à aspectos de atenção e grooming dos filhotes (Weaver et al., 2006), o que não aconteceu nesse 
estudo, como descrito anteriormente (ver seção 5.1), e pode portanto ter relação com a ausência de alterações comportamentais semelhantes à ansiedade apresentada pelos machos.

Por outro lado, apesar dos inúmeros estudos que relatam o aumento da ansiedade devido ao consumo de alimentos hiperlipídicos e à obesidade, há relatos de que essa situação seja ansiolítica (Maniam et al., 2016; McNeilly et al., 2015). Ainda, o período da vida e a duração do tempo em que esses animais são expostos a essa dieta parecem interferir diretamente com a expressão comportamental (Sullivan et al., 2014). Logo, apesar de ser evidente a ação de desordens metabólicas sobre comportamentos neuropsicológicos, os dados da literatura são recentes e controversos, sendo mais estudos necessários a fim de avaliar o real efeito da nutrição sobre o desenvolvimento da ansiedade. É importante ressaltar também que $\mathrm{o}$ aumento de distúrbios neuropsiquiátricos e do neurodesenvolvimento constatados atualmente não é devido somente à obesidade materna e ao consumo exagerado de calorias, mas também ao advento de novas tecnologias diagnósticas e ao crescimento da conscientização sobre essas doenças (Rivera et al., 2015).

Em homens, assim como em roedores, a deficiência de sinalização da leptina leva a uma atividade reduzida dos neurônios $\mathrm{GnRH}$, causando um estado hipogonadal (Farooqi et al., 2007; Sheffer-Babila et al., 2013). Assim, há uma evidência inegável entre o status metabólico e a atividade gonadal (Michalakis et al., 2013). Jacobs et al. (2014) observaram que machos adultos oriundos de mães com dieta do tipo cafeteria durante toda a prenhez e lactação apresentam níveis reduzidos de testosterona, do hormônio luteinizante $(\mathrm{LH})$ e do hormônio folículo estimulante (FSH), impactando negativamente na função reprodutiva desses animais. No presente estudo, houve apenas uma tendência dos machos que receberam dieta hiperlipídica após o desmame em apresentarem prejuízo na exibição do comportamento sexual. É sabido que o excesso de tecido adiposo resulta em aumento da conversão de testosterona em estradiol (Michalakis et al., 2013). Apesar dos animais dos grupos CHF e HFHF apresentarem uma maior adiposidade corporal, isso não resultou em alterações significativas na performance sexual e no peso dos órgãos do aparelho reprodutor dos mesmos. No mesmo sentido, ratos alimentados com diferentes composições de dieta hiperlipídica 
apresentaram aumento da adiposidade e peso corporal, porém sem alterações nos níveis de testosterona e no peso testicular (Campos-Silva et al., 2015).

\subsection{Expressão gênica dos fatores de transcrição neurais durante a gestação}

Uma vez demonstrado que a dieta hiperlipídica materna interfere com o desenvolvimento dos filhotes, os quais apresentam alterações comportamentais e metabólicas significativas durante a vida, buscou-se investigar um possível mecanismo de como essa programação acontece durante a gestação. Para isso foram analisados a expressão gênica de fatores de transcrição neurais que regulam o destino e expressão de células hipotalâmicas durante o desenvolvimento fetal.

Tem sido proposto que a exposição do embrião/feto à alta ingestão de nutrientes por parte da mãe resulta em mudanças permanentes na rede neural de regulação do apetite (Muhlhausler et al., 2006). O período de maturação para o desenvolvimento dos sistemas de controle do balanço energético em roedores é nas primeiras duas a três semanas de vida. No nascimento, essas vias ainda estão imaturas e os primeiros dias de vida pós-natal são o período em que as projeções neuronais são consolidadas (Bouret et al., 2004; Bouret, Simerly, 2006; Djiane, Attig, 2008; Sullivan et al., 2011). Animais expostos a disruptores endócrinos e dieta hiperlipídica durante esta fase apresentam redução de inervação das fibras POMC para o núcleo paraventricular do hipotálamo (Mackay et al., 2013; Sullivan et al., 2015). Porém, há poucos estudos que analisaram se a dieta rica em lipídeos pode interferir com a fase de proliferação neuronal do sistema de melanocortina no período gestacional, sendo que já foi demonstrado que a obesidade materna pode programar o sistema de recompensa dos descentes na prenhez (Grissom et al., 2014).

Nenhum dos fatores de transcrição analisados (Ngn3, Mash1, Rax e Six3) durante o desenvolvimento embrionário sofreram interferências na sua expressão devido à ingestão materna de altas concentrações de lipídeos. Camundongos knockout para o gene da Ngn3 mostraram altos níveis de expressão gênica, neuronal e de fibras neurais do NPY no núcleo arqueado, enquanto que não houve diferenças nos níveis de expressão do mRNA para o AgRP entre os animais mutantes e os wild-type (Arai et al., 2010). No presente estudo também foram encontrados maiores níveis de expressão gênica do NPY no $18^{\circ}$ dia de gestação, e 
do mesmo modo nenhuma diferença para o AgRP, porém a dieta hiperlipídica materna não foi capaz de alterar a expressão do Ngn3 ou qualquer outro fator de transcrição. Do mesmo modo, Desai et al., (2016) também não encontraram diferenças na expressão de Ngn3 em filhotes com um dia de vida provenientes de mães com alimentação rica em lipídeos por 11 semanas antes e durante a gestação, porém observaram um expressão menor de Mash1, sem alterar os níveis de POMC. A expressão do peptídeo AgRP eram 1,4 vezes maior que o controle nesses animais. Além do cérebro, o Ngn3 também é expresso em células enteroendócrinas em animais adultos, estando também relacionado ao controle da diferenciação dessas células. Diferentemente do que foi visto no presente estudo, a dieta rica em lipídeos faz com que a expressão de Ngn3 nessas células diminua (Sakar et al., 2014).

O sexo dos embriões utilizados neste estudo não foi avaliado, e isso pode ter interferido nos resultados aqui encontrados. Os sistemas fisiológicos que regulam a ingestão alimentar e o balanço energético são sexualmente diferenciados (Shi et al., 2008; 2009). O Ngn3 está envolvido na diferenciação sexual do encéfalo e age antes dos picos hormonais que geralmente levam a essa diferença, sendo que neurônios femininos apresentam uma elevada síntese de neuritos e maior expressão de Ngn3 do que neurônios masculinos (Scerbo et al., 2014). Portanto, uma avalição futura da expressão de Ngn3 sob os efeitos da dieta hiperlipídica diferenciando os indivíduos entre machos e fêmeas seria interessante. Talvez, um sexo pode ser mais influenciado do que outro como tem sido visto em animais adultos e em alguns parâmetros do presente estudo (Desai et al., 2014; MacKay et al., 2003).

Dados da literatura mostram que o consumo de dieta rica em lipídeos durante a prenhez e lactação favorece a ativação de vias orexigênicas, enquanto que vias anorexigênicas são suprimidas nos animais adultos (Bouret, 2009; Chang et al., 2008). Nestes, quando submetidos à dieta rica em gordura por no mínimo dois meses, não há diferenças no número de neurônios NPY e POMC no núcleo arqueado, sendo o volume dessas células que apresenta-se alterado, principalmente dos neurônios NPY (Lemus et al., 2015), o que mostra diferenças em relação ao período de exposição à dieta. Curiosamente, houve maior expressão gênica para ambos NPY e POMC nos estágios finais da gestação (DG18). Chen e Morris (2009) observaram que filhotes aos 20 dias de vida, oriundos de mães obesas, apresentam maior expressão hipotalâmica de POMC, independentemente de estarem ou não 
previamente alimentados. Assim, no presente estudo essa alteração já foi observada em períodos ainda mais iniciais da vida do descendente. Do mesmo modo, cordeiros provenientes de ovelhas super-nutridas, nos quais a rede neural de regulação do apetite desenvolve-se antes do nascimento assim como em humanos, têm maior expressão de POMC (Muhlhausler et al., 2006). Em ensaios in vitro, a leptina induz o crescimento de neuritos em neurônios do núcleo arqueado e também é um importante fator neurotrófico durante o desenvolvimeno do hipotálamo, sendo necessária ao desenvolvimento regular das fibras a-MSH e AgRP no núcleo paraventricular (Bouret et al., 2004). Assim, é possível que a dieta hiperlipídica induza a níveis elevados de leptina no ambiente intrauterino, favorecendo a expressão aumentada do mRNA de NPY e POMC. É importante frisar que a ração utilizada nesse experimento era composta por $60 \%$ de lipídeos, oriundos principalmente de banha animal, o que fez com que as mães high-fat apresentassem peso ligeiramente maior que as controles já no DG18 (dados não mostrados), e poderiam, portanto, também apresentar diferenças nos níveis de leptina plasmática, caso tivessem sido mensurados. O cérebro dos fetos aparentemente não apresentou resistência à ação da leptina uma vez que a expressão de SOCS3 não era diferente dos animais controles nos estágios finais de desenvolvimento analisados, o que significa que a leptina estaria exercendo sua função normalmente nesses animais.

Além da maior expressão de mRNA, aparentemente o número de neurônios imuno-reativos para a POMC no núcleo arqueado é maior nos fetos de mães sob dieta hiperlipídica, o que indica que o RNA está sendo traduzido. Sabe-se que a exposição à dieta com alto teor de gordura durante a gestação estimula a proliferação de células neurais e neuroepiteliais do terceiro ventrículo, aumentando sua migração para regiões hipotalâmicas (Chang et al., 2008). Filhotes das mães com dieta hiperlipídica mostram um aumento na proporção de neurônios expressando peptídeos orexigênicos na vida adulta (Chang et al., 2008). Deste modo, mais estudos são necessários a fim de investigar o que provoca essa troca entre um elevado número de células que expressam peptídeos anorexigênicos em estágios iniciais da vida para maiores níveis de peptídeos orexigênicos em períodos tardios, o que favorece a hiperfagia e obesidade na vida adulta. Foram testados os níveis de expressão de mRNA da PC1, PC2 e MC4R com o intuito de avaliar se o POMC superproduzido estaria sendo regularmente clivado em seus produtos 
funcionais, ou se o a-MSH teria menor quantidade de receptores para exercer sua ação, o que levaria a supressão das vias anorexigênicas balanceando o aumento nos níveis de POMC, mas nenhuma diferença significante foi encontrada.

A maioria dos estudos que avaliam o consumo de dieta rica em lipídeos e sua influência nos circuitos de balanço energético utiliza-se de indivíduos que são obesos antes da gestação. Neste experimento, a exposição aos elevados níveis de gordura teve início no dia em que a prenhez foi confirmada e ainda sim foi possível identificar alterações significantes no desenvolvimento dos filhotes. Portanto, isto mostra que a programação metabólica exercida pela obesidade e pelo alto consumo de gordura é ampla e age de acordo com diferentes padrões promovendo efeitos prejudiciais aos descendentes desde estágios iniciais do desenvolvimento embrionário até a vida adulta.

\subsection{Considerações finais}

O consumo de dieta hiperlipídica pelas mães desde o início de sua vida causou prejuízos ao desenvolvimento dos filhotes, promovendo alterações no peso corporal ao longa da vida, nos padrões de consumo alimentar e nos parâmetros metabólicos. Tais alterações foram programadas, em parte, durante a vida intrauterina e nos primeiros dias de vida pós-natal, apresentando diferenças de ação entre os sexos dos descendentes em alguns aspectos. Deste modo, é inegável a importância que o ambiente nutricional materno durante período perinatal exerce sobre o desenvolvimento dos filhotes até na vida adulta. Também foram observados efeitos diretos do consumo de ração hiperlipídica nas mães, onde a dieta promoveu reduções significativas nos parâmetros de ejeção de leite materno e aumentou a expressão dos receptores opióides nas lactantes, o que indiretamente também possui efeitos importantes sobre os descendentes.

Com exceção de alguns períodos, o consumo calórico dos animais não diferiu da quantidade de calorias ingeridas pelo grupo controle, o que fez com que apesar de estarem consumindo uma dieta rica em lipídeos, os animais deste estudo não se tornassem obesos. Todavia, este fato não os impediu de desenvolverem alterações metabólicas e de desenvolvimento significativas. Do mesmo modo, animais alimentados com dieta hiperlipídica tendo o consumo calórico pareado ao dos animais controle, portanto animais não-obesos, apresentaram comportamentos 
alterados em relação à olfação, interações sociais e recompensas. Isso reforça a ideia de que o consumo de dieta hiperlipídica em si é prejudicial, independentemente da obesidade (Takase et al., 2016).

Existem vários estudos na literatura que reportam resultados sobre a utilização de dieta materna com alto teor de lipídeos na gestação e lactação. Entretanto, esses dados são muito contraditórios entre si devido à variabilidade da composição da ração hiperlipídica, da fonte de lipídeos utilizada, do período e da duração da exposição em que os animais são submetidos a essa alimentação. As diferenças entre os tipos de ácidos graxos da dieta está começando a ser elucidada (Mennitti et al., 2015), porém isso muitas vezes não é levado em consideração e acaba dificultando a discussão dos dados obtidos, gerando controvérsias. Outro aspecto importante a ser considerado são as diferenças na composição da própria dieta controle em si. O conteúdo de gordura apresentado nessas rações pode variar de 4 a 16\% entre os estudos, o que é passível de resultar em dados completamente diferentes quando se compara uma dieta hiperlipídica com rações controles de diferentes composições. Além da gordura, o conteúdo de proteínas e carboidratos nas dietas padrões variam consideravelmente (van den Heuvel et al., 2011). Assim, os cuidados e padronizações necessários com a dieta hiperlipídica são importantes da mesma forma com a dieta controle para a obtenção de resultados precisos, confiáveis e reprodutíveis. 
"A ciência poderá ter encontrado a cura para a maioria dos males, mas não achou ainda remédio para o pior de todos: a apatia dos seres humanos." Helen Keller

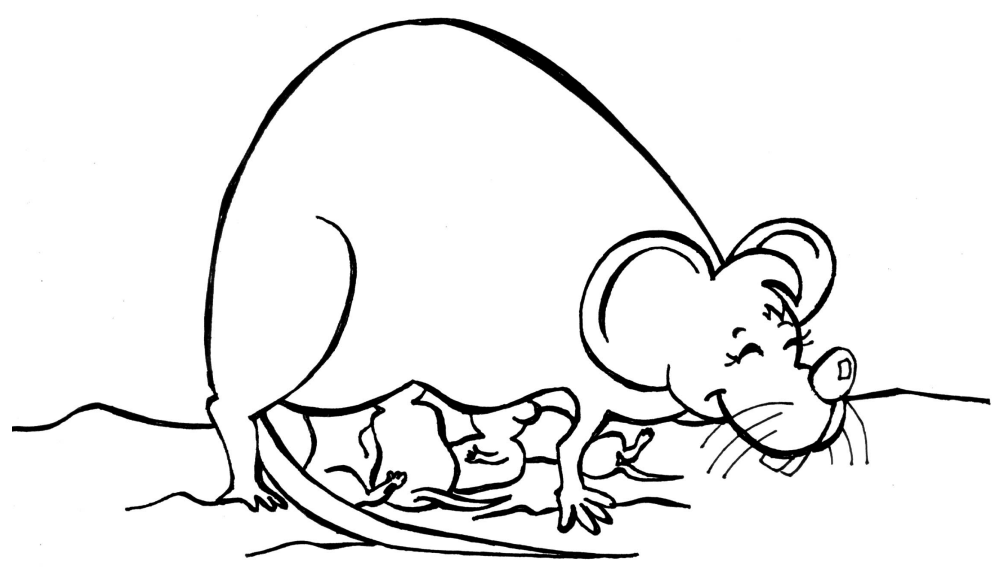


- O consumo de dieta hiperlipídica pelas mães trouxe prejuízos para as mesmas, promovendo alterações metabólicas (intolerância a glicose nas mães $F_{0}$, e aumento dos níveis de colesterol total e LDL-colesterol nas mães $F_{1}$ ) e um menor peso principalmente durante a lactação.

- Ambas as gerações apresentaram prejuízos no comportamento materno em relação aos parâmetros de ejeção do leite, sendo o HFHF na geração $F_{1} \circ$ grupo com alterações mais severas, o que resultou em redução do ganho de peso dos filhotes. Entretanto, todas as mães $F_{1}$ que receberam dieta hiperlipídica em algum momento da vida apresentaram um menor número de ejeções de leite, ressaltando a importância da nutrição materna na programação metabólica dos descendentes.

- As mães $F_{0}$ e $F_{1}$ que receberam dieta rica em lipídeos em qualquer período da vida (grupos HF, CHF, HFC e HFHF) tiveram aumento da expressão dos receptores opióides no hipotálamo.

- O estado fisiológico parece exercer papel importante na maneira com que os animais respondem à alta ingestão de lipídeos.

- No período peripuberal machos e fêmeas aumentam significativamente seu consumo calórico de dieta rica em lipídeos, apresentando diferenças entre os sexos no padrão alimentar.

- O consumo de ração hiperlipídica por um longo período fez com que a preferência por essa dieta fosse menor no teste de preferência alimentar, sem promover alterações na preferência por sacarose.

- Nos machos adultos, a dieta com alto teor de gordura não promoveu alterações nos comportamentos semelhantes à ansiedade, mas houve uma tendência de redução da performance reprodutiva no comportamento sexual. Os animais sob essa alimentação, principalmente o grupo HFHF, apresentaram maior adiposidade corporal.

- A dieta rica em gordura materna promoveu alterações no sistema melanocortina dos descendentes, aumentando a expressão de POMC e NPY ainda durante a gestação.

- Apesar de ingerirem uma dieta rica em lipídeos, os animais neste estudo não se tornaram obesos, fato que não os impediu de desenvolver alterações metabólicas, comportamentais e de desenvolvimento significativas. 
- Os efeitos deletérios promovidos pela dieta rica em gordura materna durante a prenhez e lactação parecem somar-se aos efeitos do consumo dos lipídeos pelo indivíduo, apresentando efeitos sinérgicos onde o grupo HFHF é o mais afetado.

- Os dados da literatura são controversos devido à variabilidade da composição da ração e do período de exposição da dieta hiperlipídica. Assim, mais atenção a essas variáveis precisam ser empregadas para obtenção de dados precisos e coesos sobre a influência da nutrição materna na vida dos filhotes. 


\section{REFERÊNCIAS*}

Aerts L, Van Assche FA. Animal evidence for the transgenerational development of diabetes mellitus. Int J Biochem Cell Biol. 2006;38(5-6):894-903.

Ainge $\mathrm{H}$, Thompson C, Ozanne SE, Rooney KB. A systematic review on animal models of maternal high fat feeding and offspring glycaemic control. Int $\mathrm{J}$ Obes (Lond). 2011;35(3):325-35.

Alfaradhi MZ, Ozanne SE. Developmental programming in response to maternal overnutrition. Front Genet. 2011;2:27.

Andrews ZB, Grattan DR. Opioid receptor subtypes involved in the regulation of prolactin secretion during pregnancy and lactation. J Neuroendocrinol. 2003;15(3):227-36.

Anthwal N, Pelling M, Claxton S, Mellitzer G, Collin C, Kessaris N et al. Conditional deletion of neurogenin-3 using Nkx2.1iCre results in a mouse model for the central control of feeding, activity and obesity. Dis Model Mech. 2013;6(5):1133-45.

Arai Y, Gradwohl G, Kameda Y. Expression of neuropeptide $Y$ and agouti-related peptide in the hypothalamic arcuate nucleus of newborn neurogenin3 null mutant mice. Cell Tissue Res. 2010;340(1):137-45.

Ashwood P, Kwong C, Hansen R, Hertz-Picciotto I, Croen L, Krakowiak P, et al. Brief report: plasma leptin levels are elevated in autism: association with early onset phenotype? J Autism Dev Disord 2008;38:169-75.

Bagot RC, van Hasselt FN, Champagne DL, Meaney MJ, Krugers HJ, Joëls M. Maternal care determines rapid effects of stress mediators on synaptic plasticity in adult rat hippocampal dentate gyrus. Neurobiol Learn Mem. 2009;92(3):292-300.

Barker DJ. The developmental origins of insulin resistance. Horm Res. 2005;64 Suppl 3:2-7.

Barker DJ. The intra-uterine origins of disturbed cholesterol homeostasis. Acta Paediatr. 1999;88(5):483-4.

Barker DJ. The Wellcome Foundation Lecture, 1994. The fetal origins of adult disease. Proc Biol Sci. 1995;262(1363):37-43.

Barker, DJ. Fetal programming of coronary heart disease. Trends Endocrinol Metab. 2002;13(9):364-8.

Bautista CJ, Montaño S, Ramirez V, Morales A, Nathanielsz PW, Bobadilla NA, Zambrano $\mathrm{E}$. Changes in milk composition in obese rats consuming a high-fat diet. Br J Nutr. 2016;115(3):538-46. 
Bayol SA, Farrington SJ, Stickland NC. A maternal 'junk food' diet in pregnancy and lactation promotes an exacerbated taste for 'junk food' and a greater propensity for obesity in rat offspring. Br J Nutr. 2007;98(4):843-51.

Begg DP, Woods SC. The endocrinology of food intake. Nat Rev Endocrinol. 2013;9(10):584-97.

Bermejo-Alvarez P1, Rosenfeld CS, Roberts RM. Effect of maternal obesity on estrous cyclicity, embryo development and blastocyst gene expression in a mouse model. Hum Reprod. 2012;27(12):3513-22.

Berthoud HR, Lenard NR, Shin AC. Food reward, hyperphagia, and obesity. Am J Physiol Regul Integr Comp Physiol. 2011;300(6):R1266-77.

Bilbo SD, Tsang $\mathrm{V}$. Enduring consequences of maternal obesity for brain inflammation and behavior of offspring. FASEB J. 2010;24:2104-2115.

Bodnar RJ. Endogenous opiates and behavior: 2014. Peptides. 2016;75:18-70.

Bohlen TM, Silveira MA, Zampieri TT, Frazão R, Donato J Jr. Fatness rather than leptin sensitivity determines the timing of puberty in female mice. Mol Cell Endocrinol. 2016;423:11-21.

Bojanowska E, Ciosek J. Can We Selectively Reduce Appetite for Energy-Dense Foods? An Overview of Pharmacological Strategies for Modification of Food Preference Behavior. Curr Neuropharmacol. 2016;14(2):118-42.

Bolhuis DP, Newman LP, Keast RS. Effects of Salt and Fat Combinations on Taste Preference and Perception. Chem Senses. 2016;41(3):189-95.

Bouret SG, Draper SJ, Simerly RB. Trophic action of leptin on hypothalamic neurons that regulate feeding. Science. 2004;304(5667):108-10.

Bouret SG, Simerly RB. Developmental programming of hypothalamic feeding circuits. Clin Genet. 2006;70(4):295-301.

Bouret SG. Early life origins of obesity: role of hypothalamic programming. J Pediatr Gastroenterol Nutr. 2009;48 Suppl 1:S31-8.

Bouret SG. Organizational actions of metabolic hormones. Front Neuroendocrinol. 2013;34(1):18-26.

Braun K, Champagne FA. Paternal influences on offspring development: behavioural and epigenetic pathways. J Neuroendocrinol. 2014;26(10):697-706.

Bridges RS, Grimm CT. Reversal of morphine disruption of maternal behavior by concurrent treatment with the opiate antagonist naloxone. Science.

1982;218(4568):166-8. 
Bridges RS. Parturition: its role in the long term retention of maternal behavior in the rat. Physiol Behav. 1977;18(3):487-490.

Bridges RS. Retention of rapid onset of maternal behavior during pregnancy in primiparous rats. Behav Biol. 1978;24(1):113-7.

Bridges RS. The role of lactogenic hormones in maternal behavior in female rats. Acta Paediatr Suppl. 1994;397:33-9.

Buonfiglio DC, Ramos-Lobo AM, Freitas VM, Zampieri TT, Nagaishi VS, Magalhães M, Cipolla-Neto J, Cella N, Donato J Jr. Obesity impairs lactation performance in mice by inducing prolactin resistance. Sci Rep. 2016;6:22421.

Bustin SA, Benes V, Garson JA, Hellemans J, Huggett J, Kubista M, et al. The MIQE guidelines: minimum information for publication of quantitative real-time PCR experiments. Clin Chem. 2009;55(4):611-22.

Cabler S, Agarwal A, Flint M, du Plessis SS. Obesity: modern man's fertility nemesis. Asian J Androl. 2010;12(4):480-9.

Calvo SS, Egan JM. The endocrinology of taste receptors. Nat Rev Endocrinol. 2015;11(4):213-27.

Cameron N, Del Corpo A, Diorio J, McAllister K, Sharma S, Meaney MJ. Maternal programming of sexual behavior and hypothalamic-pituitary-gonadal function in the female rat. PLoS One. 2008;3(5):e2210.

Cameron NM, Champagne FA, Parent C, Fish EW, Ozaki-Kuroda K, Meaney MJ. The programming of individual differences in defensive responses and reproductive strategies in the rat through variations in maternal care. Neurosci Biobehav Rev. 2005;29(4-5):843-65.

Campos-Silva P, Furriel A, Costa WS, Sampaio FJ, Gregorio BM. Metabolic and testicular effects of the long-term administration of different high-fat diets in adult rats. Int Braz J Urol. 2015;41(3):569-75.

Carmen GY, Víctor SM. Signalling mechanisms regulating lipolysis. Cell Signal. 2006;18(4):401-8.

Cason AM, Grigson PS. Prior access to a sweet is more protective against cocaine self-administration in female rats than in male rats. Physiol Behav. 2013;112-113:96103.

Celik O, Aydin S, Celik N, Yilmaz M. Peptides: Basic determinants of reproductive functions. Peptides. 2015;72:34-43.

Champagne FA, Francis DD, Mar A, Meaney MJ. Variations in maternal care in the rat as a mediating influence for the effects of environment on development. Physiol Behav. 2003;79(3):359-71. 
Chang GQ, Gaysinskaya V, Karatayev O, Leibowitz SF. Maternal high-fat diet and fetal programming: increased proliferation of hypothalamic peptide-producing neurons that increase risk for overeating and obesity. J Neurosci.

2008;28(46):12107-19.

Chen $\mathrm{H}$, Morris MJ. Differential responses of orexigenic neuropeptides to fasting in offspring of obese mothers. Obesity (Silver Spring). 2009;17(7):1356-62.

Chen H, Simar D, Lambert K, Mercier J, Morris MJ. Maternal and Postnatal Overnutrition Differentially Impact Appetite Regulators and Fuel Metabolism. Endocrinology 2008; 149:5348-356.

Cheung CC, Thornton JE, Nurani SD, Clifton DK, Steiner RA. A reassessment of leptin's role in triggering the onset of puberty in the rat and mouse.

Neuroendocrinology. 2001;74(1):12-21.

Cintra DE, Ropelle ER, Moraes JC, Pauli JR, Morari J, Souza CT, Grimaldi R, Stahl M, Carvalheira JB, Saad MJ, Velloso LA. Unsaturated fatty acids revert diet-induced hypothalamic inflammation in obesity. PLoS One. 2012;7(1):e30571.

Clark JT, Kalra PS, Crowley WR, Kalra SP. Neuropeptide $Y$ and human pancreatic polypeptide stimulate feeding behavior in rats. Endocrinology 1984;115:427-429.

Colman I, Ataullahjan A, Naicker K, Van Lieshout RJ. Birth weight, stress, and symptoms of depression in adolescence: evidence of fetal programming in a national Canadian cohort. Can J Psychiatry. 2012;57(7):422-8.

Connor KL, Vickers MH, Beltrand J, Meaney MJ, Sloboda DM. Nature, nurture or nutrition? Impact of maternal nutrition on maternal care, offspring development and reproductive function. J Physiol. 2012;590(9):2167-80.

Cordero P, Gomez-Uriz AM, Milagro FI, Campion J, Martinez JA. Maternal weight gain induced by an obesogenic diet affects adipose accumulation, liver weight, and insulin homeostasis in the rat offspring depending on the sex. J Endocrinol Invest. 2012;35(11):981-6.

Corona G, Mannucci E, Schulman C, Petrone L, Mansani R, Cilotti A, Balercia G, Chiarini V, Forti G, Maggi M. Psychobiologic correlates of the metabolic syndrome and associated sexual dysfunction. Eur Urol. 2006;50(3):595-604.

Couldrey C, Moitra J, Vinson C, Anver M, Nagashima K, Green J. Adipose tissue: a vital in vivo role in mammary gland development but not differentiation. Dev Dyn. 2002;223(4):459-68.

Cruz-Casallas PE, Nasello AG, Hucke EE, Felicio LF. Dual modulation of male sexual behavior in rats by central prolactin: relationship with in vivo striatal dopaminergic activity. Psychoneuroendocrinology. 1999;24(7):681-93.

Curley JP, Champagne FA. Influence of maternal care on the developing brain: Mechanisms, temporal dynamics and sensitive periods. Front Neuroendocrinol. 
2016;40:52-66.

Das UN. Is obesity an inflammatory condition? Nutrition 2001;17:953-66.

de Graaf C. Effects of snacks on energy intake: an evolutionary perspective. Appetite. 2006;47(1):18-23.

De Mello MA, De Souza CT, Braga LR, Dos Santos JW, Ribeiro IA, Gobatto CA. Glucose tolerance and insulin action in monosodium glutamate (MSG) obese exercise-trained rats. Physiol Chem Phys Med NMR. 2001;33(1):63-71.

Desai M, Han G, Ross MG. Programmed hyperphagia in offspring of obese dams: Altered expression of hypothalamic nutrient sensors, neurogenic factors and epigenetic modulators. Appetite. 2016;99:193-9.

Desai M, Jellyman JK, Han G, Beall M, Lane RH, Ross MG. Maternal obesity and high-fat diet program offspring metabolic syndrome. Am J Obstet Gynecol. $2014 ; 211(3): 237$.

Djiane J, Attig L. Role of leptin during perinatal metabolic programming and obesity. J Physiol Pharmacol. 2008;59 Suppl 1:55-63.

Donath SM, Amir LH. Maternal obesity and initiation and duration of breastfeeding: data from the longitudinal study of Australian children. Matern Child Nutr. 2008;4(3):163-70.

Drewett RF, Statham C, Wakerley JB. A quantitative analysis of the feeding behaviour of suckling rats. Anim Behav. 1974;22(4):907-13.

Dutheil S, Ota KT, Wohleb ES, Rasmussen K, Duman RS. High-Fat Diet Induced Anxiety and Anhedonia: Impact on Brain Homeostasis and Inflammation. Neuropsychopharmacology. 2016;41(7):1874-87.

Dutia R, Meece K, Dighe S, Kim AJ, Wardlaw SL. beta-Endorphin antagonizes the effects of alpha-MSH on food intake and body weight. Endocrinology. 2012;153(9):4246-55.

Elahi MM, Cagampang FR, Mukhtar D, Anthony FW, Ohri SK, Hanson MA. Longterm maternal high-fat feeding from weaning through pregnancy and lactation predisposes offspring to hypertension, raised plasma lipids and fatty liver in mice. $\mathrm{Br}$ J Nutr. 2009;102(4):514-9.

Fan W, Boston BA, Kesterson RA, Hruby VJ, Cone RD. Role of melanocortinergic neurons in feeding and the agouti obesity syndrome. Nature. 1997;385(6612):165-8.

Farooqi IS, Wangensteen T, Collins S, Kimber W, Matarese G, Keogh JM et al. Clinical and molecular genetic spectrum of congenital deficiency of the leptin receptor. N Engl J Med. 2007;356(3):237-47. 
Fernandez CD, Bellentani FF, Fernandes GS, Perobelli JE, Favareto AP, Nascimento AF, Cicogna AC, Kempinas WD. Diet-induced obesity in rats leads to a decrease in sperm motility. Reprod Biol Endocrinol. 2011;9:32. doi: 10.1186/14777827-9-32.

Ferran JL, Puelles L, Rubenstein JL. Molecular codes defining rostrocaudal domains in the embryonic mouse hypothalamus. Front Neuroanat. 2015;9:46.

Figlewicz DP, Bennett JL, Naleid AM, Davis C, Grimm JW. Intraventricular insulin and leptin decrease sucrose self-administration in rats. Physiol Behav. 2006;89(4):611-6.

Flint DJ, Travers MT, Barber MC, Binart N, Kelly PA. Diet-induced obesity impairs mammary development and lactogenesis in murine mammary gland. Am J Physiol Endocrinol Metab. 2005;288(6):E1179-87.

Fukuwatari T, Shibata K, Iguchi K, Saeki T, Iwata A, Tani K, Sugimoto E, Fushiki T. Role of gustation in the recognition of oleate and triolein in anosmic rats. Physiol Behav. 2003;78(4-5):579-83.

Gaillard D, Passilly-Degrace P, Besnard P. Molecular mechanisms of fat preference and overeating. Ann N Y Acad Sci. 2008;1141:163-75.

Gerardin DC, Piffer RC, Garcia PC, Moreira EG, Pereira OC. Effects of maternal exposure to an aromatase inhibitor on sexual behaviour and neurochemical and endocrine aspects of adult male rat. Reprod Fertil Dev. 2008;20(5):557-62.

Ghosh R, Sladek CD. Prolactin modulates oxytocin mRNA during lactation by its action on the hypothalamo-neurohypophyseal axis. Brain Res. 1995;672(1-2):24-8.

Giriko CÁ, Andreoli CA, Mennitti LV, Hosoume LF, Souto Tdos S, Silva AV, Mendesda-Silva C. Delayed physical and neurobehavioral development and increased aggressive and depression-like behaviors in the rat offspring of dams fed a high-fat diet. Int J Dev Neurosci. 2013;31(8):731-9.

Glass MJ, Billington CJ, Levine AS. Naltrexone administered to central nucleus of amygdala or PVN: neural dissociation of diet and energy. Am J Physiol Regul Integr Comp Physiol. 2000;279(1):86-92.

Góes CP1, Sauce B, Peripato AC. Milk ejection in mice LG/J x SM/J. Mamm Genome. 2012;23(11-12):770-9.

Gosnell BA, Levine AS. Reward systems and food intake: role of opioids. Int Journal of Obesity. 2009;33:54-58.

Gradwohl G1, Dierich A, LeMeur M, Guillemot F. Neurogenin3 is required for the development of the four endocrine cell lineages of the pancreas. Proc Natl Acad Sci USA. 2000;97(4):1607-11. 
Grattan DR, Ladyman SR, Augustine RA. Hormonal induction of leptin resistance during pregnancy. Physiol Behav. 2007;91(4):366-74.

Grayson BE, Levasseur PR, Williams SM, Smith MS, Marks DL, Grove KL. Changes in melanocortin expression and inflammatory pathways in fetal offspring of nonhuman primates fed a high-fat diet. Endocrinology 2010;151:1622-32.

Grimm CT, Bridges RS. Opiate regulation of maternal behavior in the rat. Pharmacol Biochem Behav. 1983;19(4):609-16.

Grissom NM, Lyde R, Christ L, Sasson IE, Carlin J, Vitins AP, Simmons RA, Reyes TM. Obesity at conception programs the opioid system in the offspring brain. Neuropsychopharmacology. 2014;39(4):801-10.

Gudelsky GA, Passaro E, Meltzer HY. Delayed activation of tuberoinfundibular dopamine neurons and suppression of prolactin secretion in the rat after morphine administration. J Pharmacol Exp Ther. 1986;236(3):641-5.

Guo F, Jen KL. High-fat feeding during pregnancy and lactation affects offspring metabolism in rats. Physiol Behav. 1995;57(4):681-6.

Gupta N, Shah P, Nayyar S, Misra A. Childhood obesity and the metabolic syndrome in developing countries. Indian J Pediatr. 2013;80 Suppl 1:28-37.

Hâkansson ML1, Brown H, Ghilardi N, Skoda RC, Meister B. Leptin receptor immunoreactivity in chemically defined target neurons of the hypothalamus. $J$ Neurosci. 1998;18(1):559-72.

Hansen M, Flatt T, Aguilaniu H. Reproduction, fat metabolism, and life span: what is the connection? Cell Metab. 2013;17(1):10-9.

Heerwagen MJ, Miller MR, Barbour LA, Friedman JE. Maternal obesity and fetal metabolic programming: a fertile epigenetic soil. Am J Physiol Regul Integr Comp Physiol. 2010;299(3):711-22.

Heinonen I, Rinne P, Ruohonen ST, Ruohonen S, Ahotupa M, Savontaus E. The effects of equal caloric high fat and western diet on metabolic syndrome, oxidative stress and vascular endothelial function in mice. Acta Physiol (Oxf). 2014;211(3):51527.

Hernandez LL, Grayson BE, Yadav E, Seeley RJ, Horseman ND. High fat diet alters lactation outcomes: possible involvement of inflammatory and serotonergic pathways. PLoS One. 2012;7(3):e32598. doi: 10.1371/journal.pone.0032598

Herrera E, Amusquivar E, López-Soldado I, Ortega H. Maternal lipid metabolism and placental lipid transfer. Horm Res 2006;65 Suppl 3:59-64.

Horn CC, Tordoff MG, Friedman MI. Does ingested fat produce satiety? Am J Physiol. 1996;270(4 Pt 2):R761-5. 
Horvath TL, Sarman B, García-Cáceres C, Enriori PJ, Sotonyi P, Shanabrough M et al. Synaptic input organization of the melanocortin system predicts diet-induced hypothalamic reactive gliosis and obesity. Proc Natl Acad Sci USA. 2010;107(33):14875-80.

Howie GJ, Sloboda DM, Kamal T, Vickers MH. Maternal nutritional history predicts obesity in adult offspring independent of postnatal diet. J Physiol. 2009;587(Pt 4):905-15.

Hu H, Xu Y, Liu C, Zhao H, Zhang H, Wang L. Changes in behavior and in brain glucose metabolism in rats after nine weeks on a high fat diet: a randomized controlled trial. Shanghai Arch Psychiatry. 2014;26(3):129-37.

Jacobs S, Teixeira DS, Guilherme C, da Rocha CF, Aranda BC, Reis AR, de Souza MA, Franci CR, Sanvitto GL. The impact of maternal consumption of cafeteria diet on reproductive function in the offspring. Physiol Behav. 2014;129:280-6.

Jans JE, Woodside B. Effects of litter age, litter size, and ambient temperature on the milk ejection reflex in lactating rats. Dev Psychobiol. 1987;20(3):333-44.

Jensen TK, Andersson AM, Jørgensen N, Andersen AG, Carlsen E, Petersen JH, Skakkebæk NE. Body mass index in relation to semen quality and reproductive hormones among 1,558 Danish men. Fertil Steril 2004;82(4):863-870.

Jonas W, Woodside B. Physiological mechanisms, behavioral and psychological factors influencing the transfer of milk from mothers to their young. Horm Behav. 2016;77:167-81.

Kelley AE, Schiltz CA, Landry CF: Neural systems recruited by drug- and foodrelated cues: studies of gene activation in cortico- limbic regions. Physiol Behav 2005;86:11-14.

Kennett JE, McKee DT. Oxytocin: an emerging regulator of prolactin secretion in the female rat. J Neuroendocrinol. 2012;24(3):403-12.

Kinsley CH, Madonia L, Gifford GW, Tureski K, Griffin GR, Lowry C et al. Motherhood improves learning and memory. Nature, 1999;402(6758):137-8.

Kinsley CH. The neuroplastic maternal brain. Horm Behav. 2008;54(1):1-4.

Kiss AC, Woodside B, Felício LF, Anselmo-Franci J, Damasceno DC.Impact of maternal mild hyperglycemia on maternal care and offspring development and behavior of Wistar rats. Physiol Behav. 2012;107(3):292-300.

Kojima S, Catavero C, Rinaman L. Maternal high-fat diet increases independent feeding in pre-weanling rat pups. Physiol Behav. 2016;157:237-45.

Kundakovic M, Champagne FA. Early-life experience, epigenetics, and the developing brain. Neuropsychopharmacology. 2015;40(1):141-53. 
Lagutin OV, Zhu CC, Kobayashi D, Topczewski J, Shimamura K, Puelles L, Russell HR et al. Six3 repression of Wnt signaling in the anterior neuroectoderm is essential for vertebrate forebrain development. Genes Dev. 2003;17(3):368-79.

Lambert KG. The parental brain: transformations and adaptations. Physiol Behav. 2012;107(5):792-800.

Lamont EW, Patterson Z, Rodrigues T, Vallejos O, Blum ID, Abizaid A. Ghrelindeficient mice have fewer orexin cells and reduced cFOS expression in the mesolimbic dopamine pathway under a restricted feeding paradigm. Neuroscience. 2012;218:12-9.

Le Merrer J, Becker J, Befort K, Kieffer BL. Reward processing by the opioid system in the brain. Physiol Rev. 2009;89(4):1379-412.

Leibowitz KL, Chang GQ, Pamy PS, Hill JO, Gayles EC, Leibowitz SF. Weight gain model in prepubertal rats: prediction and phenotyping of obesity-prone animals at normal body weight. Int J Obes (Lond). 2007;31(8):1210-21.

Lemus MB, Bayliss JA, Lockie SH, Santos VV, Reichenbach A, Stark R, Andrews ZB. A stereological analysis of NPY, POMC, Orexin, GFAP astrocyte, and Iba1 microglia cell number and volume in diet-induced obese male mice. Endocrinology. 2015;156(5):1701-13.

Leng G, Meddle SL, Douglas AJ. Oxytocin and the maternal brain. Curr Opin Pharmacol. 2008;8(6):731-4.

Lepe M, Bacardí Gascón M, Castañeda-González LM, Pérez Morales ME, Jiménez Cruz A. Effect of maternal obesity on lactation: systematic review. Nutr Hosp. 2011;26(6):1266-9.

Li D, Olszewski PK, Shi Q, Grace MK, Billington CJ, Kotz CM, Levine AS. Effect of opioid receptor ligands injected into the rostral lateral hypothalamus on c-fos and feeding behavior. Brain Res. 2006;1096(1):120-4.

Li M, Li Q, Gao X. Expression and function of leptin and its receptor in dairy goat mammary gland. J Dairy Res. 2010;77(2):213-9.

Lillycrop KA, Phillips ES, Jackson AA, Hanson MA, Burdge GC. Dietary protein restriction of pregnant rats induces and folic acid supplementation prevents epigenetic modification of hepatic gene expression in the offspring. J Nutr. 2005;135(6):1382-6.

Lincoln DW, Hill A, Wakerley JB. The milk-ejection reflex of the rat: an intermittent function not abolished by surgical levels of anaesthesia. J Endocrinol. 1973;57(3):459-76.

Livak KJ, Schmittgen TD. Analysis of relative gene expression data using real-time quantitative PCR and the 2(-Delta Delta C(T)) Method. Methods. 2001;25(4):402-8. 
Lu F, Kar D, Gruenig N, Zhang ZW, Cousins N, Rodgers HM et al. Rax is a selector gene for mediobasal hypothalamic cell types. J Neurosci. 2013;33(1):259-72.

Ma Q, Kintner C, Anderson DJ. Identification of neurogenin, a vertebrate neuronal determination gene. Cell. 1996;87(1):43-52.

MacKay $\mathrm{H}$, Abizaid A. Embryonic development of the hypothalamic feeding circuitry: Transcriptional, nutritional, and hormonal influences. Mol Metab. 2014;3(9):813-22.

Mackay H, Patterson ZR, Khazall R, Patel S, Tsirlin D, Abizaid A. Organizational effects of perinatal exposure to bisphenol-A and diethylstilbestrol on arcuate nucleus circuitry controlling food intake and energy expenditure in male and female CD-1 mice. Endocrinology. 2013;154(4):1465-75.

Magnusdottir EV, Thorsteinsson T, Thorsteinsdottir S, Maria Heimisdottir M, Olafsdottir K. Persistent organochlorines, sedentary occupation, obesity and human male subfertility. Hum Reprod 2005;20(1):208-215.

Maniam J, Antoniadis CP, Le V, Morris MJ. A diet high in fat and sugar reverses anxiety-like behaviour induced by limited nesting in male rats: Impacts on hippocampal markers. Psychoneuroendocrinology. 2016;68:202-9.

Maolood N, Meister B. Dynorphin in pro-opiomelanocortin neurons of the hypothalamic arcuate nucleus. Neuroscience. 2008;154(3):1121-31.

Marks-Kaufman R. Increased fat consumption induced by morphine administration in rats. Pharmacol Biochem Behav. 1982;16(6):949-55.

Martínez-Ruiz NR, López-Díaz JA, Wall-Medrano A, Jiménez-Castro JA, Angulo O. Oral fat perception is related with body mass index, preference and consumption of high-fat foods. Physiol Behav. 2014;129:36-42.

McNay DE, Pelling M, Claxton S, Guillemot F, Ang SL. Mash1 is required for generic and subtype differentiation of hypothalamic neuroendocrine cells. Mol Endocrinol. 2006;20(7):1623-32.

McNeilly AD, Stewart CA, Sutherland C, Balfour DJ. High fat feeding is associated with stimulation of the hypothalamic-pituitary-adrenal axis and reduced anxiety in the rat. Psychoneuroendocrinology. 2015;52:272-80.

Mebel DM, Wong JC, Dong YJ, Borgland SL. Insulin in the ventral tegmental area reduces hedonic feeding and suppresses dopamine concentration via increased reuptake. Eur J Neurosci 2012;36(3):2336-46.

Mennitti LV, Oliveira JL, Morais CA, Estadella D, Oyama LM, Oller do Nascimento CM, Pisani LP. Type of fatty acids in maternal diets during pregnancy and/or lactation and metabolic consequences of the offspring. J Nutr Biochem. 2015;26(2):99-111. 
Mercer AJ, Stuart RC, Attard CA, Otero-Corchon V, Nillni EA, Low MJ. Temporal changes in nutritional state affect hypothalamic POMC peptide levels independently of leptin in adult male mice. Am J Physiol Endocrinol Metab. 2014;306(8):904-15.

Michalakis K, Mintziori G, Kaprara A, Tarlatzis BC, Goulis DG. The complex interaction between obesity, metabolic syndrome and reproductive axis: a narrative review. Metabolism. 2013;62(4):457-78.

Michaud JL, Rosenquist T, May NR, Fan CM. Development of neuroendocrine lineages requires the bHLH-PAS transcription factor SIM1. Genes Dev. 1998;12(20):3264-75.

Minami S, Frautschy SA, Plotsky PM, Sutton SW, Sarkar DK. Facilitatory role of neuropeptide $Y$ on the onset of puberty: effect of immunoneutralization of neuropeptide $Y$ on the release of luteinizing hormone and luteinizing-hormonereleasing hormone. Neuroendocrinology. 1990;52(1):112-5.

Morris MJ, Beilharz JE, Maniam J, Reichelt AC, Westbrook RF. Why is obesity such a problem in the 21st century? The intersection of palatable food, cues and reward pathways, stress, and cognition. Neurosci Biobehav Rev. 2015;58:36-45.

Morton GJ, Meek TH, Schwartz MW. Neurobiology of food intake in health and disease. Nat Rev Neurosci. 2014;15(6):367-78.

Mountjoy KG. Functions for pro-opiomelanocortin-derived peptides in obesity and diabetes. Biochem J. 2010;428(3):305-24.

Mucellini AB, Goularte JF, de Araujo da Cunha AC, Caceres RC, Noschang C et al. Effects of exposure to a cafeteria diet during gestation and after weaning on the metabolism and body weight of adult male offspring in rats. $\mathrm{Br} \mathrm{J}$ Nutr.

2014;111(8):1499-506.

Muhlhausler BS, Adam CL, Findlay PA, Duffield JA, McMillen IC. Increased maternal nutrition alters development of the appetite-regulating network in the brain. FASEB J. 2006;20(8):1257-9.

Naleid AM, Grace MK, Chimukangara M, Billington CJ, Levine AS. Paraventricular opioids alter intake of high-fat but not high-sucrose diet depending on diet preference in a binge model of feeding. Am J Physiol Regul Integr Comp Physiol. 2007;293(1):99-105.

Nasello AG, Machado C, Bastos JF, Felicio LF. Sudden darkness induces a high activity-low anxiety state in male and female rats. Physiol Behav. 1998;63(3):451-4.

Neri C, Edlow AG. Effects of Maternal Obesity on Fetal Programming: Molecular Approaches. Cold Spring Harb Perspect Med. 2015;6(2).

Neville MC, McFadden TB, Forsyth I. Hormonal regulation of mammary differentiation and milk secretion. J Mammary Gland Biol Neoplasia. 2002;7(1):49-66. 
Ng SF, Lin RC, Laybutt DR, Barres R, Owens JA, Morris MJ. Chronic high-fat diet in fathers programs $\beta$-cell dysfunction in female rat offspring. Nature.

2010;467(7318):963-6.

Nommsen-Rivers LA, Chantry CJ, Peerson JM, Cohen RJ, Dewey KG. Delayed onset of lactogenesis among first-time mothers is related to maternal obesity and factors associated with ineffective breastfeeding. Am J Clin Nutr 2010;92(3):574-84.

Numan M, Fleming AS, Levy F. Mathernal behavior. In: Neil, JD, editor. Knobil and Neill's physiology of reproduction. 3rd ed. San Diego: Elsevier; 2006. p1921-1993.

Numan M, Insel TR. The Neurobiology of Parental Behavior. New York: SpringerVerlag; 2003.

Numan M, Stolzenberg DS. Medial preoptic area interactions with dopamine neural systems in the control of the onset and maintenance of maternal behavior in rats. Front Neuroendocrinol. 2009;30(1):46-64.

Oliveira V, Marinho R, Vitorino D, Santos GA, Moraes JC, Dragano N et al. Diets Containing a-Linolenic ( $\omega 3$ ) or Oleic ( $\omega 9)$ Fatty Acids Rescues Obese Mice From Insulin Resistance. Endocrinology. 2015;156(11):4033-46.

Oliver G, Mailhos A, Wehr R, Copeland NG, Jenkins NA, Gruss P. Six3, a murine homologue of the sine oculis gene, demarcates the most anterior border of the developing neural plate and is expressed during eye development. Development. 1995;121(12):4045-55.

Olszewski PK, Alsiö J, Schiöth HB, Levine AS. Opioids as facilitators of feeding: can any food be rewarding? Physiol Behav. 2011;104(1):105-10.

Ong ZY, Muhlhausler BS. Maternal "junk-food" feeding of rat dams alters food choices and development of the mesolimbic reward pathway in the offspring. FASEB J. 2011;25(7):2167-79.

Ottoni EB. EthoLog 2.2: a tool for the transcription and timing of behavior observation sessions. Behav Res Methods Instrum Comput. 2000;32(3):446-9.

Panchenko PE, Voisin S, Jouin M, Jouneau L, Prézelin A, Lecoutre S et al. Expression of epigenetic machinery genes is sensitive to maternal obesity and weight loss in relation to fetal growth in mice. Clin Epigenetics. 201;8:22.

Parent $\mathrm{Cl}$, Meaney MJ. The influence of natural variations in maternal care on play fighting in the rat. Dev Psychobiol. 2008;50(8):767-76.

Pasquali R, Pelusi C, Genghini S, Cacciari M, Gambineri A: Obesity and reproductive disorders in women. Hum Reprod Update. 2003;9(4):359-372.

Paxinos G, Watson C. The rat brain in stereotaxic coordinates. 4th ed. San Diego: Academic Press; 1998. 
Peleg-Raibstein D, Luca E, Wolfrum C. Maternal high-fat diet in mice programs emotional behavior in adulthood. Behav Brain Res. 2012;233(2):398-404.

Pelling M, Anthwal N, McNay D, Gradwohl G, Leiter AB, Guillemot F, Ang SL. Differential requirements for neurogenin 3 in the development of POMC and NPY neurons in the hypothalamus. Dev Biol. 2011;349(2):406-16.

Perello M, Raingo J. Leptin activates oxytocin neurons of the hypothalamic paraventricular nucleus in both control and diet-induced obese rodents. PLoS One. 2013;8(3):e59625.

Pitsavos C, Panagiotakos DB, Papageorgiou C, Tsetsekou E, Soldatos C, Stefanadis C. Anxiety in relation to inflammation and coagulation markers, among healthy adults: the ATTICA study. Atherosclerosis 2006;185:320-6.

Poston, L. Gestational weight gain: influences on the long-term health of the child. Curr Opin Clin Nutr Metab Care. 2012;15(3):252-7.

Purcell RH, Sun B, Pass LL, Power ML, Moran TH, Tamashiro KL. Maternal stress and high-fat diet effect on maternal behavior, milk composition, and pup ingestive behavior. Physiol Behav. 2011;104(3):474-9.

Rasmussen KM, Kjolhede CL. Prepregnant overweight and obesity diminish the prolactin response to suckling in the first week postpartum. Pediatrics. 2004;113(5):e465-71.

Ray GT, Croen LA, Habel LA. Mothers of children diagnosed with attentiondeficit/hyperactivity disorder: health conditions and medical care utilization in periods before and after birth of the child. Med Care 2009;47:105-14.

Rivera HM, Christiansen KJ, Sullivan EL. The role of maternal obesity in the risk of neuropsychiatric disorders. Front Neurosci. 2015;9:194.

Rodriguez A. Maternal pre-pregnancy obesity and risk for inattention and negative emotionality in children. J Child Psychol Psychiatry. 2010;51(2):134-43.

Rosenblatt JS. Psychobiology of maternal behavior: contribution to the clinical understanding of maternal behavior among humans. Acta Paediatr Suppl. 1994;397:3-8.

Ross MG, Desai M. Developmental programming of appetite/satiety. Ann Nutr Metab. 2014;64 Suppl 1:36-44.

Rossi M, Kim MS, Morgan DG, Small CJ, Edwards CM, Sunter D et al. A C-terminal fragment of Agouti-related protein increases feeding and antagonizes the effect of alpha-melanocyte stimulating hormone in vivo. Endocrinology. 1998;139:4428-4431.

Russell JA, Coombes JE, Leng G, Bicknell RJ. Morphine tolerance and inhibition of oxytocin secretion by kappa-opioids acting on the rat neurohypophysis. J Physiol. 1993;469:365-86. 
Russell JA, Leng G, Douglas AJ. The magnocellular oxytocin system, the fount of maternity: adaptations in pregnancy. Front Neuroendocrinol. 2003;24(1):27-61.

Saben JL, Bales ES, Jackman MR, Orlicky D, MacLean PS, McManaman JL. Maternal obesity reduces milk lipid production in lactating mice by inhibiting acetylCoA carboxylase and impairing fatty acid synthesis. PLoS One. 2014;9(5):e98066.

Sacks DA, Liu Al, Wolde-Tsadik G, Amini SB, Huston-Presley L, Catalano PM. What proportion of birth weight is attributable to maternal glucose among infants of diabetic women? Am J Ob Gyn 2006;194(2):501-7.

Sahu A, Phelps CP, White JD, Crowley WR, Kalra SP, Kalra PS. Steroidal regulation of hypothalamic neuropeptide $Y$ release and gene expression. Endocrinology. 1992;130(6):3331-6.

Sakar Y, Duca FA, Langelier B, Devime F, Blottiere H, Delorme C, et al. Impact of high-fat feeding on basic helix-loop-helix transcription factors controlling enteroendocrine cell differentiation. Int J Obes (Lond). 2014;38(11):1440-8.

Samuelsson AM, Matthews PA, Argenton M et al. Diet-induced obesity in female mice leads to offspring hyperphagia, adiposity, hypertension, and insulin resistance: a novel murine model of developmental programming. Hypertension. 2008;51(2):383392.

Sánchez J, Priego T, García AP, Llopis M, Palou M, Picó C, Palou A. Maternal supplementation with an excess of different fat sources during pregnancy and lactation differentially affects feeding behavior in offspring: putative role of the leptin system. Mol Nutr Food Res. 2012;56(11):1715-28.

Sánchez-Garrido MA, Castellano JM, Ruiz-Pino F, Garcia-Galiano D, ManfrediLozano M, Leon S, Romero-Ruiz A, Diéguez C, Pinilla L, Tena-Sempere M. Metabolic programming of puberty: sexually dimorphic responses to early nutritional challenges. Endocrinology. 2013;154(9):3387-400.

Sasaki A, de Vega WC, St-Cyr S, Pan P, McGowan PO. Perinatal high fat diet alters glucocorticoid signaling and anxiety behavior in adulthood. Neuroscience. 2013;240:1-12.

Scerbo MJ, Freire-Regatillo A, Cisternas CD, Brunotto M, Arevalo MA, GarciaSegura LM, Cambiasso MJ. Neurogenin 3 mediates sex chromosome effects on the generation of sex differences in hypothalamic neuronal development. Front Cell Neurosci. 2014;8:188.

Schmittgen TD, Livak KJ. Analyzing real-time PCR data by the comparative $\mathrm{C}(\mathrm{T})$ method. Nat Protoc. 2008;3(6):1101-8.

Schonhoff SE, Giel-Moloney M, Leiter AB. Neurogenin 3-expressing progenitor cells in the gastrointestinal tract differentiate into both endocrine and non-endocrine cell types. Dev Biol. 2004;270(2):443-54. 
Schwartz GJ, Fu J, Astarita G, Li X, Gaetani S, Campolongo P, Cuomo V, Piomelli D. The lipid messenger OEA links dietary fat intake to satiety. Cell Metab.

2008;8(4):281-8.

Schwartz MW1, Woods SC, Porte D Jr, Seeley RJ, Baskin DG. Central nervous system control of food intake. Nature. 2000;404(6778):661-71.

Sharma S, Fernandes MF, Fulton S. Adaptations in brain reward circuitry underlie palatable food cravings and anxiety induced by high-fat diet withdrawal. Int $\mathrm{J}$ Obes (Lond). 2013;37(9):1183-91.

Sheffer-Babila S1, Sun Y, Israel DD, Liu SM, Neal-Perry G, Chua SC Jr. Agoutirelated peptide plays a critical role in leptin's effects on female puberty and reproduction. Am J Physiol Endocrinol Metab. 2013;305(12):1512-20.

Shi H, Seeley RJ, Clegg DJ. Sexual differences in the control of energy homeostasis. Front Neuroendocrinol. 2009;30(3):396-404.

Shi H, Strader AD, Sorrell JE, Chambers JB, Woods SC, Seeley RJ. Sexually different actions of leptin in proopiomelanocortin neurons to regulate glucose homeostasis. Am J Physiol Endocrinol Metab. 2008;294(3):630-9.

Shimogori T, Lee DA, Miranda-Angulo A, Yang Y, Wang H, Jiang L, Yoshida AC, Kataoka A, Mashiko H, Avetisyan M, Qi L, Qian J, Blackshaw S. A genomic atlas of mouse hypothalamic development. Nat Neurosci. 2010;13(6):767-75.

Sipols AJ, Bayer J, Bennett R, Figlewicz DP. Intraventricular insulin decreases opioid-mediated sucrose intake in rats. Peptides. 2002;23(12):2181-7.

Sladek CD, Stevens W, Song Z, Johnson GC, MacLean PS. The "metabolic sensor" function of rat supraoptic oxytocin and vasopressin neurons is attenuated during lactation but not in diet-induced obesity. Am J Physiol Regul Integr Comp Physiol. 2016;310(4):337-45.

Sloboda DM, Howie GJ, Pleasants A, Gluckman PD, Vickers MH. Pre- and postnatal nutritional histories influence reproductive maturation and ovarian function in the rat. PLoS One. 2009;4(8):e6744.

Smart JL, Dobbing J. Vulnerability of developing brain. II. Effects of early nutritional deprivation on reflex ontogeny and development of behaviour in the rat. Brain Res. 1971;28(1):85-95.

Smith SS, Neuringer M, Ojeda SR. Essential fatty acid deficiency delays the onset of puberty in the female rat. Endocrinology. 1989;125(3):1650-9.

Soliman A, De Sanctis V, Elalaily R. Nutrition and pubertal development. Indian J Endocrinol Metab. 2014;18 Suppl $1: 39-47$. 
Sommer L, Ma Q, Anderson DJ. Neurogenins, a novel family of atonal-related bHLH transcription factors, are putative mammalian neuronal determination genes that reveal progenitor cell heterogeneity in the developing CNS and PNS. Mol Cell Neurosci. 1996;8(4):221-41.

Song Z, Levin BE, Stevens W, Sladek CD. Supraoptic oxytocin and vasopressin neurons function as glucose and metabolic sensors. Am J Physiol Regul Integr Comp Physiol. 2014;306(7):R447-56.

Soulimane-Mokhtari NA, Guermouche B, Yessoufou A, Saker M, Moutairou K, Hichami $A$ et al. Modulation of lipid metabolism by $n-3$ polyunsaturated fatty acids in gestational diabetic rats and their macrosomic offspring. Clin Sci (Lond). 2005;109(3):287-95.

Stern JM, Johnson SK. Ventral somatosensory determinants of nursing behavior in Norway rats. Physiol Behav. 1990;47(5):993-1011.

Strakovsky RS, Zhang X, Zhou D, Pan YX. Gestational high fat diet programs hepatic phosphoenolpyruvate carboxykinase gene expression and histone modification in neonatal offspring rats. J Physiol. 2011;589(Pt 11):2707-17.

Sullivan EL, Grayson B, Takahashi D, Robertson N, Maier A, Bethea CL et al. Chronic consumption of a high-fat diet during pregnancy causes perturbations in the serotonergic system and increased anxiety-like behavior in nonhuman primate offspring. J Neurosci. 2010;30(10):3826-30.

Sullivan EL, Nousen EK, Chamlou KA. Maternal high fat diet consumption during the perinatal period programs offspring behavior. Physiol Behav. 2014;123:236-42.

Sullivan EL, Riper KM, Lockard R, Valleau JC. Maternal high-fat diet programming of the neuroendocrine system and behavior. Horm Behav. 2015;76:153-61.

Sullivan EL, Smith MS, Grove KL. Perinatal exposure to high-fat diet programs energy balance, metabolism and behavior in adulthood. Neuroendocrinology. 2011;93(1):1-8.

Sumner BE, Coombes JE, Pumford KM, Russell JA. Opioid receptor subtypes in the supraoptic nucleus and posterior pituitary gland of morphine-tolerant rats.

Neuroscience. 1990;37(3):635-45.

Sutton SW, Mitsugi N, Plotsky PM, Sarkar DK. Neuropeptide Y (NPY): a possible role in the initiation of puberty. Endocrinology. 1988;123(4):2152-4.

Svennersten-Sjaunja K, Olsson K. Endocrinology of milk production. Domest Anim Endocrinol. 2005;29(2):241-58.

Taha SA. Preference or fat? Revisiting opioid effects on food intake. Physiol Behav. 2010;100(5):429-37.

Tai MM. A mathematical model for the determination of total area under glucose tolerance and other metabolic curves. Diabetes Care. 1994;17(2):152-154. 
Takase K, Tsuneoka Y, Oda S, Kuroda M, Funato H. High-fat diet feeding alters olfactory-, social-, and reward-related behaviors of mice independent of obesity. Obesity (Silver Spring). 2016;24(4):886-94.

Tamashiro KLK, Terrillion CE, Hyun J, Koenig JI, Moran TH. Prenatal Stress or HighFat Diet increases Susceptibility to Diet-Induced Obesity in Rat Offspring. Diabetes 2009; 58:1116-1125.

Tancin V, KraetzI WD, Schams D. Effects of morphine and naloxone on the release oxytocin and on milk ejection in dairy cows. J Dairy Res. 2000;67(1):13-20.

Tavakoli-Nezhad M1, Arbogast LA. Mu and kappa opioid receptor expression in the mediobasal hypothalamus and effectiveness of selective antagonists on prolactin release during lactation. Neuroscience. 2010;166(2):359-67.

Teegarden SL, Scott AN, Bale TL. Early life exposure to a high fat diet promotes long-term changes in dietary preferences and central reward signaling. Neuroscience. 2009;162(4):924-32.

Teodorov E, Bernardi MM, Ferrari MF, Fior-Chadi DR, Felicio LF. Plasticity of opioid receptors in the female periaqueductal gray: multiparity-induced increase in the activity of genes encoding for mu and kappa receptors and a post-translational decrease in delta receptor expression. J Mol Neurosci. 2011;43(2):175-81.

Terkel J, Bridges RS, Sawyer $\mathrm{CH}$. Effects of transecting lateral neural connections of the medial preoptic area on maternal behavior in the rat: nest building, pup retrieval and prolactin secretion. Brain Res. 1979;169(2):369-80.

Theodosis DT, Koksma JJ, Trailin A, Langle SL, Piet R, Lodder JC, Timmerman J, Mansvelder H, Poulain DA, Oliet SH, Brussaard AB. Oxytocin and estrogen promote rapid formation of functional GABA synapses in the adult supraoptic nucleus. Mol Cell Neurosci. 2006;31(4):785-94.

Thornburg KL, Bagby SP, Giraud GD. Maternal adaptation to pregnancy. In: Neill JD, Plant TM, Challis JRG, Krestser DM, Richards JS, Wassarman PM, editors . Knobil and Neill's Physiology of Reproduction. $3^{\text {rd }}$ ed. San Diego: Elsevier; 2006. vol. 2, p. 2899-2923.

Tietz N. Textbook of Clinical Chemistry. New York: Saunders; 1986. p486.

Treesukosol Y, Sun B, Moghadam AA, Liang NC, Tamashiro KL, Moran TH. Maternal high-fat diet during pregnancy and lactation reduces the appetitive behavioral component in female offspring tested in a brief-access taste procedure. Am J Physiol Regul Integr Comp Physiol. 2014;306(7):499-509.

Trottier G, Koski KG, Brun T, Toufexis DJ, Richard D, Walker CD. Increased fat intake during lactation modifies hypothalamic-pituitary-adrenal responsiveness in developing rat pups: a possible role for leptin. Endocrinology. 1998;139(9):3704-11. 
Tso P, Liu M. Ingested fat and satiety. Physiol Behav. 2004;81(2):275-87.

Tsuruta M, Kawada T, Fukuwatari T, Fushiki T. The orosensory recognition of longchain fatty acids in rats. Physiol Behav. 1999;66(2):285-8.

Tuominen L, Tuulari J, Karlsson H, Hirvonen J, Helin S, Salminen P et al. Aberrant mesolimbic dopamine-opiate interaction in obesity. Neuroimage. 2015;122:80-6.

Ugarte A, Eguibar JR, Cortés Mdel C, León-Chávez BA, Melo Al. Comparative analysis of maternal care in the high-yawning $(\mathrm{HY})$ and low-yawning $(\mathrm{LY})$ sublines from Sprague-Dawley rats. Dev Psychobiol. 2011;53(2):105-17.

van den Heuvel JK, van Rozen AJ, Adan RA, la Fleur SE. An overview on how components of the melanocortin system respond to different high energy diets. Eur $\mathrm{J}$ Pharmacol. 2011;660(1):207-12.

Van Lieshout RJ1, Robinson M, Boyle MH. Maternal pre-pregnancy body mass index and internalizing and externalizing problems in offspring. Can J Psychiatry. 2013;58(3):151-9.

Velmurugan S, Russell JA, Leng G. Systemic leptin increases the electrical activity of supraoptic nucleus oxytocin neurones in virgin and late pregnant rats. $J$ Neuroendocrinol. 2013;25(4):383-90.

Viscarra JA, Ortiz RM. Cellular mechanisms regulating fuel metabolism in mammals: role of adipose tissue and lipids during prolonged food deprivation. Metabolism. 2013;62(7):889-97.

Vogt MC, Paeger L, Hess S, Steculorum SM, Awazawa M, Hampel B et al. Neonatal insulin action impairs hypothalamic neurocircuit formation in response to maternal high-fat feeding. Cell. 2014;156(3):495-509.

Volpato AM, Schultz A, Magalhães-da-Costa E, Correia ML, Aguila MB, Mandarimde-Lacerda CA. Maternal High-Fat Diet Programs for Metabolic Disturbances in Offspring despite Leptin Sensitivity. Neuroendocrinology. 2012;96(4):272-84.

Vucetic Z, Kimmel J, Totoki K, Hollenbeck E, Reyes TM. Maternal high-fat diet alters methylation and gene expression of dopamine and opioid-related genes.

Endocrinology. 2010;151(10):4756-4764.

Walf AA, Frye CA. The use of the elevated plus maze as an assay of anxiety-related behavior in rodents. Nat Protoc. 2007;2(2):322-8.

Walker CD. Maternal touch and feed as critical regulators of behavioral and stress responses in the offspring. Dev Psychobiol. 2010;52:638-50.

Wang $\mathrm{H}$, Storlien LH, Huang XF. Influence of dietary fats on c-Fos-like immunoreactivity in mouse hypothalamus. Brain Res. 1999;843(1-2):184-92. 
Weaver IC, Meaney MJ, Szyf M. Maternal care effects on the hippocampal transcriptome and anxiety-mediated behaviors in the offspring that are reversible in adulthood. Proc Natl Acad Sci USA. 2006;103:3480-5.

Wells JC. The thrifty phenotype as an adaptive maternal effect. Biol Rev Camb Philos Soc. 2007;82(1):143-72.

White CL, Purpera MN, Morrison CD. Maternal obesity is necessary for programming effect of high-fat diet on offspring. Am J Physiol Regul Integr Comp Physiol. 2009;296(5):1464-72.

Woodside B, Augustine R, Naef L, Ladyman S, Grattan D. Role of prolactin in the metabolic adaptations to pregnancy and lactation. In: Bridges RS, editor. The Parental Brain. San Diego: Elsevier; 2008. p. 249-268.

Woodside B, Budin R, Wellman MK, Abizaid A. Many mouths to feed: the control of food intake during lactation. Front Neuroendocrinol. 2012;33(3):301-14.

Woolley JD, Lee BS, Fields HL. Nucleus accumbens opioids regulate flavor-based preferences in food consumption. Neuroscience. 2006;143(1):309-17.

Woolley JD, Lee BS, Kim B, Fields HL. Opposing effects of intra-nucleus accumbens mu and kappa opioid agonists on sensory specific satiety. Neuroscience.

2007;146(4):1445-52.

World Health Organization (WHO). Obesity and overweigth. Geneva: World Health Organization; 2015. [acesso em 2016 Maio 12] Disponível em:

http://www.who.int/mediacentre/factsheets/fs311/en/index.html

Wright DM. Evidence for a spinal site at which opioids may act to inhibit the milkejection reflex. J Endocrinol. 1985;106(3):401-7.

Yang KF, Cai W, Xu JL, Shi W. Maternal high-fat diet programs Wnt genes through histone modification in the liver of neonatal rats. J Mol Endocrinol 2012;49(2):10714.

Zemdegs J, Quesseveur G, Jarriault D, Pénicaud L, Fioramonti X, Guiard BP. High fat diet-induced metabolic disorders impairs serotonergic function and anxiety-like behaviours in mice. Br J Pharmacol. 2015. doi: 10.1111/bph.13343.

Zimberknopf E, Xavier GF, Kinsley CH, Felicio LF. Prior parity positively regulates learning and memory in young and middle-aged rats. Comp Med. 2011;61(4):366-77. 